\title{
Osteocalcin: posttranslational gamma carboxylation of a unique vitamin K-dependent protein
}

Citation for published version (APA):

Houben, R. J. T. J. (1999). Osteocalcin: posttranslational gamma carboxylation of a unique vitamin Kdependent protein. [Doctoral Thesis, Maastricht University]. Universiteit Maastricht. https://doi.org/10.26481/dis.19991216rh

Document status and date:

Published: 01/01/1999

DOI:

10.26481/dis.19991216rh

Document Version:

Publisher's PDF, also known as Version of record

\section{Please check the document version of this publication:}

- A submitted manuscript is the version of the article upon submission and before peer-review. There can be important differences between the submitted version and the official published version of record. People interested in the research are advised to contact the author for the final version of the publication, or visit the DOI to the publisher's website.

- The final author version and the galley proof are versions of the publication after peer review.

- The final published version features the final layout of the paper including the volume, issue and page numbers.

Link to publication

\footnotetext{
General rights rights.

- You may freely distribute the URL identifying the publication in the public portal. please follow below link for the End User Agreement:

www.umlib.nl/taverne-license

Take down policy

If you believe that this document breaches copyright please contact us at:

repository@maastrichtuniversity.nl

providing details and we will investigate your claim.
}

Copyright and moral rights for the publications made accessible in the public portal are retained by the authors and/or other copyright owners and it is a condition of accessing publications that users recognise and abide by the legal requirements associated with these

- Users may download and print one copy of any publication from the public portal for the purpose of private study or research.

- You may not further distribute the material or use it for any profit-making activity or commercial gain

If the publication is distributed under the terms of Article $25 \mathrm{fa}$ of the Dutch Copyright Act, indicated by the "Taverne" license above, 
Osteocalcin:

Posttranslational gamma carboxylation of a unique vitamin K-dependent protein 
Omslag: Roger J.T.J. Houben

Druk: Datawyse | Universitaire Pers Maastricht

ISBN 9052782571

(O) Roger J.T.J. Houben, Amersfoort 4999 


\title{
Osteocalcin: Posttranslational gamma carboxylation of a unique vitamin K-dependent protein
}

\author{
Proefschrift \\ ter verkrijging van de graad van doctor \\ aan de Universiteit Maastricht, \\ op gezag van de Rector Magnificus, \\ Prof. Dr. A.C. Nieuwenhuijzen Kruseman \\ volgens het besluit van het College van Decanen, \\ in het openbaar te verdedigen \\ op donderdag 16 december 1999 om 16.00 uur \\ door
}

Roger Johannes Theresia Josephina Houben

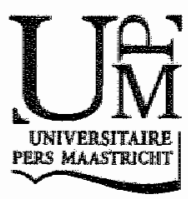




\section{Promotores:}

Prof. Dr. H.C. Hemker

Prof. Dr. F.C.S. Ramaekers

Co-promotor:

Dr. C. Vermeer

\section{Beoordelingscommissie:}

Prof. Dr. J. Rosing (voorzitter)

Prof. Dr. T.W.A. de Bruin

Prof. Dr. M.J.A.P. Daemen

Prof. Dr. J.G.R. De Mey

Dr. G.J.J.M. van Eys

This thesis was financially supported by Roche Nederland BV, Division Vitamins \& Fine Chemicals; BIOzymTC BV (Landgraat, The Netherlands) and Beun de Ronde / Centraal Magazin (Abcoude, The Netherlands). Financial support by Mia and Frans Houben (Helvoirt, The Neherlands) is gratefully achowledged. 
What is man, when you come to think upon him, but a minutely set, ingenious machine for turning, with infinite antulness, the red wine of Shraz into unine?

Isak Dinesen (Karen Blixen) Seven Gothic Tales (1934) "The Dreamers"

Voor Jacquir,

Voor min ouders en Enwin. 



\section{Contents}

Abbreviations

page

8

Chapter 1 General Introduction

Chapter 2 The Requirement of Recombinant Osteocalcin: Possibilities. Limitations and In Vitro Carboxylation

\$2.1 The Requirement for Osteocalcin Protein Standards 53 Scand J Clin Lab fwosi 1997, 57 (suppl 227) 100-104

$\$ 2.2$ Cloning and Expression of Osteocalcin Using Escherichia Coli as a Host

\$2.3 Various in Vitro Vitamin K-Dependent Gamma-Carboxylating Tissues

Merhods Enzymol $4997,282,359-368$

Chapter 3 The Role of the Propeptide and Gamma-Glutamic Acid Domain of Factor IX For In Vitro Carboxylation by the Vitamin K-Dependent

Carboxylase

Biochemistry $1998,37,13262-13268$

Chapter 4 Osteocalcin Binds Tightly to the Gamma-Glutamyl Carboxylase at a Site Distinct From That of the Other Known Vitamin K-Dependent Proteins

Biochem J 1999, 341, 265-269

Chapter 5 Osteocalcin Specific Binding Site on the Vitamin K. Dependent Gamma-Glutamy/ Carboxylase

Biochem \& Submitted

Chapter 6 The Composition of the Vitamin K-Dependent Gamma-Giltamyl

Carboxylase Binding Domain on Osteocalcin

Biachem I Submitted

Chapter 7 Summary, Conclusions and Discussion 


\section{Abbreviations}

bEELOMe

$\mathrm{BGP}$

CHAPS

$d-.$.

DHFR

DTT

ELISA

FII

FIX

FIXproGLA41

FIXproGLA46

FIXproNonGLA

FLEEL

FLEEV

FVII

$\mathbb{F} X$

$Y$-CRS

Gla

Glu

HPLC

$K_{1}$
The tripeptide boc-glutamate-glutamate-leucine-methyl Bone Gla protein

3-[(3-cholamidopropyl)dimethylammonio]-1-propanesulfonate

Refers to a descarboxy protein

Dihydroxy folate reductase

Dithiothreitol

Enzyme-linked immunosorbent assay

Prothrombin

Coagulation factor $\mathrm{XX}$

59 Amino acid peptide containing the human factor $1 X$ propeptide and first 41 residues of factor IX gla domain (Sequence -18 to 41 )

64 Amino acid peptide containing the human factor IX propeptide and the entire gla domain and hydrophobic stack sequence (Sequence -18 to 46 )

52 Amino acid peptide containing the factor IX propeptide followed by a 34 amino acid non-gla domain sequence The pentapeptide phenylalanine-leucine-glutamate-glutamateleucine

The pentapeptide phenylalanine-leucine-glutamate-glutamatevaline

Coagulation factor $V \| l$

Coagulation factor $X$

Gamma glutamyl carboxylase recognition sequence

Gamma-carboxyglutamic acid

Glutamic acid

High performance liquid chromatography

Phylloquinone 
$K_{2}$

$\mathrm{K}_{3}$

$\mathrm{kDa}$

$\mathrm{KH}_{2}$

$\mathrm{KO}$

MBP

MGP

MK-n

MOPS

MW

NAD(P)H

$\left(\mathrm{NH}_{4}\right)_{2} \mathrm{SO}_{4}$

$\mathrm{OC}$

PAA

PAGE

PC

Pro

Pro(Glu) 10

ProFIX

Pro ${ }^{\text {FIX }}$

ProFIX(GLA)

ProFIX19

ProlX-59 Q/S

Pro ${ }^{\circ}$

ProPT $-28 \mathrm{~F} / \mathrm{A}$
Groupname for Menaquinones

Menadiane

KilloDalton

Vitamin K hydroquinone

Vitamin $K 2,3$ epoxide

Maltose binding protein

Matrix Gla protein

Menaquinones

3-(N-morpholino)propame-sulfonic acid

Molecular weight

Nicotinamide adenine dinucleotide (phosphate) reduced form

Ammonium sulphate

Osteocalcin

Polyacryl amide

Polyacryl amide gel electrophoresis

Phosphatidylcholine

Propeptide

The prosequence of human prothrombin covalently bound to ten Glu residues

Full length uncarboxylated human factor $\mathrm{X}$ with the propeptide still attached

Propeptide of human coagulation factor $\mathrm{X}$ precursor molecule Full length carboxylated human factor IX with the propeptide still attached

AVFLDHENANKILNRPKRY

The propeptide and Gla-domain of human descarboxyfactor IX, in which $R^{-4}$ has been replaced by $Q$, and $R^{-1}$ has been replaced by $S$

Propeptide of human osteocallin precursor molecule

The prosequence of human descarboxyprothombin with the first 
10 residues of the Gla-domain, in which $F^{-16}$ has been replaced by $A$

RER

Rough endoplasmic reticulum

S-MeTPT

Methylated tripeptide

SDS

Sodium dodecyl sulphate

TCA

Trichloroacetic acid

$4 \mathrm{COC}$

Undercarboxylated osteocalcin not bound to hydroxyapatite 


\section{Chapter 1}

GENERAL INTRODUCTION 



\section{Vitamin $\mathrm{K}$ and its antagonists in a historical perspective}

The first reports about the possibility of a new and so far unknown vitamin involved in blood coagulation were made by the Danish biochemist Henrik Dam who studied the effect of a cholesterol depleted diet on chickens '. Cholesterol was removed from the chicken feed by ether-extraction after which the food was supplemented with the other known essential fat-soluble components and vitamins. After several weeks, the chickens showed spontaneous bleedings, delayed blood-clotting, and finally died within a month. Administration of purified cholesterol and/ or extra vitamins to the diet did not result in abrogation of the bleeding tendency. Eventually, in 1935, Dam was able to prove that a deficiency of a yet unknown fat soluble vitamin was the sole cause of this hemorrhagic disease. He called this fat-soluble, anti-hemorrhagic vitamin "Vitamin K", after the first letter of the Danisch word Koagulation?

The observations made by Henrik Dam had a remarkable similarity with those made in cattle in the early $1920^{\circ} \mathrm{s}^{3}$. It turned out that cattle fed on improperly cured sweet clover hay suffered from spontaneous bleedings comparable to those observed in vitamin $\mathrm{K}$ deficient chickens. The component in the hay responsible for these phenomenons was identified as 3,3'-methylene-bis-(4 - hydroxycoumarin) and called dicoumarol (figure 1) ${ }^{4,5}$. This component is also present in fresh sweet clover where it is chemically bound, and thus inactive. However, after dry-storage of the hay it may be liberated and become active. Additional research showed that dicoumarol and some of its derivatives act as an antagonist of vitamin $\mathrm{K}$ action. Presently they are used as pharmacological agents for anticoagulation and as rodenticides. In humans coumarin derivatives serve for the prevention of thrombotic events through their inhibition of the hepatic synthesis of the coagulation factors prothrombin, VII, $I X$ and $X$. Since during recent years a number of vitamin $\mathrm{K}$-dependent proteins have been discovered with regulatory functions in other physiological processes than blood coagulation ${ }^{6-11}$; unexpected side-effects of anticoagulant therapy cannot be excluded. An example of such side-effects is the fetal warfarin embryopathy in which severe bone / cartilage malformations occur in the developing fetus resulting in abnormal cartilage calcification, nasal hypoplasia and abnormalities of the spine ${ }^{12}$. 
<smiles>CCC(c1ccccc1)c1c(O)c2ccccc2oc1=O</smiles>

phenprocoumon<smiles>CC(=O)CC(c1ccccc1)c1c(O)c2ccccc2oc1=O</smiles>

wartarin<smiles>O=c1oc2ccccc2c(O)c1Cc1c(O)c2ccccc2oc1=O</smiles>

dicoumarol

Figure 1: $\quad$ Structure of several vitamin $K$ antagonists

\section{Various forms of vitamin $K$}

Vitamin $K$ is a generic term for a group of distinguishable compounds that possess: "vitamin $K$ activity" and are called phylloquinone $\left(K_{1}\right)$, menaquinones $\left(K_{2}\right)$ and menadione $\left(K_{3}\right)$. Phylloquinone and menaquinones are naturally occurring vitamers, whereas menadione is a synthetic analogue of $K_{\text {. }}$

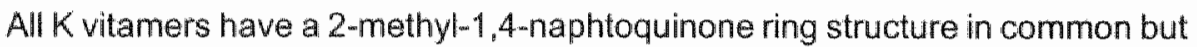
they differ in the length and degree of saturation of an aliphatic side chain. located at the 3-position. Phylloquinone is produced by green algae and in green leafy plants, where it functions as an electron carrier in chloroplasts ${ }^{13}$. Its phytyl side chain consists of 4 isoprenoid residues of which the first one is unsaturated.

Menaquinones are products of bacterial metabolism; they are generated in mammallian intestines and also occur in fermented food products such as sauerkraut, 
cheese, curd-cheese and natto (fermented soy beans). The various menaquinones differ in their phytyl side chain length which may vary from 4 up to 13 isoprenoid units. According to the generally accepted nomenclature menaquinones are designated as MK- $n$, where $n$ stands for the number of isoprenoid units in the side chain. At increasing side chain length the hydrophobicity of the menaquinones will increase proportionally.

Menadione, or 2-methyl-1,4-naphtoquinone, is a synthetical product and does not occur in nature. Menadione is water soluble, and has to be metabolized in wivo before it obtaining vitamin $\mathrm{K}$ activity. As a therapeutical agent, however, menadione is not applied any more in humans because of its possible adverse side effects such as haemolysis ${ }^{14.15}$. Several authors have reported in vitro suppression of tumor cell growth by menadione ${ }^{16-20}$. Menadione is currently used on a large scale as a supplement in<smiles>CC(C)=CCC1=C(C)C(=O)c2ccccc2C1=O</smiles>

\section{Vitam in $\mathrm{K} 1$}<smiles>CC=CCC1=C(C)C(=O)c2ccccc2C1=O</smiles>

Menaquinon $-n$<smiles>CC1=CC(=O)c2ccccc2C1=O</smiles>

Menadion

Figure 2: $\quad$ Chemical structures of witamin $K_{,}$(phyloquinone), menaquinone (vitamin $K_{2}$ ) and menadione (vitamin $K_{3}$ ) 
animal food (figure 2).

\section{Functions of vitamin $K$}

Vitamin $K$ is ínvolved as a co-factor in the post-translational processing of proteins. It was allready postulated in 1963 by Hemker et al ${ }^{24}$ that the blood plasma of patients receiving anticoagulant therapy contained an abnormal form of prothrombin (factor II) which they called preprothrombin, the so-called precursor molecule of the active prothrombin. This hypothesis was supported by both Ganrot ${ }^{22}$ and Josso 23 who demonstrated a protein in plasma of anticoagulated patients which behaved immunochemically like prothrombin but immunoelectrophoretically showed differences when compared to prothrombin. Moreover, it remained inactive in an in vitro coagulation assay because it was unable to bind $\mathrm{Ca}^{2+}$ ions. However, it took untill 1974 before several groups reported independently ${ }^{24-26}$ that these so called PIVKA's (Protein Induced by Vitamin $\underline{K}$ Antagonists) were lacking an uncommon amino acid: $\gamma$ carboxyglutamic acid (Gla). The absence of this highly negatively charged amino acid was the reason that PIVKA-prothrombin (PIVKA-II) was incapable of binding $\mathrm{Ca}^{2+}$ Hons.
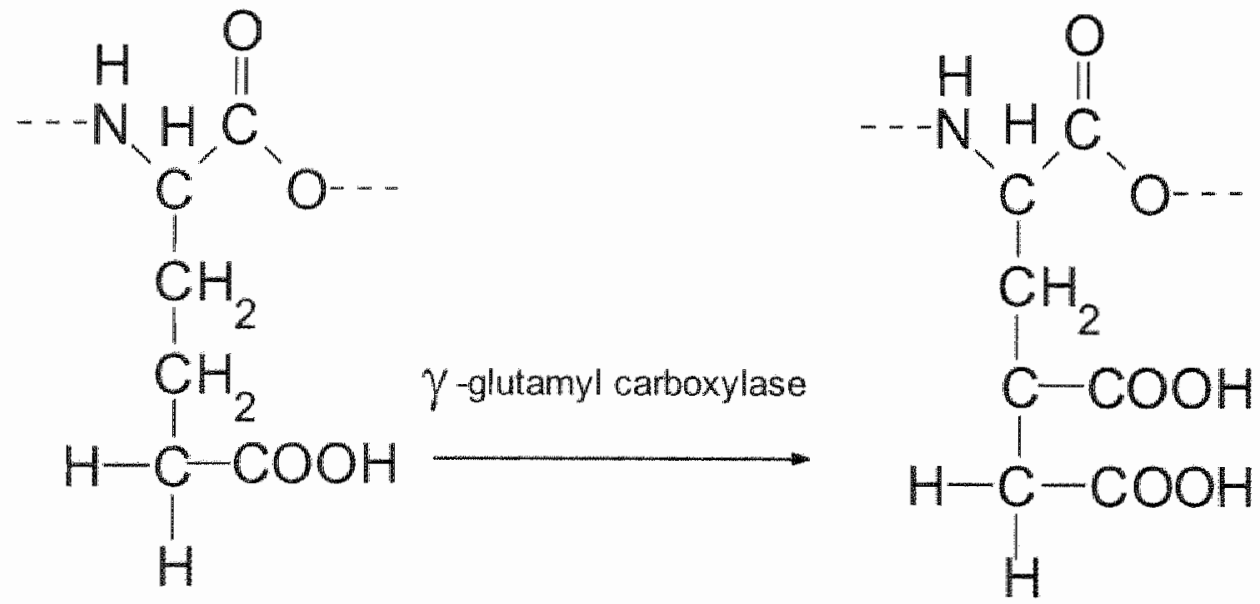

\section{G/u}

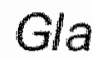

Figure 3: $\quad$ Structures of glutamic acid (Glu) and y-carboxy glutamic acid (Gla) 
Subsequent investigations showed that the Gla-residues bind $\mathrm{Ca}^{2+}$, which is necessary for the biological activity of various coagulation factors, and that vitamin $K$ promotes the formation of specific glutamic acid residues (Glu) into Gla during the postrranslational modification stage of protein biosynthesis (figure 3 ) $^{24,25}$.

For a long time it has been thought that prothrombin and the factors VII, IX, and $X$ were the only proteins that required vitamin $K$ for their synthesis. However, during the last 25 years various vitamin $\mathrm{K}$-dependent proteins have been discovered both in mammalian cells and in invertebrate cells ${ }^{27,28}$. These Gla-proteins require $\mathrm{Ca}^{2+}$ either for their binding to phospholipid surfaces, the regulation of tissue mineralization, or for the regulation of cell growth. In all cases in which their function is known, the binding of $\mathrm{Ca}^{2+}$ to Gla-residues is essential for the activity of the various Gla-proteins (figure 4). Since also Gla-proteins of (a yet) unknown function have been discovered (e.g. the proline-rich Gla-proteins, PRGP's ${ }^{29}$ ) another $\mathrm{Ca}^{2+}$-independent role for Gla-residues cannot be excluded.

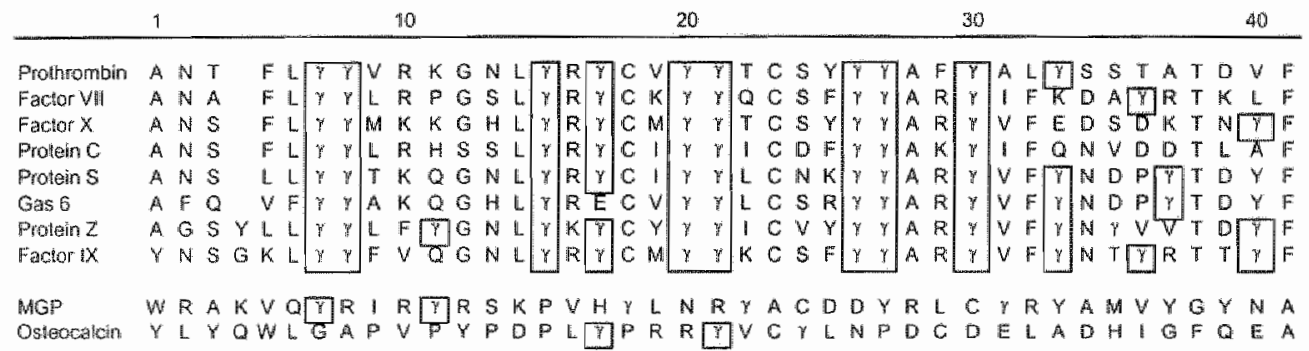

Figure 4: The Gla-domains of all the known human vitamin K-dependent proteins. The sequence is in the one letter code; y stands for Gla, highly homologous Gla residues are boxed, MGP stands for matrix Gla protein

No homology between MGP andlor Osteocalcin and the other vitamin K-dependent proteins can be detected

However, since Gla has been discovered in both vertebrates and invertebrates, this amino acid obviously plays an important role in protein function. 


\section{The vitamin $\mathrm{K}$-dependent carboxylation reaction}

The vitamin $\mathrm{K}$ mediated conversion of Glu to Gla is one of the alleged post-translational conversions such as glycosilation, hydroxylation, phosphorylation, and disulfide bond formation, which take place during protein synthesis. These processes occur at the luminal side of the rough endoplasmic reticulum (RER), after which the processed proteins are transported through the luminal area of the RER via the Golgi apparatus to the extracellular environment. These type of proteins are generally referred to as secretory proteins. All known Gla-proteins are secretory proteins with the possible exception of carboxylase itself ${ }^{30}$, or the putative Proline Rich Gla Proteins 1 and 2 (PRGP1 and PRGP2) ${ }^{29}$. The PRGP CDNA's predict amino acid sequences that contain a potential transmembrane region and a proline rich cytoplasmic domain. Until now only<smiles>Cc1c(O)c(OCCSC[C@@H]2CCC2C)c2ccccc2c1O</smiles>

Vitamin $\mathrm{KH}_{2}$

$$
\text { WEAK BASF }
$$

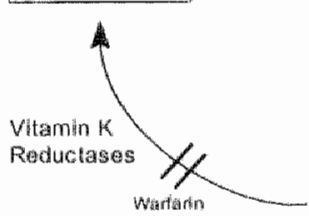

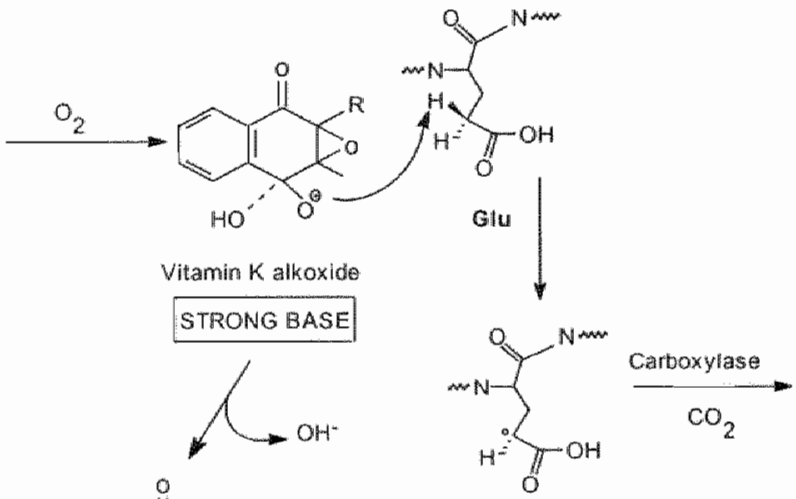

Glu<smiles>CNC(=O)C(CC(C(=O)O)C(=O)O)NC</smiles>

Gla<smiles>[R]C12OC1(C)C(=O)c1ccccc1C2=O</smiles><smiles>C[Hg]</smiles>

Vitamin Kepoxide

Figure 5: Biasynthetic pathway for vitamin K-dependent production of Gla. It has been hypothesized that a free cysteine residue present in the carboxylase converts $\mathrm{KH}_{2}$ into a strong base, able to abstract a hydrogen from the $y$-carbon of Glu ${ }^{32}$. In a next reaction step $\mathrm{CO}_{2}$ is added to the $y$-carbon of Glu to form Gla. The activated vitamin $\mathrm{K}$ alkoxide collapses into vitamin $\mathrm{K}$ epoxide and is converted back to $\mathrm{KH}_{2}$ by the action of two vitamin $K$ reductases which are sensitive to warfarin. 
the mRNA's of these proteins have been demonstrated, but no functional protein has been detected or isolated yet. Moreover the $\gamma$-glutamyl carboxylase itself has been shown to be a transmembrane Gla-protein ${ }^{30}$. Although vitamin $K$ in the human food is mainly present in the quinone $(K)$ form, the active cofactor for carboxylase is reduced vitamin $\mathrm{K}$, vitamin $\mathrm{K}$ hydroquinone $\left(\mathrm{KH}_{2}\right)$. During the carboxylation reaction $\mathrm{KH}_{2}$ is converted into vitamin $K$-epoxide (KO) in the same reaction in which $G$ lu is converted: to Gla in a 1: stoichiometry, and in the presence of both $\mathrm{CO}_{2}$ and $\mathrm{O}_{2}$ Carboxylation of Glu residues within the Gla-domain of vitamin K-dependent proteins is a processive mechanism ${ }^{31}$, which implies multiple carboxylations to occur within one molecule during a single association with the enzyme. A recently proposed mechanism for the carboxylation reaction is that of basicity enhancement by which oxygenation of vitamin $\mathrm{KH}_{2}$ results in the generation of a strong active oxygenated base which then removes a proton from the $\gamma$-carbon of glutamic acid ${ }^{32}$. The active vitamin K intermediate, which is potentially toxic, collapses subsequently to vilamin $\mathrm{KO}$ and the glutamate carbanion undergoes carboxylation to yield $y$-carboxyglutamic acid (figure 5) ${ }^{33}$.

Because of its toxicity, it is undesirable to generate the vitamin $K$ intermediate intracellularly. Therefore it is not present in the absence of substrate glutamate residues 34. In two following steps vitamin $\mathrm{KO}$ is reduced to vitamin $\mathrm{K}$ and vitamin $\mathrm{KH}_{2}$ by the action of one or more dithiol dependent reductases (figure 6). This "recycling" mechanism explains why the daily requirement for vitamin $K$ is low and thus why vitamin $K$ deficiency is rarely seen in healthy subjects ${ }^{35,36}$.

More recently, two components of multiprotein enzyme complex vitamin $K$ epoxide reductase have been identified: microsomal epoxide hydrolase and a glutathione S-transferase super gene family member ${ }^{37}{ }^{3}$. The dithiol-dependent reduction of $K O$ and $K$ is not the only mechanism $\mathrm{known}$ to generate $\mathrm{KH}_{2}$. Vitamin $\mathrm{K}$ quinone (and not KO) may be reduced by DT-diapharase, an NAD(P)H dehydrogenase, but since this pathway does not allow recycling of vitamin $K$, a blockade of the dithioldependent pathway leads to an at least 1000 -fold increased vitamin $K$ requirement ${ }^{39}$. Therefore the $\mathrm{NAD}(\mathrm{P}) \mathrm{H}$-dependent reductase does not play an important role in case of physiological concentrations of witamin $K$ in wivo ${ }^{39}$. The dithiol-dependent pathway 


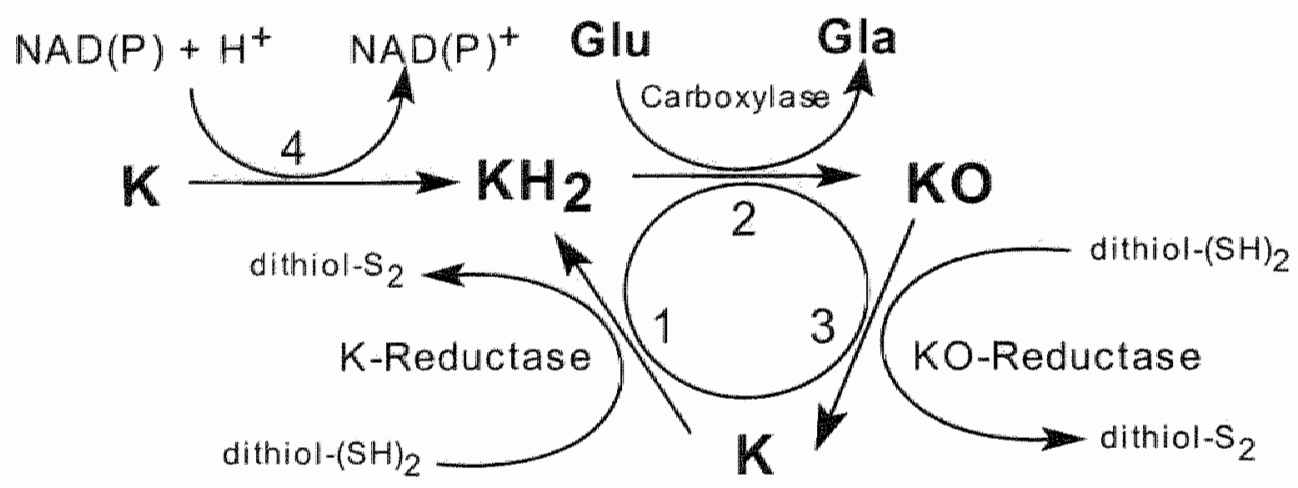

Figure 6: Schematic representation of the vitamin $K$ cycle. Vitamin $K$ is reduced to $\mathrm{KH}_{2}$ via the dithiol dependent step 1 . Step 2 is the subsequent carboxylase / epoxidase reaction in which Glu is converted to Gla. Step 3 is the reduction of vitamin $\mathrm{K}$ epoxide to $\mathrm{KH}_{2}$. Step 4 is required in case of anticoagulation (phenprocoumon) therapy or rodenticide poisoning, since steps 1 and 3 are blocked in this situation.

of vitamin $\mathrm{K}$ recycling is sensitive to coumarin anticoagulants such as acenocoumarol, warfarin and phenprocoumon ${ }^{40}$. Treatment of patients suffering from thromboembolic disease with coumarin-type anticoagulants is based on the prevention of reduction of vitamin $\mathrm{K}$ and $\mathrm{KO}$ by blocking the dithiol-dependent reductases. In this way the vitamin $K$-dependent coagulation factors are synthesized in an inactive form and cannot contribute to blood coagulation ${ }^{41}$. Intoxication with coumarins as a result of ingestion of rat poison must be treated with high daily doses of vitamin $K$, and is invariably associated with the appearance of vitamin $\mathrm{KO}$ in plasma after the administration of vitamin $K$. In this case the $\mathrm{NAD}(\mathrm{P}) \mathrm{H}$-dependent reductase is the sole enzyme generating vitamin $\mathrm{KH}_{2}$ in vivo to overcome the intoxication.

\section{Vitamin K-dependent proteins}

During recent years a large variety of vitamin $K$ dependent Gla proteins have been 
discovered that are involved in a) haemostasis $6.8,24,42-44$, b) mineralization processes ${ }^{45.46}$, c) regulation of cellular proliferation ${ }^{11.4 \%, 45}$ and d) other processes. Below the proteins in these three categories will be discussed briefly.

\section{A. Haemostasis}

Haemostasis is a complex process which is triggered by the release of tissue factor (TF) after injury of a blood vessel and which results in the formation of a fibrin clot via a cascade of zymogen activations. In this cascade about 15 different proteins are involved, 7 of which are Gla-proteins. $\mathrm{Ca}^{2 *}$ mediated binding to negatively charged phospholipid surfaces is essential for either the activation or the function of these proteins, or both.

Prothrombin (FII) was the first protein discovered to contain

Gla-residues ${ }^{24,25,49}$, soon followed by factors $V / \|, I X$ and $X{ }^{42,43}$. These proteins are all involved in the formation of thrombin and thus in the pro-coagulant properties of blood. Proteins $\mathrm{C}$ and $\mathrm{S}$ are also Gla-proteins but regulate blood coagulation by inhibiting it. Protein $C$ is activated by thrombin to activated protein $C$ (APC). APC on its turn inactivates both activated and non-activated factors $V$ and VIII by proteolytic cleavage.

Protein S serves as a cofactor for the inactivation of factors Va and VIlla by APC. The cofactor activity of protein $S$ is regulated by $C_{4}$-binding protein (C4BP) ${ }^{50}$, a member of the classical complement pathway. Approximately $40 \%$ of the protein $S$ is available for this cofactor function. whereas $60 \%$ of the protein is bound to C4BP and thus lacks cofactor activity ${ }^{50}$. Moreover, it is demonstrated that protein $S$ is synthesized by osteoblasts in bone ${ }^{51}$, and that protein $S$ deficiency in children results in reduced bone mineral density and increased fracture risk of the vertebra " Nakamura et al. ${ }^{53}$ demonstrated that protein S enhances the bone resorbing activity of mature osteoclasts suggesting that protein $S$ is a direct regulator of osteoclastic function.

Protein $Z$, the physiological role of which remained unknown until 1991, is involved in thrombin fixation. This was demonstrated by Hogg and Stenflo 54 who reported that protein $Z$ binds to thrombin in a $\mathrm{Ca}^{2+}$-independent way. Furthermore these authors showed that protein $Z$, when bound to phospholipid vesicles, bound to thrombin 
and therefore could function as an intermediate to retain thrombin to the site of a vascular injury.

\section{B. Mineralization processes}

The discovery of Gla also led to the identification of vitamin K-dependent proteins not related to blood coagulation. These proteins were isolated from bone ${ }^{7}$, atherosclerotic plaque ${ }^{55,56}$, renal calculi ${ }^{57}$ and kidney ${ }^{58,59}$, but were not sufficiently characterized in all cases. It is possible that most of these reports were refering to the same protein, later identified as matrix Gla-protein (MGP).

The first Glamprotein to be discovered in bone was osteocalcin or bone Glaprotein (BGP) ${ }^{7,60}$, the most abundant non-collagenous protein found in bone. Osteocalcin synthesis is induced in osteoblasts by the vitamin $\mathrm{D}$ metabolite 1,25 dihydroxy- $\mathrm{D}_{3}\left(1,25(\mathrm{OH})_{2} \mathrm{D}_{3}\right)^{61,62}$. Its function was demonstrated by Ducy et al ${ }^{63}$, who showed that osteocalcin deficient mice displayed an increased bone formation, and therefore the authors concluded that osteocalcin limits bone matrix formation without affecting resorption or mineralization. Thus, osteocalcin was identified as a negative regulator of bone formation.

The second Gla-protein isolated from bone was matrix Gla protein (MGP) ${ }^{\text {io }}$. It did not take long before it was demonstrated that MGP was predominantly found in cartilage and in various soft tissues ${ }^{64}$. In developing bone it is associated mainly with the nonmineralized matrix, and therefore it appears earlier than osteocalcin ${ }^{65}$. Its function in mineralization processes was clearly demonstrated by Luo et al "who reported that MGP deficient mice underwent spontaneous calcification of the arteries and cartilage. Absence of MGP also resulted in inappropriate calcification of the growth plate cartilage and caused short stature, osteopenia and fracture. Therefore the authors concluded that MGP is an inhibitor of soft tissue calcification. Price et al. recently demonstrated that the vitamin $K$ antagonist warfarin was capable of inducing similar results as observed in the MGP deficient mice ${ }^{66}$. Since vitamin K cannot counteract the effect of warfarin in extrahepatic tissues, the synthesis of Gla-proteins can be blocked in these tissues by a combination of warfarin and vitamin $K$, without the risk of 
bleeding ${ }^{57}$. Using this regiment it could be shown that rats developed calcifications of the elastic lamellae in arteries and heart valves within 3-5 weeks.

\section{Regulation of cell growth}

Growth arrest specific gene 6 product (Gas6) is one of the more recently discovered vitamin K-dependent proteins but has only been investigated in cell culture systems thus far. Manfioletti et al. reported that it is expressed in many human and murine tissues and may be involved in the regulation of a protease cascade relevant in growth regulation ". Gas 6 has been demonstrated to be a ligand for several receptor tyrosine kinases ${ }^{68,69}$ a function for which Gla residues are essential ${ }^{70}$. Furthermore, Nakano et al ${ }^{47}$ showed that Gas6 specifically potentiates vascular smooth muscle cell (VSMC) proliferation mediated by $\mathrm{Ca}^{2+}$-mobilizing receptors and prevents cell death if VSMC are starved. Since Gas6 is involved in the in vitro maintenance of growth arrested VSMC's and the proliferation of growing VSMC's this suggests that Gas 6 may be essential for the development and maintenance of the arterial vessel wall and the process of atherosclerosis ${ }^{70}$. Other authors reported Gas 6 to be capable of inducing the re-entry of starved NIH3T3 cells into the cell cycle and thus preventing cell death by apoptosis 71. Nakamura et al. more recently demonstrated that Gas6 enhanced bone resorbing activity of mature osteoclasts, and that this function could be inhibited by a tyrosine kinase inhibitor ${ }^{53}$. These results indicate that Gas6 is also involved in bone resorption in vivo.

\section{Other}

The enzyme $\gamma$-glutamyl carboxylase itself was recently reported to a Gla-protein ${ }^{30}$, containing $3 \mathrm{Gla}$ residues per molecule carboxylase. The physiological importance of this remarkable observation is unclear as yet.

The cDNA's of the proline rich Gla proteins 1 and 2 (PRGP1 and PRGP2) were reported recently by Kulman et al ${ }^{29}$. These proteins are putative since the corresponding proteins have not yet been found. CDNA's were synthesized from mRNA's using primers based on a DNA sequence from an expressed sequence 
database that was discovered using the query sequence LEEXXXXXLERECXEEXCXXEEARE. This sequence was derived via alignment of all known human Gla domain sequences. Both PRGP's contain potential transmembrane domains, which makes thern distinct from the other Gla-proteins. Possibly both PRGP's are members of a yet undiscovered family of transmembrane Gla-proteins.

\section{The y-glutamyl carboxylase}

The enzyme $\gamma$-glutamyl carboxylase is an integral transmembrane protein of the RER and consists of 758 amino acids with a molecular weight of $94 \mathrm{kDa}$. The cDNA sequences for both human ${ }^{72}$ and bovine ${ }^{73}$ carboxylase have been reported. Their sequences predict a hydrophobic region including a minimum of 5 and a maximum of 7 transmembrane domains surrounded by a hydrophilic stretch both at the $\mathrm{N}$-terminal and the C-terminal region. The C-terminal hydrophilic region contains eight of the nine potential glycosylation sides ${ }^{72}$.

Y-Glutamyl carboxylase occurs in liver ${ }^{74}$ as well as in a large variety of other tissues such as lung, kidney, testis ${ }^{74}$, spleen, pancreas, thyroid, vessell wall, bone (osteoblasts) $^{75,76}$, tumor cells and skin ${ }^{77,78}$. Although not yet proven, it is generally accepted that the carboxylases from the various lissues are the product of the same gene, located on chromosome 2 at position $p 12^{79}$. After its chromosomal location had been discovered, the complete genomic sequence including the transcription start site of the enzyme was reported ${ }^{10}$. Furthermore, a recent study showed that the $y$-glutamyl carboxylase could carboxylate itself, both in vitro and in vivo in a reaction dependent on witamin $K^{30}$. Berkner demonstrated that carboxylase contains 3 moles of Gla per mole of carboxylase and suggested that carboxylase in vitro is involved in substrate turnover whereas in vivo these results suggested a potential role of Gla in carboxylase stability. Whether carboxylase is capable of autocarboxylation vila an intramolecular process or is carboxylated by a different carboxylase molecule via an intermolecular reaction remains unclear, although the intramolecular mechanism is the most likely one. Price and Williamson observed a sequence within carboxylase sharing homology over 
24 residues $(495-518)$ with the MGP region $14-37$ which covers the internal recognition site for carboxylase ${ }^{34}$. These authors suggested that this sequence might block the active site of the enzyme and thereby play a regulatory role in preventing nonspecific protein carboxylation. However, it was shown by Berkner and Pudota that carboxylase is capable of carboxylating itself without the requirement of an exogenous propeptide containing substrate ${ }^{30}$. This suggests strongly that the regulatory theory of Price and Williamson does not apply to the carboxylation of carboxylase itself.

The propeptide binding site present on carboxylase has been demonstrated by several authors using substrate- and propeptide-based affinity labeling reagents ${ }^{\text {s2-s6 }}$ " However, these authors report different locations of the propeptide binding site on the enzyme between residues 1 and $225^{82-85}$, between residues 438 and $758^{86}$. Another group reports the position of the active site on carboxylase to be located between residues 350 and $508^{87}$. The reason for these differences may be due to variations in affinity labelling experiments giving different results. Although it is not clear yet the propeptide binding site and possibly the Glu binding site of carboxylase is located in the $\mathrm{N}$-terminal third and central third of the enzyme ${ }^{34}$.

\section{Purification of $y$-glutamyl carboxylase}

Several attempts to purify the vitamin K-dependent carboxylase from bovine liver have been made. The first author describing a 400 fold purification of the carboxylase was Girardot ${ }^{38}$. De Metz et al. used an immobilized factor $X$ antibody, capable of binding carboxylase from coumarin treated animal liver via the complexed factor $X$ precursor ${ }^{89}$. This "solid phase carboxylase" retained its activity for FLEEL. Hubbard et al. ${ }^{90}$ and Harbeck et al. ${ }^{91}$ reported similar results but unfortunately the specific activity of the solid phase carboxylase differed not substantially from the preparations by Girardot ${ }^{\text {Bg }}$. Wu et al. were the first to report the purification of bovine carboxylase to near homogeneity ${ }^{92}$. These authors used a recombinant protein, produced in Escherichia coli, which consisted of the propeptide attached to the Gla-domain of the human factor IX precursor molecule (ProlX-59 Q/S) ${ }^{93}$. This 59 amino acid long substrate displayed 


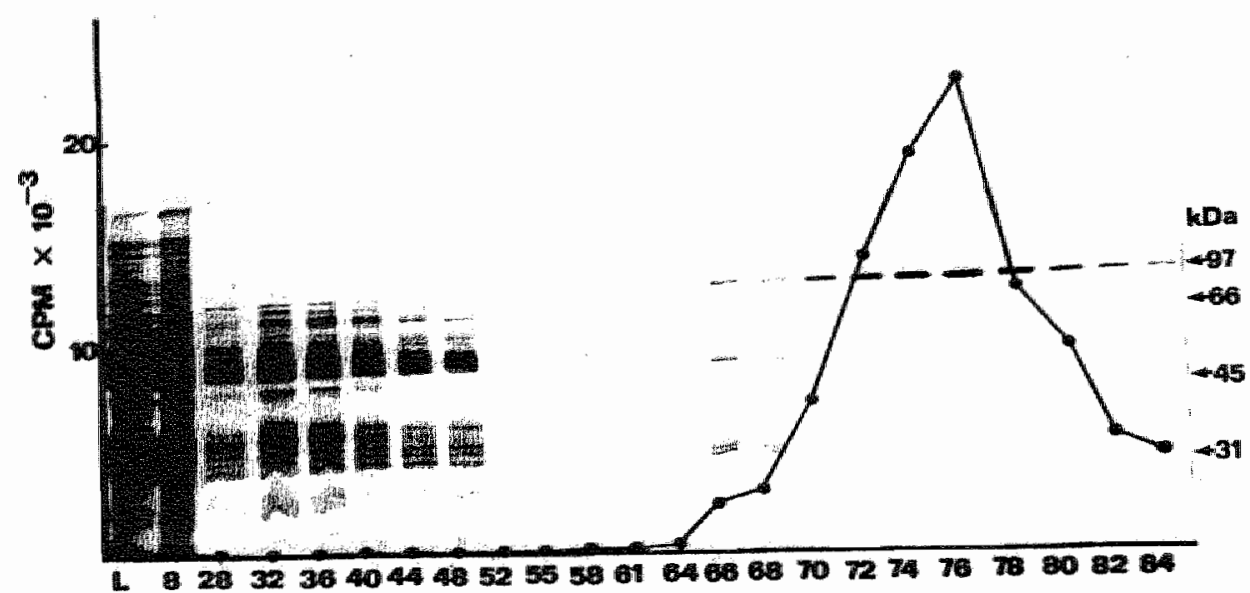

Figure 7: Activity profile and reducing SDS-PAGE analysis (10\% silver-stained gel) of fractions from Affi-FIXO/S chromatography eiution. The farction number is shown on the $x$ axis. whereas the $y$ axis represients the carboxylase activity in each lane. Carboxylase activity was determined by the ${ }^{84} \mathrm{CO}_{2}$ incorporation into FLEEL. Lane $\mathrm{L}$ is microsomal loading material; fractions $1-20$ are flow-through (only one is shown); fractions 21-30 are wash; fractions $31-49$ are Triton $X-100$ gradient; fractions 56-63 are CHAPS gradient; fractions 64-75 are CHAPS / proFIX19 double gradient; fractions 76-90 are 1 $\%$ CHAPS / $2 \mu \mathrm{M}$ proFIX19 elution. Molecular mass are shown on the right. Figure from Wu et al, $1997^{94}$.

a $K_{m}$ for carboxylase in the submicromolar range. Affinity chromatography of ProlX-59 Q/S as a solid phase ligand resulted in the specific extraction of carboxylase from solubilized bovine liver microsomes. Next, the enzyme was eluted with propeptide of factor IX (proFIX19) resulting in a carboxylase preparation which had a 185 -fold higher specific activity than that obtained with the best method previously described ${ }^{90}$. The molecular weight of the purified carboxylase was $94 \mathrm{kDa}$ (figure 7). Previous attempts to purify carboxylase using only the propeptide coupled to a solid phase had resulted in the purification of a protein with a molecular weight of $77 \mathrm{kDa}{ }^{90}$. Subsequent experiments showed that the protein in case was not carboxylase, but BiP, one of the most abundant proteins present in the endoplasmic reticulum ${ }^{92}$. It was suggested by Wu et al. that BiP preferentially binds small peptides (e.g. propeptide), since it was not present in the preparation by Wu et al. ${ }^{92}$. Also no carboxylase activity for BiP was found.

The fact that the carboxylase purified by Wu et al. ${ }^{92,94}$ was of bovine- in stead 
of human origin was one of the disadvantages of this purification. Since research was mainly focussed on human carboxylase, a method to obtain sufficient carboxylase of human origin was desired. Another disadvantage was the presence of $2 \mu \mathrm{M}$ propeptide in the preparation after the elution of carboxylase from the solid phase. Interactions between pro-containing substrates and the purified carboxylase in vitro are expected to be interfered by the propeptide present. As a consequence a propeptide-free purification protocol for human carboxylase was necessary. Several authors described the construction and in vitro expression of recombinant (human) carboxylase in various cultured cells ${ }^{95,96}$. However, these protocols use free propeptide in the final elution step of the carboxylase, apparently to stabilize the carboxylase. Using a Trichoplusia ni High Five insect cell line, which overexpresses transiently infected human y-glutamyl carboxylase cDNA, it was demonstrated by Stafford et al. that carboxylase can be purified without the need of a free propeptide. Transcription and subsequent translation of the cDNA resulted in a carboxylase with a covalently attached affinity tag at the Cterminus of the molecule. Impure carboxylase from solubilized insect cell microsomes is bound to an affinity resin in the presence of $\mathrm{Ca}^{2+}$. Subsequently the resin is washed and the carboxylase is eluted from the resin using an ethylenedinitrilo tetraacetic acid (EDTA) concentration gradient. This purified carboxylase was fully active without the need of stabilizing propeptide present. The purification of human $\mathrm{y}$-glutamyl carboxylase from insect cells is described in more detail in chapter 4 of this thesis.

\section{The vitamin K-dependent carboxylation reaction in vitro}

Shah and Suttie $^{97}$ were the first authors to report a reaction in which postmitochondrial supernates from vitamin $\mathrm{K}$ deficient rats responded to the in vitro addition of vitamin $\mathrm{K}$ by producing prothrombin. They reported that this system was energy dependent, and that is was inhibited by antagonists of vitamin $\mathrm{K}$ but not by cycloheximide, a cytostatic, added to inhibit de novo synthesis of prothrombin. The authors concluded that the system represented a conversion of endogenous rat liver prothrombin precursor to prothrombin by modification of the precursor molecule through attachment of a calcium 
binding group. The authors also claimed that this conversion invalved carboxylation of glutamyl residues, rather than the synthesis of new prothrombin polypeptide. Subsequently, other investigators applied a similar system using mirosomal preparations from both warfarin treated and normal rats and cows ${ }^{98-104}$, in which $\mathrm{NaH}^{14} \mathrm{CO}_{3}$ was used to measure ${ }^{14} \mathrm{CO}_{2}$ incorporation into the endogenous precursor proteins present in the microsomal preparations. This reaction turned out to be dependent on $\mathrm{O}_{2}, \mathrm{CO}_{2}$, vitamin $\mathrm{K}, \mathrm{NAD}(\mathrm{P}) \mathrm{H}$ and/or a reduced nucleotide-generating system. In the early experiments vitamin K-quinone was used as a cofactor for carboxylase. Under these conditions relatively low ${ }^{14} \mathrm{CO}_{2}$ incorporation rates were found. After adding $\mathrm{NAD}(\mathrm{P}) \mathrm{H}$ to the microsomes the incorporation rates doubled, suggesting that vitamin $\mathrm{K}$ had to be reduced before it could function as cofactor for carboxylase. Later it was demonstrated that $N A D(P) H$ could be omitted by using the reducing agent dithiol threithol (DTT), which inreased ${ }^{14} \mathrm{CO}_{2}$ incorporation fivefold, thus providing further evidence for the necessity of $\mathrm{KH}_{2}$ in the carboxylation reaction ${ }^{100,10 \%}$. Finally, the in vitro carboxylation reaction was shown to be maximally stimulated by $\mathrm{KH}_{2}$ even in the absence of reducing agents like DTT.

Triton $X-100$ was frequently used to solubilize the microsomal fraction but was later replaced by 3-[(3-cholamidopropyl)dimethylammonio]-1-propanesulfonate (CHAPS). This solubilized washed microsomal system contained all activities necessary for carboxylation in vitro.

\section{Substrate specificity of $\gamma$-glutamyl carboxylase, function of the propeptide}

The first in vitro substrates for $\gamma$-glutamyl carboxylase were based on homologous amino acid sequences of the Gla domains of mature vitamin K-dependent proteins. The peptides synthesized were Phe-Leu-Glu-Glu-Leu (FLEEL) and Phe-Leu-Glu-Glu-Val (FLEEV), similar to residues 5 to 9 of various descarboxy blood coagulation factors ${ }^{102}$, Suttie and Hageman used this sequence in particular although the Gla domain of bovine descarboxy-prothrombin consists of 10 Glu residues at positions $7,8,15,17$, $20,21,26,27,30$ and $33^{49}$. The reason to choose a short peptide was that the 
published prothrombin sequence did not reveil a unique sequence which might act as a recognition signal for carboxylase, and the choice for FLEEL was mere coincidence 102. FLEEL was carboxylated in vitro but displayed a low affinity for carboxylase, resulting in $\mathrm{K}_{\mathrm{m}}$ values in the millimolar range. These results suggested that in vivo substrates for carboxylase must contain a high affinity recognition sequence outside the Gla-domain. Therefore, intact heat-decarboxylated coagulation factors such as prothrombin were used as a substrate, but again very high $K_{m}$ values for carboxylase were found ${ }^{103}$. Since the plasma concentrations of prothrombin in vivo are so low (in the micro to nano molar range), the $\mathrm{K}_{\mathrm{m}}$ value of thermally decarboxylated prothrombin was expected to be in that range also. An exception was heat-decarboxylated bovine osteocalcin, which had low $K_{m}$ values for carboxylase ${ }^{104}$. Whether this high affinity was due to protein damage as a result of the thermal decarboxylation remained unclear. Later it was shown by Engelke et al ${ }^{105}$ that heat decarboxylated MGP displayed similar substrate properties as heat-decarboxylated osteocalcin.

In 1987 several authors reported independently that a "propeptide" could be responsible for the high affinity of Gla-protein precursors for carboxylase ${ }^{106-100}$. In vivo the 18 amino acid residues of the propeptide are removed prior to secretion by a peptidase-cleavage between arginine -1 and tyrosine 1 , to yield the mature protein sequence. A significant contribution to our insight in the posttranslational processing of Gla-proteins was made by analysis of three naturally occurring factor IX mutants; factor IX Cambridge ${ }^{110}$, factor $\mid \times$ Oxford-3 ${ }^{111}$, and factor $1 \times$ San Dimas ${ }^{112}$. The resulting defects are caused by point mutations in the gene which resulted in a serine to arginine substitution at position -1 in factor IX Cambridge and a glutamine to arginine substitution at position -4 in both factors IX Oxford-3 and IX San Dimas. As a consequence, the propeptide is not removed by protease cleavage and therefore the mutant proteins circulate in plasma with the propeptide still attached ${ }^{106}$. N-terminal protein sequence analysis revealed the presence of residues -18 to -1 in the mutated molecules and thereby the length of the factor $1 X$ propeptide could be defined ${ }^{100}$. Subsequent cDNA analysis of prothrombin ${ }^{13_{3}}{ }^{14}$, factor $\chi^{115,116}$, factor $\mathrm{V} /{ }^{117}$, protein $\mathrm{C}$ ${ }_{118-120}$, protein $S^{124,122}$, and osteocalcin ${ }^{\$ 23.124}$ rewealed that the latter proteins, like factor 


\begin{tabular}{lllll}
-18 & -16 & -10 & -6 & -1 \\
\hline
\end{tabular}

\begin{tabular}{|c|c|c|c|c|c|c|c|c|c|c|c|c|c|c|c|}
\hline Prothrombin & $H$ & & & & & 0 & & L & 1 & $Q$ & 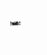 & - & - & 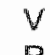 & \\
\hline Factor VII & $R$ & v & $V T$ & $Q$ & $E$ & $E$ & $H C$ & $\mathrm{~V}$ & 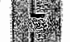 & $\mathrm{H}$ & - & - & 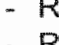 & $k$ & \\
\hline Factor IX & T & & $L D$ & $H$ & $E$ & $N$ & $\mathrm{NK}$ & $<1$ & 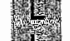 & $\mathbb{N}$ & - & - & - & 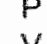 & $K$ \\
\hline Factor $X$ & $\mathrm{~s}$ & $\mathrm{~L}$ & I R & $R$ & $E$ & $Q$ & $N N$ & 41 & the & A & - & - & - & $\mathrm{V}$ & \\
\hline Prote & $s$ & 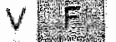 & S $S$ & $s$ & $E$ & $R$ & $\mathrm{HCO}$ & $2 \mathrm{~V}$ & & $R$ & - & - & - & $\mathrm{R}$ & \\
\hline rote & A & $\mathrm{N}$ WE & L $S$ & K & $Q$ & $Q$ & $s c$ & $2 \mathrm{~V}$ & & $\mathrm{~V}$ & - & - & $=$ & K & \\
\hline Protein $Z$ & $s$ & & L. P & $A$ & $S$ & $K$ & $\mathrm{ND}$ & $\mathrm{V}$ & & $\mathrm{V}$ & - & - & - & N & \\
\hline PRGP1" & $\mathrm{R}$ & & $L T$ & $\mathrm{G}$ & $E$ & $K$ & $N S$ & 81 & & $K$ & - & - & - & 6 & \\
\hline PRGP2 & $E$ & $\mathrm{~V}$ & $L G$ & $\mathrm{P}$ & $P$ & $E$ & $Q S$ & $S F$ & & $\mathrm{~s}$ & $S$ & $H$ & $T R$ & 1 & \\
\hline Matrix Gla Protein & $N$ & $P$ & $1 \mathrm{~N}$ & $R$ & $\mathrm{R}$ & N & $N T$ & $F$ & 1 & S & - & - & & & \\
\hline Osteocalcin & A & A & $V s$ & $K$ & $\mathrm{a}$ & $E$ & $S B$ & $E V$ & & $k$ & - & - & & & \\
\hline
\end{tabular}

Figure 8:

The propeptide sequences of all the known vitamin K-dependent proteins (with the exception of Gas-6) in the one-letter code. The highly conserved amino acid residues are boxed in grey.

"Aligned in such a way to create maximal homology

$\mathrm{X}$, are synthesized in the form of precursor molecules. The precursor molecules contain a hydrophobic signal peptide and a propeptide (figure 8 ) ".106. Considerable sequence homology between the various vitamin $K$-dependent proteins was found in the amino terminal Gla domain, two epidermal growth factor (EGF) domains (protein C, factors $V I I, I X$ and $X)^{125}$, a connecting region, containing an activation peptide, and a trypsin-like serine protease domain (except protein $S$ ) ${ }^{107}$. However, the mature form of osteocalcin has no homology with Gla-proteins involved in blood coagulation. The protein sequence of mature MGP revealed that it contains an internal peptide sequence sharing homology with the propeptide sequence found in the Gla-proteins ${ }^{126}$. Based on the results of the cDNA analysis of the Gla-proteins it was proposed that the propeptide designates specific precursor proteins for $\gamma$-carboxylation 110,111,120,121,124,127. Moreover it was demonstrated by Price et al. that all Gla-proteins contain a highly conserved GluXaa-Xaa-Xaa-Glu-Xaa-Cys (EXXXEXC) sequence structure "These authors suggested that this sequence could function as an indicator for carboxylase to distinguish between the substrate and the carboxylated product ${ }^{109}$.

Increasing knowledge about structural requirements for carboxylatable substrates initiated the development of high affinity substrates for in vitro carboxylation. Cheung et al. were the first to synthesize the propeptide of human factor $X$ and 
determine its characteristics in combination with several short Glu-containing peptides (bEELOMe, FLEEL, bLEEL, ALEEPA) to carboxylase ${ }^{128}$. Addition of $10 \mu$ M free factor $X$ propeptide to rat liver carboxylating reaction mixture increased ${ }^{14} \mathrm{CO}_{2}$ incorporation in these peptides 12 -fold and lowered the apparent $K_{\mathrm{m}} 8$-fold. Free propeptide did not affect the $\mathrm{K}_{\mathrm{m}}$ for vitamin $\mathrm{KH}_{2}, \mathrm{O}_{2}$ or $\mathrm{CO}_{2}{ }^{128}$. These results confirmed the hypothesis that the propeptide is required for high affinity binding to carboxylase. Uirich et al. were the first to report the synthesis and subsequent carboxylation of a high affinity in vitro substrate ${ }^{129}$. They reported the synthesis of a peptide consisting of residues -18 to +10 of pro-prothrombin (ProPT-28). The $K_{m}$ of this peptide was $4 \mu M$. Subsequently, other groups reparted the synthesis of recombinant propeptide containing substrates ${ }^{93,130-132}$. These substrates also had high affinity for carboxylase with $K_{m}$ values in the micromolar range. Mutations induced at various sites in the propeptide resulted in a decreased affinity of the propeptide for carboxylase ${ }^{93,132,133}$. Recent results have shown that a covalently attached propeptide directs carboxylation of adjacent Glu-rich regions, even if these sequences are not structurally related to any Gla-domain ${ }^{74,130,134}$. Since oxidation of $\mathrm{KH}_{2}$ preceeds the conversion of Glu to Gla on the substrate and this can not occur without the formation of $\mathrm{KO}$, this suggests that epoxidation of vitamin $K$ by carboxylase is stimulated by the propeptide ${ }^{34}$. The propeptide can be defined by $a Z$ Z-F. $Z-X-X-X-X-X-A-X-X-Z-Z$ motif from residues -17 to -6 , in which $Z$ is an aliphatic hydrophobic residue (lle, Val, Leu), $F$ stands for phenylalanine, $A$ is alanine and $X$ represents any amino acid. Although phenylalanine is preferred at position

-16 of carboxylase substrates, other residues such as alanine, lycine, leucine and valine are also well carboxylated (e.g. Gas6 or ProPT-28 F/A). The propeptide region of the precursor proteins presumably dock with carboxylase, resulting in a conformational change of the enzyme and thus bringing the active site in close proximity to the Glu residues of the precursor proteins. The enzyme responsible for the removal of the propeptide from the Gla proteins is not known "although a role for Furin in this process has been suggested ${ }^{135}$. There is, however, a large family of related enzymes, called proconvertases, involved in the cleavage of propeptides containing arginine or lysine residues at position -2 and arginine residues at position $-1^{136}$. Furie et al. hypothesized 
very recently that any protein will undergo $y$-carboxylation if : (1) the protein includes a propeptide which interacts with carboxylase; (II) the protein is transported through the RER during protein biosynthesis; (111) the cell has the carboxylase enzyme associated with the RER; (IV) there are Glu residues present within 40 residues of the propeptide; and $(V)$ intracellular vitamin $K$ is present ${ }^{34}$.

Fully carboxylated Gla proteins bind phopholipid membranes in the presence of $\mathrm{Ca}^{2+}$. After the binding and subsequent carboxylation of the precursor Gla-proteins like proprothrombin the propeptide is still attached and the precursor protein is transported to the trans Golgi network. During this transport the proprothrombin does not bind to the endoplasmic reticular membranes although the $\mathrm{Ca}^{2 *}$ concentration in the endoplasmic reticulum is much higher than in the cytoplasm. Presumably this is caused by the propeptide which is, in this phase of the processing, still attached and thus prevents proper folding of the Gla domain, and thereby inhibits the exposure of the phospholipid binding site ${ }^{3.4}$.

However, it became clear that descarboxy-osteocalcin, lacking a covalently attached propeptide, is an in vitro substrate for carboxylase capable of binding the enzyme with high affinity. From the results presented in this thesis it appears that descarboxy-osteocalcin binds carboxylase with high affinity at a site distinct from the propeptilde binding site.

\section{Osteocalcin; structure and function}

Osteocalcin is exclusively synthesized by osteoblasts and odontoblasts ${ }^{46,63,137,136}$, and its syrithesis is stimulated by 1,25 -dihydroxy- $\mathrm{D}_{3}\left(1,25(\mathrm{OH})_{2} \mathrm{D}_{3}\right)$ and vitamin $\mathrm{A}$ (as retinoic acid). It is a relatively small ( $5700 \mathrm{Da}$ ), $\mathrm{Ca}^{2+}$-binding protein which consists of 49 amino acid residues. The molecule contains two helices " which the N-terminal "Gla-helix" consists of residues 16-25, whereas a more C-terminal "Asp-Glu-helix" is composed of residues $30-41$. Both helices are stabilized by a disulfide bond between residues Cys23 and Cys-29. The hydrophilic "COOH-terminal beta sheet" extends from residues 42 to 48 , and lies in proximity to the $\mathrm{NH}_{2}$-terminus thus covering the hydrophobic 
backsides of the helices ${ }^{137}$. The helical conformation of the $\mathrm{COOH}$ terminal beta sheet is induced by $\mathrm{Ca}^{2+}$-binding of its three Gla residues, for instance during the absorption of osteocalcin to hydroxyapatite (figure 9$)^{93}$. The Gla residues are located at position 17,21 and 24 , but in man they are only partly carboxylated.

The extent of incomplete $y$-carboxylation in osteocalcin depends strongly on the position of the glutamic acid residue, with $67 \pm 14 \%$ carboxylation at residue $17,88 \pm$ $9 \%$ carboxylation at residue 21 , and $93 \pm 4 \%$ carboxylation at residue 24140 . This incomplete carboxylation probably results in low affinity for hydroxyapatite which may explain why in human bone the concentration of osteocalcin is only $10-20 \%$ of that in other species ${ }^{141}$. Differences observed in the percentage of osteocalcin

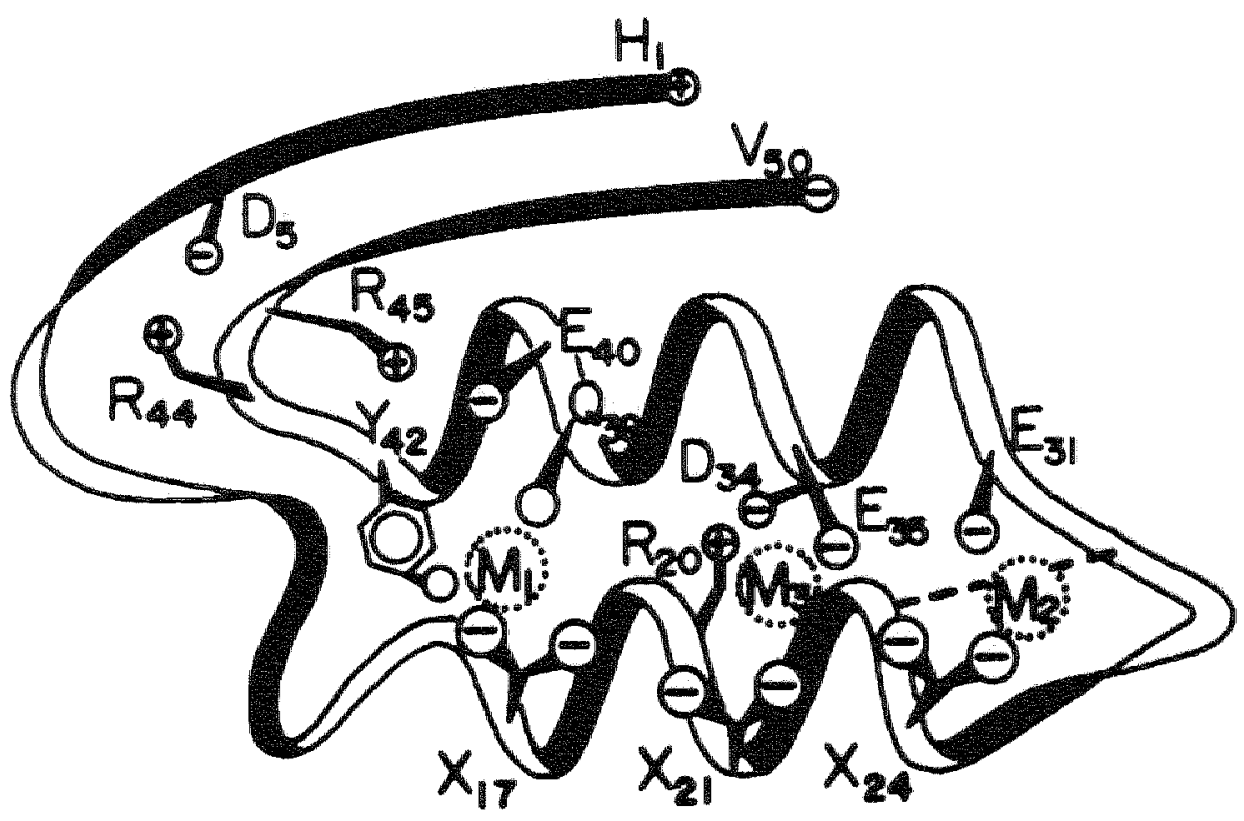

Figure 10: Schematic structure representation of the native chicken osteocalcin molecule $X_{n}, x_{21}$ and $X_{24}$ are the potentially carboxylated Glu residues. Important side chains are labelled in the one-letter code with a subscript indicating their sequence position. $M_{4}$, $\mathrm{M}_{2}$ and $\mathrm{M}_{3}$ represent the probable metal binding siltes. The aromatic thydrocarbons represent possible coordinating oxygen-containing side-chains. The dashed line indicates the disulfide bridge between residues $\mathrm{C}_{23}{ } \mathrm{C}_{29}$. Reproduced from Hauschka and Carr, $1982^{139}$. 
V-carboxylation in bone samples may be caused by individual differences in the efficiency of osteocalcin $\gamma$-carboxylation during synthesis ${ }^{140}$. Osteocalcin was initially thought to function in bone mineralization, but experiments performed by Hauschka and Reid in chickens fed on a vitamin K-deficient diet in combination with vitamin $K$ antagonists showed that $50 \%$ of the bone osteocalcin was lost, but no bone defects were visible ${ }^{142}$. A more prolonged state of vitamin K-deficiency was induced in rats treated according to the warfarin + vitamin $K$ regimen ${ }^{443}$. This resulted in a decrease of bone osteocalcin to not more than $2 \%$ of the normal concentration. After 8 months of treatment the animals displayed increased bone mass in combination with abnormal fusion of the growth-plate and absence of longittudinal bone growth. However, no distinction was made between osteocalcin. MGP or protein $S$ in this experiment, thus the results may also be caused by a decrease in concentration of the latter two proteins. Similar results as found by Hauschka and Reid were obtained by

Ducy et al. ${ }^{63}$, who used osteocalcin deficient mice and found that these animals were normal, viable and fertille. Furthermore these mice had no bone defects at birth and the ultrastructure of the extracellular matrix was normal. However, at 6 months of age increased bone density of the long bones was observed together with increased cortical thickness. Biomechanical measurements of the mutant bones revealed increased bone strength indicating increased bone formation although the number of osteoblasts was comparable to that in control mice. Therefore. Ducy et al. concluded that osteocalcin functions as a negative regulator of bone formation, by limiting bone matrix formation without affecting mineralization or resorption.

\section{Molecular biology and recombinant DNA techniques in vitamin $K$ research}

To study the interactions that take place between carboxylase and its substrates, a large number of substrates have been developed during the past two decades. The first peptides synthesized were short tri- and pentapeptides. They were chosen because (1) they were structural analogs of the natural substrate, (II) they contained Glu residues which might act as $\mathrm{CO}_{2}$ receptors and (III) their synthesis was relatively simple and 
cheap. The main limiting step involving peptide synthesis was the length of the peptide to be synthesized. Longer peptides result in higher costs and more difficulties during syrthesis, protecting, coupling, subsequent cleavage and final deprotection. The short pentapeptides were unsatisfactory when high affinity interactions were to be studied. Therefore the need for longer synthetic peptides rose, especially after the discovery of the propeptide. In 1988 Ulrich et al. were the first to report the synthesis of a high affinity substrate for carboxylase, ProPT-28 ${ }^{129}$. The synthesis of ProPT-28 was a major leap forward in the research on substrate properties of Gla-proteins. However. ProPT28 contained only part of the Gla-domain of prothrombin, and thus could not be used for carboxylation studies on the entire Gla-domain and the effect that this domain might have on the interaction with carboxylase. Here the limitations of peptide synthesis became obvious and a different method of protein synthesis was needed.

In 1990 Wu et al. described the production and subsequent purification of ProlX-59 from $E$. coli ${ }^{93}$. The reason for this approach is that $E$. coli does not posses any posttranslational processing machinery and therefore is unable to carboxylate protein sequences of overexpressed vitamin K-dependent precursor proteins. Therefore the CDNA of the desired precursor protein is ligated into an expression plasmid (figure 10), or vector, after which the construct is introduced (transformed) into competent $E$. coli. The bacterial membranes of these $E$. coll are treated with $\mathrm{CaCl}_{2}$ so that uptake of the modified plasmids is facilitated. An expression vector is a plasmid which not only contains the gene of interest but also contains the necessary regulatory sequences by which expression of the gene can be controlled ${ }^{144}$. Expression vectors furthermore contain an antibiotic resistance gene, which makes the bacteria integrating the vector able to grow on nutrients containing a specific antibiotic agent. This is an easy method to discriminate between $E$. coll that do or do not contain a vector. It is known that $E$. coli can produce large quantities of a desired recombinant protein after the Lac $Z$ promotor, which is present on the plasmid, is induced with isopropyl $\beta-D$ thiogalactopyranoside (IPTG). Depending on the culture conditions, the E. coli strain used and the vector type, up to $12 \mathrm{mg}$ of protein can be purified per liter of culture ${ }^{93}$. An approach to produce recombinant descarboxy-osteocalcin using bacterial 
expression as reviewed in this paragraph is discussed in more detail in chapter 2 , paragraph 2.

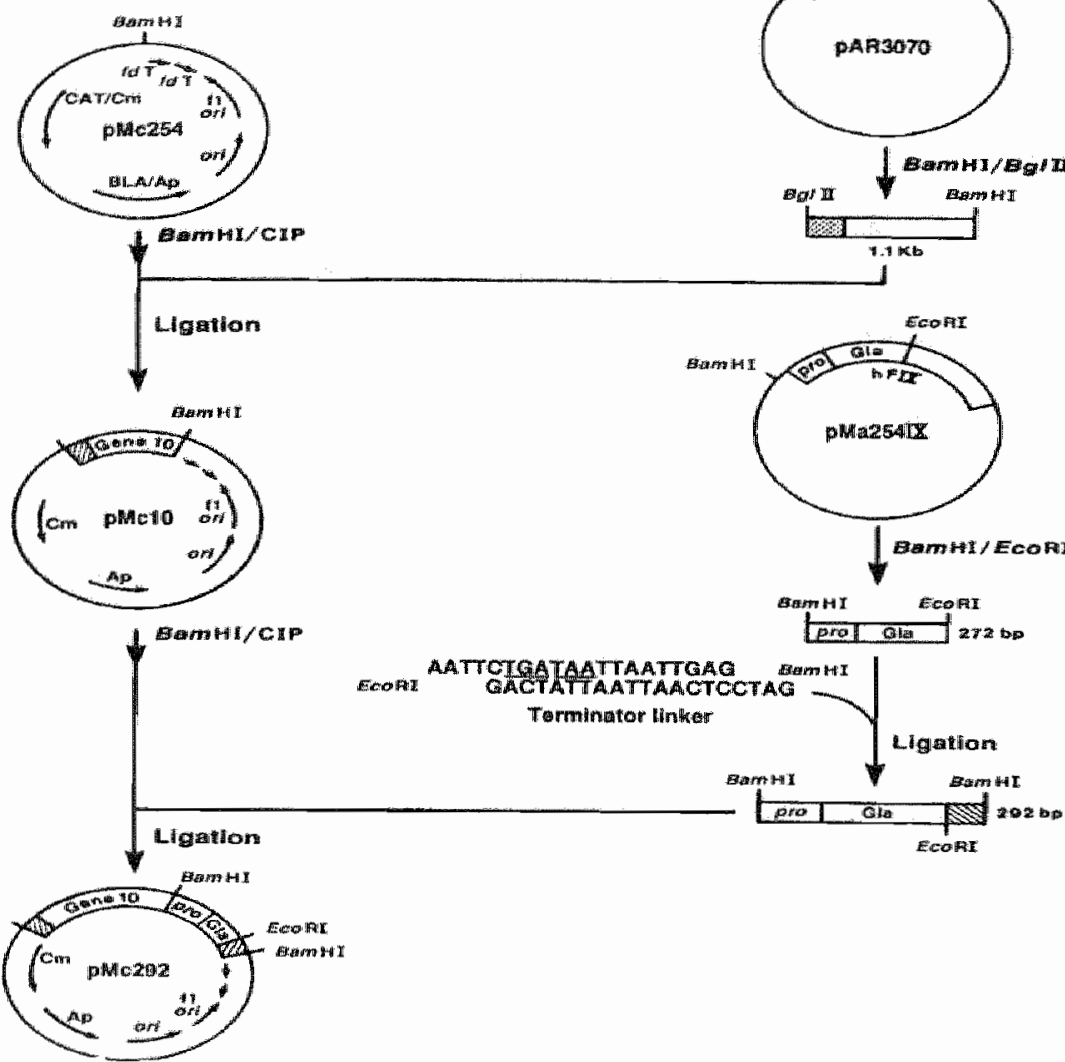

Figure 11 Construction of an expression plasmid containing the complete propeptide and $\mathrm{Y}$ carboxyglutamic acid (Gla) domain sequences of human factor IX. A 1.1-kilobase Bgll-BamHI fragment that contains the promotor sequence and most of the coding region of gene 10 from pAR3070 was ligated into the BamHI site of pMc 254 . Phagemid pMc10, which has the promotor of gene 10oriented opposite to CAT and BLA gene, was chosen to express FIXGla (ProilX-59). A 272-bp BamHI-EcoRI fragment that contains the propeptide and $y$-carboxyglutamic acid domain sequences of human factor IX from a modified factor IX cDNA clone, pMa254IX, was first ligated to a linker containing an EcoRl site at its $5^{\prime}$ end, 2 termination codons, and a BamHI at its $3^{\prime}$ terminus. The resulting 292-bp BamHI fragment was then ligated to the BamHI site of pMc10. Phagemid pMC292, which contains the promotor and most of the sequences coding for gene 10. FIXGla sequence, termination codons and fil ori, was further modified for expressing FIXGla fusion protein by using site-specific in vitro mutagenesis. BLA, B-lactamase; CAT, chloramphenicol acetyltransferase; AP, ampicil in resistance; $\mathrm{CM}_{\mathrm{s}}$ chloramphenicol resistance; $\mathrm{CIP}$, calf intestinal alkaline fosiatase. Reproduced from Wu et al. $1990^{93}$. 


\section{Introduction to this thesis}

Since native osteocalcin purified from bone and subsequently heat decarboxylated is the only known Gla-protein thus far capable of binding vitamin K-dependent y-glutamyl carboxylase with high affinity, without the need for a propeptide, we focussed our attention on this unique protein.

The main goal of this thesis was to study enzyme substrate interactions between descarboxy-osteocalcin (d-OC) or propeptide-containing d-OC (Pro-d-OC) and several other recombinant or organically synthesized substrates and carboxylase. The initial decision was to generate $d-O C$, Pro-d-OC and several mutant forms of both $d-O C$ and Pro-d-OC via recombinant DNA technology. This material could then also be used for other fields of research (e.g. as a protein standard for in vitro diagnostic testkits or as antigen for the generation of antibodies). The production of recombinant osteocalcin in bacteria could provide an unlimited source of the desired protein for the different applications. Several strategies have been developed to produce recombinant osteocalcin both in prokaryotic and eukaryotic cells (chapter 2).

Since the expression of recombinant osteocalcin in $E$. coli resulted in low yields (chapter 2), which were unsuitable for purification- and carboxylation purposes, and because synthesis of polypeptides up to 50 residues became available, we chose to generate both d-OC and carboxylated osteocalcin (OC) via chemical synthesis (chapter 4). Besides both full length $d-O C$ and $O C$, several $d-O C$ and $O C$ derived short peptides were chemically synthesized (chapters $3,4,5$ and 6).

The role of the propeptide and $\mathrm{Y}$-carboxyglutamic acid domain of factor IX and the substrate properties of descarboxy-osteocalcin are discussed in chapters 3 and 4 . In chapter 3, affinity purified bovine carboxylase is used to study enzyme substrate interactions. However, this carboxylase preparation contains at least $2 \mu \mathrm{M}$ of propeptide, due to the purification protocol. In the consecutive chapters recombinant human purified carboxylase expressed in insect cells was available. This carboxylase preparation is free of propeptide and thus became the enzyme of choice for our research regarding the substrate properties of osteocalcin. Because of the poor yields of bacterially synthesized osteocalcin, both organically synthesized full length 
asteocalcin and descarboxy-osteocalcin have been used in the experiments described in chapters $3,4,5$ and 6 as well as a number of osteocalcin derived peptides.

Since the osteocalcin propeptide is the only known human propeptide which possesses a glycine at position -10 instead of the highly conserved alanine, and because osteocalcin is very sensitive to anticoaglant therapy in vivo, we investigated the affinity of the osteocalcin propeptide and d-OC for carboxylase (chapter 4).

The results found in chapter 4 indicated a possible $d-O C$ binding site on carboxylase, and therefore we studied this hypothesis using unique and highly specific active site inhibitors for carboxylase. In this chapter we demonstrate that our hypothesis concerning osteocalcin binding appears valid (chapter 5). If the binding of $d-O C$ to carboxylase is a specific interaction between the two molecules, the question remains what the requirements for $\mathrm{d}-\mathrm{OC}$ are to bind the enzyme. To investigate what specific $\mathrm{N}$-terminal amino acid residues are necessary for the interaction we have studied the kinetic characteristics of several d-OC peptides with a decreasing length of the $\mathrm{N}$ terminus, and a recombinarit $d-O C$ molecule lacking the last $10 \mathrm{C}$-terminal residues (chapter 6). 


\section{References}

1. Dam, H. Cholesterinstofwechsel in Huhnereiem und Hühnchen. Btochem Z215, 475-492 (1929).

2. Dam, H. The antihaemorthagic vitamin in the chick. Biochem $J 29,1273-1285$ (1935).

3. Schofield, F. W. A brief account of a disease in cattle simulating hemorhagic septicemia due lo feeding sweet clover. Can Vet Res 3, 74-79 (1922).

4. Campbell, M. A. \& Link. K. P. Studies on the hemomhagic sweet clover disease. M. The isolation and crystalization of the hemomagic agent. I Biol Chem $138,21-33(1941)$.

5. Stahmann, M. A. Huebmer. C. F. \& Link, L. P. J Blol Chem 138, 513 (1941).

6. Stenflo, U. A new whanim K-dependent protein. Punfication from bowine plasma and prelimirary characterization. J Biol Chem 251, 355-363 (1976).

7. Price, P. A. Otsuka, A. A. Poser, J. W., Kristaponis, J. \& Raman, N. Characterization of a gamma-carboxyglutamic acid-containing protein from bone. Proc Nat/ Acad Sci USA 73, 1447-1451 $(1976)$.

8. Prowse, C. V. \& Esmouf, M. P. The isolation of a new warfarin-sensitive protein from bovine plasma. Biochem Soc Trans 5, 255-256 (1977).

9. Waker, F. J. Regulation of activated protein $C$ by a new protein. A possible function for bovine protain S. I Biol Chem 255, $5521-5524$ (1980).

10. Price, P. A. Unist, M. R. \& Olawara, Y. Matrix Gla protein, a new gamma-carboxyglutamic acid-containing protein which is associated with the organic matrix of bone. Blochem Blophys Res Commun $117,765-771(1983)$.

41. Manfioletti, G., Brancolini, C., Avanzi, G. \& Schneider, C. The protein encoded by a growth arrest-specific gene (gas6) is a new member of the vitamin $K$-dependent proteins related to protein $\mathrm{S}_{\text {, }}$ a negative coregulator in the blood coagulation cascade. Mal Cell Biol 13, 4976-4985 (1993).

12. Warkany, J. A warfarin embryopathy? Am J Dis Child 129, 287.8 (1975).

13. Lichtenthaler, H. K. in Plant Lipids (ed. Moore, T.) 421-464 (CRC Press Inc, Boca Raton, 1993).

14. Allison, A. C. Danger of vitamin K to newborn. Lancet, 1: 669 (4955).

15. Meyer, T. C. \& Angus, U. The effect of large doses of "sylukavit' in the newborn. Arch Dis Chila 31. $213-215(1956)$.

16. Wang, Z., Wang. M., Finn, F, Car, B. I. The growth inhibitory effects of viltamins K and their actions on gene expression. Hepatology 22, 876-882 (1995).

17. Venugopal, M. et al. Symergistic antitumor activity of witamins $C$ and $K 3$ on human urologic tumor call lines. Life Sei $59,1389-1400(1996)$.

13. Venugopal, M. et al. Synergistic antitumour activity of vitamins $C$ and $K 3$ against human prostate carcinoma cell lines. Cell Biol int 20,787-797 (1996).

19. Ervin, E. el al. Characterization of the early events in vitamin $C$ and $k 3$-induced death of human bladder tumor cells. Scanning 20, 210-211 (1998).

20. Hu, O. Y. Wu, C. Y. Chan, W. K. \& Wu, F. Y. Determination of anticancer drug vitanin Ka in plasma by high-performance liquid chromatography. U Chromatogr B Biomed Appl 666, 299-305 (1995).

21. Hemker, H. C. Velthamp, J. J. Hensen, A. \& Loeliger, E. A. Nature of prothrombin synthesils: 
preprothrombinaemia in vitamin K-defictency. Nature 200, 589-590 (1963).

22. Ganrot, P. O. \&. Nilehn, J. E. Plasma prothrombin during treatment with Dicumarol. I1. Demonstration of an abnormal prothrombin fraction. Scand I Clin Lab Invest 22, 23m28 (1968).

23. Josso, F., Lavergne, J. M. Gouault, M. Prou-Wartelle, O. \& Soulier, J.P. Marious molecular states of factor II (prothrombin). Their study by means of staphylocoagulase and anti-factor II antibodies. I.

Factor il in patients treated with vitamin $K$ antagonists]. Thromb Diath Haemorh 20, 88-98 (1968).

24. Stenflo, J., Feriund, P., Egan, W. \& Roepsionff, P. Vitamin K dependent modifications of glutamic acid residues in prothirombin. Froc Natl Acad Sci USA 71, 2730-2733 (1974).

25. Melsestuen, G. L., Zytkovicz, T. H. \& Howard, J. B. Gamma-carboxyglutamic acid: identification and distribution in vitamin K-dependent proteins. Mayo Clin Proc 49, 941-944 (1974).

26. Gaudenack, G. \& Prydz.H. Studies on PIVKA-X. Thromb Dlath Haemorth 34, 455-464 (1975).

27. Mcintosth, J. M. Olivera, B. M., Cruz, L. J. \& Gray, W. R. Gamma-carboxyglutamate in a neuroactive toxin. I Biol Chem 259, 14343- 44346 (1984).

28. Olivera, B. M. Mclntosh, J. M. Cruz, L. J. Luque, F. A. \& Gray, W. R. Purification and sequence of a presynaptic peptide toxin from Conus geographus venom. Biochemistry 23, 5087-5090 (1984).

29. Kulman, J. D. Harris, J. E., Haldeman, B. A. \& Davie, E. W. Primary structure and tissue distribution of wo nowal proline rich gamma carboxyglutamic acid proteins. Proc Natl Acad Sci USA 94, 9058.9062 (199).

30. Berkner, K. L. \& Pudota, B. N. Vitamin K-dlependent carboxylation of the carboxylase. Proc Nath Acad Sci USA 95, 466-471 (1998).

31. Morris, D. P.. Stevens, R. D. Wright, D. J. \& Stafford, D. W. Processive post-translational modification. Vitamin K-dependent carboxylation of a peptide substrate. J Biol Chem 270, $30491-30498$ (1995).

32. Dowd, P., Hershline, R., Ham, S. W. \& Naganathan, S. Vitamin K and energy transduction: a base sirength amplification mechanism. Science 269, 1684-1691 (1995).

33. Furie, B. C. \& Furie, B. Structure and mechanism of action of the vitamin K-dependent gamma-glutamyl carboxylase: recent advances from mutagenesis studies. Thromb Haemost 78, 595-598 (1997).

34. Furie, B. Bouchard, B. A. \& Furie, B. C. Vitamin K-Dependent Biosynthesis of gamma-Carboxyglutamic Acid. Blood 93, 1798-1808 (1999).

35. Olson, J. A. Recommended dietary intakes (RDI) of vitamin $K$ in humans. Am J Chin Nutr 45, 687-692 (1987).

36. Suttie, J. W., Murnmah Schendel, L. L., Shah, D. V., Lyle, B. J. \& Greger, J. L. Vitamin K deficiency from dietary vitamin $K$ restriction in humans. Am J Clin Nutr 47, 475-480 (1988).

37. Cain. D., Hutson, S. M. \& Wallin, R. Assembly of the warfarin-sensitive vitamin K 2,3-epoxide reductase enzyme complex in the endoplasmic reticulum membrane. I Biol Chem 272, 29058-29075 (1997).

38. Guenthner, T. M. Cai, D. \& Wallin, R. Co-purfication of microsomal epoxide hydrolase with the warfarin- sensitive witamin $K 1$ oxide reductase of the vitamin K cycle. Biochem Pharmacol 55, $169-175$ (1998)

39. Wallim, R. \& Martin, L.F. Warfarin poisoning and vitamin $K$ antagonism in rat and human liver. Design of a system in vitro that mimics the siltuation in wivo. Biochem $J 241,389-396$ (1987).

40. Fasco, M. J., Hildebrandt, E. F. S Suttie, J.W. Evidence that warfarin anticoagulant action irwolves two 
distinct reductase activities. J Buol Chem 257, 11210-11212 (1982).

41. Sutte J. W. The biochemical basis of wartarin therapy. Aow Exp Med Brol 214, 3-16 (1987).

42. Katayama, $K$, t al. Comparison of amino acid sequence of bovine coagulation Factor $1 \times$ IChristmas Factor) with that of other witamin K-dependent plasma proteins. Proc NaUl Acad SCI USA 76, 4990-4994 (1979).

43. Davil, E. W. \& Fujikawa. K. Basic mechanisms in blood coagulation. Annu Rev Biochem 44,799-829 $(1975)$.

44. Di Scipio, R, G. Hermodson, M. A., Yates, S. G. \& Davie, E. W. A comparison of human prothrombin, factor $X$ (Christmas factor), factor $X$ (Stuart factor), and protein $S$. Biochemistry 16, 698-706 (1977).

45. Luo, $G_{\text {n }}$ et al. Spontaneous calcification of arteries and cartilage in mice lacking matrix GLA protein. Mature $385,78-81(1997)$.

46. Wolf, $G$. Function of the bone protein osteocalcin: definitive ev/ldence. Nutr Rev $54,332-333(1996)$.

47. Nakano, T. et all. Vascular smooth muscle cell-derived, Glawcontaining growth-potentiating factor lor" Ca(2+) mobilizing growth factors. J Biol Chem 270, $5702-5705(1995)$.

4B. Li. R. et al. Identification of Gas6 as a growth factor for human Schwann cells. J Neurosci 16 , $2012-2019(1906)$.

49. Magnusson, S., Sotrup Jemsen, L., Petersen, T. E., Morris, H. R. R Dell, A. Primary structure of the vitamin K-dependent part of prothrombin. FEBS Lett 44, 199-193 (1974).

50. Dahlback, B. Smith, C. A. Multer-Eberhard, H. J. Visualization of human C4b-binding protein and its complexes with vitarmin K-dependent protein S and complement protein C4b. Proc Nall Acad Sci USA $80,3461-3465(1983)$

51. Maillard, C., Berruyer, M., Serre, C. M., Dechavanne, M. \& Dielmas, P. D. Protein-S, a vitamin K-dependent protein, is a bone matrix component synthesized and secreted by osteoblasts. Endocrinology 130, 1599-1604 (1992).

52. Pan, E., Gomperts, E. D. Millen, R. \& Gilsanz, V. Bone mineral density and its association with inherited protein S deficlency. Thromb Res 58, 221-231 (1990).

53. Nakamura, Y. S. et. al. Tyro 3 receptor tyrosine kinase and its ligand, Gas6, stimulate the function of osteociasts. Sten Cells $16,229-238$ (1998).

54. Hogg. P. J. \& Stenfio, ل. Interaction of vitamin K.dependent protein $Z$ with thrombin. Consequences for the amidolytic activity of thrombin and the interacton of thirombin with phospholipid vesicles. $J$ Biof Chem 266; $10953-10958(1991)$

55. Gijsbers, B. L., van Haarlem, L. J., Soute, B. A. Ebberink, R. H. \& Vemer, C. Characterization of a Gila-containing protein from calcified human atheroscilerotic plaques. Anteriosclerosis 10, $991-995$ (1990).

56. Lewy, R. J., Lian, J. B. \& Gallop. P. Atherocallotn, a gamma-carboxyghtanic acio containing prototr from atherosclerotic plaque. Biochem Biophys Res Commun $91,4 \|-49(1979)$.

57. Lian, J. B. Prien, E. L., Jr., Glimcher, M. J. Gallop, P. M. The presence of protein-bound gamma-carboxyglutamic acid in calcium-containing renal calliculi. A Chn Invest $59,1151-1157$ (1977).

5a. Hauschika, P. W., Friedman. P. A. Traverso. H. P. \& Gallop. P. M. Witamin K-dependent gamma-carboxyglutamic acid formation by kidney microsomes in vitro. Biochem Elophys Res Comumun 
$71.1207-1213(1976)$

59. Nakagawa, Y., Abram, V., Kezdy, F. J., Kaiser, E. T. \& Coe, F. L. Purification and characterization of the principal inhibitor of calcium oxalate monohydrate crystal growth in human urine. $J$ Biol Chem 258. $12594-12600$ (1983).

60. Hauschka, P. W. Lian, J. B. \& Gallop. P. M. Direct identification of the calcium-binding amino acid. gamma-carboxyglutamate, in mineralized tissue. Proc Nav Acad Sci US.A.72, 3925-3929 (1975).

61. Price, P. A. \& Baukol, S. A. 1,25-Dihydroxyvitamin D3 increases synthesis of the vitamin K-dependent bone protein by osteosarcoma cells. I Biol Chem 255,11660 -11663 (1980).

62. Weinreb, M. Shinar, D. Rodan, G. A. Different pattern of alkaline phosphatase, osteopontin, and ositeocalcin expression in developing rat bone visualized by in situ hybridization. $J$ Bone Miner Res 5 , $831-842(1990)$.

63. Ducy, P. et al. Increased bone formation in osteocalcin-deficient mice. Nature 382, 448-452 (1996).

64. Fraser, J. D. \& Price, P. A. Lung, heart, and kidney express thigh levels of mRNA for the vitarin K-dependent matrix Gla protein. Irmplications for the possible functions of matrix Gla protein and for the tissue distribution of the gamma-carboxylase. J Biol Chem 263 "11033-1106 (1988).

65. Otawara, $Y$. \& Pfice, P. A. Developmental appearance of matrix. GLA protein during calcification in the rat. $J$ Biol Chem 261, 10828-10832 (1986),

66. Price, P. A., Faus, S. A. \& Williamson, M. K. Warfarin causes rapid caicification of the elastic lamellae in rat arteries and heart walves. Arterioscler Thromb Vasc Blol 18, 1400-1407 (1998).

67. Price, $P$. A. \&aneda, $Y$. Vitamin $K$ counteracts the effect of warfarin in tiver but not in bone. Thromb Res 46, 121-131 (1987).

68. Nagata, $K$. et al. Identification of the product of growth arrest-specific gene 6 as a common ligand for Axl, Sky, and Mer receptor tyrosine kinases. J Biol Chem 271, 30022×30027 (1996).

69. Chen, J. Carey, K. \& Godowski, P. J. Identification of Gas6i as a ligiand for Mer, a neural cell adhesion molecule related receptor tyrosine kinase implicated in cellular transformation. Oncogene 14, 2033-2039 (1997).

70. Nakano, $T$, et al. Requirement of gamma-carboxyglutamic acid residues for the biological activily of Qas6: contribution of endogenous Gas6 to the proliferation of vascular smooth muscle cells. Bicchem $J$ 323. 387-392 (1997).

71. Gonuppi, S., Ruaro, E. \& Schneider, G. Gas6, the ligand of Axl tyrosine kinase receptor, has mitogenic and survival activities for serum starved NIH3T3 fibroblasts. Oncogene 12, 471-480 (1996).

72. Wu, S. M., Cheung, W. F. Frazier, D. \& Stafford, D. W. Cloning and expression of the CDNA for human gamma-glutamyl carboxylase. Science 254, 1634-1636 (1991).

73. Rehemtulla, A ef al. In vitro and in wivo functional characterization of bowine vitamin K- dependent gamma-carboxylase expressed in Chinese hamster ovary cells. Proc Nall Acad Sci USA 90, 4611-4615 (1993).

74. Houben, R. J., Soute, B. A. \& Vermeer, C. Assay of vitamin K-dependent carboxylase activity in hepatic and extrahepatic tissues, Methods Enzymol 282, 358-368 (1997).

75. Wermeer, C., Hendrix, H. \& Daemen, M. Vitamin K-dependent carboxylases from non-hepatic tissues. FEBS Lett 148, 317-320 (1982) 
76. Buchthal, S. D. \& Bell, R. G. Vitamin K dependent carboxylation of glutamate residues to gamma-carboxyglutamate in microsomes from spleen and testes". comparison with liwerr" lung, and kidney. Biochemisty 22, $1077-1082(1983)$.

77. de Boer wan den Berg, M. A., Uitendaal M. P. Vermeer, C. Direct measurement of vitamin K-dependent enzymes in various isolated and cultured tumor and non-tumor cells. Mol Cell Biochem $75,71-76(1987)$

78. de Boer wan den Berg. M. A., Verstjnen, C. P. \& Vermeer, C. Vitamin K-dependent carboxylase in skit. I Invest Dermatol $87,377-380(1986)$.

79. KuO, W. H. Stafford, D. W. Cruces, J., Gray, w. Solera, d. Chromosomal localization of the gamma-glutamyl carboxylase gene at 2p12. Genomics 25, 746-748 (1995).

80. Wu, S. M. et al. Genomic sequence and transcription start site for the human gamme-glutamyl carboxylase. Blood $89,4058-4062$ (1997).

81. Price, P. A. W. Williamson, M. K. Substrate recognition by the vitamin K-dependent gamma-glutamyl carboxylase: identification of a sequence homology between the carboxylase and the carboxylase recognition site in the substrate. Protein Sci $2,4987-1988(1993)$.

82. Kuliopulos, A, Cleurzo, C. E., Furie, B., Furie, B. C. Walsh, C. T. N-bromoacetyl-peptide substrate affinity labeling of vitamin $K$ dependent carboxylase. Biochemistry $31,9436-9444(1992)$.

83. Kuliopulos, $A_{n}$ et al. Localization of the affinity peptidensubstrate inactivator site on recombinant vitamin Kudependent carboxylase. J Bjol Chem 269, 21364-21370 (1994).

84. Yamada, M. et al. Localization of the factor IX propeptide binding site or recombinant vitamin $K$ dependent carboxylase using benzoylphenylalanine photoaffinity peptide inactivators. Biochemistry 34. $481-489(1995)$.

85. Sugiura, I., Furie, B., Walsh, C. T. \& Furie, B. C. Profactor IX propeptide and glutamate substrate binding sites on the vitamin K-dependent carboxylase Ielentified by site-directed mutagenesis. $J$ Biol Chem $274,17837-17844$ (1996).

86. Wu, S. M. Mutucumarana, V. P., Geromanos, S. \& Stafford, D. W. The propeptide binding site of the bovine gamma-gllutamyl carboxylase. I Biol Chem 272, $11718-11722(1907)$.

87. Mallet, M. Morris, D., Gaudry, M. \& Marquet, A. The active site reglon of the witamin th-dependent carboxylase includes both the amino-teminal hydrophobic and carboxy terminal hydrophilic domaing of the protein. FEBS Lett 413, -6 (1997).

88. Girardot, J.M. Vitamin K-dependent carboxylase. Partial purification and properties of the enzyme-substrate complex. J Brol Chem 257, 15008-15011 (1982).

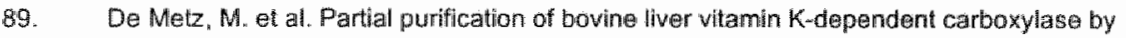
immunospecific adsorption onto antifactor X. FEBS Lett 123, 215-218 ( 1981$)$.

90. Hubberd, B. R. el al. Vitamily K-dependent carboxylase; affinity purification from bowne liwer by using a synthetic propeptide containing the gammamcarboxylation recognition site. Proc NaU Acad Sci USA 86. $6893-6897$ (1989).

91. Harbeck. M. C., Cheung, A. Y. \& Sutte, J. VW. Witamin K-clependent carboxylase partal purification of the anzyme by antibody affinity techniques. Thromb Res 56, 317-323 (1989). 
vitamin K-deipendent carboxylase. Prow Natl Acad Sci USA 88, 2236-2240 (1991).

93. Wu, S. M., Soute, D. A., Vormeer, C. \& Stafford. D. W. In vitro ganma-carboxylation of a 59-fiesidue recombinant peptitde including the propepinde and the gamma-carboxyglutamic acid domain of coagulation factor IX. Effect of mutations near the propeptide cleavage sile. J Bio Chem 265. $13124-13129(1990)$.

94, Wu, S. M. Mutucumarana, V. P. \& Stafford, D. W. Purfication of gamma-glutamyl carboxylase trom bowine liver. Methods Enzymol 282, 346-357 (1997).

95. Berkner, K. L. M. McN Nally, B. A. Purification of vitamin K-dependent carboxylase from cultured cells. Methods Enzymol 262, 313333 (1997).

96. Furie, B. C et al. Purtication of native bovine carboxylase and expression and purification of recombinant bovine carboxylase. Methods Enzymol 282, 333-46 (1997).

97. Shak, D. V. Sutte, J. W. The whamin K dependent, in vitro production of prothrombin. Biochem Biophys Res: Commun 60, 1397-1402 (1974).

98. Sadowski, J, A. Esmon, C. T. \& Suttie, J. W. Vitamin K-dependent carboxylase. Requirements of the rat liver microsomall enzyme system. I Biol Chem 251, 2770-2776 (1976).

99. Suttio, J. W. Esmon, C. T. \& Sadowski, U. A. The witamin K-dependent incorporation of H $\mathrm{H}^{4} \mathrm{O}_{3}$, into prothrombin. pp. 154-5. In: Reich E, al "ed. Proleases and biological control Cold Spring Harbor, Cold Spring Harbor Laboratory, (1975).

400. Girardot, J. M., Mack, D. O, Floyd, R. A. \& Johnson, B. C. Evidence for vitamin K semiquinone as the functional form of vitamin $K$ in the liver viltamin $K$-dependent protein carboxylation reaction. Biochem Biophys Res Commun 70, 655-662 (1976)

101. Friedman, P. A. \& Shia, M. Some characteristics of a vitamin K-dependent carboxylating system from rat Uiver microsomes. Biochem Biophys Res Commun 70, 647-654 (1976).

102. Suttie, J.W. Hageman, J. M. Vitamin K-dependent carboxylase. Development of a peptide substrate. Biol Chem 251, 5827-5830 (1976).

103. Sotte, B. A., Vermeer, C., De Metz, M., Hemker. H. C. \& Lijnen, H. R. In vitro prothrombin synthesis from a purifed precursol protein. Hil. Preparation of an acid-soluble substrate for vitamin K-dependent caboxylase by limited proteolysis of bovine descicarboxyprothrombin. Blochim Biophys Acta 676 , $101-107(1081)$.

104. Vermerer, C., Soute, B. A., Mendrix, H. \& de Boer van den Berg. M. A. Decarboxylated bone Glamprotein as a substrate for hepatic vitamin K-dependent camboxylase. FEBS Let 165 "10-20 (1984).

105. Engelka, J. A. Hale, J. E. Suttie, J. W. \& Price, P. A. Vitamin Kadependent carboxylase: utilization of decarboxylated bone Gla protein and matrix Gla protein as substrates. Blochim Biophys Acta 1078 . $31-34(1991)$

106. Jorgensen, M. J, et al. Recognition site directing viltamin Kudependent gamua-carboxylation resides on Whe propeptide of factor $1 X$. Cell $48,485-19(1987)$.

107. Foster. D. C . at al. Propeptide of human protein C is necessary for gamma-carboxylation. Biochemistry $26.7003-7011(1987)$

408. Knobloch, J. E. Suttie, J. W. Vitamin K-dependent carboxylase. Control of enzyme activity by the "propeptide" region of factor $X$. J Biol Chem 262, 15334-15337 (1987). 
109. Price, P. A. Fraser, J. D. \& Metz Virca, G. Molecular cloning of matrix Gla protein: implicatons lor Sibstrate recognition by the wttamin K-dependent gamma-carboxylase. Proc Nath Acad Saj USA B4. $8335-8339(1987)$.

110. Diuguid, D. L., Rabiet, M. J., Furie, B. C., Liebman, H. A. \& Furie, B. Molecular basis of hemophilla B: a defectiwe enzyme due to an unprocessed propeptide is caused by a pont mutation in the factor IX precursor. Proc Nati Alcad Sai USA 83, 5803-5807 (1986).

111. Bentley, A. K., Rees, D. J., Ruzza, C. B Brownles, G. G. Defective propeptide processing of blood clotting factor $X$ caused by mutation of arginine to glutamine at position -4 . Cell $45,343-348$ (1986).

112. Ware. J. et al. Factor IX San Dimas. Substitution of glutamine for Arg 4 in the propeptide leads to incomplete gamma-carboxylation and altered phospholipid binding properties. J Biol Chem 264. $11401.11406(1989)$

113. Degen, S. A. MacGüliway, R. T. \& Davie, E. W. Characterization of the complementary deoxyribonucleic acid and gene coding for human prothrombin. Blochemistry 22, 2087-2097 (1983).

114. MacGilliwray, R. T. \& Davie, E. W. Charactenization of bovine prothrombin mRMA and its transtation product. Biochemistry 23, 1626-1634 (1984).

115. Fung. M. R. Campbell, R. M. \& MacGillivray, R. T. Elood coagulation factor X mRNA encodes a single polypeptide chain containing a prepro leader sequence. Nucleic Acids Res 12, 4481-4492 (1984).

116. Fung, M. R. Hay, C. W. \& MacGillivray "R. T. Characterization of an almost fullilength cDNA coding for muman blood coagulation factor $X$. Proc Nall Acad Sci USA 82, 3591-3595 (1985).

117. Berkner, K. et al. Isolation and expression of cDNAs encoding lumam factor VII. Cold Spring Harb Symp Quant Blol $51,534-541$ (1986).

118. Long, G. L. Belagaje, R. M. \& MacGillivray, R. T. Cloning and sequencing af I ver cDNA coding for bowine protein C. Proc Natl Acad Sci USA 81, 5653-5656 (1984).

119. Foster, D. C., Yoshitake, S. \& Davie, E. W. The nucleotide sequence of the gene for humen protein C. Proc Natl Acad Sci USA 82, 4673-4677 (1985).

120. Beckmann, R. J. et al. The structure and evolution of a 461 amino acid human prottein $C$ precursor and ils messerigei RNA, based upon the DWA sequence of cloned human liver cDNAS. Nublotic Acids Res $13.5233-5247(1985)$.

121. Dahlback, B., Lundwall, A. \& Stenflo, J. Primary structure of bovine vilamin K-dependent protein s. Proc Nall Acad SCI USA 83,4199-4203 (1986).

122. Lundwall. A et al, Isollation and sequence of the CDNA for human protein S, a regulator of blood coagulation. Proc Nat Aca d Sci USA 83,6716-2670 (1986).

123. Pan, L. C. Wiliamson, M. K. \& Pice, P. A. Sequence of the precursor to rat bone gamma-carboxyglutamic acid proten that accumulates in warfarin-treated osteosarcona cells. I Biol Gham 260, 13398-13401 (1985).

124. Pan "L. C. \& Price "P. A. The propeptide of rat bone gamma-carboxyglutamic acid protein shares homology with other vitamin K-dependent protein precursors. Proc Nath ACad Sci USA B2, 6109-6113 (1985)

125. Doolittle, R. F. Feng, D. F. \& Johnson, M. S. Computer-based characterization of epldermal grownth factor precursor. Nature 307, 558-560 (1984). 
126. Price. P. A. Willamson, M. K. Primary structure of bovine matrix Gla protein, a new vitamin K-dependent bone protein. J Elot Chem $260,14971-14975$ (1985).

127. Celesta, A. J. et al. Isolation of the humar gene for bone gla protein utizing mouse and rat cDNA clones. Embo of $5,1885-1890$ (1986).

128. Cheung, A, Engake, J. A., Sanders, C. \& Sutte, J. W. Vitamin K-dependent carboxyase: influence of the "propieptide" region on mzyme activity. Arch Biochem Biophys 274, 574-581 (1989).

129. Uirich, M. M. Furie, B., Jacobs, M. F., Vermeel, C. \& Furie, B. C. Vitamin K-dependent carboxylation. A synthetc peptide based upon the gamma-carboxylation recognition site sequence of the prothrombin propeptide is an active substrate for the carboxylase in vitro. J Biol Chem 263, 9697-9702 (1988).

130. Fune, B. C. ef al. The ganma-carboxylation recognition sitte is sufficient to direct vitamin K-dependent carboxylation on an adjacent glutamatemich region of thrombin in a propeptide thromibin chimera. $I$ Biof Chem 272, 28258-28262 (1997).

131. Benton, M. E.,Pricie, P. A. \& Suttie, J. W. Multi-site-specificity of the vitamin Kadependent carboxylase: in vitro carboxylation of des-gamma-carboxylated bone Gla protein and Des-gamma-carboxylated pro bone Gla protein. Biochemistiy $34.9541-9551$ (1995).

132. Hubbard, B. R. et al. Vitamin K-dependent cartwoxylation. In witro modification of synthetic peptides containing the garrima-carboxylation recognition site. J Biol Chem 264, 14145-14150 (1989).

133. Soute, B. A. et al. Congenital deficiency of all vitamin K'-dependent blood coagulation factors due to a defective vitamin K-upendent carboxylase in Devon Rex cats. Thromb Hemost 69, 521-525 (1992).

134. Stantey, T. B., Wui, S. M., Houben, R, Mutucumarana, V. P. \& Stafford, D. W. Role of the propeptide and gamma-glutamic acid domain of faction $\mathrm{IX}$ for in vilro carboxylation by the vitamin Ki-dependent carboxylase. Blochemistry 37, 13262-13268 (1998).

135. Wastey, L. C., Rehemtulla, A. Bristol, J. A. 2 Kaufman, R. J. PACElturin can process the vitamin K-dependent pro-factor IX precursor within the secretory pathway. J Bior Chem 268, 8458-65 (1993).

136. Bristol, J. A, Furie, B. C. \& Furie, B. Propeptide processing during factor IX biosynthesis. Effect of point mutations adjacent to the propeptide cleavage site. J Biol Chem 260,7577 7584 (1993)"

137. Hauschka, P. V. Osteocalcin the vitamin K-dependent Ca2+-binding protein of bone matrix. Haemostasis 16, 258-272 (1986).

138. Heertsche, J. N. Reimers, S. M. Wrana, J. L., Waye, M. M. R Gupla, A. K Changes in expression of alpha 1 type 1 collagen and osteocalcim mRlvA in osteoblasts and odontoblasts at different stages of maturity as shown by in stu hybridization. Proc Finn Dent Soc 84, 173-182 (1992).

159. Hauschka, P. V. \& Carr, S. A. Calcium-dependent alpha-helical structure in osteocatcin. Brochemistry $21.2538-2547(1982)$

140. Cairns, J. R. \&.Price, P. A. Direwt domonstration that the vitamen K-dependent bone Gla protein is incompletely gammi-carboxylated in humans. A Bone Miner Res 9, 1989-1997 (1994).

141. Ulich, M. M. W. in Biochemistry "135 (Maastricht University, Maastricht, The Netherlands, 1991).

142. Hauschka, P. V. \& Reid, M. L. Vitamin D dependence of a calcium-binding protein containing gamma-carboxyglitamic acid in chicken bone. S Biol Chem 253,9063-9068 (1978).

143. Price, P. A. Williamson, M. K. Haba, T., Dell, R. B. \& Jee, W. S. Excessive mineralization with growth plate closure in rats on chronic wartarin treatment. Proc Nall ACad Sci USA 79, 7734-7738 (1982). 
14.4. Brock, T. D. \& Madigan, M. T. Elology of Microorganisms fPrentice Hall, Englewood Cllfs. New Jersey. 1988 ) 



\section{Chapter 2}

\section{THE REQUIREMENT OF RECOMBINANT OSTEOCALCIN: POSSIBILITIES, LIMITATIONS AND IN VITRO CARBOXYLATION}

Based on: $\quad$ Roger J.T.J. Houben, Berry A.M. Soute, Marjo H.J. Knapen \& Cees Vermeer (1997); Strategies for developing human osteocalcin standards: a critical evaluation, Scand J Cin Lab Invest, 57 (suppl 227): $100-104$

Roger J.T.A. Houben, Berry A.M. Soute \& Cees Vermeer (1997): Assay of vitamin K-dependent carboxylase activity in hepatic and extrahepalic tissues, Methods Enzymal, 282: $358-368$ 


\section{Introduction to chapter 2}

This more technical chapter describes three main topics all associated with osteocalcin. The requirement for osteocalcin as a standard for in vitro diagnostic tools and the strategy to be used to ensure optimal yields of osteocalcin is discussed in the first paragraph as a spin-off of this thesis.

The second paragraph focusses on the practical implementation of recombinant DNA technology as a tool to produce substantial amounts of osteocalcin. It also discusses the difficulties that were encountered with this technology. Moreover, a balanced discussion is made between the use of recombinant osteocalcin and synthetic osteocalcin for the continuation of this thesis. In the third paragraph the basic characteristics of bovine carboxylase from both hepatic and various extrahepatic tissues are described. The carboxylase preparations from washed microsomes and applications to investigate enzyme substrate interactions is explained. Although in this paragraph several substrates for the carboxylases are discussed "recombinant descarboxy-osteocalcin was not included because it was not available at the time of the study. Therefore, thermally decarboxylated native bovine osteocalcin was used in addition to a variety of both synthetic and recombinant substrates. Although the utilization of washed bovine microsomes as a source of carboxylase is discussed in this paragraph it will not be used in the consecutive chapters, since purified carboxylase became available.

Nevertheless, the methods described in paragraph 2.3 of this chapter are still valid and particularly usefull to study the vitamin $K$ reductases since these enzymes are not present in the purified carboxylase preparations. 



\section{Paragraph 2.1}

THE REQUIREMENT FOR OSTEOCALCIN PROTEIN STANDARDS 


\section{Introduction}

Osteocaicin (also known as Bone Gla Protein, BGP) is a relatively small protein containing 49 amino acid residues ${ }^{1,2}$. During its biosynthesis osteocalicin undergoes three posttranslational carboxylation reactions by which glutamate residues are converted into $\mathrm{y}$-carboxyglutamate (Gla). The conversion of a glutamate residue into Gla is accomplished by the endoplasmic vitamin K-dependent $\gamma$-glutamyl carboxylase, which recognizes its potential substrates by an 18-residues pro-sequence immediately preceding the amino terminus of the mature sequence ${ }^{3,4}$. Since osteocalcin is exclusively produced by osteoblasts (and odontoblasts), its serum concentration is a good marker for bone formation ${ }^{5-7}$. A number of commercial kits are presently available for serum osteocalcin detection, but a drawback is that for a number of reasons welldefined reference material is lacking. This may be one of the reasons why the value obtained for the same serum sample may vary more than 10 -fold, depending on the particular kit used ${ }^{8-10}$. In this paragraph we describe a number of strategies which may be followed for preparing homogenous human osteocalcin, and we will comment on their potential advantages and disadvantages.

\section{Vitamin K-status in elderly women}

As early as in 1984 it was reported that patients with osteoporotic hip fractures had very low circulating vitamin $K$ levels ". This finding was confirmed in a number of subsequent studies ${ }^{1214}$. From epidemiological studies it became clear that the nutritional intake of vitamin $\mathrm{K}$ decreased substantially at increasing age ${ }^{15}$. Finally, using a test based on the differential affinity of carboxylated and undercarboxylated osteocalcin for hydroxyapatite, Knapen et al. demonstrated that vitamin K-deficiency in bone tissue is common among elderly women resulting in increased levels of circulating undercarboxylated osteocalcin ${ }^{16,47}$. In this paper we will refer to undercarboxylated osteocalcin as uCOC (= osteocalcin not bound to hydroxyapatite in the test mentioned above). Szulc et al. showed that serum ucOC is inversely correlated with bone mass ${ }^{18}$ and with fracture risk ${ }^{19}$. 


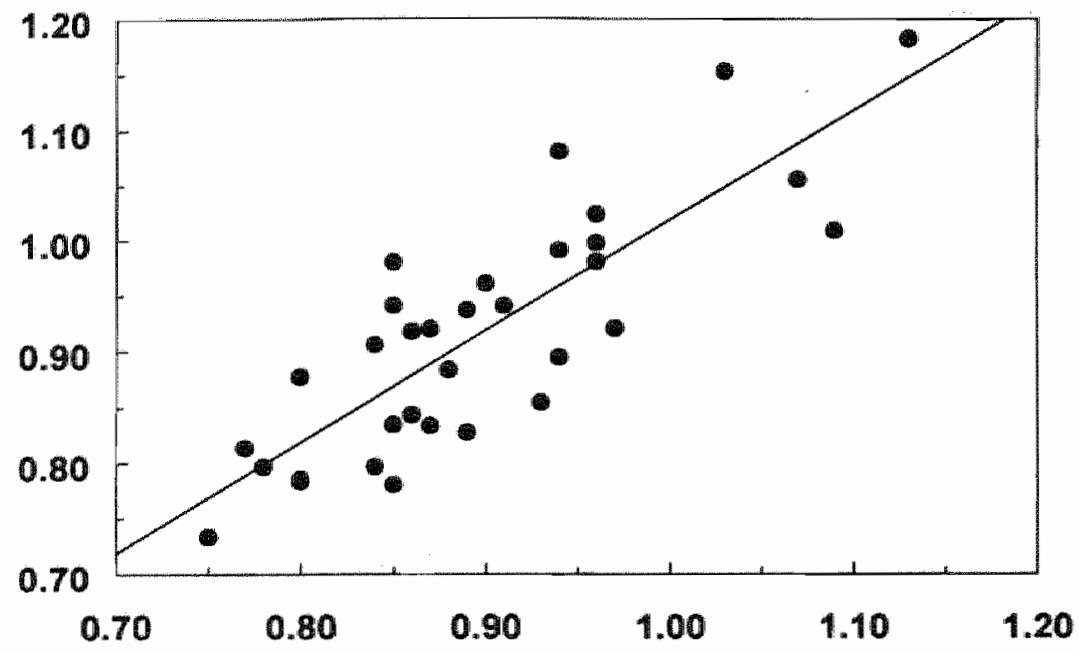

\section{Predicted BMD: right femur neck $(\mathrm{g} / \mathrm{cm} 2)$}

Figure 1: Actual bone mineral density (BMD) as a function of the predicted BMD. Participants in this study were 33 apparantly healthy women, $1-10$ years postmenopausal (as decided from the date of their last menstruation). Bone densitometry of the right femur neck was performed with a lunar DPX-L densitometer, osteocalcin fractions were assessed as described in ${ }^{17}$. Multiple linear regression analysis was used to determine associations between biochemical markers and BMD. Stepwise variable entry showed age and ucOC the only variables to contribute significantly to the bone mineral density in this age group.

We have confirmed these data in a group of 33 women who were 1-10 years postmenopausal. Multiple linear regression analysis showed age and UCOC to be two independent variables both of which were inversely correlated with bone mineral density. Based on the derived equation $\mathrm{BMD}_{\text {pred }}=2.60-0.023 \times$ age $-0.14 \times 4 \mathrm{COC}$ we have calculated the predicted BMD of the right femur neck, which was plotted against the observed BMD (figure 1). The fact that in this study a correlation coefficient of 0.82 was obtained, demonstrates the importance to measure independently both normal osteocalcin and ucOC. Two questions remain to be adressed: a) how do we explain that osteocalcin is the only known Gla-protein which, under normal physiological conditions, is partly synthesized in its desciarboxy form, and b) how to ascertain a sufficient supply of homogenous reference material for both normal ( $3-\mathrm{Gla}$ ) and descarboxy-osteocalcin. 


\section{Role of pro-sequence in substrate recognition by carboxylase}

In all Gla-proteins the presence of the pro-sequence is essential both for in vivo and in vitro carboxylation of protein substrates, and the role of individual amino acids in substrate recognition has been investigated in detail. As seen in figure 2, two amino acid residues are highly conserved in all Gla-proteins: Phenylalanine (Phe) ${ }^{-16}$ and Alanine (Ala) ${ }^{-10}$, and their presence at these positions has been proven critical for carboxylation. Osteocalcin is the only known Gla-protein in which no Ala is found at position -10. The effect of a mutation at this site was first shown in the pro-sequence

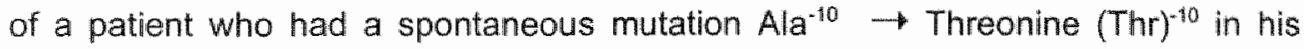
coagulation factor $\mid X$ precursor, which caused an extreme sensitivity to low doses of warfarin, leading to severe haemophilia $B{ }^{20}$. The mechanism underlying this phenomenon turned out to be the 30-fold reduced affinity of the precursor protein for $y$-glutamylcarboxylase, and a similardecrease in affinity was observed for the exchange of $\mathrm{Ala}^{-10}$ by Glycine (Gly) $)^{10}$. Since this is the regular sequence in human osteocalcin, it must be expected that the affinity of osteocalcin precursor proteins for carboxylase is well below that of other Gla-proteins. On the basis of these results it was suggested by Chu et al. that this reduced affinity may result in premature dissociation of the enzyme-substrate complex, and thus in incomplete carboxylation. Obviously, the result of a poor enzyme-substrate affinity will show most clearly during episodes of vitamin Kdeficiency and the use of vitamin K-antagonists, i.e. when competition for the substrate binding site on carboxylase takes place. Indeed it was demonstrated that during very mild oral anticoagulant treatment the inhibitory effect on osteocalcin synthesis is almost maximal, whereas at the same time the caboxylation of prothrombin is hardly affected (M.H.J. Knapen et al, unpublished data). 


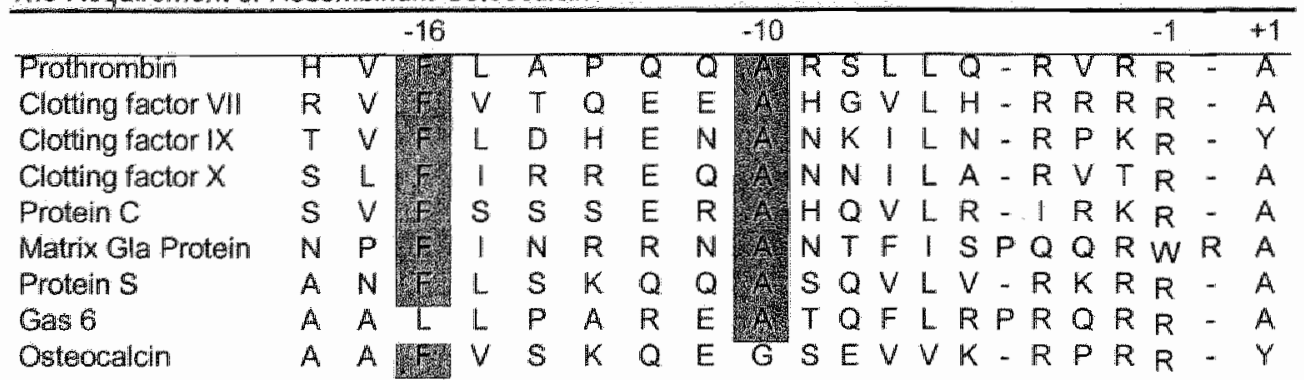

Figure 2: Amino acid sequences in propeptides of human Gla-proteins. The various amino acid residues are denominated according to the one-fetter code. Matrix Gla protein has an internal pro-sequence, which is aligned in such a way to obtain maximal homollogy.

\section{Three strategles for preparing human osteocalcin standards}

For the calibration of osteocalcin test kits it will be essential that carboxylated osteocalcin (3 Gla residues per molecule) and descarboxy-osteocalcin (0 Gla residues per molecule) are available in sufficient amounts. In principle the preparation of these compounds may be performed in three different ways:

\section{A. Isolation from human bone}

Apart from disadvantages such as the difficult preparation procedure, availability of fresh human bone, and risk of spreading infectious diseases, a major drawback to this route is that human bone was shown to contain a mixture of osteocalcins of varying degrees of carboxylation, and that it will be hard to purify these fractions to homogeneity. Notably the Gla residue at position 17 is substantially undercarboxylated ${ }^{21}$, and it has been shown that this residue is critical for the calcium-dependent conformation of osteocalcin 22 .

\section{B. Chemical synthesis}

With the present technical facilities this route is feasible, and - though expensive today it may turn out to be the cheapest way of producing sufficient amounts of standard in the near future. It should be kept in mind, however, that in vivo osteocalcin is synthesized in the form of a pre-pro-protein precursor the conformation of which may 
be different from that of a chemically synthesized polypeptide, even after cleavage of the leader sequence.

\section{Recombinant osteocalcin}

For reasons indicated above it will be crucial to express recombinant human osteocalcin in a eukaryotic carboxylating cell line. Cell lines with a high potential of carboxylating recombinant proteins (e.g. coagulation factors) are presently available ${ }^{23,24}$. By culturing the host cells in the presence of either vitamin K or warfarin, mature osteocalcin in its carboxylated or non-carboxylated form would be obtained respectively. To ensure maximal carboxylation of the recombinant osteocalcin, it seems indicated to prepare by site-directed mutagenesis the modified precursor form Gly ${ }^{-10} \rightarrow$ Ala. Since osteocalcin is neither glycosylated nor phosphorylated in vivo, it is possible to produce descarboxyosteocalcin using bacterial expression in Escherichia coli. This technique has the advantage that it may yield larger quantities of recombinant protein than eukaryotic cell cultures do, because prokaryotes (bacteria) can be grown faster at much higher densities. Another advantage of prokaryotic expression is that the produced osteocaicin is completely non-carboxylated whereas it remains uncertain whether this is the case in eukaryotic cells grown in the presence of warfarin.

From this evaluation it seems that the preparation of carboxylated and noncarboxylated recombinant osteocalcin is an important step in the standardization of the osteocalcin determination. Whether the recombinant product will be structurally similar to native osteocalcin remains to be seen, but the recent expression of fully carboxylated and functionally active recombinant coagulation factors has shown that the proper eukaryotic systems are available now to ensure the large scale production of recombinant Gla-proteins.

As mentioned above, expression of osteocalcin in E.coli is the technique of choice to obtain sufficient amounts of descarboxy-osteocalcin since bacteria lack posttranslational processing. In the next paragraph the construction and production of recombinant descarboxy-osteocalcin and descarboxy-pro-osteocalcin and its limitations 
are discussed. 
Paragraph 2.2

CLONING AND EXPRESSION OF OSTEOCALCIN USING ESCHERICHIA COLI AS A HOST 



\section{Introduction}

The main goal of our efforts was to prepare sufficient amounts of non-carboxylated proosteocalcin and osteocalcin, to identify sequence compositions present within osteocalcin necessary for the recognition and subsequent carboxylation by the vitamin K-dependent $y$-glutamyl carboxylase. We therefore required sufficient osteocalcin of human origin in the the non-carboxylated form.

Because prokaryotes do not possess vitamin K-dependent carboxylase activity, expression of the osteocalcin cDNA will result in descarboxy-(propeptide containing) protein. Furthermore it is possible to introduce mutations in the osteocalcin sequence through molecular biology and thus study the effect of these mutations on the substrate properties of osteocalcin.

The expression of osteocalcin and the additional problems and limitations that were encountered during this process are described in this paragraph.

\section{Synthesis of human (pro)-osteocalcin cDNA}

Human osteoblasts were obtained after bone biopsy and cultured in the presence of $1,25(\mathrm{OH})_{2}$-vitamin $\mathrm{D}_{3}$ until the cells had reached confluency. Cells were grown in RPMI 1640 medium (Flow ICN) supplemented with $2 \mathrm{mM} \mathrm{L-glutamate,} 10 \%$ newborn calf serum (Gibco BRL) and gentamycin (Boehringer) as an antibiotic. Cultures were maintained in a humidified incubator at $37{ }^{\circ} \mathrm{C}$ and $5 \% \quad \mathrm{CO}_{2}$. At confluency (approximately $3 \times 10^{7}$ cells per flask), cells were washed with PBS and harvested.

Cell suspensions ( $10^{8}$ cells) were centrifuged at $1200 \mathrm{rpm}$ for 5 minutes and the cell pellets were stored at $-80^{\circ} \mathrm{C}$ until use. Subsequently cells were thawed and treated with RNAzol B (Campo scientific) according to the manufacturer's protocol ${ }^{25}$. Total RNA was stored at $-20^{\circ} \mathrm{C}$ in $75 \%$ ethanol $(V / V)$ until further use. For the reverse transcriptase (RT) reactions $24 \mu$ l total RNA, $10 \mu 10 \times$ RT buffer (Gibco BRL), and $5 \mu$ loligo(dT) primer (Gibco BRL) were mixed and incubated at $70{ }^{\circ} \mathrm{C}$ for 5 minutes. After rapid cooling on ice, $2 \mu \mathrm{l} 25 \mathrm{mM}$ dNTPs (Pharmacia), $5 \mu \mathrm{l} 0.1 \mathrm{mM} \mathrm{DTT}$ (Gibco BRL), $1 \mu \mathrm{l}$ Rnasin, and $3 \mu \mathrm{l} 200 \mathrm{U} / \mu \mathrm{l}$ M-MLV reverse transcriptase (Gibco BRL) were added in a 
total volume of $50 \mu \mathrm{l}$. The RT reactions were incubated at $37^{\circ} \mathrm{C}$ for 1.5 hour and subsequently stored at $-20^{\circ} \mathrm{C}$ until further use (figure 1). The resulting CDNA's of human osteocalcin and propeptide-containing osteocalcin are indicated as OC and ProOC cDNA, respectively.

MRNA with poly (A) tail
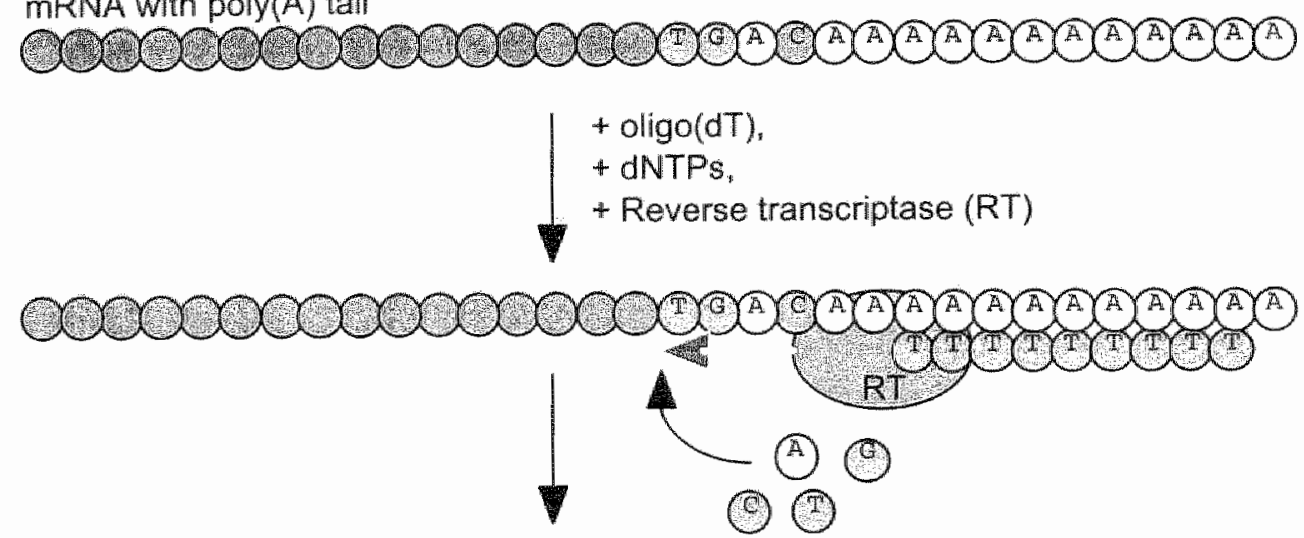

mRNA

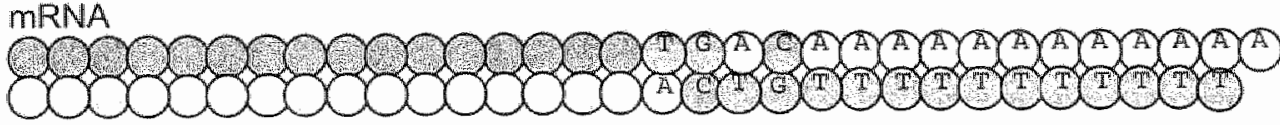
ODNA

Figur 1: Principle of reverse franscriptase (RT) reaction on mRNA to create cDNA. Ohigo dT stands for the primer which binds the poly (A) tract at the $3^{\prime \prime}$ teminus of mRNA's and primes the synthesis of the first strand of CDNA; dNTP's stends for deoxyribonucleoside triphosphates mix consisting of deoxyadenosine (A). deoxycytidine (C), deoxyguanosine (G) and deoxythymidine (T). Pictina by Hown H.M. Spronk.

\section{Construction of expression vectors $\mathrm{PQE} 30-\mathrm{OC}$ and $\mathrm{PQE} 30$ pro-OC}

For cloning and expression of $O C$ and pro-OC cDNA the commercially available QlAexpress system was used (Qiagen $\|$ nc.). To facilitate protein purification by metal cheiate affinity chromatography the recombinant protein was engineered to contain a six residues long histidine tail at the $\mathrm{N}$-terminus. For in frame fusion with the start codon 
of the 6-His region the expression vector pQE30 was linearized with Sphl and Hindlll. Subsequently, the linearized vector was purified by agarose gel electrophoresis according to standard procedures ${ }^{26}$.

For cloning of the human OC and pro-OC CDNA (figure 2), 5'-Sphl and $3^{\circ}$-Hindlll digestion sites were introduced by PCR. Primers prohOC-Sphl and prohoC-Hindlll were used for amplification of pro-OC CDNA and primers OC-Sphl-and OC-Hindill for OC CDNA amplification. Each PCR reaction consisted of $5 \mu \mathrm{cDNA}$ solution, $1 \mathrm{mM}$ of each dNTP, $1 \mu \mathrm{g}$ of each primer, $4 \mathrm{mM} \mathrm{MgCl}, 50 \mathrm{mM} \mathrm{KCl}, 10 \mathrm{mM}$ Tris-HCl pH 8.3 (RT), $0.01 \%$ gelatin, and $2.5 \cup$ Taq polymerase (Pharmacia) in a total volume of $50 \mu l$. Each PCR cycle consisted of 1 minute at $95^{\circ} \mathrm{C}, 2$ minutes at $60^{\circ} \mathrm{C}$ and 2 minutes at $72^{\circ} \mathrm{C}$. After 33 cycles the PCR was terminated by 10 minutes incubation at $72{ }^{\circ} \mathrm{C}$. The amplified CDNA's of $O C$ and pro-OC were both digested with Sphl and Hindlll and the resulting fragments were then separated by agarose gel electrophoresis and isolated by electrolution ${ }^{26}$. The isolated fragments and linearized vector were then ligated in reactions containing $1 \mu$ digested fragment, $1 \mu$ digested pQE30 vector, $1 \times$ T4 DNA ligase buffer, 1 mM ATP, and 1 Weiss unit T4 DNA ligase (Pharmacia). Ligations were performed overnight at room temperature in a total volume of $10 \mu l$. Recombinant plasmids, $\mathrm{PQE} 30-\mathrm{OC}$ and $\mathrm{pQE} 30-\mathrm{pro}-O C$, were transformed into $E$. coll strain M15 ( $\mathrm{Nal}^{\mathrm{s}} \mathrm{Str}^{\mathrm{s}} \mathrm{rif}^{\mathrm{s}}$, lac" ara gal $\mathrm{mtl}^{-} \mathrm{F}^{*}$ recA* uvit) containing the pREP4 vector (Qiagen Inc.). Stable transformants were selected for ampicillin and kanamycin resistance. Final examination for OC or pro-OC CDNA inserts of the ampicillin and kanamycin resistant E. coli was performed through digestion of plasmid constructs with Sphl and Hindlli. 


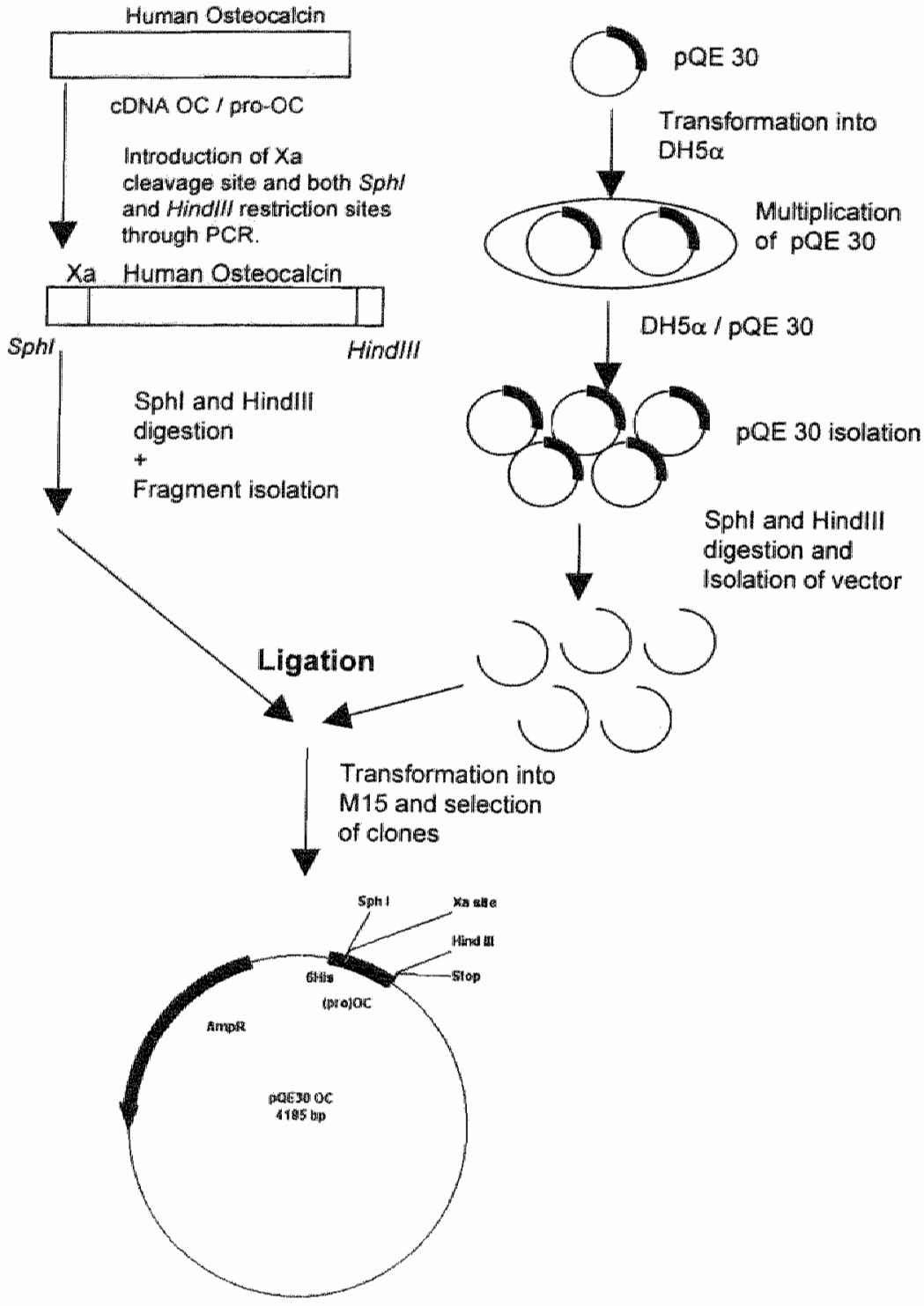

Figure 2: $\quad$ Schematic representation of the cloning of $O C /$ pro-OC into expression vector PQE 30. AmpR stands for the ampicilline resistance gene; 6 His stands for the histidine purification tag. Pictwe by Henti.M.M. Sprank 


\section{Preparation of competent cells}

The desired bacterial strain (M15 [pREP4], Qiagen Inc.) was spread on LB plates containing kanamycin and incubated overnight at $37^{\circ} \mathrm{C}$. A single colony was taken and used to inoculate $50 \mathrm{ml} L \mathrm{LB}$ medium. The culture was shaken at $37^{\circ} \mathrm{C}$ and $250 \mathrm{rpm}$ until an $O D_{550 \mathrm{~nm}}$ of $0.4-0.5$ was reached. After cooling the culture down on ice for 10 minutes, cells were collected by centrifugation at $2500 \times \mathrm{g}$ for 12.5 minutes at $4{ }^{\circ} \mathrm{C}$. The bacterial pellet was resuspended in $16 \mathrm{ml}$ transformation buffer ( $10 \mathrm{mM}$ K-MES pH 6.3, $50 \mathrm{mM} \mathrm{MnCl}_{2}$, and $50 \mathrm{mM} \mathrm{CaCl}$ ). After incubation on ice for 10 minutes, cells were collected by centrifugation at $2500 \times \mathrm{g}$ for 12.5 minutes. The cell pellet was resuspended in $4 \mathrm{ml}$ transformation buffer containing $10 \%(\mathrm{v} / \mathrm{v})$ glycerol. Aliquots of $500 \mu l$ were frozen in liquid nitrogen and stored at $-80^{\circ} \mathrm{C}$ until further use.

\section{Construction of expression vectors pQE40-OC and pQE40-pro-OC}

For the production of $O C$ and pro-OC fusion proteins in $E$. coll, the pQE40 vector (Qiagen Inc.) was chosen. It contains an expression cassette consisting of the phage

T5 promotor fused to the mouse DHFRS protein. To facilitate protein purification by metal chelate affinity chromatography using $\mathrm{Ni}^{2 *}$-NTA resin the recombinant protein was engineered to contain a six residues long histidine tail at the $\mathrm{N}$-terminus. Furthermore, a sequence encoding a methionine residue was introduced $N$-terminal of both the $O C$ and pro-OC sequences between the DHFR sequence and the first amino acid residue of the osteocalcin cDNA's (figure 3). The methionine was introduced to enable cyanogen bromide ( $\mathrm{CNBr}$ ) mediated cleavage of the fusion proteins after purification using metal chelate affinity chromatography, and thus facilitating removal of the fusion protein. For in frame fusion with the start codon of the 6-His region the expression vector PQE40 was linearized with Sphl and Hindlll. Subsequently, the same procedure was followed as for the PQE30-OC-and PQE30-pro-OC constructs, with this respect that the PQE30-OC- and PQE30 pro-OC constructs served as the source of OC and pro-OC CDNA. 


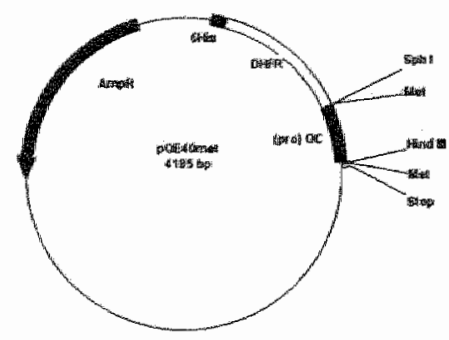

Figure 3: Schematic representation of the PQE 40 wector including the (pro) OC insert

\section{Construction of expression vectors pMALC-OC and pMALc-pro-OC}

$A 5^{\prime}$-end EcoRl and $3^{\circ}$-end HindIII restriction site was added to both $O C$ and pro-OC CDNA's using PCR. This enabled introduction of the CDNA's downstream from the malE gene of E. coli present in the pMALc plasmid (New England Biolabs) (figure 4). The malE gene encodes a maltose-binding protein (MBP), resulting in expression of an MBP fusion protein. Moreover, a sequence encoding a methionine residue was introduced in the same way and for the same purpose as mentioned above. Production and subsequent purification of the fusion protein is obtained after induction of a strong "tac" promoter using IPTG resulting in expression of the cloned cDNA's and a one-step purification of the desired proteins using MBP's affinity for maltose. 


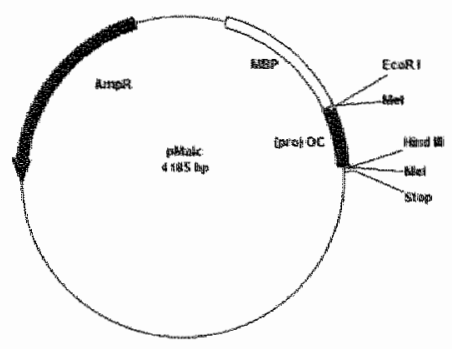

Figure 4: $\quad$ Schematic representation of thepMALc vector including the (pro) OC cDNA.

\section{DNA sequencing reactions}

DNA sequence analyses were performed according to the cycle sequencing procedure developed by Perkin Elmer ${ }^{27,28}$. In brief, approximately $0.2 \mu \mathrm{g}$ of $\mathrm{CsCl}_{2}$ purified DNA was added to a reaction mixture which included $8 \mu$ Terminator Ready Reaction Mix (Perkin Elmer) and 5 pmol primer. The volume was adjusted to a total of $20 \mu \mathrm{l}$ using distilled water. Each cycle consisted of an incubation for 30 seconds at $95^{\circ} \mathrm{C}, 15$ seconds at $60^{\circ} \mathrm{C}$ and 4 minutes at $72{ }^{\circ} \mathrm{C}$. After 25 cycles the cycle sequencing procedure was finished by cooling the reaction down to $4{ }^{\circ} \mathrm{C}$. Subsequently, the extension products were precipitated using ethanol precipitation and purified by spincolumn purification, using Sephacryl S200 columns (Pharmacia Biotech). Samples were dried under vacuum and resuspended in $25 \mu$ l of Template Suppression Reagent (Perkin Elmer). Prior to loading, samples were heated at $95{ }^{\circ} \mathrm{C}$ for 2 minutes and subsequently put on ice. Sequence analysis of the samples on the ABI Prism 310 Genetic Analyzer (Perkin Elmer) was performed according to the manufacturers manual ${ }^{27}$. 


\section{Rapid screening of small-scalle expression cultures}

For production of recombinant proteins $\mathrm{OC}$ and pro-OC, cells $(10 \mathrm{ml})$ were grown in Luria Bertani-(LB) medium until a bacterial density at $A_{600 \mathrm{~nm}}$ of 0.7 was reached. The expression of the recombinant gene was induced by the addition of isopropyl-b-Dthiogalactopyranoside (IPTG) to a final concentration of $2 \mathrm{mM}$. Cultivation was continued for 2,3 or 4 hours. Cells of $1 \mathrm{ml}$ cultures were harvested by centrifugation for 1 minute in a microcentrifuge (13 $000 \mathrm{rpm})$.

\section{A. $p Q E$ constructs}

For $O C$ and pro-OC from either pQE-30 or pQE-40 lysis of the cells was performed using $200 \mu$ B Buffer B ( $8 \mathrm{M}$ urea, $0.1 \mathrm{M} \mathrm{Na-phosphate,} 0.01 \mathrm{M} \mathrm{Tris-HCl} \mathrm{pH} \mathrm{8.0)}$ ). Cellular debris was pelleted by centrifugation for 10 minutes at $10000 \times g$ at $4{ }^{\circ} \mathrm{C}$ and the supernatant was transferred to a fresh tube. To the supernatant $50 \mu \mathrm{l}$ of $50 \%$ slurry of Ni-NTA resin was added and incubated for 30 minutes at RT. After this incubation the suspension was transferred to a spin-column and the resin was washed 3 times with $400 \mu$ Buffer $\mathrm{C}(8 \mathrm{M}$ urea, $0.1 \mathrm{M}$ Na-phosphate, $0.01 \mathrm{M}$ Tris-HCl pH 6.3). Finally the recombinant protein was eluted with $50 \mu$ Buffer $\mathrm{C}$ containing $100 \mathrm{mM}$ EDTA.

\section{B. pMALc constructs}

For $O C$ and pro-OC fusion proteins from pMALc cells were lysed by overnight storage at $-20^{\circ} \mathrm{C}$. Subsequently, the lysed cells are sonicated for 2 minutes on ice. Lysed and sonicated cells are centrifuged at $9000 \times \mathrm{xg}$ at $4{ }^{\circ} \mathrm{C}$ for 20 minutes after which the supernatant (crude extract) is decanted and stored on ice. If the crude extract is to viscous it can be diluted by adding $5 \mathrm{ml}$ Column Buffer $(200 \mathrm{mM} \mathrm{NaCl}, 20 \mathrm{mMTris}-\mathrm{HCl}$, $\mathrm{pH7.4}$ and $1 \mathrm{mM}$ EDTA). To the crude extract $200 \mu \mathrm{l}$ of amylose resin in Column Buffer was added and the mixture was incubated on ice for 15 minutes. After incubation, the resin was spun down in a microcentrifuge for 1 minute and the supernatant was removed and discarded. The pellet was then washed with $1 \mathrm{ml}$ Column Buffer and again centrifuged for 1 minute in a microcentrifuge. Subsequently the resin was resuspended in $50 \mu \mathrm{l}$ SDS-PAGE sample buffer (15\% (v/v) b-mercaptoethanol, $15 \%$ 
(w/v) SDS, $1.5 \%(\mathrm{w} / \mathrm{v})$ bromophenol blue, $50 \%$ (v/v) glycerol). Appropriate aliquots of purified expression samples in SDS-PAGE sample buffer were boiled for 1 minute after which the samples were loaded onto a $10 \%$ SDS-PAA-gel and electrophoresis was carried out under denaturing conditions according to Laemmli ${ }^{29}$.

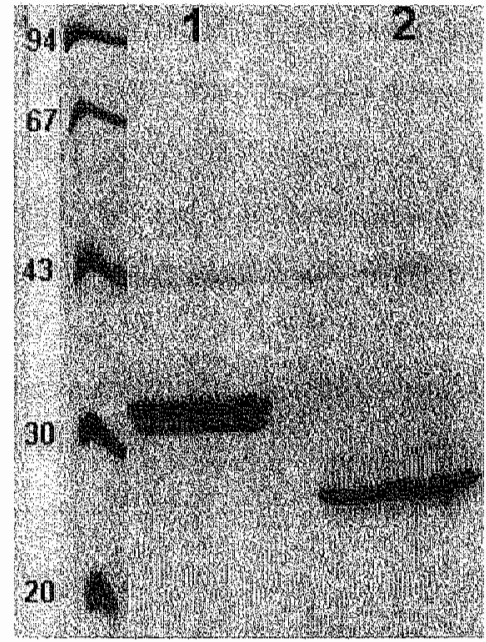

Figure 5: $\quad 10 \%$ reducing SDS gel. In lane 1 DHFR-pro-OC, in lane 2 DHFR-OC. Mollecular mass is shown on the far left.

\section{Western blot analysis of expressed fusion proteins}

For Western blot analysis of recombinant expression proteins osteocalcin (OC) and proosteocalcin (pro-OC), small scale expression cultures were purified as described previously. $20 \mu \mathrm{l}$ aliquots of either $\mathrm{Ni}^{2+}-\mathrm{NTA}$ resin or amylose resin purified expression samples were boiled for 1 minute in $5 \mu$ of SDS-PAGE sample buffer and the samples were loaded onto a 10\% SDS-PAGE gel. Electrophoresis was carried out under denaturing conditions according to Laemmli ${ }^{29}$. After electrophoresis samples were transferred to $0.2 \mu \mathrm{m}$ nitrocellulose (Schleicher \& Schuell) by electroblotting as described by Towbin et al..$^{30}$. Blots were washed for 5 minutes in PBST (phosphate 
buffered saline (PBS) supplemented with $0.1 \%$ (v/V) Tween20) followed by blocking of the nonspecific binding sites by incubation for 1 hour in PBST-buffer supplemented with $3 \%(w / v)$ bovine serum albumin (BSA). Incubation of the blots was performed with a 1:1000 dilution of the appropriate antiserum (anti 1-19 osteocalcin monoclonal antibody, Hoffmann-La Roche) for 1 hour. A secondary monoclonal peroxidase conjugated rabbit anti-mouse antibody (DAKO) was used in a 1:1000 dilution. The blot was incubated for 4 hour. After extensive washing of the blots with PBS, the osteocalcin positive bands on the blot were stained by a reaction with $0.05 \%(w / v) 3,3^{3}$-diaminobenzidine tetrahydrochloride (DAB) (FLUKA) and $0.025 \%(\mathrm{~V} / \mathrm{V}) \mathrm{H}_{2} \mathrm{O}_{2}$ in PBS. The staining process was stopped by washing the blots in water (figure 6 ).

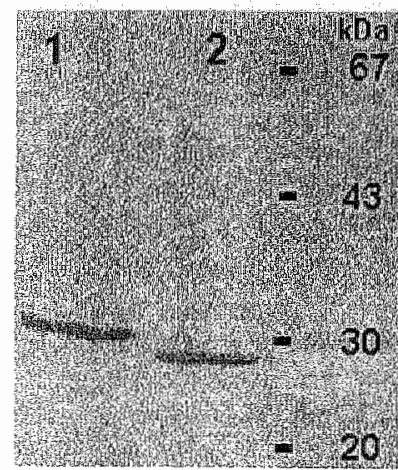

Figure 6: Western blot of DHFR-pro-OC (lane 1) and DHFR-OC (lane 2). Molecular mass is shown on the far right.

\section{Results}

Initially, OC and pro-OC CDNA's were cloned into the expression vector pQE30 to obtain optimal production of the recombinant proteins in E. coll. After stable transformation into E. coli strain M15 [PREP4], expression was induced with $2 \mathrm{mM}$ IPTG. Two and four hours after induction, Ni-NTA-resin purified bacterial culture extracts were analysed using SDS-PAGE. No expression products of either OC or pro- 
OC were detectable after staining the SDS-PAA gels with Coomassie Briljant Blue (CBB) (data not shown). Subsequently, the expression of a DHFRS-6His construct from PQE16 (Qiagen) was performed as a control, together with the PQE30-OC and pQE30pro-OC constructs. After two and four hours post-induction an expression product became visible in the control with an apparent molecular weight of $25 \mathrm{kD}$, indicating expression of DHFR ${ }^{31}$. In both pQE-30-OC and PQE30-pro-OC constructs no band of either OC or pro-OC was visible on SDS-PAA gels after CBB staining. Also analysis of the expressed proteins on Western blot did not reveal any expression of a product that was recognized by anti 1-19 osteocalcin antibodies.

The absence of expression products of both pQE30-OC and pQE30-pro-OC was probably caused by the low molecular weights of the two constructs, 5900 and 7800 Dalton respectively, which makes them susceptible to proteolysis in E. coli. Therefore, the cDNA constructs of both proteins were ligated into the pQE40 expression vector in such a way that both proteins became $\mathrm{N}$-terminally fused to the C-terminal end of mouse DHFRS protein and thus become more stable and less susceptible to proteolysis during expression. Ni-NTA-resin purified extracts from two hours induced and non-induced bacterial cultures containing the expression vector $\mathrm{PQE} 40-\mathrm{OC}$ and pQE40-pro-OC were analysed on SDS-PAGE. The same results as for the two pQE30 constructs were obtained. The positive control showed an expression product, whereas the two $p Q E 40$ constructs remained negative. After DNA sequence analysis of pQE40$O C$ and pQE40-pro-OC, it became clear that both constructs were ligated in the correct reading frame.

Theoretically, expression of the constructs was expected. Low expression levels are sometimes the result of poor plasmid maintenance in the cells. Ampicillin is a labile antibiotic, and is rapidly consumed in growing cultures. Stability of the plasmid maintenance can be improved by doubling the ampicillin concentration to $200 \mu \mathrm{g} / \mathrm{ml}$. Therefore, cells were grown in the presence of $200 \mu \mathrm{g} / \mathrm{ml}$ ampicillin until an ${ }^{\circ} D_{800 \mathrm{~nm}}$ of 0.7 was reached and then induced with IPTG. Ni ${ }^{2+}$-NTA-resin purified extracts from two hours induced and non-induced cultures were analysed on SDS-PAGE. In both pQE40OC and PQE40-pro-OC constructs expression products were obtained after 2 hours of 
induction. In case of the $6 \mathrm{His}-\mathrm{DHFR}-\mathrm{OC}$ the apparant molecular weight was $\sim 29 \mathrm{kDa}$ whereas the 6His-DHFR-pro-OC construct had an apparant molecular weight of approximately $31 \mathrm{kDa}$.

On Western blot using a primary antibody against $1-19$ osteocalcin, expression products could be detected. As a control 6 His-DHFR from the empty pQE 40 vector was negative for anti $1-19$ osteocalcin antibodies and positive when an anti $6 \mathrm{His}$ monoclonal antibody was used. 6His-DHFR could therefore be detected at $\sim 25 \mathrm{kDa}$. Both the osteocalcin expression products were also immunoreactive to anti-6His monoclonal antibody, and could be detected at the same molecular weight as when the anti 1-19 osteocalcin monoclonal antibody was used.

The amount of each expression product was determined with a protein analysis according to Sedmak et al. ${ }^{32}$. From $200 \mu / \mathrm{Ni}^{2^{2}}$-NTA-resin purified expression culture, derived from $1 \mathrm{ml}$ cell culture, $50 \mu \mathrm{l}$ was used for the measurement of total protein concentration. Subsequently the total protein concentration was corrected for the protein content of a induced negative control, which contained only the pREP4 vector. The amount of full length recombinant protein was estimated on the basis of the CBBgel (Figure 8) and expressed as percentage of total protein on gel. This percentage was used to calculate the concentration full length recombinant protein. 3 Hours expression of the pQE40 constructs in E. coli strain M15[pREP4] resulted in approximately $2 \mu \mathrm{g} / \mathrm{ml}$ of recombinant human osteocalcin. After 3 hours $1 \mathrm{ml}$ of bacterial suspension was taken from each expression culture, centrifuged and the bacterial pellet was resuspended in $250 \mu \mathrm{l}$ Triton/1x PBS. After sonication, the osteocalcin concentration in $50 \mu$ lof suspension was analyzed using the ELSA-OSTEO kit, according to the manufacturers protocol ${ }^{33}$. In the expression culture of M15[pREP4] pQE40 (negative control for osteocalcin) no detectable amount of osteocalcin could be measured. In expression cultures from three different pQE40-OC and pQE40-pro-OC clones, an osteocalcin concentration of approximately $40 \mathrm{ng} / \mathrm{ml}$ was detected. These low concentrations were in contrast with the intensity of the DHFR-OC and DHFR-pro-OC bands visible on CBB stained SDS-PAA gels and after Westerm blotting using anti 1-19 osteocalcin antibodies. A possible explanation for the low detection of the DHFR fusion 
proteins may be their poor recognition by the antibodies or the poor solubility of the fusion proteins.

The solubility of the DHFR-osteocalcin consructs turned out to be a major problem. Although expression levels were optimized and larger quantities of the osteocalcin fusion proteins could be produced and purified using Ni²+NTA-resin the proteins still were solubilized in $8 \mathrm{M}$ of urea. Dialysis of these protein solutions resulted in massive precipitations, and no proteins could be detected in the supernatant. With these results, 2 possibilities were considered; (i) to produce large amounts of purified insoluble DHFRosteocalcin fusion protein, yophilize it and subject the protein to CNBP-mediated cleavage, that might result in a soluble osteocalcin protein (either $\mathrm{OC}$ or pro-OC) or (ii) create a new fusion protein, in this case using MBP, with increased solubility and test this fusion protein directly or subject it to the same procedure as mentioned above using CNBr mediated cleavage. In the latter case only MBP-pro-OC which could function as a propeptide-containing substrate for carboxylase, was produced. A methionine residue was introduced at the C-terminus of $\mathrm{MBP}$ for cleavage with $\mathrm{CNBr}$. After construction of the MBP-pro-OC vector, it was introduced in a .JM 109 E. coli strain and multiplied. Isolation of the plasmid and subsequent DNA sequencing revealed that the pro-OC construct was in the proper reading frame. Expression cultures were subjected to SDS-PAGE and Western blotting and showed that indeed MBP-pro-OC was produced. Also it appeared that the protein was at least partly water-soluble, which facilitated its purification and fractionation. A drawback of the procedure was that both MBP alone and the MBP-pro-OC fusion protein had molecular weights of $\sim 51 \mathrm{kDa}$. This was due to the fact that at introduction of the CDNA coding for pro-OC in the PMALC vector, a sequence of similar length was removed. Hence, gel electrophoretic techniques could not reveal the ratio between unchanged MBP and the chimeric MBP. pro-OC in our preparations. Fractionation of the crude cell extract on amylose resin and subsequent analysis on SDS-PAGE showed a prominent band at $51 \mathrm{kDa}$ which was not recognized, however, by monoclonal antibodies against human osteocalcin (Western blot). This suggests that the expression of the chimeric fusion protein had been extremely low. 
Since neither DHFR-pro-OC nor MBP-pro-OC exhibited substrate activity for vitamin K-dependent carboxylase, we have tried to liberate the pro-OC moiety from the respective fusion proteins. At equal substrate concentrations $(100 \mathrm{ng} / \mathrm{ml} \approx 1.5 \mathrm{nM}$, as determined by ELISA) the ${ }^{14} \mathrm{CO}_{2}$ incorporation was $8.4 \mathrm{nmol} / \mathrm{hr}$ for pro-OC originating from MBP-pro-OC and $14.4 \mathrm{nmol} / \mathrm{hr}$ for pro-OC from DHFR-pro-OC. Because of the poor yield of both the pro-OC proteins, which resulted in substrate concentrations far below the expected $K_{m}(-1 \mu M)$, and the difficult purification of both preparations, it was decided to discontinue this line of substrate production, and to focus on substrates produced by organic synthesis. Polypeptides which had become available by then were: full length osteocalcin and descarboxy-osteocalcin, as well as a number of osteocalcin derived peptides.

\section{Discussion}

A plasmid expression vector has been constructed that directs synthesis in E. coll of human osteocalcin proteins containing an additional stretch of six histidine residues at its C-terminus. This enabled its single-step purification by chelate affinity chromatography. Initial expression experiments of human MGP and osteocalcin using the PQE30 expression vector and $E$. coli gave no detectable expression as analysed by SDS-PAGE. This was probably a result of the small size of both proteins. Stable expression in $E$. coli of small proteins is known to be difficult because they cannot fold correctly and are often subject to proteolytic degradation. Therefore, recombinant human osteocalcin was expressed as part of a DHFR fusion protein. The protein was fused to the C-terminus of mouse DHFR (6-His DHFR) in the vector pQE40, and expressed in $\mathrm{E}$. coli. Isolation of expression products through the $\mathrm{N}$-terminal 6 -His tag by using $\mathrm{Ni}^{2+}$-NTA-resin resulted in a product $>95 \%$ pure when analysed by SDSPAGE. Unfortunately this protein was highly insoluble.

Four main reasons for low expression are: presence of hydrophobic regions, toxic gene products, unstable proteins, or poor plasmid maintenance in the $E$. coli strain used. To prevent poor plasmid maintenance, the cultures were grown succesfully in the 
presence of $200 \mu \mathrm{g} / \mathrm{ml}$ of ampicillin. This leaves hydrophobic regions and toxicity of gene products as major causes for low expression. The toxicity of expressed proteins can be overcome by expressing proteins in freshly transformed cells. Normally the presence of very few transformants in comparison to the parent vector is an indication for toxicity of a gene product. The resulting transformants that do arise have often deletions and mutations. To overcome this problem transformants should be grown in media with high levels of antibiotics and $2 \%$ glucose. Since the amount of transformants obtained from both the parent vector and the construct vectors were closely similar, the possibility of toxic gene products was excluded. Growing the cell culture in media containing $200 \mu \mathrm{g} / \mathrm{ml}$ ampicillin turned out to be the only condition at which expression was established. Under these conditions poor plasmid maintenance was bypassed.

The presence of hydrophobic regions in recombinant proteins often have a toxic effect on the host cells, probably due to association of the protein with vital membrane systems. Examples of such hydrophobic regions are signal peptides and transmembrane sequences. Using the method developed by Kyte and Doolittle ${ }^{34}$ the hydrophobicity of both DHFR-OC and DHFR-pro-OC was determined, and it was found that none of the recombinant proteins had large hydrophobic stretches:

Identification of transmembrane regions was based on the method of Goldman, Engleman, and Steitz ${ }^{35}$. The values used are the sum of the hydrophobic and hydrophilic components of each amino acid. The hydrophobic components are derived from the free energy of transfer of water-oil for the amino acid side chains. The hydrophilic component is derived from the free energy for the insertion of charged groups into a membrane bi-layer, along with the free energy of the hydrogen bonding with water and the carbonyl groups of the protein background. The method is based on a sliding window of 20 to identify possible transmembrane regions. In the graphs thus obtained hydrophobicity is plotted as positive and hydrophilicity as negative. For both recombinant proteins no transmembrane regions were identified (data not shown). Thus, the low expression levels are not the result of hydrophobic regions such as transmembrane sequences. 
The detectable osteocalcin concentration in expression cultures of pQE40-OC, pQE40-pro-OC and MBP-pro-OC and the absence of osteocalcin in samples of pQE 40 is a good indication that the expressed protein is indeed recombinant osteocalcin. Only through protein-sequencing the exact identity of the protein can be established. Since the ELSA-OSTEO kit measures only $1-49$ human osteocalcin and human osteocalcin peptide $1-43$, the detectable concentrations of approximately $40 \mathrm{ng} / \mathrm{ml}$ should be interpreted with care. The expressed recombinant human osteocalcin is part of a fusion protein and/or contains the pro-peptide. Conformational differences between the recombinant and mature human protein can result in poor antibody recognition. Compared to the total protein concentration of $2 \mu \mathrm{g} / \mathrm{ml}$ full length construct, the detected $40 \mathrm{ng} / \mathrm{ml}$ osteocalcin is 50 fold lower.

\section{Conclusions}

Recombinant DNA technology as a tool to produce a desired protein is an elegant technique but certainly has its limitations. The yields depend on the type of proteins to be expressed. Furthermore, there is a great choice in systems to express recombinant proteins. Since the production of recombinant osteocalcin in our hands was hardly costeffective, the decision was made to obtain osteocalcin using a different technique.

As mentioned earlier in this chapter, there are other possibilities to obtain a specific protein, for instance by organic chemical synthesis. This field of research develops very rapidly, and what was impossible to synthesize a few years ago, is now routinely produced. Therefore we decided to have osteocalcin synthesized, both in its mature, carboxylated-as well as in its descarboxylated form. The synthetic peptide consisted of amino acid residues 1 to 49, which comprised of the entire mature sequence without the presence of a propeptide. One gram of both proteins was synthesized with a purity $>99 \%$. Both proteins were water soluble and could therefore be used for in vitro vitamin K-dependent carboxylation.

In the next paragraph, the possibilities of vitamin K-dependent in vitro carboxylation in various tissue types and the use of different substrates therein is discussed. 


\section{Paragraph 2.3}

VARIOUS IN VITRO VITAMIN K-DEPENDENT GAMMA-CARBOXYLATING TISSUES 


\section{Introduction}

Vitamin K-dependent carboxylase is present in a wide variety of mammalian cells and tissues, where it is involved in the production of different kinds of Gla-proteins. In some cases these Gla-proteins are unique products of one cell type; examples of this category are prothrombin and osteocalcin which are exclusively synthesized by liver (hepatocytes) and bone (osteoblasts), respectively. Other Gla-proteins, like protein S and matrix Gla-protein, are expressed at low levels in many different extrahepatic Iissues. Presently, there is a discrepancy between the tissue carboxylase content and the production of known Gla-proteins, such that it is to be expected that new Glaproteins will be discovered. One way of identifying these new proteins is to induce the accumulation of their intracellular precursors by treatment of experimental animals with vitamin K-antagonists. These precursor proteins may then be specifically labeled by in vitro carboxylation using ${ }^{14} \mathrm{CO}_{2}$, and subsequently purified and characterized using denaturing techniques. Reliable procedures for isolating and testing the vitamin Kdependent systems from various tissues is a first requirement for these investigations.

The vitamin $\mathrm{K}$-dependent carboxylase is a typical integral membrane protein, localized in the endoplasmic reticulum. After tissue homogenization, its activity can only be preserved by leaving the carboxylase within the microsomal membrane remnants, or by incorporating the enzyme into well-defined detergent micelles. Although there are no indications that carboxylases from different tissues are different gene products, accompanying proteins may affect the substrate specificity or affinity for vitamin $K$ of carboxylase. Besides carboxylases in various states of purification, research of this kind also requires the availability of potential substrates and substrate analogs, differing from each other in their primary structure and their affinity for carboxylase. Substrates for carboxylase may vary from simple, synthetic peptides (e.g. Phe-Leu-Glu-Glu-Leu, FLEEL) to polypeptides of more than 60 amino acid residues, which are generally produced by molecular biology techniques. The cofactors required are either vitamin $K$ hydroquinone (for assaying the carboxylase exclusively) or one of the oxidized forms (vitamin $K$ quinone or epoxide). In the latter case, the combined action of carboxylase 
and vitamin K reductase would be measured. In this paper the preparation procedures of enzymes, substrates and cofactors will be detailed.

\section{Preparation procedure for carboxylase from different tissues}

The best sources of vitamin K-dependent carboxylase are soft organ tissues, and the preparation procedures are very similar. Here we will describe the preparation of carboxylase from bovine liver, lung, kidney and testis, but the same procedure may be used for other tissues as well. Tissue homogenates may be frozen in liquid nitrogen and stored at $-80^{\circ} \mathrm{C}$ for several years without loss of carboxylase activity. For experiments in which a pretreatment of the animals precedes their use as organ donors, it may be practical to work with small animals like rats. In those cases in which the availability of the same (frozen) material over a long period is preferred, the cow is the experimental animal of choice. Also if large amounts of tissue are required (e.g. for purifications) the cheapest and most practical tissue donor is the cow.

\section{Washed microsomes}

Bovine liver, testis, kidney and lung are collected at the abbatoir, immediately after slaughter. The different tissues are cooled on ice and sliced in small pieces, following removal of the tougher parts like membranes, veins, and connective tissue. All subsequent steps are performed at $4^{\circ} \mathrm{C}$ unless stated otherwise. In a typical procedure, the sliced tissue is added to 2 volumes of buffer $\mathrm{A}(100 \mathrm{mM} \mathrm{NaCl}, 50 \mathrm{mM}$ Tris-HCl, $\mathrm{pH} 7.5)$ and minced in a blender. The mixed slurry is then homogenized in a Potter-Elvejhem tube (equipped with a teflon pestle) at 300 rpm with 2 strokes (up and down) of the pestle. At this stage the solution thus obtained may be either frozen. or used immediately for the preparation of microsomes (see below). In the latter case, $500 \mathrm{ml}$ of tissue homogenate are centrifuged for $45 \mathrm{~min}$ at $10,000 \mathrm{~g}$, after which the red supernatant fluid (post-mitochondrial fraction) is collected and centrifuged for 1 h at $105,000 \mathrm{~g}$. The supernatant fluid and a loose interface are discarded, and the pellets 
are transferred to the Potter tube, homogenized in $450 \mathrm{ml}$ of buffer $\mathrm{A}_{1}$ and centrifuged again for $1 \mathrm{~h}$ at $105,000 \mathrm{~g}$ (first washing step). Washing with buffer $\mathrm{A}$ is repeated until a colorless supernatant fluid is obtained (in total at least 3 washing cycles are required), and is followed by a washing step with buffer $\mathrm{B}\left(1 \mathrm{M} \mathrm{NaCl}_{8} 50 \mathrm{mM}\right.$ Tris-HCl, pH 7.5). Finally the pellet is resuspended in buffer $\mathrm{C}(0.5 \mathrm{M} \mathrm{NaCl}, 25 \mathrm{mM}$ Tris-HCl, $\mathrm{pH} 7.5)$, at a final protein concentration of approximately $40 \mathrm{mg} / \mathrm{ml}$. Washed microsomes thus obtained may be either subsampled and stored at $-80^{\circ} \mathrm{C}$ or used for further purification.

\section{Partly purified carboxylase}

During purification, carboxylase is increasingly sensitive to proteases. We therefore recommend the use of a protease inhibitor cocktail in all further steps described below. Unless mentioned otherwise, all buffers used in our purification procedure contain the following protease inhibitors: benzamidine $(1 \mathrm{mM})$, aprotinin $(0.3 \mu \mathrm{M})$, phenylmethylsulphonylfluoride (PMSF, $12 \mu \mathrm{M}$ ), dithiothreitol (DTT, 2 mM) and EDTA $(2 \mathrm{mM})$. Washed microsomes are supplemented with an equal amount of solubilization buffer ( $2 \%$ w/V CHAPS, $2 \mathrm{M} \mathrm{NaCl}$ ), stirred for $30 \mathrm{~min}$, and centrifuged for $2 \mathrm{~h}$ at 105,000 $x g$. The supernatant fluid (containing most of the carboxylase activity) is transferred into a pre-cooled flask to which ammonium sulphate is added with constant stirring to a final concentration of $55 \%$ saturation. The solution is kept at $4{ }^{\circ} \mathrm{C}$ for at least $30 \mathrm{~min}$ and subsequently centrifuged for $30 \mathrm{~min}$ at $20,000 \mathrm{x}$. The resulting "floating pellet" contains the major part of the carboxylase activity and is dissolved in buffer $\mathrm{C}$ to a final protein concentration of $18 \mathrm{mg} / \mathrm{ml}$. Aliquots of $1 \mathrm{ml}$ may be frozen in liquid nitrogen and stored at $-80{ }^{\circ} \mathrm{C}$ for several years. The preparation thus obtained is called "partly purified carboxylase" and was used in the experiments described below. Carboxylase has been identified in most soft tissues, except in brain and muscle, and the procedure described here can be used for nearly all tissues except those which are hard or tough (bone, cartillage, tendon and vessel wall). Partly purified carboxylase can also serve as the starting material for further purification of the enzyme. A protocol for the affinity purification of hepatic carboxylase to homogeneity will be described elsewhere in this 
volume. It should be noted, however, that for the affinily purification of extrahepatic carboxylases this protocol requires substantial adaptations; for instance the concentrations of salt and detergent concentrations must be optimized for each type of tissue.

\section{Substrates for carboxylase}

In vivo substrates for carboxylase invariably contain the so-called "pro-sequence", which serves as a recognition site for carboxylase. In most substrates the pro-sequence is located in the leader peptide, immediately preceeding the $\mathrm{NH}_{2}$-terminus in the mature protein 4 . Shortly before cellular excretion the pro-sequence is removed from the precursor protein by limited proteolytic degradation. Only in the case of matrix Glaprotein (MGP) does the pro-sequence form an integral part of the mature protein ${ }^{36}$. For in vitro carboxylation one may rely on endogenous precursor proteins which accumulate in the tissues during vitamin K-deficiency or warfarin-treatment of the donor animal ${ }^{37}$. In general this leads to a rapid carboxylation reaction which will come to an abrupt stop when the substrate is depleted. The carboxylation reaction continues for a prolonged period of time when reaction mixtures are supplemented with exogenous substrates. These substrates may be prepared by thermal decarboxylation of isolated Gla-proteins, by peptide synthesis or by the production of recombinant Gla-proteins in carboxylasedeficient systems.

\section{Decarboxylation of Gla-proteins}

In general decarboxylated Gla-proteins will not contain the pro-sequence, which is the main reason why they are poor substrates for carboxylase. Unfortunately the only exception (MGP) is highiy insoluble and difficult to isolate ${ }^{2}$. Therefore, this technique can only be recommended for one other protein, i.e. osteocalcin (also known as bone Gla-protein, BGP). As can be seen in many reviews the pro-sequences of all known Gla-proteins have a number of strictly conserved amino acid residues, e.g. Ala ${ }^{-10}$ and 
Phe ${ }^{-16}$, which implies that these residues are probably critical for substrate recognition by carboxylase. Osteocalcin forms an exception to this rule, because the $\mathrm{Ala}^{10}$ has been replaced by Gly. Substitution of either $\mathrm{Ala}^{-10}$ or Phe ${ }^{-18}$ by other amino acid residues strongly impaired substrate carboxylation of blood coagulation factors ${ }^{36}$. Hence it might be expected that the pro-sequence of osteocalcin has a relatively low affinity for carboxylase. This could be the reason why the osteocalcin molecule itself has developed in such a way that the mature sequence contributes significantly to the recognition by carboxylase. Whatever the reason may be, decarboxylated osteocalcin is a fairly good and easily prepared substrate for in vitro carboxylation ${ }^{39}$. Bovine tibia may be obtained from the abbatoir, cleaned, and defatted in acetone before they are ground in a bone mill. Further removal of traces of fat may be accomplished in a second acetone wash, after which the powder is extracted in three subsequent steps of $24 \mathrm{~h}$ each, with a solution containing $1 \mathrm{M} \mathrm{EDTA}, 0.2 \mathrm{M} \mathrm{KCl}, 10 \mathrm{mM}$ benzamidine, $5 \mathrm{mM} \mathrm{e-}$ aminocaproic acid, $1 \mathrm{mM}$ p-hydroxymercuribenzoate, $2 \mathrm{mg} / \mathrm{L}$ aprotinin, $\mathrm{pH}$ 8.0.In a typical preparation procedure one may use $500 \mathrm{~g}$ of bone powder and $3 \times 2$ litres of extraction buffer. After each extraction step the residue is removed by centrifugation $(5,000 \times g)$, and the supernatant is diluted 20 times with distilled water. Then, preswollen QAE-Sephadex slurry (in $20 \mathrm{mM}$ Tris- $\mathrm{HCl}, 0.1 \mathrm{M} \mathrm{NaCl}, \mathrm{pH} 8.0 ; 10 \mathrm{ml}$ per litre of diluted extract) is added followed by $2 \mathrm{~h}$ of stirring; the Sephadex is isolated by filtration over nylon cloth, and eluted with $1 \mathrm{M} \mathrm{NaCl}$. Osteocalcin is purified from the solution obtained by size exclusion chromatography on Sephadex $\mathrm{G}-75$, and by high performance liquid chromatography using a Mono- $Q$ column. Fractions may be tested using a commercial test kit with cross-reactivity for bovine osteocalcin (e.g. Incstar). For decarboxylation the peak fractions are pooled, dialysed against phosphate-buffered saline (0.14 M NaCl, 2.7 $\mathrm{mM} \mathrm{KCl}, 8.1 \mathrm{mM} \mathrm{Na} 2 \mathrm{HPO}_{4}, \mathrm{pH} 7.4$ ) and brought to $\mathrm{pH} 1$ with $0.1 \mathrm{M} \mathrm{HCl}$. This preparation is lyophilized to drymess, and subsequently heated to 105 ${ }^{\circ} \mathrm{C}$ overnight, under vacuum. Optimal results are obtained if during the entire heating period there is constant suction using a powerful vacuum pump. The preparation thus obtained is reconstituted with water to its original volume, and the $\mathrm{pH}$ is adjusted to 7.4 . The precise concentration of osteocalcin must be determined by at least two 
independent methods (e.g. protein measurement and a specific osteocalcin assay).

\section{Peptide synthesis}

It is surprising how little structural elements are required to permit the carboxylation of a peptide substrate. Of course, the predominant requirement is the presence of a glutamate residue. Glu derivatives like Boc-Glu methylester (Boc-Glu-Me) and short peptides like Phe-Leu-Glu-Glu-Leu (FLEEL) are commercially available (Bachem, Switzerland), and others (Boc-Glu-Glu-Val ${ }^{40}$ ) may be synthesized. These small substrates do not contain the pro-sequence, but since they can be added in high concentration, they allow for relatively high carboxylase activities. Different chain lengths of poly-Glu may also serve as a substrate for carboxylase ${ }^{41}$. A common characteristic of all these substrates is that their apparent $K_{m}\left(K_{m}\right.$ app $)$ is rather high (in the millimolar range). With the present technology it is possible also to synthesize substrates containing the pro-sequence of one of the coagulation factors, for instance the substrate known as proPT-28 containing the amino acid residues -18 through +10 of the human prothrombin precursor ${ }^{42}$.

\section{Molecular Biology}

Since prokaryotes do not contain the complicated machinery for posttranslational processing of proteins, expression of cDNAs from all Gla-proteins in prokaryotic systems will result in non-carboxylated proteins still containing the pro-sequence. This has been reported for osteocalcin ${ }^{43}$ as well as for coagulation factors and their Gladomains. In particular we draw attention to the peptide consisting of the pro-sequence and the first 41 residues of human coagulation factor IX. The preparation of this polypeptide (designated as prolX-59) and its crucial importance for the purification of carboxylase have first been described by Wu et al. ${ }^{10,11}$. These authors reported the construction of a cDNA coding for a chimeric protein composed of prolX-59, linked to a phage $T 7$ capsid protein ${ }^{44}$. The recombinant protein product accumulated in inclusion 
bodies, which were harvested and subjected to CNBr-mediated cleavage to liberate the recombinant prolX-59. After an anion exchange purification step, prolX-59 formed an excellent carboxylase substrate, all 12 glutamate residues of which may be carboxylated after prolonged incubation ${ }^{44}$. Even more important was the observation that prolX-59 - in contrast to proPT-28 - could be used as an affinity ligand for purifying carboxylase $^{45}$.

\section{Coenzymes for carboxylase}

Vitamin $\mathrm{K}$ hydroquinone $\left(\mathrm{KH}_{2}\right)$ is the active coenzyme for carboxylase, and it can be prepared by incubating $2.5 \mathrm{mM}$ of a detergent-solubilized vitamin $\mathrm{K}$ (e.g. Konakion ${ }^{\text {TMA }}$. or Aquamephyton ${ }^{\mathrm{TM}}$ ) in $150 \mathrm{mM}$ dithiothreitol, $\mathrm{pH} 8.5$, at $37^{\circ} \mathrm{C}$ overnight in a lightprotected tube. The resulting $\mathrm{KH}_{2}$ is colourless and gives the best results in $\mathrm{CO}_{2}$ incorporation studies. In non-purified systems, vitamin $K$ quinone $(K)$ and vitamin $K 2,3-$ epoxide (KO) may be used as coenzymes for carboxylase as well. In these cases, however, the coenzymes have to be reduced by the enzyme KO-reductase, which is present in washed microsomes from all tissues, and also in partly purified carboxylase from some sites (e.g. liver, testis). So if the carboxylase reaction is performed with either $\mathrm{K}$ or $\mathrm{KO}$ instead of $\mathrm{KH}_{2}$ the sequential activities of carboxylase and $\mathrm{KO}$-reductase will be tested. By comparing these data with those obtained for the $\mathrm{KH}_{2}$-initiated reaction, an impression may be obtained concerning the KO-reductase content of the preparation. $\mathrm{KO}$ is prepared by dissolving $20 \mathrm{mg}$ of phylloquinone in $5 \mathrm{ml}$ of isopropanol Thexane in a ratio of $2: 1(\mathrm{v} / \mathrm{v})$, to which $0.1 \mathrm{ml}$ of $0.5 \mathrm{M} \mathrm{NaOH}$ in $0.2 \mathrm{M} \mathrm{Na}_{2} \mathrm{CO}_{3}$ and 0.3 $\mathrm{ml} \mathrm{of} 30 \% \mathrm{H}_{2} \mathrm{O}_{2}$ are added ${ }^{46}$. After an overnight incubation in a light-protected tube at $37^{\circ} \mathrm{C}$ the mixture is supplemented with $3 \mathrm{ml}$ of water, vortex-mixed for $1 \mathrm{~min}$, and the hexane phase is collected. The latter is washed twice with $5 \mathrm{ml}$ of water and evaporated to dryness with gently heating under a constant stream of nitrogen. The residue is dissolved in ethanol to a concentration of $10 \mathrm{mg} / \mathrm{ml}$. 


\section{Optimal conditions for in vitro carboxylation of endogenous and exogenous} substrates

Endogemous substrates are protein precursors which have accumulated during in vivo treatment of the donor animals with vitamin K-antagonists (warfarin, brodifacoum). At least part of these precursor proteins remain complexed to carboxylase during the purification procedure, and may be carboxylated in vitro under the conditions described below. In general the supply of endogenous substrate is rapidly exhausted, and the addition of an exogenous substrate (e.g. the pentapeptide FLEEL) substantially increases the total amount of $\mathrm{CO}_{2}$ fixed. After the carboxylation reaction is completed, the (pro-containing) endogenous substrate can be separated from the short peptide substrate by trichloroacetic acid (TCA) precipitation (see below). An important difference between substrates which do and those which do not contain the prosequence is that the carboxylation of the latter ones is greatly enhanced (10-20 fold) by the presence of $1 \mathrm{M}\left(\mathrm{NH}_{4}\right)_{2} \mathrm{SO}_{4}$. The mechanism behind this stimulatory effect is not quilte clear, but kinetic analysis has shown that the high salt concentration affected the $V_{\text {max, }}$ and not the $K_{m}$ app 47 . No such an effect was observed for the carboxylation of endogenous precursor proteins, or for pro-containing substrates like proPT-28 and proll $X-59$. Another point to realise is that if radiolabeled bicarbonate is the only source of ${ }^{14} \mathrm{CO}_{2}$, the concentration of bicarbonate is the rate-limiting step in the carboxylation. The carboxylation rate will substantially increase by adding $5 \mathrm{mM}$ of non-labeled $\mathrm{NH}_{4} \mathrm{HCO}_{3}$, but obviously the amount of incorporated label will decrease. Carboxylase is not very stable at $37^{\circ} \mathrm{C}$, which is why most investigators work at $20^{\circ} \mathrm{C}$ or lower. Maximal substrate carboxylation may even be obtained in overnight incubations at 10 ${ }^{\circ} \mathrm{C}{ }^{48}$.

To allow the carboxylation reaction to proceed, the following ingredients should be pipetted in the order indicated to give $0.125 \mathrm{ml}$ reaction volumes of the following composition: $0.45 \mathrm{mg}$ of microsomal proteins, a suitable substrate (either $4 \mathrm{mM}$ of a substrate devoid of pro-peptide, or $20 \mu \mathrm{M}$ of a pro-containing one), $4 \mathrm{mM}$ dithiothreitol (DTT), $1 \mathrm{M}\left(\mathrm{NH}_{4}\right)_{2} \mathrm{SO}_{4}, 0.5 \mathrm{M} \mathrm{NaCl}, 25 \mathrm{mM}$ Tris- $\mathrm{HCl}$, and $5 \mu \mathrm{Ci}(185 \mathrm{kBq})$ of $\mathrm{NaH}^{14} \mathrm{CO}_{3}$. 
Reactions are initiated by the addition of $5 \mu(220 \mu \mathrm{M})$ of $\mathrm{KH}_{2}, \mathrm{~K}$, or KO. Incubation is performed for $30 \mathrm{~min}$ at $20^{\circ} \mathrm{C}$, and the reaction is stopped by adding $0.1 \mathrm{ml}$ of the reaction mixture to $0.8 \mathrm{ml}$ of $5 \%(w / v)$ trichloroacetic acid (TCA) in a giass vial, containing anti-bumping granules. The vials are boiled for a short time ( $2 \mathrm{~min}$ ) on a hot plate to remove the last traces of unbound ${ }^{14} \mathrm{CO}_{2}$, after which scintillation liquid is added for radiolabel counting.

\section{Optimal conditions for measuring KO-reductase in microsomal fractions}

During the carboxylation reaction, $\mathrm{KH}_{2}$ is oxidized into $\mathrm{KO}$, which may be recycled via the action of the enzyme KO-reductase. Several procedures for the assessment of KOreductase have been described, the data shown below were produced using the method described by Thijssen ${ }^{49}$ "Reaction mixtures $(0.25 \mathrm{ml})$ contained $0.9 \mathrm{mg}$ of microsomal proteins, $1 \mathrm{M}\left(\mathrm{NH}_{4}\right)_{2} \mathrm{SO}_{4}, 0.5 \mathrm{M} \mathrm{NaCl}, 4 \mathrm{mM}$ dithiothreitol (DTT) and $25 \mathrm{mM}$ Tris- $\mathrm{HCl}, \mathrm{pH} 7.5$. After a pre-incubation of $2 \mathrm{~min}$ at $20^{\circ} \mathrm{C}$, reactions were started by adding $10 \mu \mathrm{l}$ of $220 \mu \mathrm{M} \mathrm{KO}$ in ethanol. After incubation periods of $0,5,10$ and $20 \mathrm{~min}$, $50 \mu \mathrm{l}$ aliquots were taken and extracted with $1 \mathrm{ml}$ isopropanol / hexane $(2: 1, \mathrm{v} / \mathrm{v})$ containing $5 \mu \mathrm{g} D-\alpha$-tocopherol as an internal standard. After the addition of $1 \mathrm{ml}$ of water, the mixtures were vortexed and $0.2 \mathrm{ml}$ of the hexane phase was taken and evaporated to dryness under a gentle stream of $\mathrm{N}_{2}$ at room temperature. The residue was dissolved in $50 \mu$ is isopropanol of which $20 \mu \mathrm{l}$ was used for HPLC analysis ${ }^{15}$. The enzyme activity was deduced from the initial reaction rate during the first 10 minutes of incubation.

\section{Comparison of enzymatic activities of hepatic and extrahepatic carboxylases}

The enzymes of the vitamin $K$ cycle obtained from different tissues may be compared by a) measuring the carboxylase and KO-reductase per mg of protein, and b) by assessing their respective kinetic constants. In these measurements, it is important that substrates and cofactors are present in excess and that the rate of product formation 
is assessed under linear reaction rate conditions. Carboxylase activity is assessed by initiating the carboxylation reaction with $\mathrm{KH}_{2}$. A test for the simultaneous activities of carboxylase and $\mathrm{KO}$-reductase is performed by initiating the carboxylase reaction with $\mathrm{KO}$. If $\mathrm{KO}$-stimulated carboxylase is less than $25 \%$ of the $\mathrm{KH}_{2}$-driven reaction, this is indicative of a relative KO-reductase deficiency of the preparation. This can be assessed in a more direct way by measuring the conversion of vitamin K-epoxide into the corresponding quinone. In table 1 we have summarized these three enzymatic activities for the four partly purified carboxylase preparations presented in this paper. It is clear that partly purified carboxylase was obtained from all four tissues and that the activities of the extra-hepatic preparations ranged from $23-84 \%$ of that obtained from the liver. KO-reductase was present in washed microsomes from all tissues but, on fractionation, the enzyme activity was lost in the preparations from kidney and lung.

\section{Table 1}

Partly Purified Carboxylase From Different Origins: Comparison of Tissue Content ${ }^{a}$

\begin{tabular}{lccc}
\hline Origin of carboxylase & $\begin{array}{c}\mathrm{KH}_{2} \text { carboxylase } \\
\left(\mathrm{pmol} \mathrm{CO}_{2} \text { fixed }\right)\end{array}$ & $\begin{array}{c}\mathrm{KO} \text { carboxylase } \\
\text { (pmol } \mathrm{CO}_{2} \text { fixed) }\end{array}$ & $\begin{array}{l}\text { Ko reductase } \\
\text { (pmol K formed) }\end{array}$ \\
\hline Liver & 0.93 & 0.24 & 69 \\
Testis & 0.78 & 0.19 & 496 \\
Kidney & 0.36 & 0 & 0 \\
Lung & 0.22 & 0 & 0 \\
\hline
\end{tabular}

Carboxylase actwlyy is expressed as picomoles $\mathrm{CO}_{2}$ incorporated per milligram of microsomal protein and par mintite of incubation at $20^{\text {w }} \mathrm{C}$, using the pentapeptide FLEEL as a substrate. $\mathrm{KH}_{2}$ carboxylase means that the reaction was initiated with vitamin K hydroquinone. $K O$ carboxylase stands for the carboxylation reaction initiated with vitamin $K$ apoxide. KO reductase is expressed as picomoles vitamin $k$ quinone formed per milligum of microsomal protein and per minute of incubation at $20^{\circ} \mathrm{C}$, using witamin $\mathrm{K}$ epoxide as a substrete.

This loss was due to inactivation (probably because of the high detergent concentration) rather than to separation in a different fraction. Partly purified carboxylase from liver and testis contained high levels of $\mathrm{KO}$-reductase, and it appears that the testis especially is the tissue of choice for the purification of KO-reductase. 
Another striking point is that there is no apparent stoichiometry between carboxylase and reductase: in terms of picomoles of product formed, the enzymatic activity of reductase exceeds that of carboxylase by 75 (liver) to 635 (testis) fold. The reason for this large excess of reductase is not known, but obviously it will result in a rapid reduction of any $\mathrm{KO}$ formed.

Differerit carboxylase preparations can also be compared by measuring their kinetic constants using various substrates. In table 2 we show the results for 6 different substrates tested in the four partly purified carboxylase preparations.

\section{Table 2}

Partly Purified Carboxylases From Different Origins: Comparison of Substrate Specificity ${ }^{a}$

\begin{tabular}{|c|c|c|c|c|c|c|c|c|}
\hline \multirow[b]{3}{*}{ Substrate used } & \multicolumn{8}{|c|}{ Origin of carboxyllase } \\
\hline & \multicolumn{2}{|c|}{ Luver } & \multicolumn{2}{|c|}{ Testis } & \multicolumn{2}{|c|}{ Kidney } & \multicolumn{2}{|l|}{ Lung } \\
\hline & $\mathrm{K}_{\mathrm{m}} \operatorname{sep}$ & $V_{\text {maxix }}$ & $K_{\text {ing }}$ & $V_{\text {matx }}$ & $\mathrm{K}_{\mathrm{n}} \mathrm{app}$ & $V_{\text {mingex }}$ & $K_{\mathrm{rry}}$ & $V_{\text {max }}$ \\
\hline FEELL & $2.2 \mathrm{mM}$ & 1.4 & $2.7 \mathrm{mM}$ & 1.0 & $2.11 \mathrm{mM}$ & 0.6 & $2.2 \mathrm{mM}$ & 0.4 \\
\hline Bac-EEV & $1.6 \mathrm{mM}$ & 1.1 & H. 3 mM & 0.9 & $1.2 \mathrm{mM}$ & 0.5 & $1.3 \mathrm{mM}$ & 0.2 \\
\hline Bac-Glu-Me & $2.4 \mathrm{mM}$ & 1.0 & $2.5 \mathrm{mM}$ & 0.8 & $2.7 \mathrm{mM}$ & 0.4 & $2.7 \mathrm{mM}$ & 0.2 \\
\hline D-Osteocralcin & $8.2 \mu \mathrm{M}$ & 0.19 & $6.8 \mathrm{H}$ & 0.11 & $7.2 \mu$ & 0.08 & a. $3 \mathrm{~m}$ & 0.04 \\
\hline PIOPT(GHu) & $4.11 \mathrm{MM}$ & 0.24 & 4.9 jilly & 0.12 & $3.5 \mu$ H & 0.06 & $27 \omega$ & 0.05 \\
\hline PIOPT-28 & $2.1 H M$ & 0.24 & $3.5 \| \mathrm{H} N$ & 0.14 & 2.7 $\mu$ H & $0.0 \%$ & $3.0 \mu M$ & 0.03 \\
\hline Prol $x-59$ & $0.8 \mathrm{kH}$ & 0.25 & 1.t. & 0.13 & $1.2 \mu \mathrm{M}$ & 0.08 & $1.5 \mathrm{H}$ & 0.03 \\
\hline $\begin{array}{l}\text { Kapp for the fi } \\
\text { is expressed } \\
28 \text { stands for } \\
\text { sequence } 18 \\
\text { cartooxy-lermi }\end{array}$ & $\begin{array}{l}\text { tes is a } \\
\text { orporate } \\
\text { precurs } \\
\text { Glu } \|_{10} \text { st }\end{array}$ & $\begin{array}{l}\text { xpress } \\
\text { d per } n \\
\text { or sea } \\
\text { ands f }\end{array}$ & $\begin{array}{l}\text { n millim } \\
\text { te and } p \\
\text { ce }-18 \text { to } \\
\text { e prothe }\end{array}$ & $\begin{array}{l}\text { olar }{ }^{\prime} \text { fo } \\
\text { per mill } \\
\text { o }+10 " \\
\text { fombin }\end{array}$ & $\begin{array}{l}\text { last thre } \\
\text { m of micic } \\
\times-59 \text { sta } \\
\text { xeptide w }\end{array}$ & $\begin{array}{l}\text { Bes sulo } \\
\text { rosiom } \\
\text { ands fo } \\
\text { with } 10\end{array}$ & 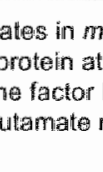 & 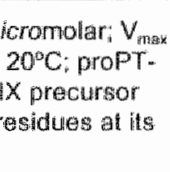 \\
\hline
\end{tabular}

Peptide substrates lacking the pro-sequence have $K_{m}{ }^{\text {app }}$ values in the millimolar range, except for decarboxylated osteocalcin the mature sequence of which seems to 
contribute substantially to the enzyme-substrate recognition. The reason for this unique property is presently unknown. $K_{m}$ app values for pro-containing substrates are at least three orders of magnitude lower than those for the short peptides. The fact that there is very little difference between a pro-sequence connected to a sequence derived from a clotting factor, and that linked to poly-L-glutamate demonstrates that the prosequences in the clatting factor precursors are the major (if not the only) structural requirement for enzyme-substrate interaction. Strikingly, there is a large difference between the carboxylation of peptide substrates in the presence of non-covalently bound propeptide, and the carboxylation of polypeptides containing both the prosequence as well as the carboxylatable glutamate residues. As was reported by Ulich et al. ${ }^{42}$, the $K_{m}$ app for small substrates like FLEEL and PT/1-10 (descarboxyprothrombin residues $1-10$ ) decreased by a factor of three with the addition of non-bound propeptide, but it was at least a thousand times lower if the pro-peptide was covalently attached. Similarly, pro-containing substrates decreased the $K_{m}{ }^{a p p}$ of carboxylase for its cofactor $\mathrm{KH}_{2}$ about 20-fold, whereas the combination of pro-peptide + peptide substrate did not ${ }^{50}$. Thus, the covalent attachment of the pro-peptide and the substrate glutamate residues is a critical requirement for efficient carboxylation of the substrate.

The fact that the kinetic characieristics of carboxylases from various tissues are very similar is consistent with the idea that all are products of the same gene. It is to be expected, therefore, that the various extrahepatic Gla-proteins rather than the extrahepatic carboxylases may be a subject of interest in forthcoming years. Warfarin treatment of animals, followed by endogenous substrate labeling in the in vitro carboxylase reaction is a promising technique to recognize these proteins during their purification and characterization, even if they would have lost all functional activity.

\section{Conclusions}

The methods to obtain carboxylase from hepatic and extra-hepatic tissue microsomes described in this paragraph are basic but still valid. Several authors have already described the purification of the enzyme from bovine liver and mammalian cell lines ${ }^{51-53}$. 
Stafford et al. reported a method to purify endogenous substrate-free human $y$-glutamyl carboxylase expressed in an insect cell line (D.W. Stafford, unpublished results), thus the use of washed microsomes in vitamin $\mathrm{K}$ research may be questioned. However, from data obtained with either carboxylase from washed microsomes, purified bovine carboxylase or purified human carboxylase it is evident that the results are similar, if the $K_{m}$ values of the substrates used are compared. The $V_{\max }$ values may vary for a certain substrate if different preparations of carboxylase are used, depending on the enzyme concentration of the preparation, especially if washed microsomes are used as the source for carboxylase. To obtain accurate data on substrate properties for carboxylase, the propeptide- and endogenous substrate free human carboxylase from insect cells is the best choice. However, to obtain this form of carboxylase, sophisticated molecular biology techniques have to be available in combination with facilities for eukaryotic cell cultures. Moreover, the purification of the enzyme is laborious and time consuming. Therefore, washed microsomes are still a usefull source for carboxylase data on enzyme- and substrate properties. The method is simple, does not require specific techniques and can be performed in one day. Moreover it should be kept in mind that the purified carboxylase preparations possess neither vitamin $\mathrm{KO}$ nor vitamin K reductase activity. Since the reductase enzyme has not yet been purified, the washed microsomal system forms the only possibility to investigate the combined function of carboxylase and reductase.

\section{Acknowledgements}

Henri H.M. Spronk, M.Sc. and Leon Schürgers, B.Sc. are gratefully acknowledged for their practical help and technical advise regarding molecular biology and protein purification.

The work in the author's laboratory described in this chapter was supported by grant 93.003 from the Netherlands Thrombosis Foundation. 


\section{References}

1. Wauschka, P. V., Lian, 4, B., Cole, D. E. Q Gundberg, C. M. Osteocalcin and matrix Gila protein: witamin K-dependant proteins in bone. Physiol Rev 69, 990-1047 (1989).

2. Price. P. A. Role of vitumin-K-dependent proteins iri bone metabolism. Annu Rev Nutr $8,565-83$ (1988)

3. Verneer, C. Gamma-carboxyglutamatemontaining proteins and the vitamin K-dependant carboxylase. Brocham $266,625-636(1990)$

4. Furie, B. \& Fune, B. C. Molecular basis af vitamin Kadependent gammawcarboxylaton. Blood 75. 1753$1762(1990)$.

5. Brown. \. P. et al. Serum bone Gla-protein: a specific marker for bone formation in postmenopausal osteoporosis. Lancet 1, 1091-1093 (1984).

6. Ismail, F. al. Senm bona gla protein (BGP) and other markers of bone mineral metabolism in posthenopausal osteoporosis [published erratum appeared in Calcif Tissue int $1987,40(2): 147)$. Colchf Tissue Int 39, $230-233$ (1986).

7. Price, P. A.,Parthemore, J. G. \& Deftos, L. J. New biochemical marker for bone metabolism.

Measurement by radioimmunoassay of bone GLA protein in the plasma of nomal subjects and pattents with bone disease. I CWn Invest 60, 878 -883 (1980).

B. Powwer, M. 4. \& Fottrell, P. F. Osteocalcin; diagnostic methods ancl clinical applications. Crit Rev Chin Lab Sol $28,287-335(1991)$.

9. Diaz Diego, E. M. Guerrero, R. \& de la Piedra, C. Six osteocalcin assays compared. Chin Chem 40 , $2071-2077(4994)$.

10. Knapen "M. H. Eisenwiener, H. G. \& Verneer, C. Osteocalcin detection in aging serum and whole blood: stability of different osteocalcin fractions. Cin Chim Acta 256, 151-64 (1996).

11. Hart, 4. P. el al. Circulating vitamin K1 lewels in fractured neck of femur [letter], Lancot 2, 283 (1984).

12. Hari, J. P. et al. Ellectrochemical detection of depressed circulating levels af vitamin K1 in osteoporosis. I Gin Endocrinol Metab 60, 1268-1269) (1985).

13. Bitensky, L. et al. Circulating witamin K levels in patients with fractures. J Bone Joinf Surg [Br] 70, 663$664(1989)$.

14. Hodgos, S. J., Akesson, K., Vargnaud, P., Obrant, K. \& Delmas, P. D. Circulating levels of vitamins K1 and K2 decreased in widerly women with hip fracture. J Bone Miner Res 8. 1241-1245 (1993).

15. Jie, K. G. Bots, M. L. Vemeer, C. Witteman, J. C. Grobbee, D. E. Vitamin K status and bone mass in women with and without aortic atherasclerosis: a population-besed study. Calcir Tissue int 59,352 $356(1996)$.

16. Knapen, $M$. H. Hamlilyak, K. \& Wemeer, $C$. The effect of vitamin $K$ supplementation on circulating osteocalcin (bone Gla protein) and urinary calchum exction. Anw Interm Med 111, 1001\%1005 (1989)

17. Knapen, M. H., wie, K. S., Hamulyak, K. \& Vermeet, C. Vitamin K-induced changes in markers for osteoblast activity and utinary calcium loss. Cakcif Tissue int 53, 81-85 (1993).

18. Szulc. P. et al. Serum undercarboxylated osteocalcin correlates whith hip bone mineral density in widenty

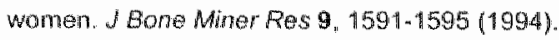

19. Szulc, P. Chapuy, M. C. Meunier, P. J. \& Delmas, P. D. Sentm undercarboxylated osteocalcin is a 
marker of the risk of hip fracture in elderly women. J Chin invest $94,1769-1774(1993)$.

20. Chu, K. Wu, S. M., Stanley, T., Stafford, D. W. \& High, K. A. A mutation hn the propieptive of Factor IX leadis to warfarin sensitivity by a nowel mechanism. A Chin Imvest 98, 1619-1625 (1996).

21. Caims, J. R. \& Price, P. A. Direct demonstration that the witamin K-dependent bone Gla protein is incompletely gamma-carboxylated in humams. J Bone Miner Res 9, 1989-9197 (1994).

22. Nakao, M., Nistriuchi, Y., Nakata, M. Kimura, T. \& Sakakibara, S. Synthesis of human osteociallins: gamma-carboxyglutanhic acid at position 17 is essential for a calciumadependent conformationet transition. Pept Res $7,171-174$ (1994).

23. Chang, G. T, et al. Expression and characterization of recombinant human protein $S$ in heterologous cells--studies of the interaction of amino acid residues leu-608 to glu-612 with human $\mathrm{C} 4 \mathrm{~b}$ protein. Thromb Haemost 67, $526-532(1992)$.

24. Christiansen, W. T. \& Castellino, F. J. Properties of recombinant chmeric human proteily $C$ and activated protein $C$ containing the gamma-carboxyglutamic acid and trailing hellcal stack domains of protiain C replaced by those of human coagulation factor $\| X$. Biochemistry $33,5901-11(1994)$.

25. (Campro Scientitic, Veenendaal, The Nethertands, 1991).

26. Maniatis, T. Fritsch, E. F. \& Sambrook, J. Molecular Cloning. A laboralory manual (Cold Spring Harbor Laboratony, Cold Spring Habor "NY., 1982).

27. ABI PRISIV1310 Genetic Analyzer user's manual (Perkin Emer, Foster City, CA, 1995 ).

28. Perkin Elmer Protogol P/N 402078 revision A, August 1995, Foster City, CA. (1995).

29. Laemmli, U. K. Cleavage of structural proteins during the assembly of the head of bacteriophage T4. Native 227, $680-685(1970)$.

30. Towbin, H., Staehelin, T.\& Gordon, J. Electrophoretic transfer of proteins from polyacrylamide gels to nitrocellulose sheets: procedure and some applications. Proc Nall Acad Sci USA 76, 4350-4354 (1979).

31. The QIA expressionist, 2nd Edition (QIAGEN Inc, Chatsworth, CA, 1992).

32. Sedmak, J. J. \& Grossberg. S. E. A rapid, sensitive "and versatille assay for protein using Coomassie brilliant blue G250. Ana/ Biochem 79, 544-552 (1977).

33. ELSA-OSTEO User"s manual (CIS Bio Intenational, France).

34. Kyte, J. \& Doolittle, R.F. A simple method for displaying the hydropathic character of a protein. $J$ Mol Biol 157, 105-132(1982).

35. Engelman, D. M., Stertz, T. A. \& Goldman, A. Identifying nonpolar transbillayer hellces in amino acid sequences of membrane proteins. Ainn Rev Blophys Blophys Chem 15, 321-353 (1986).

36. Price, P. A. Fraser, J. D. \& Metz Virca, G. Molecular cloning of matrix Gla protein: irmplicalions for substrate necognition by the whtamin K-dependent gamma-carboxylase. ProG NaU Acad SCI USA O4, $8335-8339(1987)$.

37. Soute, B. A, Ulrich, M. M. \& Vermeer, C. Vitamin K-dependent carboxylase: increased afficiency of the carboxylation feaction. Thromb Haemos! 57; 77-81, (1987).

38. Worgensen, M. J. et al. Recognition site directing vitamin K-dependent gamma-carboxylation resides an the propeptide of faction IX. Cell 48, 185-191 (1987).

39. Vemeer, C., Soute, B. A., Hendrix, H. \& de Boer van den Berg, M. A. Decarboxylated loone Gla-protein as a substrate for hepatic vitamin Kudependent carboxylase. FEBS Leff 165, 16-20 (1984). 
40. Acher, F. 2. Azerad, R. Synthesis of dastereoisomenic peptides incorporatho cyclogitumic acids. Substrate specificity of wtamin Kudependent carboxylation. Int I Pept Protein Res 37, 210-219 (1991).

41. Soute, B. A., Bude, R. \& Vermeer, C. Vitamin K-dependent carboxylation of poly-L-glutamate. Biochim Biophys Acto 1073, 434436 (1991).

42. Ulrich, M. M. Furie, B., Jacobs, M. R. Vermeer, C. Furie, B. C. Vitamin K-dependent canboxylation. A Synthetic peptide based upon the gamma-carboxylation recognition site sequence of the prothombin propeptide is alf active substratwe for the carboxylase in vitro. J Biol Chem 263, 9697-9702 (1988).

43. Benton, M. E. Price, P. A. \& Suttie, J. M. Multi-site-specificity of the vitamin K-dependent carboxylase: in vitro carboxylation of des-gamrna-carboxylated bone Gla protein and Des-gamma-carboxylated pro bone Gla protein. Brochemistry 34, 9541.9551 (1995).

44. Wu, S. M., Solte, B. A., Vermeer, C. Staford, D. W. In vitro gamma-carboxylation of a 59 -residue recombinant peptide including the propeptide and the giamma-carboxyglutamic acid domain of coagulation factor IX. Effect of mutations noar the propeptide cleawage site. J Biol Chem 265, 13124 $13129(1990)$.

45. Wu, S. M. Morris, D. P.\& Stafford, D. W. Idertification and purification to near homogeneitly of the whtamin K-dependent carboxylase. Proc Naul Acad Sci USA 88, 2236-2240 (1991).

46. Fieser, L. F., Tishler, M. \& Sampson, W. L. J Biol Chem 137, 659 (1944).

47. Soute, B. A. Acher, F., Azerad, R. \& Vermeer, C. Vilamin K-dependent carboxylase: effect of ammonium sulfate on substrate carboxylation and on inhibition by stereospecific substrate analogs. Bhochim Biophys Acto 1034, 11-16 (1990).

48. Soute, B. A., Bude, R.. Butenhuis, H. \& Vermeer, C. Vitamin K-dependent carboxylase: minimized escape of $\mathrm{CO}_{2}$ from solution may prolong linearity of the reaction rate. Anal Brochem $182,207-211$ $(1989)$

49. Thilssen, H. H, Janssen, C. A. \& Dritti-Relinders, M. the The effect of S-warfarin administration on witamin K, 2,3 -epoxide reductase activity in liver, kicney and tesis of the rat. Biochem Phamacol 35. $3277-3282(1986)$.

50. Soute, B. A. et al Congenital deficiency of all vilamin K-dependent blood coagulation factors due to a defective vitamiri K-dependent carboxylase in Devon Rex cats. Thromb Haemost 68, 521-525 (1992).

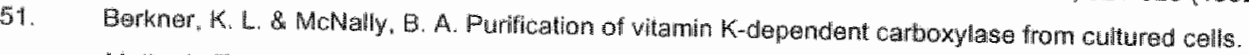
Methods Enzymol 282, 313-333 (1997).

52. Furie, B.C. al. Purfication of native bovine carboxylase and expression and purification of tecombinant bovine carboxylase. Method's Enzymol 282, 333-346 (1997).

53. Wu, S. MA. Mutucumarana, V. P. S Stafford, D. W. Purification of gamma-glutamyl carboxylase from bovine liver. Methods Enzymol 282, 346-357 (1997). 


\section{Chapter 3}

\section{THE ROLE OF THE PROPEPTIDE AND GAMMA-GLUTAMIC ACID DOMAIN OF FACTOR IX FOR IN VITRO CARBOXYLATION BY THE VITAMIN K-DEPENDENT CARBOXYLASE}

Thomas B. Stanley ${ }^{\ddagger}$, Sheue-Mei Wu ${ }^{\ddagger}$, Roger J.T.J. Houben $\$$, Vasantha P. Mutucumarana ${ }^{\ddagger}$, and Darrel W. Stafford ${ }^{\ddagger}$

Department of Biology, Center for Thrombosis and Hemostasis, University of North Carolina at: Chapel Hill, Chapel Hill, North Carolina 27599-3280, U.S.A. and the "Department of Biochemistry and Cardiovascullar Research institute, Maastricht Universily, Maastricht, The Netherlands. 


\section{Abstract}

The vitamin K-dependent $y$-glutamyl carboxylase catalyzes the processive carboxylation of specific glutamates in a number of proteins related to blood coagulation and bone. To address the independent importance of the propeptide, $\gamma$-carboxyglutamic acid (gla) domain and elements beyond the gla-domain of factor IX in vitamin K-dependent carboxylation, we have examined the kinetics of carboxylation of peptides containing: 1) propeptide and gla-domain, 2) the gla-domain alone, 3) uncarboxylated osteocalcin, 4) propeptide followed by the entire uncarboxylated factor $\mid X$ molecule, and 5) the factor IX propeptide followed by a non-gla-domain sequence. Our studies indicate that peptides with a covalently linked propeptide have $K_{m}$ values similar to the physiological substrate of the carboxylase. In contrast, the gla-domain of factor IX has a 2230 - fold higher $K_{m}$ for the carboxylase than the corresponding peptide with a covalently linked propeptide. This contrasts with osteocalcin, another vitamin K-dependent protein, which appears not to require a covalently linked propeptide for high affinity binding to the carboxylase. Analysis of the carboxylation products of a propeptide/non-gla-domain substrate indicate that it is carboxylated multiple times in a processive manner. These studies show that the perceived binding affinity of the carboxylase substrate and processivity is conferred by the propeptide without requiring the conserved gla-domain sequences and that factor IX and osteocalcin may have distinct mechanisms of interacting with the carboxylase. 


\section{Introduction}

The vitamin K-dependent $y$-glutamyl carboxylase is an integral membrane protein that is found in the rough endoplasmic reticulum and has been purified from bovine liver", cloned and sequenced ${ }^{2,3}$. In addition to its carboxylase activity, the purified vitamin $K$-dependent carboxylase also possesses the vitamin $K$ epoxidase activity ${ }^{4}$. The vitamin $K$-dependent carboxylase catalyzes the post-translational modification of specific glutamic acid residues to $\mathrm{Y}$-carboxyglutamic acid (Gla) in a number of proteins essential for blood clotting as well as for the bone-related proteins: osteocalcin and matrix Gla protein (MGP) ${ }^{5-8}$. Vitamin K-dependent proteins may be even more prevalent than previously thought as evidenced by the discovery of growth-arrest protein Gas- 6 and the very recent identification of two putative vitamin K-dependent membrane proteins PRGP1 and PRGP2 ${ }^{10}$.

The amino-terminal domain of the mature vitamin K-dependent blood proteins where multiple glutamic acid residues are converted to $y$-carboxyglutamic acid is referred to as the gla-domain. The gla-domains of the known vitamin K-dependent blood proteins share extensive sequence identity. In addition, all of the known vitamin K-dependent proteins contain a highly conserved propeptide region that is proteolytically removed to form the mature protein (except for MGP where the propeptide-like sequence is found within the mature form of the protein) ${ }^{11}$. Expression of vitamin K-dependent proteins in mammalian cell culture demonstrates that deletion of the propeptide region from factor $\mathrm{IX}^{12}$ or protein $\mathrm{C}^{13}$ abolishes carboxylation, while specific amino acid substitutions within the eighteen amino acid propeptide sequence affect carboxylation ${ }^{12,14,15}$. Furthermore, naturally occurring mutations in the factor $I X$ propeptide region have been found in warfarin sensitive hemophilia $B$ patients ${ }^{16,17}$. Synthetic peptides spanning the propeptide and first 40 residues of the gla-domain of factor IX or prothrombin have an apparent affinity for the carboxylase that is three orders of magnitude lower than the small glutamate substrate FLEEL 18.19 "These studies indicate that the propeptide plays an essential role in the carboxylase's ability to recognize its substrate. 
There is also ample evidence that the interaction of the carboxylase with the propeptide activates the enzyme. Evidence for propeptide activation of the enzyme is seen in studies which suggest that the propeptide lowers the apparent $K_{m}$ for glutamate ${ }_{20}$ "lowers the apparent $K_{\mathrm{m}}$ for vitamin $K^{21}$, increases formation of the carbanion intermediate ${ }^{22}$ and activates the epoxidase activity of the carboxylase ${ }^{23}$. Therefore the propeptide has a dual role as a primary recognition element for the carboxylase as well as an allosteric activator of enzyme activity.

Most studies of the carboxyllase have utillized small glutamic acid containing substrates ${ }_{n}$ such as the pentapeptide FLEEL or peptides containing the propeptide and two potential carboxylation sites. Although these studies have provided important information about the carboxylase, elucidation of carboxylase kinetics and mechanism requires the use of peptides that are multiply carboxylated and that more closely resemble the native substrates of the enzyme. Previous work from our laboratory has shown that the FIXproGLA41 peptide, which contains the factor FIX propeptide followed by the first 41 amino acids of the gla-domain of factor IX, possesses a number of qualities expected of in vivo substrates of the vitamin K-dependent carboxylase. Specifically this peptide contains all twelve glutamates normally carboxylated in factor IX, has a physiologically reasonable affinity for the carboxylase, can be fully carboxylated ${ }^{24}$, and is processively carboxylated ${ }^{25}$. Therefore, the propeptide and the gla-domain alone are sufficient to direct processive carboxylation. In contrast to numerous studies which indicate that an amino-terminal propeptide extension is important for recognition by the carboxylase, studies with thermally decarboxylated osteocalcin indicate that a covalently attached propeptide is not necessary for binding of the carboxylase ${ }^{26-28}$. Osteocalcin is a 49 amino acid vitamin K-dependent protein that contains three gla residues and is expressed with an eighteen amino acid propeptide extension analogous to the blood vitamin K-dependent proteins. The mature asteocalcin shares little sequence identity with the gla-domains of the blood vitamin K-dependent proteins, except for a conserved sequence identified by Price " Therefore, for osteocalcin, essential elements other than the propeptide appear to be involved in substrate recognition. 
In this paper the relative contribution of the propeptide and gla-domain of factor IX to vitamin $K$-dependent carboxylation has been examined by in vitro kinetic studies with purified components. These sudies show that the perceived binding affinity of the carboxylase substrate and processivity is conferred by the propeptide without requiring the conserved gla-domain sequences and that factor $I X$ and osteocalcin may have distinct mechanisms of interacting with the carboxylase. 


\section{Materials and Methods}

Reagents

All chemicals were reagent grade. Vitamin $K_{\|}$(phylloquinone) was from Abbott Laboratories, FLEEL was purchased from Bachem. Phosphatidylcholine, Type X-E from dried egg yolk is from Sigma. $\mathrm{NaH}^{14} \mathrm{CO}_{3}$ with specific activity of $56.4 \mathrm{mCi}$ mmol was from ICN Pharmaceuticals.

\section{Proteins}

Bovine carboxylase was purified as previously described, concentrated by chromatography on SP-Sepharose (Pharmacia) and its concentration was estimated using the specific activity of the purified protein according to Wu et al (1). The proteins proFIX and proFIX(GLA) expressed in chinese hamster ovary cells were kindly provided by Mary Switzer of the Purification Process Development Department at Genetics Institute Inc. (Andover, MA). Human plasma factor IX was purchased from Haematological Technologies (Essex Jct, VT). The factor IX propeptide (proFIX19) was synthesized by Dr Frank Church (University of North Carolina at Chapel Hill). The chemically synthesized mature form of human osteocalcin (amino acids 1 to 49) was provided by Dr. Berry A.M. Soute (Maastricht University, The Netherlands). Oligonucleotides for cloning and mutagenesis were from Oligos Etc. Inc., (Guilford, CT)

\section{Construction of expression vectors}

The multifunctional expression vector phagemid pMc292 described previously ${ }^{24}$ was used for both mutagenesis and expression of foreign peptides in $E$. coli. This phagemid contains an insert that codes for the propeptide and first 41 amino acids of the gladomain of human factor $\mathrm{IX}$. The methionine at amino acid 19 is mutated to isoleucine as found in mouse factor $1 X$. Arginines at -4 and -1 are mutated to asparagine and serine respectively. Initially a vector was constructed that contained the gene 10 sequence folowed by the factor $\mathrm{IX}$ propeptide/gla-domain/egf1/egf2 domains in the pMc292 phagemid. This was done using oligonucleotides 5'-T GAG AGA GAA TGC ATA GAA AAG TGT-3" and 5'-GGA GGA TCC TAT GCT GGT TCA CAG GAC T-3' to 
amplify a fragment from the human factor $1 X$ cDNA that engineers a Nsil $I$ site at the 5 end, a BamHI site at $3^{\prime}$ end and codes for amino acid residues 20-127 of human factor NX. This fragment was digested with Nsi U/BamHI and ligated into the Nsi VBamHI digested pMc292 phagemid. The resulting vector is referred to as pMc292(1X-18 to 127) and was used for further mutagenesis and cloning.

In vitro mutagenesis

All in witro mulagenesis were performed by the Uracil method ${ }^{29}$ using single stranded DNA prepared using M13KO7 ${ }^{30}$. The FIXproGLA46 construct was generated by inserting a stop codon after amino acid 46 using oligonucleotide 5"-CAG TAT GTT TAA GGA TCC CAG TGT GAG. The FIXGLA46 construct was created by using oligonucleotide 5'ATT ATC GCT AAG TAC GCC ATG TAT AAT TCA GGT AAA CTC GAG-3' and the original pMc292 phagemid to loop out from Alanine at -18 to the Serine at -1. The FIXproNon-GLA construct was generated by using oligonucleotide $5^{\prime}-\mathrm{TCT}$ TGA ATC AGC CAA AGA GCG GAA CCT TGA GAG AGA ATG TAG AGG AGA AAA GTG TA-3' which loops out from tyrosine at position 1 to the middle of the codon at position 12 which codes for glycine. The oligonucleotide also replaces a stop codon that would occur 8 amino acids after the end of the propeptide with a glutamate and changes a lysine at postion 9 to glutamate. This introduces a frameshift that results in a construct that codes for the factor $1 X$ propeptide attached to a 45 amino acid non-gladomain sequence.

\section{Expression, purification and characterization of peptides}

The various peptides were prepared as described previously 24 with the following modifications. The inclusion bodies were isolated from either a $4 \mathrm{~L}$ culture or a $5 \mathrm{~L}$ culture prepared with a BioFlo llc fermentor (New Brunswick Scientific). Peptides which contained a tryptophan residue (FIXproGLA46 and FIXGLA46) were digested with cyanogen bromide in $72 \%$ trifluoroacetic acid in place of trichloroacetic acid to minimize oxidation of the tryptophan residues. After cyanogen bromide cleavage, the dried down peptides were resuspended in $50 \mathrm{ml}$ of $8 \mathrm{M}$ Guamidine-HCl. The peptides were 
sulfonated by the addition of $0.15 \mathrm{~g}$ sodium tetrathionate, $0.3 \mathrm{~g}$ sodium sulfite and adjustment of the $\mathrm{pH}$ to 9.0 with ammonium hydroxide and incubating at room temperature for $16 \mathrm{hr}$. The sulfonated peptides were then dialyzed against three changes of $25 \mathrm{mM}$ MOPS $\mathrm{pH} 8.0,10 \mathrm{mM} \mathrm{NaCl}$ to precipitate the gene 10 fragments while the target peptides remained in solution. The gene 10 fragments were removed by centrifugation at $12,000 \mathrm{~g}$ for $15 \mathrm{~min}$. The supernatant was loaded on a DEAE-Sepharose CL-6B (Sigma) column and the target peptide was eluted by the addition of $25 \mathrm{mM}$ MOPS pH $8.0 / 250 \mathrm{mM} \mathrm{NaCl}$. Sulfonation was reversed by incubating the eluted peptides at room temperature for three hours with $100 \mathrm{mM}$ dithiothreitol. The peptides were further purified by reversed-phase HPLC using a Rainin $0.46 \times 50 \mathrm{~mm}$ C18 column (83-203-F5). Peptides were eluted using a linear 10 minute gradient ( $1 \mathrm{ml} / \mathrm{min})$ of $0 \%$ Buffer B $(0.1 \%$ TFA) to $100 \%$ Buffer B $(90 \%$ Acetonitrile/0.1\% TFA). The peptides were dried by rotary evaporation.

\section{Confirmation of peptides by electrospray ionization mass spectroscopy}

The molecular mass of each peptide was determined using a Fisons-VG Quattro BQ triple quadropole mass spectrometer equipped with a pneumatically assisted electrostatic ion source operating at atmospheric pressure. Samples were reconstituted in $50 \%$ aqueous acetonitrile containing formic acid $(1 \% \mathrm{v} / \mathrm{v})$ and were introduced by loop injection into a stream of $50 \%$ aqueous acetonitrile flowing at $6 \mu \mathrm{L} / \mathrm{min}$. Mass spectra were acquired in the multichannel analyser (MCA) mode from m/e 700-1400 with a scan time of 10 seconds. The mass scale was calibrated with horse heart myoglobin $\left(M_{r}\right.$ 16951.48) with a resolution corresponding to a peak width at half height of $1.0 \mathrm{Da}$ for $\mathrm{m} / \mathrm{e} 893$. The mass spectra were transformed to a molecular mass scale using software supplied by the manufacturer.

\section{Kinetics of carboxylation of propeptide containing peptides}

Reactions $(125 \mu \mathrm{L})$ were conducted at $17^{\circ} \mathrm{C}$ for $8 \mathrm{hr}$ with indicated amounts of purified bovine carboxylase and $25 \mathrm{mM}$ MOPS pH 7.4, $0.5 \mathrm{M} \mathrm{NaCl}, 0.16 \%$ CHAPS, $0.16 \%$ phosphatidyl choline, $222 \mu \mathrm{M}$ vitamin $\mathrm{K}$ hydroquinone, $6 \mathrm{mM}$ DTT and $5 \mu \mathrm{Ci}$ of 
$\mathrm{NaH}^{14} \mathrm{CO}_{3}$ (specific activity, $54 \mathrm{mCi} / \mathrm{mmol} ;$ / $\mathrm{CN}$ Corp). A final concentration of $60 \mathrm{nM}$ free factor $\mid X$ propeptide from the purified carboxylase is also present. Reactions were quenched by the addition of $75 \mu \mathrm{L}$ of $1 \mathrm{~N} \mathrm{NaOH}$ and transferred to vials containing 1 $\mathrm{ml}$ of $5 \%$ trichloroacetic acid. Samples were gently boiled to remove unincorporated ${ }^{14} \mathrm{CO}_{2}$ and total incorporation was determined by scintillation counting. Previous studies on the kinetics of ${ }^{14} \mathrm{CO}_{2}$ incorporation into representative peptides of the vitamin K-dependent substrates have employed short incubation times $(<1 \mathrm{hr})$ to measure carboxylation. A previous study along with this work indicate that the time course of carboxylation of peptides with an attached propeptide demonstrates a biphasic burst with an initial rapid pre-steady state phase followed by a slower linear steady state phase ${ }^{25}$. Therefore, to measure the steady state kinetics of ${ }^{14} \mathrm{CO}_{2}$ incorporation, we used prolonged incubation times such that we were measuring the steady state rather than the pre-steady state rate. Inhibition experiments were done under the same reaction conditions and incubation times as above. For inhibition studies with proFIX(GLA), control experiments were done in the absence of substrate to account for traces of uncarboxylated or partially carboxylated proFIX in the proFIX(GLA) preparation. The ${ }^{14} \mathrm{CO}_{2}$ incorporation in the absence of substrate was small $(<8 \%)$ compared to $\mathrm{XX}-18$ to 46 carboxylation and was subtracted from the activity in the presence of substrate.

Determination of the extent of FIXProNon-GLA carboxylation of by mass spectrometry The number of carboxylations of the FIXproNon-GLA peptide was determined by a similar method to that used previously to demonstrate processivity in FIXproGLA41 carboxylation ${ }^{25}$. Briefly, a $5 \mathrm{ml}$ carboxylation reaction containing $20 \mathrm{nM}$ purified bovine carboxylase, $25 \mathrm{mM}$ MOPS pH 7.4, $0.15 \mathrm{M} \mathrm{NaCl}, 0.16 \%$ CHAPS, $0.16 \%$ phosphatidyl choline, $120 \mu \mathrm{M}$ vitamin $\mathrm{K}$ hydroquinone, $200 \mu \mathrm{Ci}$ of $\mathrm{NaH}^{14} \mathrm{CO}_{3}$ (specific activity, 54 $\mathrm{mCi} / \mathrm{mm}$; ICN Corp) and $2.5 \mu \mathrm{M}$ FIXproNon-GLA peptide were incubated at $17^{\circ} \mathrm{C}$ and were supplemented with an additional $120 \mu \mathrm{M}$ vitamin $\mathrm{K}$ hydroquinone after 12 hours. After $17 \mathrm{hr}$ the reaction was quenched by acidification with acetic acid to remove free ${ }^{14} \mathrm{CO}_{2}$ and neutralized with sodium hydroxide. The reaction was diluted 20 -fold, 
buffered to $\mathrm{pH} 5.0$ and bound to $1 \mathrm{ml}$ of SP-sepharose and eluted with $0.5 \mathrm{M} \mathrm{NaCl}$. The labeled material was loaded on a $0.46 \times 50 \mathrm{~mm}$ Rainin C18 HPLC column and eluted at a flow rate of $1 \mathrm{ml} / \mathrm{min}$ with a linear gradient from $0 \%$ acetonitrile $/ 0.1 \%$ trifluoroacetic acid to $100 \%$ acetonitrile $/ 0.1 \%$ trifluoroacetic acid. Fractions along the elution gradient were collected and those containing ${ }^{14} \mathrm{CO}_{2}$ incorporation above background were pooled and dried by rotary evaporation. The dried down sample was resuspended in $20 \mu \mathrm{L}$ of $10 \mathrm{mM}$ ammonium lhydroxide. Samples were then analyzed by online mass spectrometry as described previously ${ }^{25}$.

\section{Kinetics of carboxylation of gla-domains}

Reactions were performed at $17^{\circ} \mathrm{C}$ for $1 \mathrm{hr}$ with $4 \mathrm{nM}$ purified bovine carboxylase, 25 mM MOPS pH 7.4, 0.5 M NaCl, $0.16 \%$ CHAPS, $0.16 \%$ phosphatidyl choline, $0.6 \mathrm{M}$ ammonium sulfate, $20 \mu \mathrm{M}$ proFIX19, $222 \mu \mathrm{M}$ vitamin $\mathrm{K}$ hydroquinone, $6 \mathrm{mM} \mathrm{DTT}$ and $5 \mu \mathrm{Ci}$ of $\mathrm{NaH}^{14} \mathrm{CO}_{3}$ ('specific activity, $54 \mathrm{mCi} / \mathrm{mmol}$; ICN Corp). Unlike the time course of propeptide containing peptides, the time course of carboxylation of the gla-domains did not demonstrate a burst but rather was linear during the $1 \mathrm{hr}$ reaction course. 


\section{Results}

\section{Expression "purification and identification of peptides}

All peptides were expressed in E. Coli, purified by high pressure liquid chromatography, and verified by ion spray mass spectrometry. FIXpro-NonGLA is expressed as a 63 amino acid peptide, but cleavage by cyanogen bromide removes 11 amino acids from its C-terminus: The resulting peptide is 52 amino acids with an approximately $1: 1$ mixture of the homoserine or homoserine lactone residue at the C-terminus. (Table 1). The experimental molecular mass for each of the peptides is as follows: FIXproGLA46 is $7645.7 \pm 0.4$ daltons (predicted: 7646.4 ), FIXGLA46 is $5625.31 \pm 1.96$ daltons (predicted: 5626.1 ) and FIXproNon-GLA $5938.7 \pm 0.29$ daltons (predicted: 5938.6 ) for the homoserine form and $5920.49 \pm 0.57$ (predicted 5920.6) for the homoserine lactone form.

\section{Table 1}

Sequences of Factor IX and Osteocalcin-Based Peptides ${ }^{\text {a }}$

\begin{tabular}{|c|c|c|}
\hline FIXPROGLA46 & AVFLDHENANKKLLOPKS. & YNSGKLEEFVOGNLERECIEEKCSFEEAREVFENTERTTEFWKOYV \\
\hline FIXOLA46 & & YNSGKLEEFVOGNLERECIEEKCSFEEAREWFENTERTTEFWKQY \\
\hline Osteocalcin & & YLYOWLGAPVPYPDPLEPRREVCELNPOCDELADHIGFQEAYRRFYGPU \\
\hline FlXproNonGLA & AVILLOHENANKLIMOPKS. & GTLRENWEEKSWVLKKHEKFLKTLKEQLNFGSShS \\
\hline
\end{tabular}

The propeptide sequence is underlined. Known carboxylated glutamates in factor $\mid X$ and osteocalcin and potentivil carboxyletion siles in FIXproNonGla are indicated in boldface lype. hS stands for homoserine $f$ thomostrine lactome

Inhibition of carboxylation by free propeptide and proFIX(GLA)

To ascertain the importance of the propeptide in substrate recognition by the carboxylase, we examined the effect of free propeptide (proFIX19) on carboxylation of a propeptide/gla-domain (FIXproGLA41) peptide. As seen in figure 1, proFIX19 acts as a competitive inhibitor of FIXproGLA41 carboxylation with $a K_{i j}=0.22 \mu \mathrm{M} \pm 0.10 \mu \mathrm{M}$. Competitive inhibition indicates that binding of free propeptide to the propeptide binding 
site of the carboxylase prevents association of the FIXproGLA41 substrate with the carboxylase. This is consistent with an initial interaction of the carboxylase with its substrate through the propeptide sequence rather than the gla-domain or glutamic acid residues themselves. In addition, we find that carboxylated factor $\mathrm{X} X$ with the propeptide still attached (proFIX(GLA)), is a product inhibitor of a propeptide/gla-domain peptide carboxylation with a $K_{i} 0.40 \mu \mathrm{M} \pm 0.07$, similar to that observed for free propeptide. In contrast, plasma factor $\mid X$, which does not contain the amino-terminal propeptide extension, is unable to inhibit carboxylation at the concentrations tested (Figure 2 ). Therefore, product inhibition by proFIX(GLA) is conferred by the propeptide and is a result of preventing access of the substrate to the propeptide binding site.

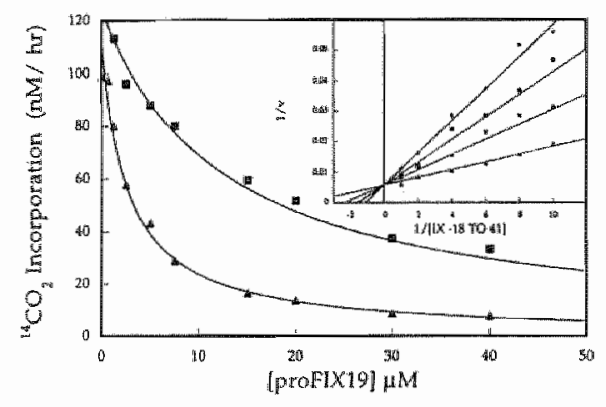

Figura 1: Fres Propeptide is Competiture Iminibitor of FIxproGilat 1 Carboxylation. The effect of the propeplide (prof $X 19$ ) on carboxylation was extamined with 1 , MM (A) and 5 uM (B) FIXproGLAA1 at $17 \mathrm{C}$ for 8 hr with -10 nM purifiad bovine carboxylase. Data were fit by nonlinear regression and lines were drawn according to the aquation for compettive intibition $(35)$ using Wmax $=124$ 年 $15 \mathrm{nMhhr} \mathrm{K}_{\mathrm{m}}=0.10 \pm 0.05$ wh and $K_{i}=0.22 \pm .14 \mathrm{H} / \mathrm{M}$. Inset: Lineweaver-Burke ptot of the effect of $0.068 \mathrm{yH}(\mathrm{M})$.

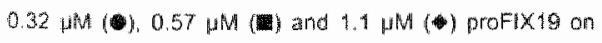
carboxylation of FIXproGLAA1. Lines were drawn Using the equation for finear competstive inhibition with Vmax $=174 \pm$ $16 \mathrm{nM} / \mathrm{mr}, K_{\mathrm{ra}}=0.16 \pm 0.05$ H M and $K_{6}=0.19 \pm 0.04 \mu \mathrm{M}$.

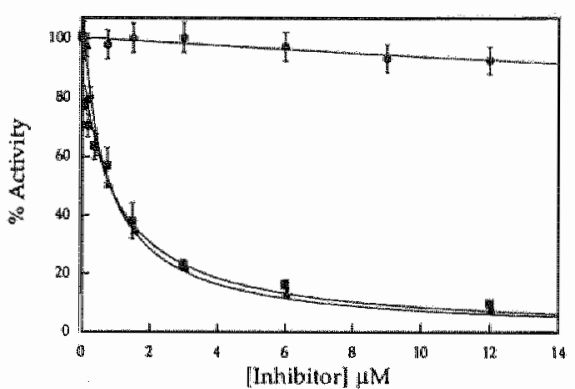

Figum 2: $\quad$ Fully Carbomylated fractor IX with the Propesplides Sthi Atiacher Inhibite FiXproGLA46 Carboxylation. The effect of free propeptide (A),

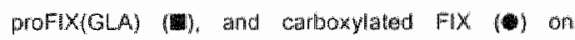
FiXproGLA46 carboxylation was examined al $17{ }^{20} \mathrm{C}$ for 8 Fr with 10 nM purified bovine carboxylase. Indicalded data points are the average of at larst two independent expeniments and the error bars indicate the stardard devalitan. Lines were drawn whth the equation for competive inhibilion with $K_{t F}=0.21 \pm 0.14$ and $K_{i}=0.29$

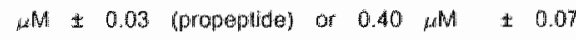
(profix (OLA) 


\section{Table 2}

Kinetic Constants for ${ }^{14} \mathrm{CO}_{2}$ Incorporation for Peptide Substrates with Purified Bovine Carboxylase

\begin{tabular}{|c|c|c|c|}
\hline Substrate & $K_{\mathrm{rm}}^{\mathrm{apg}} \pm S \mathrm{SD}^{\mathrm{b}}(\mu M)$ & \multicolumn{2}{|c|}{$V_{\max } \pm S D^{b}(n / M / h)$} \\
\hline FIXproGLA41 & $0.49 \pm 0.10$ & 173 & \pm 45.3 \\
\hline FIXproGLA46 & $0.27 \pm 0.09$ & 191 & \pm 28.5 \\
\hline Profix & $0.36 \pm 0.04$ & 169 & \pm 15.0 \\
\hline FIXproNonGLA & $0.46 \pm 0.18$ & 63 & \pm 27.6 \\
\hline
\end{tabular}

a Rections were performed as detalled in methods using at least 10 concentrations of each substrate. Kinetic parameters were determined by fitting the data to the Michaelis-Menten equation by non-linear regression.

b Vatues are \pm standard deviation, obtained from at least three independent deteminations.

Kinetics of factor $I X$ based peptides with purified bovine carboxylase

As shown in table 2, peptides with an attached propeptide: FIXproGLA41, FIXproGLA46 and proFIX demonstrate similar apparent $K_{m}$ values $(0.2$ to $0.4 \mu \mathrm{M})$ which are $\sim 6000$ fold lower than the $K_{m}$ observed for the pentapeptide substrate FLEEL. The proFIX peptide is the full length uncarboxylated factor IX with the propeptide still attached and should be analogous to the native in vivo substrate of the carboxylase. Therefore the similar $K_{m}$ values and carboxylation rates of the propeptide/gla-domain peptides to the full length factor IX molecule suggest that in our in vitro system these peptides are good models for the physiological substrate of the carboxylase and elements beyond the propeptide and gla-domain are not required for carboxylation.

To examine whether the propeptide alone is adequate to direct carboxylation of a glutamate-containing substrate, we expressed in E. Coll a peptide which contains the FIX propeptide sequence followed by a non-gla-domain sequence. This sequence (Table 1). FIXpro-NonGLA, although containing five glutamic-acid residues, lacks the highly conserved sequences characteristic of the gla-domains of the vitamin $\mathrm{K}$ dependent blood proteins. As can be seen in table 2, FIXpro-NonGLA is carboxylated with a $K_{m}$ of $0.46 \mu \mathrm{M}+/-0.18$ which is similar to the range observed for the factor $I X$ 
propeptide/gla-domain peptides. The observed Vmax for the FIXpro-NonGLA peptide is approximately three-fold lower than that observed for the FIX propeptidelgla-domain peptides.

\section{Extent of carboxylation of the FIXpro-NonGLA peptide}

To ascertain if the propeptide alone is able to direct multiple carboxylations of an attached substrate containing glutamates, we determined the extent of carboxylation of the FIXpro-NonGLA peptide. FIXpro-NonGLA was carboxylated in a preparative reaction with a large substrate excess over the enzyme, extracted by batch absorption, and ellution from SP-sepharose. The peptide was isolated by reverse phase HPLC and all the fractions containing ${ }^{14} \mathrm{C}$ label were pooled. Online mass spectrometry of the labeled fraction is presented in figure 3 and shows a distribution of carboxylation states from 0 to 4 carboxylations. The uncarboxylated FIXpro-NonGLA is present as two roughlly equal mass forms corresponding to the homoserine lactone at the C-terminal residue (5920.6 daltons) or the free homoserine form (5938.5 daltons). Each carboxylation increases the mass $45.4 \pm 0.2$ daltons as demonstrated previously ${ }^{25}$. Doublets corresponding to each carboxylation state of both the homoserine lactone and homoserine isomer are observed. We were unable to identify peak(s) conforming to the expected mass of the 5 carboxylation state. The major product of the reaction is the uncarboxylated form consisting of $>75 \%$ of the total peptide. The one, two, and three carboxylation states are present at $\sim 5 \%$ each and the four carboxylation states comprises $10 \%$ of the total peptide.

The observed distribution of carboxylation states is consistent with a processive mechanism in which multiple carboxylations are catalyzed in a single binding event. The majority of the FIXpro-NonGLA peptide is uncarboxylated, while the fraction of peptide that is carboxylated appears to be multiply carboxylated with the 4 carboxylation state being the major form. Although other less likely formal mechanisms could give rise to the carboxylation profile we observe, the FIXpro-NonGLA carboxylation profile is consistent with a processive mechanism. This profile is also consistent with that shown in a previous study which demonstrated that the 
FIXproGLA41 peptide is processively carboxylated ${ }^{25}$. Therefore, the propeptide alone is able to confer processive carboxylation of an attached substrate that lacks the highly conserved gla-domain sequences found in the vitamin K-dependent blood coagulation proteins.

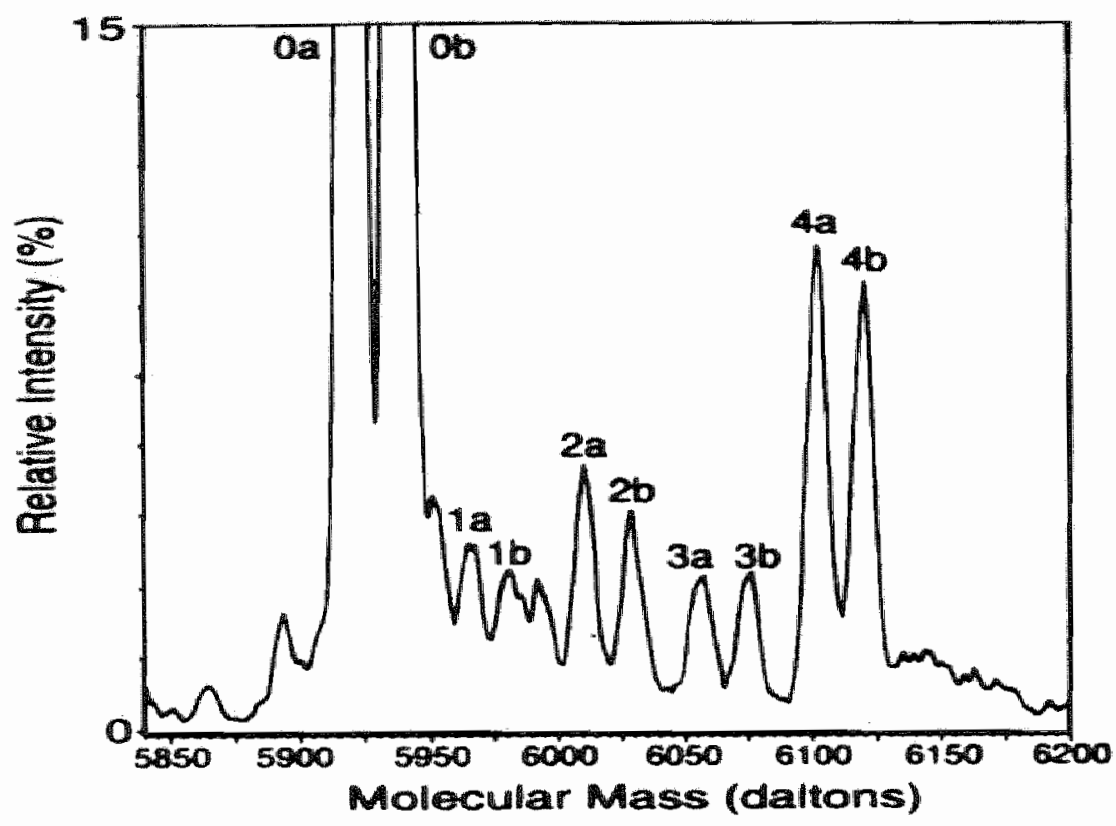

Figure 3: $\quad$ Mass Spectroscopic Analysis of Preparative FIXproNonGLA Carboxylation Reaction. Labeled fractions from preparative reaction and purified by reverse phase HPLC were analyzed by online mass-spectrometry as described in methods. The numbers above each peak indicate the number of carboxylations required to yield the observed molecular mass of the homoserine lactone (a) and homoserine form (b). The relative intensitiy for the uncarboxylated homoserine lactone form (0a) was $89 \%$ and the homoserine form (Ob) was $100 \%$.

Kinetics of Carboxylation of gla-domains of vitamin K-dependent proteins In contrast to the peptides with an attached propeptide, we find that the gla-domain of factor IX (FIXGLA46) alone is a poor substrate for the carboxylase. For example, in the presence of $20 \mu \mathrm{M}$ of factor IX free propeptide, we estimate its $K_{m}$ to be $140 \pm 32 \mu \mathrm{M}$ 
(Table 3) as compared to $0.2 \mu \mathrm{M}$ for FIXproGLA46. Because of solubility problems, the highest concentration of substrate that could be achieved was $250 \mathrm{WM}$ which is two-fold greater than its apparent $K_{\mathrm{m}}$.

\section{Table 3}

Kinetic Constants for ${ }^{4} \mathrm{CO}_{2}$ Incorporation for Gla-domain Peptide Subtrates with Purified Bovine Carboxylase

\begin{tabular}{lll}
\hline \multicolumn{1}{c}{ Substrate $^{\mathrm{a}}$} & $\mathrm{K}_{\mathrm{m}}^{\mathrm{app}} \pm \mathrm{SD}^{\mathrm{di}}(\mu \mathrm{M})$ & $\mathrm{V}_{\max } \pm \mathrm{SD}^{\mathrm{m}}(\mathrm{nM} / \mathrm{h})$ \\
\hline FLEEL & $1190 \pm 300$ & $14700 \pm 1810$ \\
Osteocalcin & $0.608 \pm 0.07$ & $3610 \pm 82.6$ \\
FIXGLA46 & $\geq 140 \pm 32$ & $3030 \pm 202$ \\
\hline
\end{tabular}

\footnotetext{
3 Reactions were performed as detailed under Experimental Procedures using at least 8 concentrations of each substrate. Kinetic parameters were detemined by fitting the data to the Michaelis-Menten equation by nom-linear regression. The ligighest concentration of substrate used for FXGLA46 was $250 \mu M_{1}$ so the value obtained is a Hower estimate, therefore the real value may be higher.

Values are \pm standard deviation, obtained from at least three independent determinations.
}

Therefore, the actual $\mathrm{K}_{\mathrm{m}}$ may be somewhat higher. Nevertheless, the apparent affinity of the FIXGLA46 peptide is clearly weaker ( $\sim 500$ fold) than that observed for the corresponding peptide with an attached propeptide (FIXproGLA46). We also compared the carboxylation of the FIXGLA46 peptide to that of the pentapeptide substrate FLEEL and the uncarboxylated mature form of osteocalcin. The apparent $K_{\mathrm{rm}}$ for the small glutamate substrate FLEEL is $1190 \mathrm{uM} \pm 300 \mathrm{uM}$, similar to previously reported values using purified carboxylase (4). The uncarboxylated osteocalcin has a $K_{\mathrm{m}}=0.61 \mathrm{uM} \pm 0.07$ uM (Table 3), nearly identical to the value obtained by Benton et al ${ }^{28}$. Therefore the apparent $K_{\mathrm{m}}$ for the FIXGLA46 peptide is at least 230 -fold higher than observed for uncarboxylated osteocalcin and is closer to the range observed for small glutamate substrates. 


\section{Discussion}

Our studies indicate that the propeptide is the initial binding site, confers substrate affinity, and is sufficient to direct multiple carboxylations in a single binding event (i.e. processive). In contrast to osteocalcin, an attached propeptide is required for efficient association of the gla-domain of factor IX with the carboxylase. Evidence that the initial interaction between the enzyme and substrate is mediated by the propeptide is provided by inhibition studies which indicate that free propeptide is a competitive inhibitor of FIXproGLA41 carboxylation. In addition, carboxylated full length factor IX with the propeptide still attached inhibits carboxyllation of FIXproGLA41 with a Ki similar to free propeptide. Therefore the carboxylation state of the gla-domain do not appear to affect binding of the substrate to the carboxylase through the propeptide. Further evidence for the importance of the propeptide is provided by experiments which show that substrates with a covallently-linked propeptide have similar apparent affinities for the carboxylase. The $K_{m}$ values are in the 0.2 to $0.5 \mu \mathrm{M}$ range whether the propeptide is followed by just the gla-domain (FIXproGLA41), the gla-domain and hydrophobic stack domain (FIXproGLA46), the rest of the factor IX molecule (proFIX), or a non-gladomain sequence containing glutamic acid residues (FIXproNon-GLA). Therefore, regions beyond the propeptide do not affect the apparent binding affinity of the carboxylase for its substrate.

An amino-terminal propeptide alone is also able to direct processive carboxylations of an attached glutamate containing region without the requirement for the highly conserved sequences present in the glla-domains of the vitamin K-dependent blood proteins. This is demonstrated by the carboxylation studies of the FIXproNonGLA peptide, which contains the factor IX propeptide but not the highly conserved gladomain sequences characteristic of the vitamin K-dependent proteins. The pattern of carboxylation of FIXproNon-GLA peptide is consistent with the processive mechanism previously observed for the factor IX propeptide/gla-domain peptide ${ }^{25}$. In vivo, processivity would be expected to be highly efficient, with molecules undergoing carboxylation being fully carboxylated. With FIXproNon-GLA, we find that $40 \%$ of the peptide that undergoes carboxylation is fully carboxylated, similar to the fraction fully 
carboxylated with the FIXproGLA41 ${ }^{25}$. Thus, the FIXproNon-GLA peptide is processively carboxylated in a manner similar to the factor IX propeptide gla-domain peptide, indicating that the gla-domain sequences are not required for processivity. Therefore the binding affinity of the propeptide and the propeptide's ability to activate the carboxylase are sufficient to allow multiple carboxylations of factor IX during one binding event.

The reduced rate of carboxylation of FIXproNon-GLA is also likely a consequence of a processive mechanism of carboxylation. For processivity to occur, the rate of release of the substrate must be slower than the rate of carboxylations. For example, if propeptide dissociation were rate limiting, the observed rate of carboxylation would be proportional to the number of glutamates that can be carboxylated in a single enzyme turnover. Thus, a substrate with fewer than twelve carboxylation sites would undergo fewer carboxylations in a single enzyme turnover, and would appear to be carboxylated at a proportionally slower rate. This is consistent with our observations of the $\sim 3$-fold lower $V_{\max }$ for FIXproNon-GLA peptide compared to FIXproGLA41. Recently, it has been shown that a chimera containing the prothrombin propeptide and a normally uncarboxylated glutamate rich region of thrombin is efficiently carboxylated in mammalian cell culture ${ }^{31}$. This finding, along with our studies, indicates that both in vitro and in vivo, the propeptide alone can direct multiple carboxylations in an attached region containing glutamates.

The sequences of the gla-domains of the vitamin K-dependent proteins are highly conserved, therefore it seems plausible that they play an important role in carboxylation. For example, a conserved sequence (Glu-X-X-X-Glu-X-Cys) has been identified within the gla-domains of all known vitamin K-dependent proteins ". In addition, the widely used substrate FLEEL was derived from a subset of gla-domain sequences. Although decarboxylated prothrombin was reported to be a poor substrate for the carboxylase ${ }^{32}$, several studies have shown that osteocalcin without an attached propeptide is an excellent substrate ${ }^{26,27}$. Moreover, in the presence of free factor $X$ propeptide, osteocalcin with a covalently linked propeptide has only a modestly llower 
$K_{m}$ than osteocalcin without an attached propeptide ${ }^{23}$. Therefore we examined whether the gla-domain of factor $I X$ has a similar recognition site for the carboxylase.

Our results indicate that the gla-domain alone of factor IX has a poor apparent affinity for carboxylase and that an attached propeptide is required for high affinity binding of factor $\mathrm{XX}$. The $K_{\mathrm{m}}$ for the FIXproGLA46 is 500 -fold lower than observed for the gla-domain alone (FIXGLA46), whereas the $K_{m}$ for osteocalcin without an attached propeptide is in the same range as covalently linked propeptide substrates. The propeptide of osteocalcin contains a glycine at the highly conserved - 10 position, which is alanine in all ather known vitamin K-dependent proteins. It has been shown that substitution of glycine for alanine at the -10 position increases the $K_{m}$ of the FIXproGLA41 peptide 30 -fold ${ }^{16}$; therefore the osteocalcin propeptide may possess a significantly weaker affinity for the carboxylase than the factor IX propeptide. Consequentlly, osteocalcin and factor IX may have evolved different binding sites which confer substrate recognition and may be carboxylated by distinct mechanisms. Further studies will be required to verify this distinction and understand its physiological significance.

Binding of physiologically relevant substrates for the vitamin K-dependent carboxylase proceeds through a multi-step pathway. With factor $M$, the initial binding step is through the propeptide which localizes the glutamates-to-be-carboxylated in the vicinity of the active site. Subsequent interactions are then required between the glutamates-to-be-carboxylated and the active site. Our studies with FIXproNon-GLA indicate that the position of the glutamates or the gla-domain structure is not required for multiple processive carboxylations, but we can not rule out the possibility that the characteristic gla-domain structure may direct the specificity or enhance the efficiency of carboxylation. The gla-domain sequences may play a role in determining which glutamates are carboxylated. For example, residues immediately surrounding a glutamate-to-be-carboxylated may influence its affinity for the active site once it is localized there by binding at the propeptide. Evidence for this is seen in the effect of adjacent amino acids on the activities of small glutamate containing peptides ${ }^{33}$ and with partially or uncarboxylated glutamates in osteocalcin and matrix gla protein ${ }^{34}$. The 
domain structures of all the vitamin K-dependent blood proteins are highly similar; therefore, even in the uncarboxylated partially unfolded state, these domains may possess secondary structure that lacalizes all the glutamates-to-be-carboxylated proximal to the active site. Spatial orientation and physical distance of glutamates-to-be-carboxylated from the active site may also play a pivotal role in whether a particular glutamate is modified. With FIXproNon-GLA, only four of the five glutamates are carboxylated, therefore absence of structure that localizes one of the glutamates proximal to the active site or adjacent amino acids that influence a particular giutamate's affinity for the active site may prevent the fifth modification. The glutamates in the gla-domains of the vitamin K-dependent proteins may be ideally positioned for modification or carboxylation could induce a structural change which enhances subsequent modifications (i.e. cooperativity). Alternatively, native substrates may have an active release mechanism in which the accumulation of negative charge or carboxylation itself could cause a structural change in the gla-domain that signals that carboxylation is complete and directs product release. In such circumstances, the carboxylated product would be expected to have a weaker affinity for the enzyme than free propeptide or the uncarboxylated substrate. This is not observed with proFIX(GLA) in our in vitro system, which suggests that completion of carboxylation itself is not a release mechanism. We can not rule out the possibility that other accessory proteins absent from our in witro assays may be critical for signaling the completion of carboxylation in wivo.

In conclusion, this work demonstrates that with an in witro system using purified components, peptides containing the propeptide and gla-domain are good models for the physiological substrate in carboxylation by the vitamin K-dependent carboxylase. The initial interaction of the vitamin $K$-dependent carboxylase with its substrate is through the propeptide which confers the perceived affinity of the enzyme for its substrate without apparent influence of the gla-domain or regions beyond the gladomain. Binding through the propeptide is also adequate to direct multiple carboxylations in a single binding event without the requirement for the highly conserved sequences in the gla-domains of the vitamin K-dependent proteins. Further 
studies will be required to understand steps beyond the initial interaction of the propeptide with the carboxylase such as the interaction of the glutamates with the active site and product release and dissociation steps in the mechanism of efficient and processive carboxylation by the vitamin K-dependent carboxylase.

\section{Acknowledgments}

The authors wish to thank Dr. Robert Stevens at the Duke Children's Hospital Mass Spectrometry facility for mass spectrometry analysis and Mary Switzer of Genetics Institute Inc. for providing the proFIX and proFIX(GLA) peptides.

This work was supported by National Institutes of Health grant HL06350 (D.W.S.). 


\section{References}

1. Wu, S. M. Morris, D. P. \& Stafford, D. W. identification and purification to near homogeneity of the vitamin K-dependent carboxylase. Proc Nafl Acad Sci USA 88, 2236-2240 (1991).

2. Wu, S. M. Cheung, W. F. Frazier. D. \& Stafford, D. W. Cloning and expression of the cDNA for human gamma-glutamyl carboxylase. Science 254, 1634-1636 (1991).

3. Rehemtulla, A. et al. In vitro and in viwo functional characterizatian of bovine vitamin $K$-dependent garmmacarboxylase expressed in Chinese hamster ovary cells. Proc Nall Acad Sci USA 90, 4611-4615 (1993).

4. Morris, D. P., Soute, B. A., Vermeer, C. \& Stafford, D. W. Characterization of the purified vitamin Kdependent gamma-glutamyl carboxylase. J Biol Chem 268, 8735-8742 (1993).

5. Suttie, J. W. Vitamin K-dependent carboxylation of glutamyll residues in proteins. Biofactors 1, 55-60 (1988).

6. Furie, B. \& Furie, B. C. Molecular basis of vitamin K-dependent gamma-carboxylation. Blood 75, 1753$1762(1990)$.

7. Suttie, J.W. Synthesis of vitamin K-dependent proteins. Faseb /7, 445-452 (1993).

8. Price, P. A., Urist, M. R. \& Otawara, Y. Matrix Gla protein, a new gamma-carboxyglutamic acid-containing protein which is associated with the organic matrix of bone. Biochem Biophys Res Commun 117, 765-771 (1983).

9. Manfioletti, G., Brancolini, C.. Avanzi, G. \& Schneider, C. The protein encoded by a growth arrest-specific gene (gas6) is a new member of the vitamin K-dependent proteins related to protein $S$, a negative coregulator in the blood coagulation cascade. Mol Cell Biol 13, 4976-4985 (1993).

10. Kulman, J. D., Harris, J. E., Haldeman, B. A. \& Davie, E. W. Primary structure and tissue distribution of two novel proline rich gamma carboxyglutarnic acid proteins. Proc Natl Acad Sci USA 94, 9058-9062 (1997).

11. Price, P.A., Fraser, J.D. \& Metz Virca "G. Molecular cloning of matrix Gla protein: implications for substrate recognition by the vitamin K-dependent gamma-carboxylase. Proc Natl Acad Sci USA 84, 8335-8339 (1987).

12. Jorgensen, M. J. ef al. Recognition site directing vitamin K-dependent gamma-carboxylation resides on the propeptide of factor IX. Cell 48, 485-191(1987).

13. Foster, D. C. et al. Propeptide of human protein C is necessany for gamma-carboxylation. Biochemistry 26. 7003-7011 (1987).

14. Rabiet, M. J.. Jorgensen, M. J., Furie, B. \& Furie, B. C. Effecl of propeptide muttations on post-1ranslational processing of factor $\mathrm{XX}$. Evidence that beta-hydroxylation and gammatcarboxylation are independent ewents. $J$ Biol Chem 262, 14895-14898 (1987).

15. Huber. P. et al. Identification of amino acids in the gamma-carboxylation recognition site on the propeptide of prothrombin. $J$ Biol Chem 265, 12467-12473 (1990).

16. Chu, K., Wu, S. M. Stanley, T., Stafford, D. W. \& High, K. A. A mutation in the propeptide of Factor IX leads to warfarin sensitwity by a novel mechanism [see comments]. J Cin Invest 98, 1619-1625 (1996).

17. Oldenburg, J. ef al. Missense imutations at ALA-10 in the factor IX propeptide: an insignificant variant in normal life but a decisive cause of bleeding during oral anticoagulant therapy. Br.J Haematol 98, 240-244 $(1997)$ 
18. Ulrich, M. M. Furie, B., Jacobs, M. R., Vemeer, C. B Frie, B. C. Vitamin K-dependant carboxylation. A. Synthetic peptide based upon the gamma-carboxylation recognition site sequence of the prothrombin propephide is an active substrate for the carboxylase in vifra. Jiol Chem 263. 9697-9702 (1988).

19. Kokow, K. J. Roth, D. A , Porter, T. J., Furie, B. C. \& Furie, B. Role of propeptide in witamin K-dependent gammatcarboxylation. Methods Enzymol 222, 435-449 (1993).

20. Kroblow, J. E. 2 Suttie, J. W. Vitamin K-dependent carboxylase. Control of enzyme activity by the "propaptide" region of factor $x$. J Biol Chem 262, 15334-15337 (1987).

21. Soute, B. A. el al. Congenital deficlency of all witamin K-dependent blood coagulation factors due to a defectue witamin Kopendent carboxylase in Devon Rex cats. Thromb Haemost 68, 521-525 (1992). L. S., Furhe, B. C., Furie, B. \& Walsin, C. T. The propeptide of the vitamin Kudependent carboxylase substrate accellerates formation of the gamma-glutamyl carbanion intermediate. Biochemistry 36, 6384$6390(1997)$.

23. Sugiura, 1. Furie, B., Walsh, C. T. \& Furie, B. C. Propeptide and glutamatemcontaining substrates bound to the vitamin $K$-dependent carboxylase convert its vitamin $K$ cpoxidase function from an inactive to an active state. Proc Natl Acad Sci USA 94, 9069-9074 (1997).

24. Wu, S. M. Soute, B. A., Vermeer, C. Statford, D. W. In vitro gamma-carboxylation of a 59-residue recombinant peptide including the propeptide and the gamma-carboxyglutamic aclid domain of coagulation factor $\mathrm{X}$. Effect of mutations near the propeptide cleavage site. $f$ Biol Chem 265, 13124-13129 (1990).

25. Morris, D. P., Stevens, R. D. Wright, D. J. \& Stafford, D. W. Processive postt-translational modification. Vitamin K-dependemt carboxylation of a peptide substrate. J Biol Chem 270, 30491-30498 (1995).

26. Vermeer, C., Soute, B. A., Hendrix, H. \& de Boer wan den Berg. M. A. Decarboxylated bone Gla-protein as a substrate for hepatic vitamim K-dependent carboxylase. FEBS Lett 165, 16-20 (1984).

27. Engelke, J. A. Hale, J. E., Sutte, J. W. \& Prïce. P. A. Viltamin K-dlependent carboxylase: utilization of decarboxylated bone Gla protein and matrix Gla protein as substrates. Biochim Biophys.Acta 1078, 31-34 (1991).

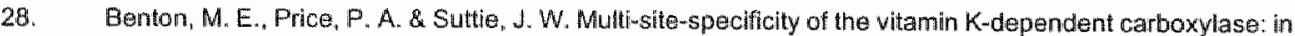
vitro carboxylution of des-gamma-carboxylatad bone Gla protein and Des-gamma-carboxylated pro bone Gla protein. Biochemistry 34,9541-9551 (1995).

29. Kunkal. T. A. Fepld and efficiant site-specific mulagenesis withou phenotypic selection. Proc Nah Acad Sci USA $82,489-492(1985)$

30. Wiatr, J. \& Mossing, J. Production of single-stranded plasmid DNA Methods Enzymol 153, 3-11 (1987).

31. Furie, B. C. ef af. The gamma-carboxylation recognition site is sufficient to direct vitamin K-dependent carboxylation on an adjacent glutamate-rich region of thrombin in a propeptide-thrombin chimera. $I$ Biol Chem 272, 28258-28262 (1997)

32. Soute, B. A.. Vermeer, C., De Metz, M., Hemker, H. C. \& Lijnen, H. F. In vitro prothrombin symthesis from a purfied precursor protein. III. Preparation of an acid-soluble sibstrate for witamin K-dependent carboxylase by imited proteolysis of bowine descarboxyprothrombin. Biochim Brophys Acia 676, 101-107 (1981) 
33. Rich, D. H., Lehman, S. R., Kawai, M., Goodman, H. L. \& Suttie, J. W. Synthesis of peptide analogues of prothrombin precursor sequence 5-9. Substrate specificity of vitamin $K$ dependent carboxylase. $J$ Meo Chem 24, 706-711) (1981).

34. Price, P. (ed. Suttie, J. W.) (Elsevier Science Publishing Co., 1988). 



\section{Chapter 4}

OSTEOCALCIN BINDS TIGHTLY TO THE GAMMA-GLUTAMYL CARBOXYLASE AT A SITE DISTINCT FROM THAT OF THE OTHER KNOWN VITAMIN K-DEPENDENT PROTEINS

Roger J.T.J. Houben ${ }^{\ddagger}$, Dayun Jin $^{\dagger}$, Darrel W. Stafford ${ }^{\dagger}$, Paul Proost ${ }^{\rrbracket}$, Rob H.M. Ebberink $\$$, Cees Vermeer ${ }^{*}$ and Berry A.M. Soute ${ }^{*}$

¿Department of Biochemistry and Cardiovascular Research Instifute, Maastricht University "The Netherlands; " Department of Biology, University of North Carolina at Chapel Hill, Chapel Hill, U.S.A.. " Rega Institute, Department of Molecular Immumology, Catholic University of Leuven, Belgium and ${ }^{\text {s }}$ Perkin - Elmer Netherlands Lid, Nieuwerkerk aan de IJssel, The Netherlands 



\section{Abstract}

Vitamin K-dependent proteins contain a pro-peptide which is required for recognition by the enzyme $y$-glutamylcarboxylase. Substrates used for in vitro carboxylation studies lacking a pro-sequence are characterized by $K_{m}$ values in the millimolar range, whereas the $K_{m}$ for peptides containing a pro-sequence is $3-4$ orders of magnitude lower. Here we report that descarboxy-osteocalcin is an exception in this respect. Using descarboxy-osteocalcin in purified propeptide-free recombinant carboxylase, the $K_{m}$ was found to be $1.8 \mu \mathrm{M}$. Furthermore, osteocalcin was an inhibitor of descarboxy-osteocalcin carboxylation with a $\mathrm{K}_{\mathrm{i}}$ of $76 \mu \mathrm{M}$. In contrast to the other vitamin K-dependent proteins, free propeptides do not inhibit descarboxyosteocalcin carboxylation. Moreover, propeptide-containing substrates were neither inhibited by osteocalcin nor by its propeptide. From our studies we conclude that descarboxy-osteocalcin must have an internal recognition sequence which binds to y-glutamylcarboxylase at a site different from the propeptide-recognition site. 


\section{Introduction}

Osteocalcin, also called bone GLA protein (BGP) ${ }^{1}$, is the most abundant, noncollagenous protein in bone ${ }^{2}$. The mature protein consists of 49 amino acid residues and has a molecular weight of $5700 \mathrm{Da}{ }^{3.4}$. During its biosynthesis osteocalcin undergoes a series of post translational modifications including the conversion of three glutamate residues (Glu) into $\mathrm{V}$-carboxyglutamate (Gla) residues. In this process vitamin $K$ serves as a co-enzyme for $y$-glutamylcarboxylase, an integral membrane protein of $94 \mathrm{kDa}$ residing in the rough endoplasmic reticulum of various mammalian cells ${ }^{5,6}$. Natural substrates for $\mathrm{\gamma}$-glutamylcarboxylase inciude precursors of proteins involved in blood coagulation (prothrombin, factor VII, factor $X_{\text {t }}$ factor $X_{\text {, }}$ protein $\mathcal{C}$, protein $S$ and protein $Z)^{7}$, those involved in tissue mineralization (osteocalcin and matrix Gla protein, MGP) ${ }^{8.9}$, and the growth arrest-specific gene 6 protein (Gas6) ${ }^{10}$.

Except MGP, which has an internal recognition site for carboxylase, all Glaproteins characterized thus far are symthesized as preproproteins ${ }^{11}$. The presequence is required for translocation across the endoplasmic reticulum membrane, whereas the prosequence functions as a high affinity recognition site for carboxylase ${ }^{12,13}$. After carboxylation, the protein is transported through the cell to the trans Golgi network. There the propeptide is cleaved from the protein by a yet unknown proconvertase, after which the fully modified, mature Gla-protein is secreted into the circulation ${ }^{14}$. Therefore, circulating mature Gla-proteins lack the propeptide domain. Using in vitro carboxylating systems it was shown that small synthetic peptides lacking the propeptide (e.g. the pentapeptide FLEEL) are poor substrates with $K_{m}$ values in the millimolar range ${ }^{15.16}$. Under similar conditions, $K_{m}$ values for peptides that did contain the pro-sequence of either prothrombin or factor IX were 3-4 orders of magnitude lower "?. Also, the binding of pro-containing substrates lead to a $10-20$ fold decrease of the $K_{m}$ for the cofactor vitamin $K$ hydroquinone, suggesting an allosteric effect of the pro-domain upon binding to carboxylase ${ }^{18}$. Remarkably, the addition of free propeptide did not affect the $K_{m}$ for vitamin $K$ hydroquinone, and resulted in only a minor decrease $\left(<10\right.$-fold) of the $K_{m}$ 
for small peptide substrates ${ }^{19}$.

During recent years it has been shown that heat-decarboxylated bovine asteocalcin may serve as a substrate for bovine liver carboxylase ${ }^{11,20}$. The protein is exceptional because - despite its lack of a pro-domain - reported $K_{m}$ values are comparable with those of pro-containing substrates ${ }^{21,22}$. Because heat decarboxylation may cause unwanted and undefined damage to the protein molecule, we have prepared synthetic human osteocalcin, both in its carboxylated and non-carboxylated (descarboxy) form. The preparations will be designated here as $O C$ and $d-O C$, respectively. In this paper we have compared the substrate properties of d-OC with those of well-known other substrates for carboxylase, and we have tested the extent to which $O C$ is capable of inhibiting the carboxylation of various substrates. Finally we have investigated whether the low $K_{m}$ values for $d-O C$ are the result of an unusual high affinity of its Gla-domain for the carboxylase active site or, alternatively, of an internal docking sequence located elsewhere in the molecule. 


\section{Materials and Methods}

Reagents

All chemicals are of analytical grade or better. Vitamin $K_{\|}$(Konakion , mixed micelles) was purchased from Hoffmann-La Roche (Basel, Switzerland), $\mathrm{NaH}^{14} \mathrm{CO}_{3}$ with specific activity of $50 \mathrm{mCi} / \mathrm{mmol}$ was from New England Nuclear (Boston, MA) and CHAPS was from Sigma (St. Louis, MO). The insect cell expression vector (pVL1392) was purchased from Pharmingen (San Diego, CA) and the baculovirus viral DNA (BacVector 3000) was purchased from Novagen (Madison, WI). The Sf9 cells (Spodoptera frugiperda) were obtained from the Lineburger Cancer Center at the University of North Carolina-Chapel Hill, and the High Five cells (Trichoplusia ni) were a gift from Dr. Thomas Kost of Glaxo-Wellcome (Research Triangle Park, NC). The HPC4 antibody affinity resin was provided by Dr. Charles T. Esmon (Oklahoma Medical Research Foundation, Oklahoma City, OK). The FLAG antibody and FLAG peptide standards were purchased from Sigma (St. Louis, MO).

\section{Peptides}

$O C^{1-16}, O C^{13-25}, O C^{22-31}, O C^{29-43}, d-O C^{13-25}$ and $d-O C^{22-31}$ as well as Pro ${ }^{F I X}$ and Pro ${ }^{\circ 0}$ were synthesized by Pepscan Systems (Lelystad, The Netherlands). Both FLEEL and bEELOMe were purchased from Bachem (Bubendorf, Switzerland). Recombinant ProlX-59 Q/S was produced and purified as described previously ${ }^{17}$. ProPT(Glu) 10 and ProPT-28 F/A were synthesized by Perkin Elmer (Nieuwerkerk aan de IJssel, The Netherlands). The amino acid sequences of the various peptides are listed in table 1. 


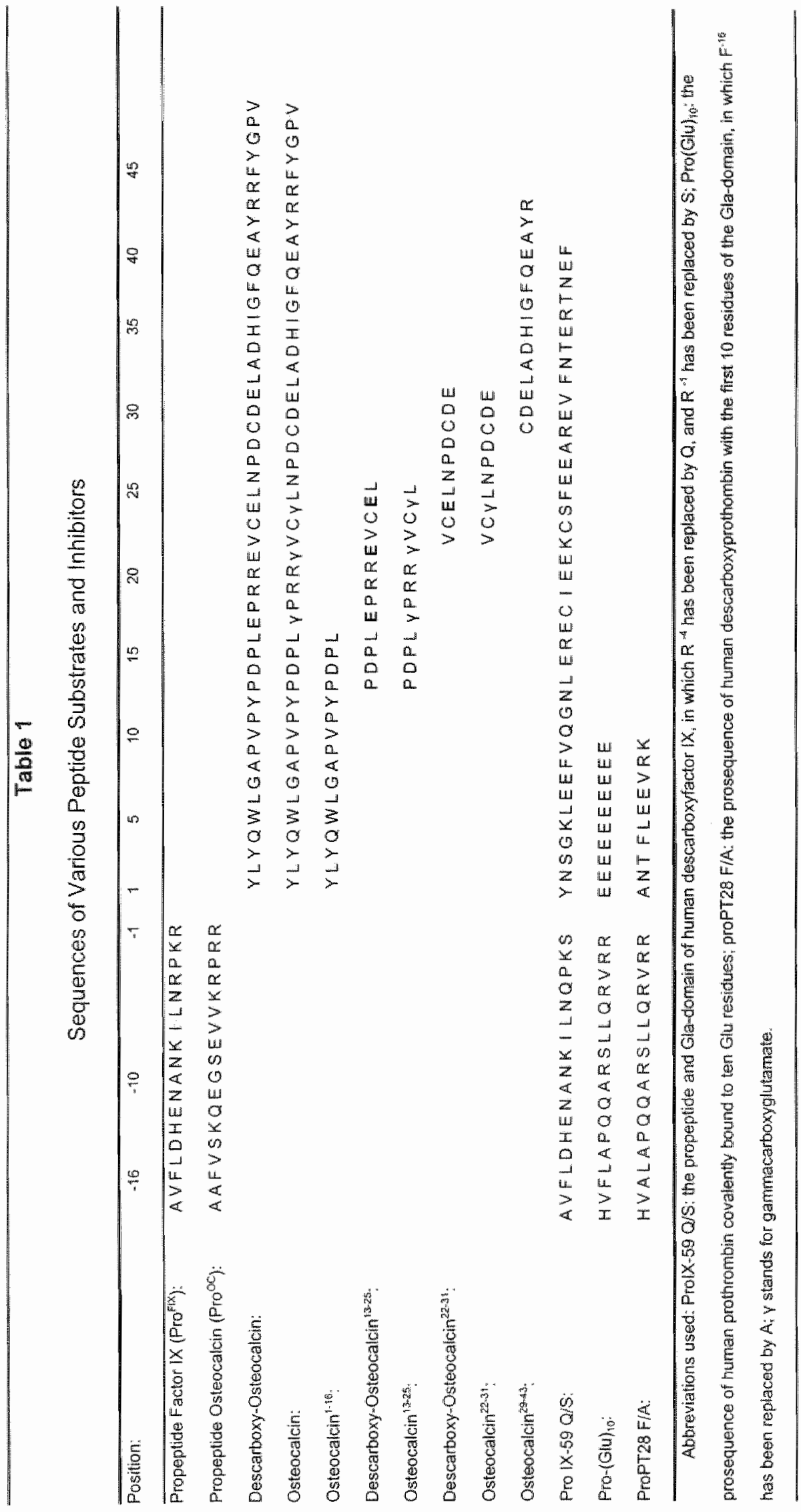


Synthesis of $O C$ and $d-O C$

Mature 49 amino acid osteocalcin (OC) and descarboxy-osteocalcin (d-OC) (table 1) were synthesized by solid-phase peptide synthesis using amino acids with Fmocprotected $\alpha$-amino groups on a 431A peptide synthesizer (Perkin Elmer, Foster City, CA) using standard FastMoc programs. The side chain protecting groups used were trityl for Asn, Cys, GIn and His, tert-butyl for Tyr, 2,2,5,7,8-pentamethyl-chroman-6sulfonyl for Arg and tert-butyl ester for Asp, Gla and Glu. All reagents and amino acids, except for the protected amino acid Gla (Bachem, Switzerland), were peptide synthesis grade from Perkin Elmer. After each coupling step, the free amino termini of non reacted peptides were capped by acetic anhydride to avoid elongation of incompletely synthesized peptides. To cleave the peptide from the resin and to remove the side-chain protecting groups, the resin bound protein was stirred for 90 min at room temperature in a cleavage mixture containing $0.75 \mathrm{~g}$ of crystalline phenol, $250 \mu$ lethanedithiol, $500 \mu$ thioanisole, $500 \mu$ bidistilled water and $10 \mathrm{ml}$ of trifluoroacetic acid. The peptide was separated from the resin by filtration through a medium-porosity glass filter and precipitated in cold methyl tert-butyl ether. The peptide was washed with methyl tert-butyl ether, dissolved in water and dried. The amino acid sequence of the synthetic proteins was confirmed by Edman degradation on a 477A/120A protein sequencer (Perkin Elmer, Foster City, CA).

\section{Mass spectrometry of $\mathrm{OC}$ and $d-\mathrm{OC}$}

To verify purity and the full carboxylation at positions 17,21 and 24 of the synthetic $O C$ and the purity of d-OC, electron spray ionization (ESI) mass spectrometry (MS) was performed on a Micromass Platform II (Micromass UK Ltd., Altrincham, Cheshire, UK) single quadrupole bench-top mass spectrometer operating in positive ionization mode. For the MS full scan spectra, data were acquired in continuum mode over the range $\mathrm{m} / \mathrm{z} 600$ to 3000 in 2 seconds at unit mass resolution. A cone voltage of $35 \mathrm{~V}$ was set, which produces predominantly $\mathrm{MH}^{+}$ions with little evidence of fragmentation for this type of peptides. Instrumental control, data acquisition and data processing were carried out using the MassLynx software package (version 
2.3). The observed average $\mathrm{m} / \mathrm{z}$ of $\mathrm{OC}$ of 5930.85 amu was compared with the calculated $\mathrm{MH}^{*}$ average mass of 5931.55 amu. Also the observed average $\mathrm{m} / \mathrm{z}$ of $\mathrm{d}$ $\mathrm{OC}$ of 5800.05 amu was compared with its calculated $\mathrm{MH}^{+}$average mass of 5799.45 amu. The calculated masses of both $\mathrm{OC}$ and $\mathrm{d}-\mathrm{OC}$ (with a free $\mathrm{N}$-terminus and a carboxyl group at the C-terminus) did not differ significantly from the measured masses and we therefore conclude (1) that the $\mathrm{OC}$ is pure and fully carboxylated and (II) that $d-O C$ is pure and not fragmented.

\section{Expression of r-carboxylase in Trichoplusia ni High-Five insect cells}

The cDNA encoding the human vitamin K-dependent carboxylase was sub-cloned into the EcoRI site of the pVL1392 vector. The sequence coding for the FLAG antibody epitope (DYKDDDDK) was introduced at the $\mathrm{N}$-terminal end of the carboxylase and a HPC4 antibody tag (EDQVDPRLIDGK) ${ }^{23}$ was added at the Cterminal end. The engineered vector was cotransfected with baculovirus BacVector 3000 triple cut virus DNA into Sf9 cells. Recombinant virus was isolated by plaque purification, amplified, and titered by plaque assay according to the manufacturer's instructions (Pharmingen, San Diego). Expression of carboxylase was done by infection of $-2 \times 10^{6} / \mathrm{ml}$ High Five Cells with the recombinant virus at a multiplicity of infection of $\sim 1$. Cells were collected after $48 \mathrm{~h}$ by centrifugation and stored at $-80^{\circ} \mathrm{C}$.

\section{Preparation of microsomes from High Five cells}

A total of $5 \times 10^{8}$ cells expressing the recombinant human carboxylase were washed with buffer $\mathrm{A}(25 \mathrm{mM}$ Tris-HCl, $\mathrm{pH} 7.4,150 \mathrm{mM} \mathrm{NaCl}$ and a protease inhibitor cocktail ${ }^{24}$ consisting of EDTA ( $2 \mathrm{mM}$ ), DTT ( $2 \mathrm{mM}$ ), Phe-Pro-Arg-chloromethyl ketone $(0.125 \mu \mathrm{g} / \mathrm{ml})$, Phe-Phe-Arg-chloromethyl ketone $(0.125 \mu \mathrm{g} / \mathrm{ml})$, leupeptin $(0.5$ $\mu \mathrm{g} / \mathrm{ml})$, pepstatin $(0.7 \mu \mathrm{g} / \mathrm{ml})$, PMSF $(34 \mu \mathrm{g} / \mathrm{ml})$, aprotinin $(2 \mu \mathrm{g} / \mathrm{ml})$ and $10 \%$ glycerol and resuspended in $50 \mathrm{ml}$ of buffer $\mathrm{A}$. The sample was homogenized by 5 strokes with a dounce homogenizer and then sonicated with twenty 5 second pulses and an interval time of 25 seconds using a Ultrasonic Heat Systems sonicator. Cellular debris was removed by centrifugation at $4000 \mathrm{~g}$ for $15 \mathrm{~min}$. The supernatant was 
then centrifuged at $105000 \mathrm{~g}$ for $1 \mathrm{hr}$. The microsomal pellet was resuspended in buffer $\mathrm{A}$ with a final protein concentration of $20 \mathrm{mg} / \mathrm{mll}, 1 \mathrm{x}$ protease inhibitor cocktail and $10 \%$ glycerol, aliquoted and stored at $-80^{\circ} \mathrm{C}$ until further use.

\section{Purification of r-carboxylase using HPC4 antibody resin}

Microsomes were diluted to a final protein concentration of $12 \mathrm{mg} / \mathrm{ml}$ and solubilized by the addition of an equal volume of solubilization buffer $(50 \mathrm{mM}$ TRIS pH 7.4, 0.15 $\mathrm{M} \mathrm{NaCl}, 1 \%$ CHAPS/ $0.2 \%$ phosphatidylcholine, $10 \%$ glycerol and $1 \mathrm{x}$ protease inhibitor cocktail) at $4^{\circ} \mathrm{C}$ for $1 \mathrm{hr}$. The solubilized microsomes were centrifuged at $105000 \mathrm{~g}$ for $1 \mathrm{hr}$ and the pellet was discarded. A total of $10 \mathrm{ml}$ of HPC4 resin was equilibrated with wash buffer (20 mM TRIS (pH 7.4), $150 \mathrm{mM} \mathrm{NaCl}, 0.5 \%$ CHAPSI0.2\% phosphatidylcholine, $1 \times$ protease inhibitor cocktail) and added to the solubilization supernatant allong with a final concentration of $5 \mathrm{mM} \mathrm{CaCl}$ and incubated overnight with gentle stirring. The resin was centrifuged and poured into a column, washed with $50 \mathrm{ml}$ of wash buffer plus $5 \mathrm{mM} \mathrm{CaCl}$ and eluted with wash buffer plus $10 \mathrm{mM}$ EDTA. Carboxylase samples were collected, aliquoted and stored at $-80^{\circ} \mathrm{C}$. Enzyme concentration was estimated from dot blots of carboxylase using the FLAG antibody and known concentrations of FLAG antibody standard.

\section{Carboxylase assay}

Standard reaction mixtures $(125 \mu \mathrm{l})$ contained : 6 nmol of HPC4 purified $\gamma$-glutamyl carboxylase, $25 \mathrm{mM}$ Tris-HCl pH 7.4, $150 \mathrm{mM} \mathrm{NaCl}, 0.2 \%$ CHAPS, $0.2 \%$ phosphatidyl choline, $5 \mu \mathrm{Ci} \mathrm{NaH}{ }^{14} \mathrm{CO}_{3}, 222 \mu \mathrm{M}$ of vitamin $\mathrm{K}$ hydroquinone $\left(\mathrm{KH}_{2}\right)$ and $5 \mathrm{mM} \mathrm{DTT}$. Substrates were added as indicated. The mixture was incubated at $20^{\circ} \mathrm{C}$ during 30 minutes in sealed tubes. Kinetic analysis was performed on subsamples drawn at $t=0, t=15$, and $t=30$ min. All reactions were stopped by adding $0.8 \mathrm{ml}$ of $5 \%$ trichloroacetic acid to $100 \mu$ li of reaction mixture and unbound ${ }^{14} \mathrm{CO}_{2}$ was removed by boiling for 3 minutes. After cooling down $5 \mathrm{ml}$ of Formula 989 (Packard Bioscience, Groningen, The Netherlands) was added. Finally samples were counted using a Wallac 1414 WinSpectral liquid scintillation counter (EG\&G Wallac, Turku, Finland). Data are expressed as pmol ${ }^{14} \mathrm{CO}_{2}$ incorporated per minute. 


\section{Results}

Kinetic constants for d-OC carboxylation

Kinetic constants of various osteocalcin-derived substrates were compared with other well known substrates for carboxylase (table 2). Substrates containing a propeptide sequence were characterized by $K_{m}$ values ranging between 0.4 and 5 $\mu M_{3}$, whereas the $K_{m}$ for pro-deficient peptides were in the millimolar range. $d-O C$, which lacks an $N$-terminal propeptide is an exception in this respect with a $K_{m}$ of 1.7 $\mu \mathrm{M}$. Remarkably, the corresponding peptide $\mathrm{d}-\mathrm{OC} \mathrm{C}^{13-25}$ was a poor substrate for carboxylase with a $K_{m} 3$ orders of magnituide higher than that for $d-O C_{n}$ similar to short peptide-substrates such as FLEEL. These experiments demonstrate that d-OC contains an internal recognition site for carboxylase enabling its efficient carboxylation. Since this recognition site was not present in $\mathrm{d}-\mathrm{OC} \mathrm{C}^{13-25}$ (containing the entire osteocalcin Gla-domain) it seems that a sequence outside its Gla-domain contributes to the recognition of mature osteocalcin by carboxylase. We have also tested $\mathrm{d}-\mathrm{OC}^{22-31}$ for its ability to serve as a substrate for carboxylase.

\section{Table 2}

Kinetic Constants for Different Peptide Substrates and the Cofactor $\mathrm{KH}_{2}$ During Carboxylation

\begin{tabular}{llcc}
\hline Substrate & $K_{\mathrm{m}} \pm \mathrm{SD}^{b}$ & $\begin{array}{c}\mathrm{V}_{\max } \pm \mathrm{SD}^{b} \\
\left(\rho \mathrm{mol}{ }^{* 4} \mathrm{CO}_{2}{ }^{*} \mathrm{hr}^{*}\right)\end{array}$ & $\begin{array}{c}\mathrm{K}_{\mathrm{m}} \text { for } \mathrm{KH}_{2} \pm \mathrm{SD}^{b} \\
(\mu \mathrm{M})\end{array}$ \\
\hline ProlX-59 Q/S & $0.51 \pm 0.09 \mu \mathrm{M}$ & $90 \pm 13$ & $5 \pm 0.5$ \\
ProPT-28 (F/A) & $5.35 \pm 0.77 \mu \mathrm{M}$ & $183 \pm 18$ & $3 \pm 0.4$ \\
Pro(Glu) & $0.56 \pm 0.18 \mu \mathrm{M}$ & $119 \pm 15$ & $9 \pm 1.1$ \\
d-OC & $1.71 \pm 0.35 \mu \mathrm{M}$ & $287 \pm 17$ & $13 \pm 0.9$ \\
d-OC & $9.1 \pm 2.05 \mathrm{mM}$ & $470 \pm 57$ & $61 \pm 3.4$ \\
BOC-EEL-OMe & $2.0 \pm 0.1 \mathrm{mM}$ & $182 \pm 11$ & $39 \pm 2.3$ \\
FLEEL & $2.4 \pm 0.2 \mathrm{mM}$ & $401 \pm 32$ & $34 \pm 1.7$ \\
\hline
\end{tabular}

\footnotetext{
Reactions were performed as detailed under Experimental procedures. Kinelfic parameters were determinad by fituting the data to the Michaelis -Menten equation.

A Values are means \pm standard dewation, obtained from at least 3 independent determinations.
} 
However, this peptide was not measurably carboxylated, nor was carboxylation observed when $\mathrm{OC}^{1-16}$ was added (data not shown). It has been shown previously that for the carboxylation of short peptide substrates the $\mathrm{K}_{\mathrm{m}}$ for $\mathrm{KH}_{2}$ is relatively high, but that it is substantially decreased upon binding of propeptide-containing substrates ${ }^{1:}$. The data in table 2 show that in this respect $\mathrm{d}-\mathrm{OC}$ only partly mimics the propeptide-containing substrates, with a $\mathrm{K}_{\mathrm{m}}$ for $\mathrm{KH}_{2}$ which is 4 times higher than that in the case of ProlX-59 Q/S carboxylation, but almost 5 times lower than that of $\mathrm{d}-O \mathrm{C}^{13-25}$ carboxylation.

\section{Inhibitory effect of OC on d-OC and bEELOMe carboxylation}

Because of the high degree of sequence homology of $\mathrm{d}-\mathrm{OC}$ and $\mathrm{OC}$, it seemed at least feasible that both moleculles have affinity for carboxylase. In that case OC would be expected to act as an inhibitor of d-OC carboxylation.

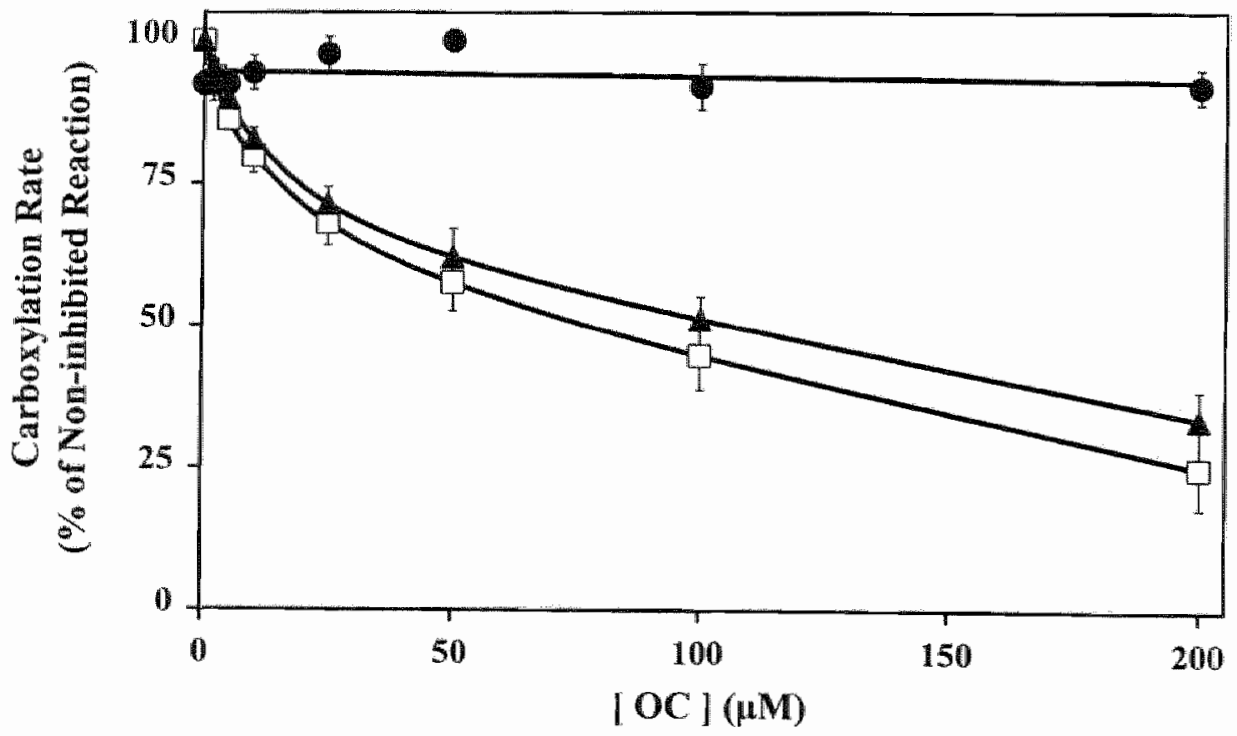

Figure 1: Effect of $\mathrm{OC}$ on the carboxylation of different substrates. All incubations were at $20{ }^{\circ} \mathrm{C}$ for $30 \mathrm{~min}$. All values are means from at least three independent measurements, andi are expressed as a percentage of the non-inhibited reaction rate. Explanation of

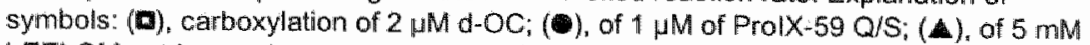
bEELOMle at increasing amounts of OC. If error bars are not visible they lie within the size of the symbol used. 
Therefore, we have investigated the potential inhibitory effect of OC on the carboxylation of various substrates. As is shown in figure 1, the carbaxylation of 1 $\mu \mathrm{M}$ of the propeptide-containing ProlX-59 Q/S was not inhibited, even at 200 fold molar excess of $O C$. d-OC carboxylation was inhibited with a $K_{i}$ of $76 \mu \mathrm{M}$ (about 45 times the $K_{m}$ for $d-O C$ ), and bEELOMe with a $K_{i}$ of $104 \mu M$ (about 0.05 times the $K_{m}$ for bEELOMe). These results show that $O C$ is not an inhibitor for propeptidecontaining substrates, whereas it inhibits propeptide-deficient substrates with high and low sequence homology to a similar extent. In an attempt to locate more precisely the sequence responsible for the high affinity of d-OC for carboxylase, we have tested the potential inhibitory effects of a number of peptides derived from $O C$ : $O C^{1-46}, O C^{13-25}, O C^{22-31}$, and $O^{29-43}$. However, neither alone nor in combination any of these peptides inhibited $d-O C$ carboxylation.

\section{Effect of free propeptides on d-OC and ProlX-59 Q/S carboxylation}

As was previously shown ${ }^{25}$, the presence of free propeptide stimulates in vitro substrate carboxylation by lowering the $\mathrm{K}_{\mathrm{m}}$ for substrates derived from blood clotting factors. We have investigated whether propeptides have a similar effect on substrates derived from osteocalcin. Also, we have tested to what extent free propeptides may act as competitive inhibitors for pro-containing substrates during substrate recognition by carboxylase. Propeptides used for these studies were those derived from human factor $I X\left(\mathrm{PrO}^{\mathrm{FIX}}\right)$ and human osteocalcin $\left(\mathrm{PrO}^{\circ \mathrm{C}}\right)$, and we have measured the effects of these propeptides on the carboxylation of four different substrates. The data shown in table 3 were obtained in the presence of either $20 \mu \mathrm{M}$ Pro $^{F I X}$ or $20 \mu \mathrm{MPro}^{\circ \mathrm{C}}$ and demonstrate that Pro ${ }^{\mathrm{FIX}}$ acted as an inhibitor for the procontaining ProlX-59 Q/S, and that it mildly stimulated the propeptide-deficient bEELOMe. Its effects on osteocalcin-derived substrates were negligible. In contrast, Pro ${ }^{\circ C}$ did not affect the carboxylation of either substrate. At increasing Profix concentrations, a dose-dependent inhibition with a $K_{1}$ of $0.8 \mu$ M of ProlX-59 Q/S was observed (fig. 2), whereas even at $200 \mu \mathrm{M}$ of Pro ${ }^{\mathrm{FIX}}$ the carboxylation of $\mathrm{d}-\mathrm{OC}$ remained unaffected. On the other hand, Pro ${ }^{\circ C}$ did not inhibit either substrate even 
at very high concentrations. In our opinion it seems unlikely that an attached propeptide lowers the $K_{m}$ for osteocalcin even further. Data reported by Benton et all. sthowed only a 3-fold difference between propeptide- lacking and propeptidecontaining descarboxy osteocalcin $10.72 \mu \mathrm{M}$ versus $0.24 \mu \mathrm{M}$ respectively) Comparison of these data with ours is hampered by the fact that the authors have studied the kinetic parameters in purified bovine carboxylase which contained 100 uM of free human factor $X$ propeptide.

\section{Table 3}

Effect of Propeptides on $K_{m}$ ap for Various Substrates in the Vitamin K-Dependent Carboxylation Reaction

\begin{tabular}{|c|c|c|c|}
\hline Substrate & $\begin{array}{l}\mathrm{K}_{\mathrm{m}} \pm \mathrm{SD}^{\mathrm{b}} \\
\text { No Addition }\end{array}$ & $\begin{aligned} & K_{\mathrm{vorib}} \pm S D^{6} \\
+ & 20 \mu \mathrm{MPro}\end{aligned}$ & $\begin{aligned} & \mathrm{K}_{\mathrm{m}} \pm \mathrm{SD}^{\circ} \\
+ & 20 \mu \mathrm{M} \mathrm{Pro}^{\circ}\end{aligned}$ \\
\hline $\mathrm{d} \cdot \mathrm{OC}$ & $1.7 \pm 0.35 \mu \mathrm{M}$ & $1.9 \pm 0.24 \mu \mathrm{M}$ & $1.8 \pm 0.37 \mu \mathrm{M}$ \\
\hline$d-O C^{13-25}$ & $9.1 \pm 2.05 \mathrm{mM}$ & $4 \pm 0.90 \mathrm{mM}$ & $10 \pm 1.90 \mathrm{mM}$ \\
\hline PrallX.59 Q/S & $0.5 \pm 0.10 \mu \mathrm{MM}$ & $2.6 \pm 0.35 \mu \mathrm{M}$ & $0.4 \pm 0.26 \mu \mathrm{M}$ \\
\hline bEELOMe & $2.1 \pm 0.10 \mathrm{mM}$ & $0.6 \pm 0.40 \mathrm{mM}$ & $2.2 \pm 0.80 \mathrm{~mm}$ \\
\hline
\end{tabular}

Reactions were perfomed as detaled under Experimental procedures. Kinetic parameters were determined by fitting the data to the Michaelis - Menten equation.

b. Values are means \pm standard deviation, obtained from at least 3 independent determinations.

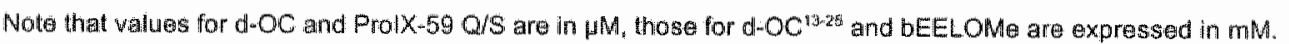

For aboreviations see llegend to table 1.

From these data we conclude (1) that the affinity of carboxylase for Pro ${ }^{\circ C}$ must be substantially lower than that of Pro ${ }^{F 1}$, and (II) that carboxylase must have a high affinity site for $\mathrm{d}-\mathrm{OC}$ which differs from the propeptide recognition site. 


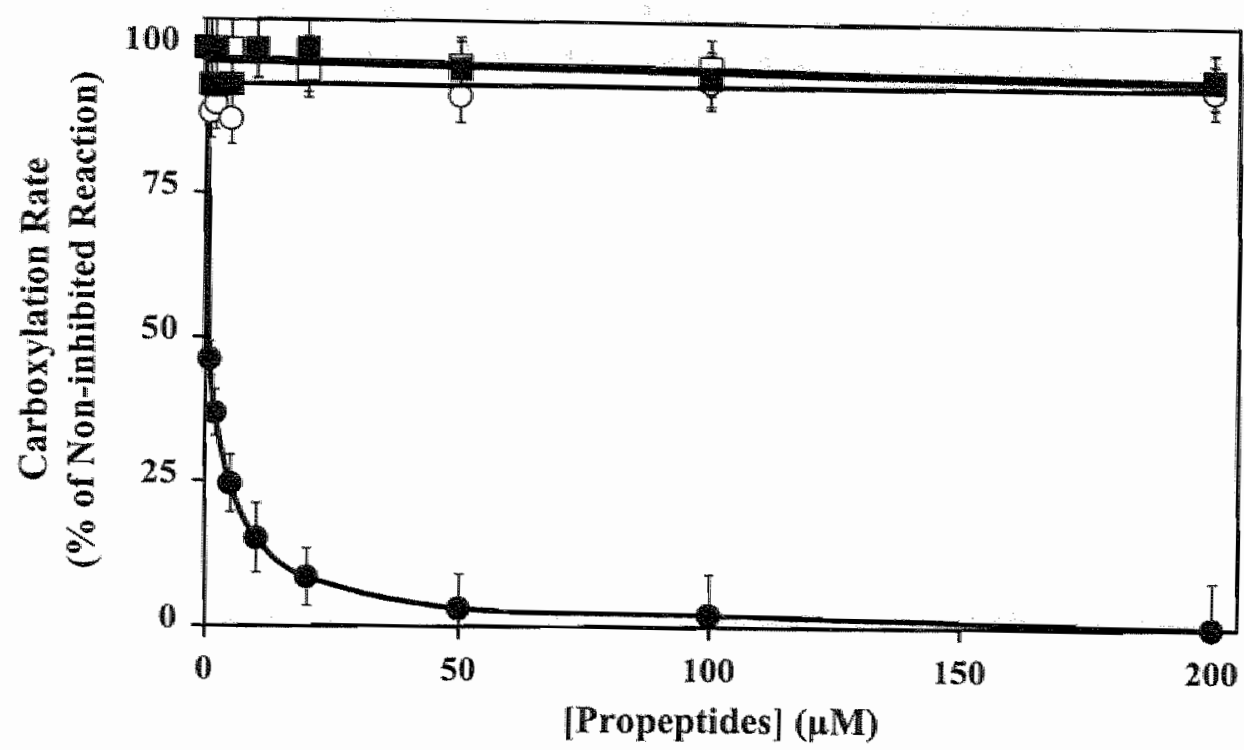

Filgure 2: $\quad$ Effect of propeptides on substrate carboxylation. The carboxylation of $1 \mu M$ ProlX-59 Q'S was measured at various concentrations of either $\operatorname{Pro}^{F \mid X}(0)$ or $\operatorname{Pro}^{\circ C}(a)$, the carboxylation of $2 \mu \mathrm{M}$ of $\mathrm{d}-\mathrm{OC}$ was measured at various concentrations of either Pro $^{\mathrm{FIX}}$ ( or Pro ${ }^{\circ \mathrm{CC}}$ ( $\mathrm{C}$ ). Incubations were performed at $20{ }^{\circ} \mathrm{C}$ for $30 \mathrm{~min}$. All values are means from at least three independent measurements, and are expressed as a percentage of the non-inhibited reaction rate.

\section{Discussion}

Decarboxylated bovine osteocaicin has been reported to serve as a substrate for crude microsomal carboxylase ${ }^{11,20,20}$ as well as for affinity-purified carboxylase ${ }^{27}$. Although osteocalcin lacks an $\mathrm{N}$-terminal propeptide, reported $\mathrm{K}_{\mathrm{m}}$ values were in the micromolar range, which is characteristic for substrates containing the pro-sequence. Whereas bovine liver microsomal carboxylase may be contaminated with procontaining endogenous substrates, the affinity-purified enzyme is saturated with free propeptide as a consequence of its elution from the affinity ligand. Neither of these systems is suitable for determining the kinetic constants for osteocalcin carboxylation, and the effects thereon of various propeptides. Therefore, we used purified recombinant human carboxylase expressed in insect cells known to be free of endogenous precursor proteins. Carboxylase was eluted from the affinity column 
in the absence of free propeptide, thereby generating carboxylase completely devoid of interfering pro-containing proteins. Synthetic osteocalcin and derived peptides were the substrates of choice in this system rather than thermally decarboxylated natural osteocalcin, because the heat treatment may induce structural changes or (partial) degradation.

Using this system we have demonstrated for the first time that, in the absence of propeptide, $\mathrm{d}-\mathrm{OC}$ is a good substrate for carboxylase, with a $\mathrm{K}_{\mathrm{m}}$ of $1.7 \mu \mathrm{M}$. This is in the range of substrates containing the pro-sequence $(0.5-5.3 \mu \mathrm{M})$, and widely different from substrates lacking a pro-sequence $(2-9 \mathrm{mM})$. The question remains which structural determinants of osteocalcin contribute to its recognition by carboxylase. It was shown that $O C$ acts as an inhibitor of $d-O C$ carboxylation, suggesting that elements of recognition are shared by both substrate and product. Shorter sequences in- or outside the Gla-domain were either (in their noncarboxylated form) poor substrates for carboxylase, or (in their carboxylated form) not inhibitors of d-OC carboxylation. Moreover, $O C$ failed to inhibit pro-containing substrates such as ProlX-59 Q/S. Competitive inhibition by free propeptide was demonstrated between Pro ${ }^{1 \mathrm{X}}$ and ProlX-59 Q/S, but neither Pro ${ }^{1 \mathrm{x}}$ nor Pro ${ }^{\circ \mathrm{C}}$ inhibited d-OC carboxylation. The fact that Pro ${ }^{\circ}$ did not inhibit ProlX-59 Q/S carboxylation is consistent with its reported low affinity for carboxylase ${ }^{28}$. Our data suggest that at least two different docking sites are located on carboxylase: one for pro-containing substrates, and a second one for d-OC. Whereas there seems to be no clear role in enzyme-substrate recognition for the pro-sequence in osteocalcin precursor proteins, osteocalcin itself may contain an internal recognition site for carboxylase. This is also seen in matrix Gla-protein (MGP), another Gla-protein synthesized in bone. Because osteocalcin and MGP have significant sequence similarity, it has been suggested that both proteins have developed from a common ancestor protein ${ }^{20,30}$. However no sequence homology between the internal propeptide of MGP and mature osteocalcin is seen and therefore we suggest the presence of a different binding site on carboxylase.

Besides serving as an element of recognition for the docking site on carboxylase, it has been previously shown that the pro-sequence in pro-containing substrates possess the remarkable property of decreasing the $\mathrm{K}_{\mathrm{m}}$ for $\mathrm{KH}_{2}$ by $10-20$ 
fold ${ }^{\text {if }}$. An explanation for this phenomenon may be found in postulating an allosteric conformational change of carboxylase upon binding of the pro-sequence. This effect is also evident from table 2 , with $\mathrm{K}_{\mathrm{m}}$ values for $\mathrm{KH}_{2}$ ranging from $3-9 \mu \mathrm{M}$ for carboxylation of pro-containing substrates, and from 34-61 $\mu \mathrm{M}$ for carboxylation of short peptides. The $\mathrm{K}_{\mathrm{m}}$ of $13 \mu \mathrm{M}$ for $\mathrm{KH}_{2}$ at d-OC carboxylation is close to the range observed for carboxylation of pro-containing substrates, and demonstrates that the presence of the pro-sequence is not an absolute requirement to increase the affinity between carboxylase and its cofactor $\mathrm{KH}_{2}$. It cannot be excluded at this time that the pro-sequence in osteocalcin precursors is to induce a more pronounced interaction between carboxylase and $\mathrm{KH}_{2}$ thus lowering the $\mathrm{K}_{\mathrm{m}}$ for $\mathrm{KH}_{2}$ to the same values as those observed for the other pro-containing substrates. Definite proof of this hypothesis might be obtained from a pro-sequence containing osteocalcin molecule. However, the long-chain synthesis by Fmoc chemistry with high efficiency is limited to about 50 residues in our hands. Only a few successful long-chain syntheses have been reported uptill now using the linear Fmoc protocol ${ }^{3-34}$, indicating the problems accompanying the synthesis of these long peptide chains ( $>50$ residues).

In conclusion, we have demonstrated that descarboxy-osteocalcin binds with high affinity to carboxylase, and that the osteocalcin pro-sequence does not play a noticeable role in the enzyme-substrate interaction. Moreover, the data presented strongly suggest the presence of two substrate docking sites on carboxylase: one recognizing the pro-sequence in clotting factor-type substrates, and a second one with high affinity for osteocalcin precursors.

\section{Acknowledgments}

Dr. Paul Proost is a senior research assistant of the Fund for Scientific Research (FWO-Vlaanderen).

The authors wish to thank Dr. Dirk T.S. Rijkers (Department of Medicinal Chemistry, Institute for Pharmaceutical Sciences, Utrecht University, the Netherlands) for providing the data of the electron spray mass determination of synthetic osteocalcin. 


\section{References}

1. Hasuschka, P. V. Haroon, Y., Buchtial, S. D. 2 Bell, R. G. Vitamin K-dependent processes in tumor cetls. Haenostasis 16, 273-87 (1986).

2. Wolf G. Function of the bone protein osteocalcin: definitive evidence. Nutr Rev 54, 332-333 (1996).

3. Price, P. A. Role of vitamin-Koptependent proteins in bone metabolism. Amnu Rev Nutr B, 565-583 $(1986)$

4. Hauschka, P. V. Lian, J. B., Cole, D. E. \& Gundberg, C. M. Osteocalcin and matrix Gla protein: vitamin K-clependent proteins in bone. Physiol Rew 69, 990-1047 (1989).

5. Furie, B. C. F Furie, B. Structure and mechanism of action of the vitamin Kudependent gammaglutamyl carboxylase: recent advances from mutagenesis studies. Thromb Haemost 78, 595-598 $(1997)$.

6. Wu, S. M., Morris, D. P. \& Stafford, D. W. Identification and purification to near homogeneity of the vitamin Kudependent carboxylase. Proc Natl Acad Sci USA 88, 2236-2240 (1991).

7. Vermeer, $\mathbb{C}$, Gamma-carboxyglutamate-containing proteins and the witamin K-dependent carboxylase. Biochem \& 266, 625-636 (1990).

8. Fraser, 4. D. \& Price, P. A. Lung, heart, and kidney express high levels of mRNA for the vitamin Kdependent matrix Gla protain. Implications for the possible functions of matrix Gla protein and for the tissue distribution of the gamma-carboxylase. J Biol Chem 263, 11033-11036 (1988).

9. Luo, G. et al. Spontaneous calcification of arteries and cartilage in mice lacking maltix GLA protein. Nature 385, $78-81$ (1997).

"10. Nakano, T. et al. Requirement of gamma-carboxyglutamic acid residues for the biological activity of Gas6: contribution of endogenous Gas6 to the proliferation of vascular mooth muscle cells Biochen $1323,387-392(1997)$.

11. Engleke, J. A., Halle, J. E., Suttie, J. W. \& Price, P. A. Vitamin K-dependent carboxylase: utilization of decarboxylated bone Gla protein and matrix Gla protein as substrates. Biochim Biophys Acta 1078, 31-34 (1991).

12. Jorgensen, M. J. tat al. Recoghithon site directing vitamin K-dependent gamma-carboxylation resides on the propeptide of factor IX. Cel 48, 185-191(1987).

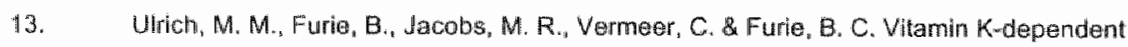
carboxylation. A synthetic peptide based upon the gamma-carboxylation recognition site sequence of the prothrombin propeptide is an active substrate for the carboxylase in witro. J Biol Chem 263, 969\%. 9702 (1988).

14. Furie, B., Bouchard, B. A. \& Furio, B. C. Vitamin K-Dependent Biosynthesis of gammaCarboxyglutamic Acid. Blood 93, 1798-1808 (1999).

15. Suttia, J. W., Lahrman, S. R., Geweke, L. O., Hageman, ע. M. \& Rich, D. H. Wtamin K-dependent carboxylase: requirements for carboxylation of soluble peptide and substrate specificity. Biochem Biophys Res Commun 86, 500-507 (1979).

16. Suttie, J. W. \& Jackson, C. M. Prothrombin structure, activalion, and biosynthesis. Physiol Rev 57 , 1$70(1977)$.

17. Wu, S. M., Soute, B. A., Verneer, C. \& Stafford, D. W. In vitro gamma-carboxylation of a 59-residue 
recombinant peptide including the propeptide and the gamma-carboxyghtamic acid diomaim of coagulation factor $\mathrm{X}$. Efrect of mutations near the propeptide cleavage sitte. J Biof Chem 265, 13124 $13129(1990)$.

18. Soute, B. A. ef al. Congenital deficiency of all vitamin K-dependent blood coagulation factors due to a defective vitamin K-dependent carboxylase in Devon Rex cats. Thromb Haemost 68; 521-525 (1992).

19. Cheung. A., Engelke, J. A., Sanders, C. \& Suttie, J. W. Whamin K-dependent caboxylase: influence of the "propeptide" region on enzyme activity. Arch Giochem Biophys 274, 574-581 (1989).

20. Benton, M. E. Price, P. A. \& Suttie, J. W. Multi-site-specificity of the witamin K-dependert! carboxylase: in vitro carboxylation of des gamma-carboxylated bone Gla protein and Des-gammacarboxylated pro bone Gla protein. Biochemistry 34, 9541-9551 (1995).

21. Uirich, M. M., Soute, B. A. de Boer van den Berg, M. A. \&ermeer, C. Isoenzymes of vitamin-K. dependent carboxylase. Biochim Blophys Acta 830, 105-108 (1985).

22. Van Haatlem. L. J., Uirich, M. M., Hemker, H. C., Soute, B. A. \& Vameer , C. Isolation and partial characterization of a vitamin Kodependent carboxylase from bovine aortae. Blochen $/ 245,251-255$ (1987).

23. Steams, D. J. Kurosawa, S., Sims, P. J. Esmon, N. L. \& Esmon, C. T. The interaction of a Ca2t. dependent monoclonal antibody with the protein $\mathrm{C}$ activation peptide region. Evidence for obtigatary Ca2+binding to both antigen and antibody. J Biof Chem 263, 826-832 (1988).

24. Wu, S. M., Mutucumarana, V.P. \& Stafford, D. W. Punitication of gamma-glutamyl carboxylase from bowne liwer. Methods Enzymol 282, 346-357 (1997).

25. Knoblach, J. E. Suttie, J. W. Vitamin K-dependent carboxylase. Contral of enzyme activity by the "propeptide" region of factor $X$.J Biol Chem 262, 15334-15337 (1987).

26. Vermeer, C., Soute, B. A., Hendrix, H. \& de Bider van den Berg, M. A. Decarboxylated bone Glaprotoin as a substrate for hepatic vitamin K-dependent carboxylase. FEBS Lett 165, 16-20 (9984).

27. Benton. M. E. \& Suttie, J. W. Determimation of site-specific gamma-carboxyglutamic acid formation by vitamin K-dependent carboxylase utilizing De-gamma-camboxy bone Gla protein as substrate. Methods Enzymol 282, 384-395 (1997).

28. Stanley, T. B., Jin, D. Y., Lin, P. J. \& Stafford, D. W. The propeptides of the vitatin K-dependent proteins possess different aftinities for the vitamin Kadependent carboxylase. J Bor Chem 274, 16940$16944(1999)$

29. Price, P. A. Willamyson, M. K. Primary structure of bovine matrix Gla protein, a new witarnin K. dependent bone protein. J Bio Chen $260,1497 \%-14975$ (1985).

30. Young. M. F., Ker, J. M. Ibaraki, K. Heegaard, A. M. \& Robey, P. G. Structure, expresgion, and regulation of the major noncollagenous matrix proteins of bone. Clin Orthop 281, 275-294 (1992).

31. Wu, C.AR., Stevens, V. C. Tregear, G. W. \& Wade, J. D. Conthuous flow solid-phase syrthesis of a 74-peptide fragment analogue of human beta-chorionic gonadotropin. J Chem Soc Porkin Trans 1 , 81. $87(1989)$.

32. Ramage, R. Green, J. \& Ogunjobi, O. M. Solid phase peptide synthesis of ubiquilin. Tetrahedron Lett. $28,2949-2152(1989)$.

33. Qgunjobt, 0. \& Ramage. R. Ubiquitin preparative chemical synthesis, purficallon and 
characterization. Biochem Soc Trans 18, 1322-3 (1990).

34. Chun, R, Glabe, C. G. \& Fan, H. Chemicat synthesis of biologically active tat trans-activating protein of human immunodeficiency virus type 1. J Virol 64, 3074-3077 (1990). 


\section{Chapter 5}

\section{OSTEOCALCIN SPECIFIC BINDING SITE ON THE VITAMIN K-DEPENDENT GAMMA-GLUTAMYL CARBOXYLASE}

Roger J.T.J. Houben ${ }^{\ddagger}$, Thomas B. Stanley ${ }^{\$}$, Robert Azerad", Cees Vermeer ${ }^{*}$ and Berry A.M. Soute ${ }^{*}$,

* Department of Biochemistry and Cardiovascular Research Institute, Maastricht University, The Netherlands; "Department of Biology, University of North Carolina, Chapel Hill, USA and "Laboratory of Pharmacological and Toxicological Chemistry and Biochemistry (URA 400 CNRS). Universite R. Descartes, Paris, France.

Based on: Biochemical loumal submitted 


\section{Abstract}

Two different sites on vitamin K-dependent carboxylase are involved in enzymesubstrate interaction: the propeptide binding site required for high affinity substrate binding, and the active site for glutamate carboxylation. Synthetic descarboxyosteocalcin is a low $K_{m}$ substrate for the vitamin $K$-dependent $\mathrm{V}$-glutamyll carboxylase, but unique since it does not make use of the propeptide binding site on $y$-glutamylcarboxylase. With the aid of a stereospecific substrate analog we have demonstrated that the high affinity of descarboxy-osteocalcin for carboxylase can neither be explained by a direct interaction with the active site nor with the propeptide binding site on carboxylase. On the basis of these data we postulate the presence of a second high affinity substrate binding site on $\gamma$-glutamylcarboxylase capable of specifically binding descarboxy-osteocalcin. 


\section{Introduction}

In wivo, all known proteins containing $y$-carboxyglutamic acid (Gla) residues are synthesized in a precursor form ' in which a propeptide sequence preceding the Gla domain serves as a high affinity recognition site for the vitamin K-dependent $Y^{\text {- }}$ glutamyl carboxylase ${ }^{2-4}$. This concept implies that at least two seperate sites on carboxylase must be involved in substrate interaction: a docking site for substrate recognition and binding, as well as the active site at which glutamic acid (Glu) residues are converted into Gla residues?

Small synthetic Glu-containing peptides lacking this propeptide sequence (e.g. PheLeu-Glu-Glu-Leu; FLEEL) do not bind to the docking site but diffuse directly into the active site and are poor substrates with $K_{m}$ values in the millimolar range ${ }^{5,6}$. The twosite model for carboxylase turned out to be insufficient describing all enzymesubstrate interactions because descarboxy-osteocalcin ( $d-O C$ ) binds to carboxylase with high affinity without the requirement of a pro-sequence. In previous experiments we have shown that $\mathrm{d}-\mathrm{OC}$ does not bind to the propeptide binding site on carboxylase, and that its propeptide does not contribute to the binding of $\mathrm{d}-\mathrm{OC}$ to carboxylase. Based on these observations we have postulated a second substrate docking site on carboxylase ${ }^{7}$. It could not be excluded, however, that the active site itself functions as the high affinity docking site for $\mathrm{d}-\mathrm{OC}$.

To further investigate this potential osteocalcin binding site on carboxylase we have compared the kinetic characteristics of a tripeptide substrate, a pro-containing substrate and $\mathrm{d}$ OC in the absence and presence of the methylated tripeptide (SMeTPT), a stereospecific substrate analog, acting as an active site inhibitor ${ }^{2}$. 


\section{Materials and Methods}

Reagents

All chemicals were of analytical grade or better. Vitamin $K_{1}$ (Konakion, mixedmicelles) was purchased from Hoffmann - La Roche (Basel, Switzerland), $\mathrm{NaH}^{14} \mathrm{CO}_{3}$ with a specific activity of $50 \mathrm{mCi} / \mathrm{mmol}$ was from NEN (Boston, MA) and CHAPS $\{3$ [(3-cholamidopropy $)$ dimethylammonio]-1-propane sulfonate was from Sigma (St. Louis, MO).

\section{Peptides and proteins}

d-OC was synthesized by Dr. P Proost (The Regla Institute, Dept. of Molecular Immunology, Catholic University of Leuven, Belgium), according to Wuyts et. al. " and a kind gift of Dr. R.H.M. Ebberink (Perkin - Elmer Netherlands Ltd, Nieuwerkerk aan de IJssel, The Netherlands). The tripeptide boc-Glu-Glu-Leu-O-Me (bEELOMe) was from Bachem (Bubendorf, Switzerland). Boc-(2S,4S)-4-methylglutamic acid was synthesized according to Righini-Tapie and Azerad ${ }^{\text {to }}$, and incorporated into Boc$(2 S, 4 S)-4-M e G l u-G l u-V a l-(S-M e T P T)$ via a sequential method using selectively protected $\gamma$-benzyll, $\alpha$-N-hydroxysuccinimide esters ${ }^{11.12}$. ProlX-59 Q/S, a 59 amino acid peptide containing the human factor $\mid X$ propeptide and the first 41 residues of factor IX Gla domain (sequence -18 to 41 ) with an Arg to Gin mutation at the -4 position and an Arg to Ser mutation at position -1 was produced and purified as described previously ${ }^{4}$. The propeptides (sequence -18 to -1 ) of both the human precursor molecules of osteocalcin (Pro $\left.{ }^{\circ c}\right)$ and blood coagulation factor $\mathrm{X}\left(\mathrm{P} r \mathrm{O}^{\mathrm{Fx}}\right.$ ) were purchased from Pepscan Systems (Lelystad, The Netherlands)

\section{Carboxylase assay}

Expression of r-carboxylase in Trichoplusia ni High-Five insect cells the preparation of microsomes and the purification of r-carboxylase using HPC4 antibody resin was performed as described ${ }^{7}$. Standard reaction mixtures were used as described ${ }^{7} ; 25$ nmol of HPC4 purified y-glutamyl carboxylase was used.Kinetic parameters were determined by fitting to the Michaelis-Menten equation for tinear regression ${ }^{13}$. 


\section{Results}

\section{Propeptide binding site inhibition}

First, we have examined the importance of the propeptide sequence in substrate recognition by testing the effect of free factor $\mathrm{IX}$ propeptide (Pro ${ }^{\mathrm{FiX}}$ ) on the carboxylation of recombinant ProlX-59 Q/S. As was reported previously, ProlX-59 Q/S has a high affinity for carboxylase which makes it an efficient substrate for in vitro vitamin K-dependent $\gamma$-carboxylation ${ }^{4}$. As shown in figure 1a, ProlX-59 Q/S carboxylation is competitively inhibited by $P$ ro ${ }^{F I X}$ with a $K_{i}$ of $0.97 \pm 0.19 \mu \mathrm{M}$, which is consistent with binding of substrate and inhibitor at the same site on carboxylase. These data also suggest an initial interaction of the propeptide sequence with the carboxylase propeptide binding site rather than with the active site.

\section{Active site inhibition}

The kinetic characteristics of active site inhibition by S-MeTPT were assessed using the homologous tripeptide substrate bEELOMe. This small substrate lacks a propeptide sequence and, therefore, has a $K_{m}$ in the millimolar range. S-MeTPT is known to be an effective active site inhibitor and, as shown in figure $1 \mathrm{~b}$, the carboxylation of bEELOMe is competitively inhibited. These data illustrate that both inhibitor and substrate act directly on the active site of carboxylase. In contrast, the inhibition of the ProlX-59 Q/S carboxylation by S-MeTPT was found to be noncompetitive (figure 1c). The non-competitive nature of the active site inhibition is consistent with a critical role for the propeptide binding site, rather than for the active site, during the formation of the enzyme-substrate complex.

Finally, we have examined the inhibition of d-OC carboxylation by S-MeTPT (figure 1d) and it was found that also $d-O C$ was non-competitively inhibited.

The various kinetic characteristics are summarized in table 1. 


\section{Table 1}

Kinetic Parameters for ${ }^{14} \mathrm{CO}_{2}$ Incorporation for bEELOMe, ProlX-59 Q/S and $\mathrm{d}-\mathrm{OC}$ in the Absence or Presence of S-MeTPT

\begin{tabular}{|c|c|c|c|}
\hline & $K_{m} \pm S D^{(b)}$ & $V_{\text {max }} \pm S D^{(b)}$ & $K_{i} \pm S D^{K(C)}$ \\
\hline Substrate & & & (pmol ${ }^{14} \mathrm{CO}_{2}$ incorporation ${ }^{*}$ min $^{-1}$ ) \\
\hline DEELOME & $1.20 \pm 0.3 \mathrm{mM}$ & $20.4 \pm 1.05$ & $289 \pm 35 \mu M$ \\
\hline Prolx-59 Q/S & $0.15 \pm 0.09 \mu \mathrm{M}$ & $3.3 \pm 0.15$ & $493 \pm 66 \mu \mathrm{M}$ \\
\hline $\mathrm{d}-\mathrm{OC}$ & $2.58 \pm 0.74 \mu M$ & $23.7 \pm 1.44$ & $491 \pm 30 \mu M$ \\
\hline
\end{tabular}

(a) Reactions were performed as detailed in methods using 4 concentrattons of each substrate in absence of inhibitor. ${ }^{(b)}$ Values are \pm standard deviation, obtained from at least three independent determinations in absence of inhibitor, ${ }^{\text {(ei }}$ Values are \pm standard dewiation, obtained from at least three independent determinations in presence of inhibitor. 
Fig. $1 \mathrm{~A}$

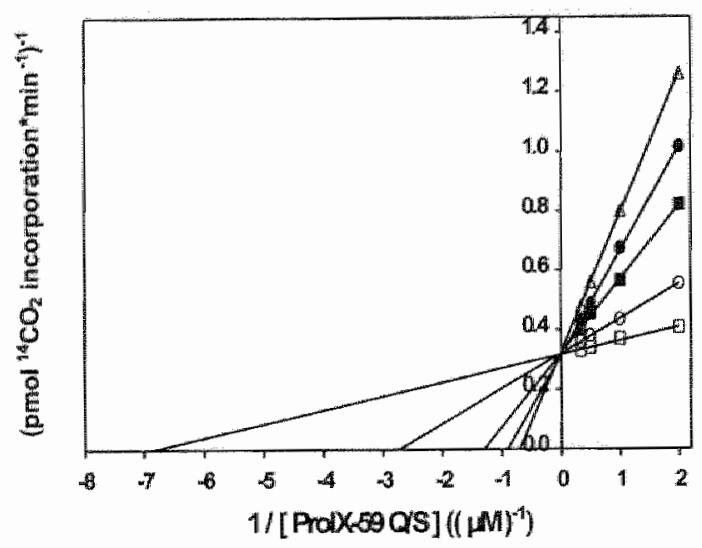

Fig. $1 \mathrm{C}$

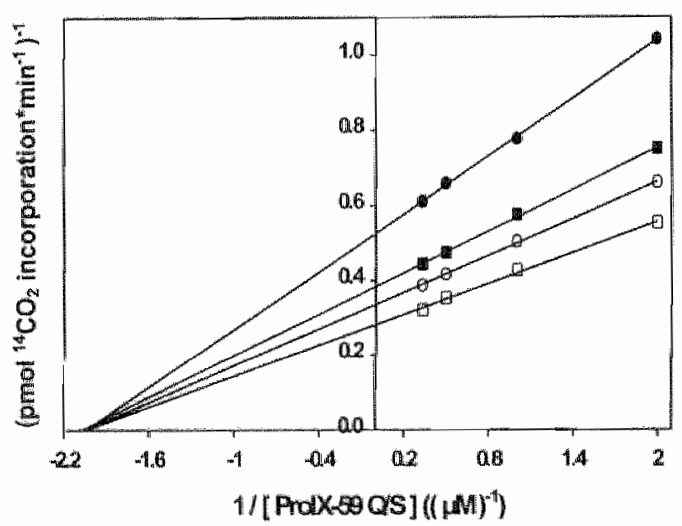

Fig. $1 \mathrm{~B}$

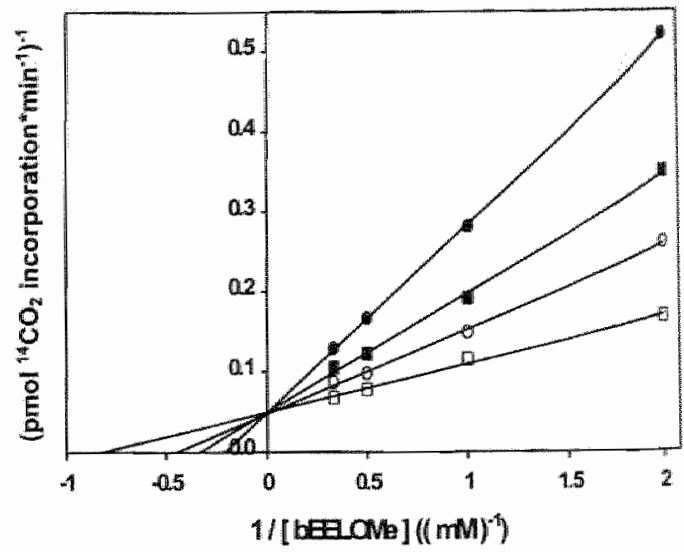

Fig. 1 D

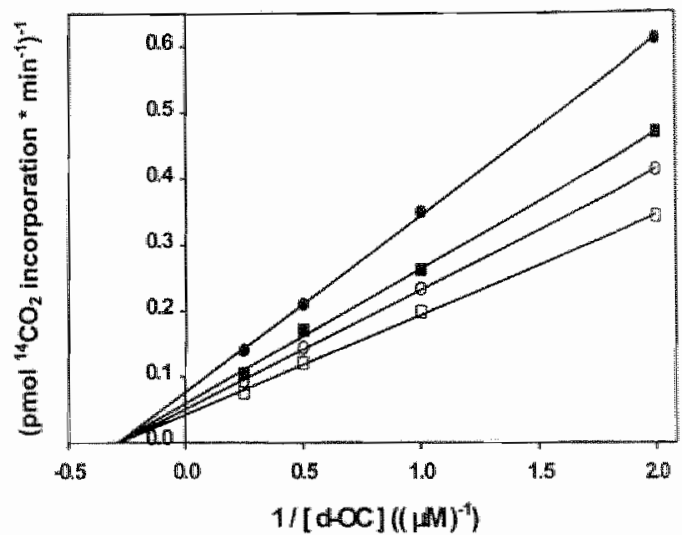

Figure 1: Lineweaver-Burk diagrams of substrate carboxylation. (A): Inhibition of ProlX-59 Q/S by increasing amounts of free propeptide of the precursor molecule of human blood

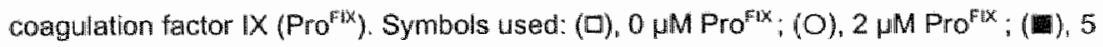

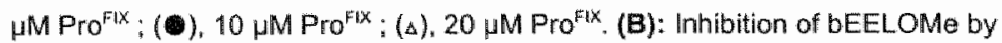
increasing concentrations of S-MeTPT. (C): Inhibition of ProlX.59 Q/S by increasing amounts of S-MeTPT. (D):Inhibition of d-OC by increasing amounts of S-MeTPT.

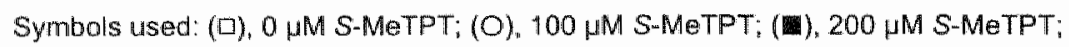
(C) $400 \mu M$ S-METPT. 


\section{Discussion}

The propeptide sequences which can be found in all precursors of Gla-containing proteins show substantial sequence similarity; notably the aminoacid residues at -16 , $-10,-4$ and -1 are highly conserved. Osteocalcin however, is the only known Glaprotein of which the propeptide sequence contains a glycine residue at the -10 position instead of the highly conserved alanine residue present in all other propeptides. Chu et al. have shown that an $\mathrm{Ala}^{-10} \rightarrow$ Thr mutation in the propeptide of human coagulation factor IX leads to a 30 -fold decreased affinity of the protein precursor for carboxylase in vitro, and hence, to a strongly increased sensitivity for warfarin in vivo ${ }^{14}$. Using substrates derived of ProlX-59 Q/S it was shown that an Ala $^{-10} \rightarrow$ Gly mutation in the propeptide induced a similar effect in vitro.

These data may explain why in previous experiments the propeptide of osteocalcin did not seem to play a role in the binding of $d-O C$ to carboxylase?

In our attempts to characterize the differences between the binding to carboxylase of propeptide-containing substrates and of d-OC we have used inhibitors interacting with the propeptide binding site or with the active site of carboxylase. It was demonstrated that the carboxylation of ProlX-59 Q/S, and more generally the carboxylation of propeptide containing substrates, is competitively inhibited by Pro ${ }^{\mathrm{FIX}}$. Since the primary structure of d-OC lacks a propeptide and has no marked sequence similarity with any of the known propeptides, it seems unlikely that the propeptide binding site on carboxylase plays a major role in the binding to $\mathrm{d}$-OC. The question remains, therefore, how to explain the high affinity of d-OC for carboxylase.

In agreement with previous data from Azerad et al. ${ }^{15}$, we found that the carboxylation of the short peptide substrate bEELOMe was competitively inhibited by S-MeTPT. In contrast, inhibition of both ProlX-59 Q/S and d-OC carboxylation by SMeTPT was non-competitive, suggesting that interaction with the active site is necessary for carboxylation, but does not play a major role in the high enzymesubstrate affinity. We therefore postulate the presence of an internal high affinity binding sequence within the mature sequence of $d-O C$ which binds neither to the propeptide binding site nor to the active site on $\gamma$-glutamylcarboxylase. This implies 
that, besides its active site, carboxylase contains at least two distinct sites for binding of different substrate types (e.g. propeptide-containing substrates and d-OC). Both the location of the $d-O C$ binding site on carboxylase as well as the position of the high affinity binding site within $\mathrm{d}-\mathrm{OC}$ remain to be established.

Though no clear function can be attributed to the osteocalcin propeptide yet, the question remains why this sequence is present during osteocalcin biosynthesis. Speculating about its possible function we would like to point out that by the binding of covalently attached propeptides, a substantial decrease in the $K_{m}$ for vitamin $K$ hydroquinone is induced ${ }^{16}$. Obviously this decreases the requirement for vitamin $K$, the dietary intake of which seems to be close to the published RDA values ${ }^{17}$. Also, the substantial under-carboxylation generally observed in human osteocalcin and its strong response to vitamin $\mathrm{K}$-supplementation demonstrates that human daily vitamin $K$ intake hardly covers the requirement for osteocalcin carboxylation ${ }^{18}$. It is possible therefore, that propeptide of osteocalcin is necessary for decreasing the $K_{m}$ for the carboxylase cofactor vitamin $\mathrm{K}$ hydroquinone. Whether this is really the case remains to be investigated. 


\section{References}

1. Engeike, J. A., Hale, J. E., Suttie, J. W. \& Price, P. A. Vitumin K-dependent carboxylase: utillzation of decarboxylated bone Gla protein and matrix Gla protein as substrates. Biochm Biophys Acta 1078, 31$34(1991)$.

2. Jorgensen, M. J. et al Recognition site directing witamin K-dependent gamma-carboxylaton resides on the propeptide of factor $(X$. Cell 48, 185-19114987).

3. Ulrich. M. M. Furie, B., Jacobs, M. R. Vermeer, C. \& Furie, B. C. Vitamin Kadependent carboxylathon. A synthetic peptide based upon the gamma-carboxylation recognition site secuence of the prothrombin propeptide is an active substrate for the carboxylase in vitro. J Biol Chem 263, 9697-9702 (1988).

4. Wu, S. M., Soute, B. A. M., Vermet, C. \& Stafford, D. W. In witro gamma-carboxylation of a 5 sitresidue recombinant peptide including the propeptide and the gamma-calboxyglutamic acid domain of coagulation factor $\mathbb{X}$. Effect of mutations near the propeptide cleavage site. J Biol chem 265, 13124$1329(1990)$

5. Suttie, J. W. \& Jackson, C. M. Prothrombin siructure, activation, and biosynthesis. Physiol Rew $57,4-70$ $(1977)$.

6. Suttie, J. W. Lehrman, S. R. Geweke, L. O. Hageman, J. M. \& Rlch, D. H. Witamin K-dependent carboxylase: requirements for carboxylation of soluble peptide and substrate specificity. Biochem Biophys Res Commun 86, 500-507 (1979).

7. Houben, R. J. T. J. ef al. Osteocalcin binds tightly to the gamma-glutamylcarboxylase at a sitte distinct from that of the other known witamin K-dependent proteins. Brochem $/ 341,265-269$ (1999).

8. Soutte, B. A. M., Acher, F., Azerad, R. \&ermeer, C. Vitamin K-clependent carboxylase; effect of ammonium sulfate on substrate carboxylation and on inthition by stereospecific substrate analogs. Biochim Biophys Acta 1034, 11-16 (1990).

9. Wuyts. A. et al. Characterization of synthetic human granulocyte chemotactic protein 2 usage of chemokime receptors CXCR1 and CXCR2 and in wivo inflammatory properties. Blachemistry 36, 2716. $2723(1997)$

10. Righini Tapie, A.\& Azerad, R. An enzymatic synthesis of 4methyl-Lolutamic acid diastereoisomers. $d$ Appl Biochem $361-366(1984)$.

11. Bory, S., Dubois, ., Gaudry, M. \& Marquet, A. Vitamin-K-dependent carboxylation. Synthesis and biological properties of diastereousomeric gamma-substituted glutamic acid containing peplidic substrates. Int J Pept Protein Res 24, 505-515 (1984) Decottignes Le Marechial. P., Ducrocq. C. Marquet. A. \& Azerad, R. The stereochemistry of hydrogen abstraction in vitamin K-dependent carboxylation. I Biol Chem 259 , 15010-15012 (1984). Stryer, 1 in Blochemistry 477-200 (W.H. Freeman and Company, New York, 1988). Chu, K. Wu, S. M. Stanley, T.B., Stafford, D. W. High, K. A. A mutation in the propeptide of Factor IX leads to warfarin sensitivity by a novel mechanism [se comments]. I Chn lnwest $98,1619-1625$ (1996).

Azerad. R., Decottignies-le Warechat, P., Ducroca, C., Righini-Tapie, A. Vidal-Cros, A., Bory, S., Dubois. W. Gaudry, M. and Marquet, A. in Current Adwances in Vitamin K Research (ead. Suttia, W. W.) $17-23$ (Elsevier Science Publishing Co., Inc., New York, 1988).

Soute, B. A. M. et al. Congenital deficiency of all vitamin K-dependent blood coagulation factors due to 
a defectwe vilumin K-dependent carboxylase in Dewon Rex cats. Thromb Haemost 68, 521-525 (1992).

17. Qooth, S. L., Penrington, J. A. \& Sadowski, J. A. Food sources and dietary intakes of vitamin K-1 (phylloquinone) in the American diet: data from the FDA Total Diet Study. I Am Dief Assoe 96, 149-154 $(1986)$

18. Krapen, M. H. Jie, K. S., Hamulyak, K. \& Vemeer, C. Vitamin K-induced changes in markers for osteoblatat activity and urinary calcium logs. Calcif Tissue int 53, 81-85 (1993). 


\section{Chapter 6}

\section{THE COMPOSITION OF THE VITAMIN K-DEPENDENT GAMMA-GLUTAMYL CARBOXYLASE BINDING DOMAIN ON OSTEOCALCIN}

Roger J.T.J. Houben *, Dirk T.S. Rijkers , S. M.Käkönen", Cees Vermeer ${ }^{\ddagger}$ and Berry A.M. Soute ** $^{*}$

"Department of Biochemistry and Cardiovascular Research Institute, Maastricht University" The Netherlands; \$Department of Medicinal Chemistry, Institute for Pharmaceutical Sciences, Utrecht University, The Netherlands and "Department of Biotechnology, University of Turku, Finland. 
था 


\section{Abstract}

Descarboxy-osteocalcin (d-OC) possesses a high affinity recognition site for the vitamin K-dependent enzyme $\gamma$-glutamyl carboxylase. This recognition site is distinct from the conserved propeptide which serves as a carboxylase binding site in other precursor proteins. However, the exact location and composition of the $\gamma$-glutamyl carboxylase recognition domain on d-OC has remained unclear until now. With the use of various synthetic peptides derived from the $\mathrm{N}$-terminal part of $d-O C$ we report here that the main recognition sequence present on d-OC resides between residues 1 and 12 , at the $\mathbb{N}$-terminal site of the $\gamma$-carboxy glutamic acid (Gla) domain. By shortening the $N$ terminal part of $\mathrm{d}-O \mathrm{C}^{1-25} \mathrm{using}$ deletions of amino acids 1 and 2 (d-OC ${ }^{4-25}$ ), 1 to 4 (d-OC $\left.{ }^{5-25}\right), 1$ to $6\left(\mathrm{~d}-\mathrm{OC}{ }^{7-25}\right), 1$ to $9\left(\mathrm{~d}-\mathrm{OC}{ }^{10-25}\right)$ and 1 to $12\left(\mathrm{~d}-\mathrm{OC}{ }^{19-25}\right)$, the $K_{\mathrm{m}}$ values for $\mathrm{V}$ glutamylcarboxylase gradually increased. Besides the residues 1 to 12 , a second recognition unit is located between residues 26 to 39 , C-terminal of the Gla -domain which substantially contributes to the efficiency of carboxylation. This is the first time that a vitamin K-dependent substrate is reported of which the carboxylase binding domain is interrupted by the Gla-domain. 


\section{Introduction}

Descarboxy- osteocalcin ( $\mathrm{d}-\mathrm{OC}^{\mathrm{i}-49}$ ) is the only known vitamin $\mathrm{K}$-dependent protein that binds the enzyme $y$-glutamyl carboxylase with high affinity without the presence requirement of a covalently attached propeptide ${ }^{1-5}$. It also became clear that $\mathrm{d}-\mathrm{OC}{ }^{1-49}$ initially binds to carboxylase at a site distinct from both the propeptide binding site ${ }^{6}$ and the active site (Chapter 5 , this thesis). However, the question remained which structural determinants of $d-O C^{1-49}$ contribute to its high affinity for carboxylase. Although in vivo the precursor molecule of osteocalcin is covalently attached to its propeptide, it has been demonstrated that this propeptide does not possess measurable affinity for carboxylase and therefore probably does not improve the enzyme-substrate interaction ${ }^{6}$. Whether this is a consequence of the presence of a glycine residue at the -10 position of the propeptide instead of the highly conserved alanine residue, seen in all other propeptides of the vitamin K-dependent proteins, remains to be examined. Chu et al. reported a factor $\mathrm{IX}$ precursor molecule which displayed a 30 fold reduced affinity for carboxylase as a result of an alanine to threonine mutation at the -10 position of the propeptide ${ }^{7}$. A similar decrease was also observed if an alanine to glycine mutation was introduced at the same position in the propeptide of the factor IX precursor molecule $^{7}$. Moreover, within the osteocalcin propeptide a valine residue is present at the -6 position of the propeptide, whereas most other propeptides possess a leucine at this position. Whether these differences contribute to the poor affinity of the osteocalcin propeptide is still unclear.

Within the mature amino acid sequence of osteocalcin no homology with a propeptide structure can be found, in contrast to Matrix Gla Protein (MGP), which is the only vitamin K-dependent protein that has developed a propeptide within its mature amino acid sequence ${ }^{\text {a }}$. Stanley et al. already postulated that for osteocalcin essentiall elements other than the propeptide appear to be involved in substrate recognition ${ }^{2}$. This is in contrast with the postulation of Price ef al., who speculated about the EXXXEXC unit which could allow the carboxylase molecule to discriminate between substrate and product and which might be involved in substrate recognition and product dissociation ${ }^{8}$. From previous experiments it became evident that the highly conserved EXXXEXC 
consensus sequence present in the Gla domain of all known vitamin K-dependent proteins did not contribute to a high affinity binding in case of the d-OC $\mathrm{C}^{13-25}$ peptide ${ }^{3}$.

To investigate which domain within the $\mathrm{d}-\mathrm{OC}$ protein is responsible for the high affinity bind ing to carboxylase, the peptides $d-O C^{1-25}, d-O C^{3-25}, d-O C^{5-25}, d-O C^{7-25}$, $\mathrm{d}^{\mathrm{O}} \mathrm{OC} \mathrm{C}^{10-25}$ were synthesized and their $\mathrm{K}_{\mathrm{m}}$ values were compared with those of $d-O \mathrm{C}^{1-49}$, d-OC ${ }^{13-25}$, and two recombinant glutathion- S-transferase (GST) fused human descarboxy-osteocalcin molecules, GST-rhOC ${ }^{1-49}$ and GST-rhOC ${ }^{1-39}$. 


\section{Materials and Methods}

\section{Reagents}

All chemicals were of analytical grade or better. Vitamin $K_{\text {. }}$ (Konakion ${ }^{3}$, mixed-micelles) was purchased from Hoffmann - La Roche (Basel, Switzerland), $\mathrm{NaH}^{14} \mathrm{CO}_{3}$ with a speciffic activity of $50 \mathrm{mCl} / \mathrm{mmol}$ was from NEN (Boston, MA) and CHAPS $\{3-[(3-$ cholamidopropyl) dimethylammonio]-1-propane sulfonate\} was from Sigma (St. Louis, MO).

\section{Proteins and peptides}

Recombinant glutathion S-transferase (GST) fused human descarboxy-osteocalcin (GST-rhOC ${ }^{1-49}$ ) and a GST-fused truncated form of human descarboxy-osteocalcin lacking $10 \mathrm{COOH}$-terminal amino acid residues, (GST-rhOC ${ }^{1-39}$ ) were produced and purified according to Käkönen et al. ${ }^{9}$ and Hellman et al. ${ }^{10}$ "respectively. $\mathrm{d}-\mathrm{OC}{ }^{1-49}$ was synthesized by Dr. P Proost (The Rega Institute, Department of Molecular Immunology, Catholic University of Leuven, Belgium), according to Wuyts et al. ${ }^{1 !}$. d-OC ${ }^{13-25}$ was purchased from Pepscan Systems (Lelystad. The Netherlands).

The peptides $d-O C^{1-25}, d-O C^{3-25}, d-O C{ }^{5-25}, d-O C^{7-25}$ and $d-O C^{10-25}$ were synthesized on an Applied Blosystems 433A Peptide Synthesizer (Foster City, California, USA) using the FastMoc protocol $^{12}$ on 0.25 mmol scale. Peptide syntheses

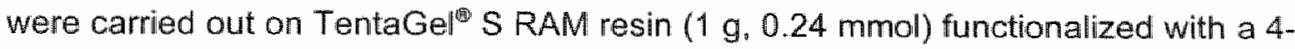
$\left[\left(2^{\prime}, 4\right.\right.$ '-dimethoxyphenyl)aminomethyl]phenoxyacetamido moiety (Rink amide linker ${ }^{i 3}$ ) (Rapp Polymere. Tübingen, Germany) to obtain C-terminal amides. $\mathbb{N}^{a} 9$ fluorenylmethyloxycarbonyl (Fmoc) -protected amino acids with the following side chain protection were used: tert. -butyloxycarbonyl (Boc) for Trp ${ }^{14}$, tert-butyl (tBu) for Tyr, tert. butyl ester (OtBu) for Asp and Glu, trityl (Trt) for Glin and Cys and 2,2,4,6,7pentamethyl-dihydrobenzofuran-5-sulfonyl (Pbf) for Arg ${ }^{45}$. Coupling of N-Fmoc amino acids (1 mmol, 4 equiv) were performed with 2-(1H-benzotriazol-1-yl)-1,1,3,3tetramethyluronium tetrafluoroborate/N-hydroxybenzotriazole (HBTU/HOBt) ${ }^{\text {t6 }}$ in the presence of 2 equiv $N, N$-disopropylethylamine (DIPEA) in N-methylpyrrolidinone (NMP) for 45 min. Fmoc removal was carried out with $25 \%$ piperidine in NMP for 10 min. The 
peptides were cleaved from the resin and deprotected by treatment with trifluoroacetic acid (TFA)/ $\mathrm{H}_{2} \mathrm{O} / 1,2$-ethanedithiol 76:4:20 v/V/V at room temperature for $3 \mathrm{hrs}{ }^{~}{ }^{\text {" }}$. The peptides were precipitated with diethyl ether $/$ hexane $1: 1 \mathrm{v} / \mathrm{v}$ at $-20^{\circ} \mathrm{C}$. The precipitates were decanted and subsequently washed with cold diethyl ether/hexane 1:1 v/v (three times) and finally lyophilized from tert.-butanol/ $\mathrm{H}_{2} \mathrm{O} 1: 1 \mathrm{w} / \mathrm{v}$.

\section{Peptide purification}

Preparative HPLC runs were performed on a Gilson HPLC workstation (Middleton, Wisconsin, USA) using Adsorbosphere XL C18 (Alltech Corp., Deerfield, llinois, USA), consisting of two 306 pumps, a $811 \mathrm{C}$ dynamic mixer, a 806 manometric module, a 119 UVN/S detector a 402 syringe pump and a $233 \mathrm{XL}$ on-line column switching autoinjector (fractioncollector). The HPLC runs were controlled by Gilson Unipoint ${ }^{\mathrm{rm}}$ System Software (version 1.65). Preparative HPLC was performed on Adsorbosphere XL C18 (Alltech Corp., Deerfield, ilinois, USA), $10 \mu \mathrm{m}$ particle size, 300 A pore size (l: $250 \mathrm{~mm}$. i.d.: $22 \mathrm{~mm}$ ). Crude lyophilized peptides ( $30-100 \mathrm{mg}$ ) were dissolved in $0.1 \%$ TFA in $\mathrm{H}_{2} \mathrm{O}$ and loaded onto the HPLC column. The peptides were eluted with a flow rate of $11.5 \mathrm{~mL} /$ min using a linear gradient of buffer $\mathrm{B}(100 \%$ in $60 \mathrm{~min}$ ) (buffer $\mathrm{A}: 0.1 \%$ TFA in $\mathrm{H}_{2} \mathrm{O}$, buffer $\mathrm{B}: 0.085 \%$ TFA in $\mathrm{CH}_{3} \mathrm{CN} / \mathrm{H}_{2} \mathrm{O} 95: 5 \mathrm{v} / \mathrm{v}$ ). After purification the peptides were lyophilized from demineralized water and stored at $-20^{\circ} \mathrm{C}$ prior to biological testing.

\section{Peptide characterization}

Peptide purity was analyzed by analytical HPLC on an Adsorbosphere XL C18, $5 \mu \mathrm{m}$ particle size, $300 \AA$ pore size (l: $250 \mathrm{~mm}$, i.d.: $4.6 \mathrm{~mm}$ ) at a flow rate of $1 \mathrm{~mL} / \mathrm{min}$ using a lineair gradient of buffer $B(100 \%$ in $30 \mathrm{~min}$ ) from $100 \%$ buffer $A$ (buffer $A: 0.1 \%$ TFA in $\mathrm{H}_{2} \mathrm{O}$; buffer $\mathrm{B}: 0.085 \%$ TFA in $\mathrm{CH}_{3} \mathrm{CN} / \mathrm{H}_{2} \mathrm{O} 95.5 \mathrm{v} / \mathrm{v}$ ). Purity was determined to be $95 \%$ or higher. The peptides were characterized by Electrospray lonization Mass Spectrometry (ESI-MS) on a Micromass Platform II (Micromass UK Ltd., Altrincham. United Kingdom) single quadrupole bench-top mass spectrometer operating in a positive ionization mode. Instrumental control, data acquisition and data processing 
were carried out using the MassLynx software package (version 2.3). The observed average $m / z$ was compared with the calculated $(M+H)^{*}$ average mass. An overview of the mass comparison is given in table 1.

\section{Table 1}

Comparison of Obtained and Calculated Molecular Masses

of the Synthesized d-OC Peptides

\begin{tabular}{|c|c|c|c|}
\hline \multirow[t]{2}{*}{ Osteocalcin } & \multirow[t]{2}{*}{ Peptide Amino Acid Composition } & \multicolumn{2}{|c|}{ Molecular Mass $(M+H)+*$} \\
\hline & & Obtained & Calculated \\
\hline$d-0 C 1-25$ & AC-YLYOWLGAPVPYPDPLEPRREVCEL-NH & 3046.20 & 3046.53 \\
\hline d-OC $3-25$ & AC-YQWLGAPVPYPDPLEPRREVCEL-NHH & 2769.60 & 2770.19 \\
\hline $\mathrm{d}-\mathrm{OC} 5-25$ & AC-WLGAPVPYPDPLEPRREVCEL-NH & 2478.35 & 2478.88 \\
\hline$d-O C 7-25$ & AC-GAPVPYPDPLEPRREVCEL-NH & 2179.45 & 2179.51 \\
\hline$d-O C \quad 10-25$ & AC-VPYPDPLEPRREVCEL-NH & 1953.30 & 1952.99 \\
\hline
\end{tabular}

Carboxylase assay

Expression of r-carboxylase in Trichoplusia ni High-Five insect cells the preparation of microsomes and the purification of r-carboxylase using HPC4 antibody resin was performed as described ${ }^{6}$. Standard reaction mixtures were used as described ${ }^{6}: 25$ nmol of HPC4 purified $y$-glutamyl carboxylase was used. 


\section{Results and Discussion}

In a purified recombinant human $\gamma$-glutamyl carboxylase system devoid of any endogenous substrate, we have determined the $K_{m}$ - and $V_{\text {max }}$ values of various $d-O C$ peptides and proteins. As can be seen in table 2, N-terminal deletion of amino acids of the $d-O C^{1-25}$ peptide results in an increase in the $K_{m}$ values of these peptides. Experiments in which we compared d-OC ${ }^{1-49}$ with chimeric proteins in which the $\mathrm{N}$ terminus of d-OC was fused with GST, showed that recognition of d-OC by carboxylase was not influenced by the relatively large GST (Mw $26 \mathrm{kDa}$ ). This is important because in proteins containing the pro-sequence only the first $n \mathrm{~N}$-terminal glutamate residues (where $n$ ranges from 5 to 12) are carboxylated. The newly discovered "OC-type" carboxylation recognition sequence (CRS) makes clear that -although no such protein has been discovered at this time-also a Gla-domain in the center or at the C-terminus of a protein is feasible. Another remarkable point was that the CRS in OC is formed by sequences located both at the $\mathrm{N}$-terminal and $\mathrm{C}$-terminal side of the Gla-motif. This became clear from comparison of the characteristics of $d-O C C^{1-49}$ and $d-O C^{1 \cdot 25}$. Since deletion of the last 10 carboxy-terminal residues had no effect, the contribution to carboxylase recognition must also be associated with residues 26-39.

Supposedly, the binding of the d-OC peptides to carboxylase results in a processive mechanism of carboxylation, similar to carboxylation of propeptidecontaining substrates, although d-OC ${ }^{1-49}$ lacks a propeptide. The rate of release of the substrate must be slower than the rate of carboxylation ${ }^{2}$. This process is described for the propeptide-containing substrate $F \mid X Q / S$, a recombinant substrate based on the amino acids -18 to 41 of the human factor IX precursor molecule ${ }^{18}$, identical with ProlX$59 \mathrm{Q} / \mathrm{S}$. FIXQ/S binds carboxylase and is released after all 12 glutamate residues are converted. Therefore, the rate of carboxylation is proportional to the number of glutamate residues which can be carboxylated during a single enzyme turnover. Thus, the $V_{\max }$ is rate-limited by the substrate bound. This process results in $V_{\max }$ values for pro-containing substrates that are 5 to 10 -fold lower than the $V_{\text {max }}$ values of FLEEL or d-OC ${ }^{13.25}$ as can be seen in table 3 . This mechanism furthermore depends on the 
differences in affinity of the propeptides. It is known that the affinity of the factor IX propeptide is 10 -fold higher than of the prothrombin propeptide 19. 


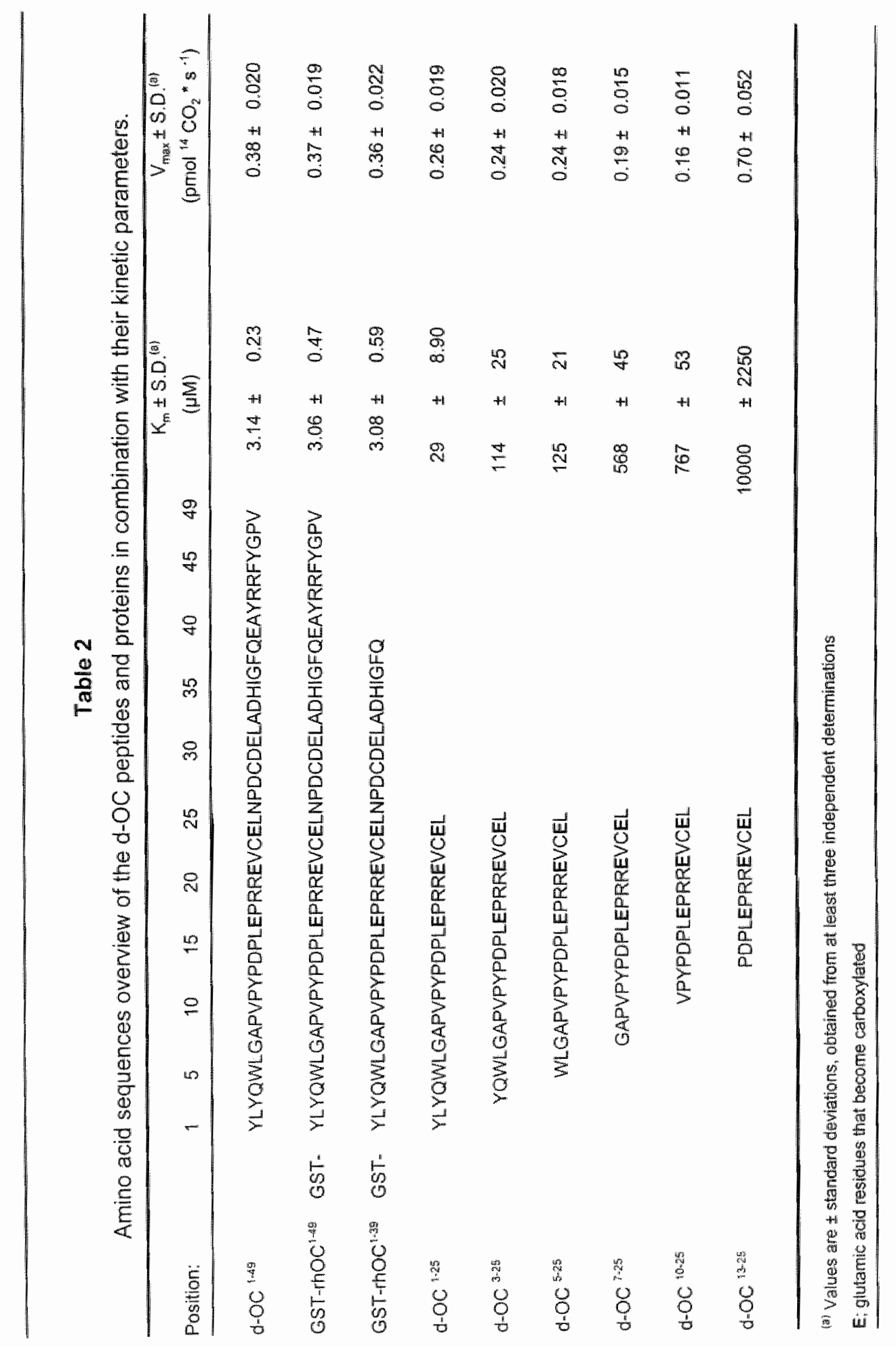


This difference may explain why the $V_{\max }$ of ProPT -28 , containing only 2 glutamate residues is still 2-fold higher than the $V_{\max }$ of ProlX-59 Q/S.

Using the formula

$$
\text { E.C. }=\frac{V_{\max } /[E]}{K_{m}^{*} \text { Glu }}
$$

It is possible to calculate the efficiency of carboxylation for different substrates, in which E.C. stands for efficiency of carboxylation, $[E]$ is the carboxylase concentration in the reaction mixture $(\mathrm{pmol} / \mathrm{ml}), \mathrm{V}_{\max }$ is the maximal amount of ${ }^{14} \mathrm{CO}_{2}$ incorporated (pmol/s), and $K_{m}{ }^{*}$ Glu is the $K_{m}$ adjusted for the theoretical number of the potentially carboxylated glutamate residues per substrate molecule.

\section{Table 3}

Carboxylation Efficiency of Various In Vitro Substrates

\begin{tabular}{|c|c|c|c|}
\hline Substrate ${ }^{(5)}$ & $\begin{array}{l}K_{m} \\
(\mu M)\end{array}$ & $\begin{array}{c}V_{\max } \\
\text { (pmol }{ }^{14} \mathrm{CO}_{2} \text { incorporated } \text { s }^{-1} \text { ) }\end{array}$ & $\begin{array}{c}\text { Carboxylation Efficiency } \\
\qquad\left(\text { (mol }^{-1} * \mathrm{~s}^{-1}\right)\end{array}$ \\
\hline $\mathrm{d}^{-} \mathrm{OC}$ & 3.14 & 0.38 & 1.61 \\
\hline GST-rhOC & 3.08 & 0.37 & 1.61 \\
\hline GST.rhOC 1-49 & 3.00 & 0.35 & 1.55 \\
\hline Pro $(G \mid u)_{10}$ & 0.56 & 0.13 & 0.93 \\
\hline ProPT-28 F/A & 5.35 & 0.22 & 0.82 \\
\hline ProlX-59 Q/S & 0.51 & 0.10 & 0.65 \\
\hline$d-O c^{4 \cdot 25}$ & 29 & 0.27 & 0.13 \\
\hline $\mathrm{d}-\mathrm{OC}$ & 114 & 0.25 & 0.029 \\
\hline$d-O c^{5-25}$ & 125 & 0.25 & 0.027 \\
\hline $\mathbb{d}-O C^{i-25}$ & 568 & 0.20 & 0.0047 \\
\hline FLEEL & 2400 & 0.47 & 0.0039 \\
\hline $\mathrm{d}-\mathrm{OC} \mathrm{C}^{10.25}$ & 767 & 0.15 & 0.0026 \\
\hline DEELOME & 2000 & 0.22 & 0.0022 \\
\hline $\mathrm{d}-O \mathrm{C}^{13 \cdot 25}$ & 10000 & 0.70 & 0.0009 \\
\hline
\end{tabular}

(a) See chapter 4 for a description of the propeptide-containing substrates. 
As is shown in table 3 the efficiency of carboxylation can be devided in three groups: low efficiency $\left(0.0009-0.0047 \mathrm{~mol}^{-1 *} \mathrm{~s}^{-1}\right)$ for the short peptides including FLEEL, $d-O C{ }^{13-25}, d-O C^{10-25}$ and $d-O C^{7-25}$, intermediate efficiency $\left(0.027-0.13 \mathrm{~mol}^{-1 *} \mathrm{~s}^{-1}\right)$ for $\mathrm{d}$ $O C^{5-25}$ through d-OC ${ }^{1-25}$, and high efficiency $\left(0.65-1.61 \mathrm{~mol}^{-1} \mathrm{~s}^{-1}\right)$ for the pro-containing substrates and full length osteocalcin. The efficiency of the propeptide-containing substrates is in the same range, independent of the amount of glutamate residues, but probably depending on the on/off rate of the propeptide. The efficiency by which FLEEL, bEELOMe, d-OC ${ }^{7-25}, \mathrm{~d}-O C^{10-25}$ and $\mathrm{d}-\mathrm{OC}{ }^{13-25}$ are carboxylated is strongly reduced because of a low affinity of these substrates. The low affinity explains why not more than one Gla/mol is formed before enzyme/substrate dissociation and thus why efficiency of carboxylation is low for short peptide substrates ${ }^{20,21}$. Obviously, this is undesirable for protein precursors in which formation of a complete multi-carboxylated product is required during one cycle of enzyme-substrate interaction. ProlX-59 Q/S is processively carboxylated, and the dissociation of the propeptide from the enzyme is rate limiting in this process ${ }^{18}$. All 12 glutamate residues are carboxylated by the enzyme in one binding event, thereby ensuring maximal carboxylated ProlX-59 Q/S to be formed. Since in wivo the substrate concentration is well below the $K_{m}$ value, replacement of bound substrate by an excess of free substrate will be an unlikely event, except in cases of unusual accumulation of precursor proteins for instance during vitamin K-deficiency or coumarin treatment. Indeed partially carboxylated coagulation factors have been reported to circulate in coumarin-treated humans ${ }^{22}$.

It remains unclear however why $\mathrm{d}_{-} \mathrm{OC} \mathrm{C}^{1-49}$ is carboxylated with 2 to 3 -fold higher efficiency as propeptide-containing substrates are. The question remains whether this is the reason why in humans undercarboxylated osteocalcin can be found in both bone ${ }^{23}$, and serum ${ }^{24-28}$. Alternatively, a local or tissue-specific vitamin K-deficiency in human bone might explain the occurence of undercarboxylated osteocalcin.

Although carboxylase displayed a low $K_{m}$ value for $d-O C{ }^{1-25}$ (table2), the efficiency by which it is carboxylated still is -12 -fold lower than for $\mathrm{d}-\mathrm{OC}{ }^{1-49}$ (table 3 ). It is clear that the C-terminal domain from residues 26 to 39 contributes to the carboxylation efficiency of $d-O C{ }^{1-49}$ to a major extent. 
However, the $V_{\text {max }}$ values of the $N$-terminal deleted d-OC peptides show a slight

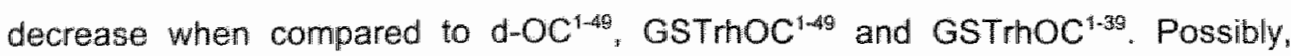
substrates which bind with high affinity at either the propeptide binding site or the osteocalcin binding site on carboxylase induce a conformational change in the catalytic domain of the enzyme, thereby directing the active site of the enzyme towards the substrate glutamate residues ${ }^{29}$. This subsequently results in the carboxylation of the glutamate residues on the substrate. If the affinity of these substrates is reduced by deletion of specific amino acids, the conformational change in the catalytic domain can be less pronounced and thereby lower the $V_{\max }$.

From the results presented here we can furthermore draw the conclusion that the $E X X X E X C$ consensus sequence, as was postulated by Price et al. ${ }^{8}$ does not contribute to the high affinity recognition of osteocalcin by carboxylase. The $d-O C^{13-25}$ peptide, which consists of residues 13 to 25 of descarboxy-osteacalcin $(P D P L E P R$ REVCE L; the EXXXEXC-part is underlined), has a $K_{m}$ that is 3 orders of magnitude higher than that of $d-O C^{1.49}$ and $d-O C{ }^{1-25}$. This is in agreement with results found by Ratcliffe et al., who used prothrombin mutants in which glutamic acid residues were modified to aspartic acid, generating fully carboxylated proteins ${ }^{30}$. Furthermore it was shown by several authors using in vitro substrates consisting of a propeptide followed by a random Glu-containing protein sequence, that the EXXXEXC motif is redundant in substrate recognition ${ }^{1,2,31}$.

In conclusion, we have demonstrated that the $\mathrm{d}-\mathrm{OC}$ molecule binds to carboxylase in a different way when compared to the other known vitamin K-dependent proteins. The results of the experiments described in this paper indicate that carboxylase recognizes a $d-O C$ by two specific regions flanking the Gla-domain, which is distinct from the propeptide domain. The carboxylase binding domain described here seems specific only for osteocalcin, but might also be avalable for currently undiscovered vitamin K-dependent proteins lacking a propeptide motif. These proteins of yet unknown structure and function could be capable of binding carboxylase with high affinity in a propeptide-independent way. 


\section{Acknowledgements}

The authors wish to thank Dr. Paul Proost for the synthesis of $d-O C^{1-49}$ and Dr. Rob H.M. Ebberink, Perkin - Elmer Netherlands Ltd, Nieuwerkerk aan de IJssel, The Netherlands, for generously providing us with the d-OC ${ }^{1-49}$. 


\section{References}

1. Houben, R.J.T.J., Soute, B. A.M. Vermeer, C. Assay of witarm K-dependent carboxylase activity in hepatic and extrahepatic tissues. Methods Enzymol 282, 358-368 (1997).

2. Stanley, T. B., Wu, S.M., Houben, R.J.T.J. Mutucumarana, W. P. \& Stafford, D. W. Role of the propeptide and gammerglutamic acid domain of factor $\| X$ for in vilo carboxylation by the witamin K-dependent carboxylase. Biochemistry 37, 13262-13268 (1998).

3. Soute, B. A.M., de Met, M. Vermeer, C. Characteristics of vitamin Kmependent carboxylating systems from human liver and placenta. FEBS Lett 146, 365-368 (1982).

4. Ulrich, M. M. Soute, B. A.M., wan Haartem, L. I. \& Vermeer, C. Substrate recognition by vitamin Kdependent carboxylase. Thromb Haemost 57, 17-19(1987).

5. Vermeer, C., Soule, B. A.M., Hendrix, H. \& de Boer wan den Berg, M. A. Decarboxylated bone Gla-protein as a substrate for hepatic wtamin K-dependent carboxylase. FEBS LeV1 165, 16-20 (1984).

6. Houben, R. J. T. J. ef al. Osteocalcin binds tightly to the gamma glutamylcarboxylase at a sitie distinct from that of the other known witamin K-dependent proteins. Biochem $J 341,265-269$ (1999).

7. Chu, K. Wu, S.M. Stantey, T., Stafford, D. W. \& High, K. A. A mutation in the propeptide of Factor X laads lo warfarin sensitivity by a novel mechanism [see comments]. J Clin huvesi $98,1619-\$ 625$ (1996)

8. Price, P.A. Fraser J. D. \& Met Virca, G. Molecular cloning of matrix Gla protein: implications for substrate recognition by the witamin K-dependent gamma-carboxylase. Proc Natl Acad Sci USA 84, 8335-8339 (1987).

9. Kakonen, S. M., Hellman, J., Pettersson, KK, Lovgren, T. \& Karp, M. Purification and characterization of recombinant osteocalcin fusion protein expressed in Escherichia coll. Protein Expr Purif 8, 137-144(1996).

10. Hellmain. J ef al. Epitope mapping of nine monoclonal antibodies against osteocalcin: combinations into two-site assays affect both assay specificity and sample stability. J Bone Miner Res 11, 1165-1175 (1996).

11. Wuyts, A. et al. Chatacterization of synthetic tuman granulocyte chemolactic protein 2 : usage of chemokine receptors CXCR1 and CXCR2 and in vivo intiammatory properties. Biochemistry 36, 2716-2723 (1997).

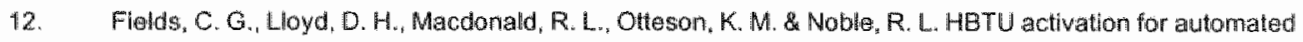
Fmoc solid-phase peptide synthesis. Pept Res 4, 95 -101 (1991).

13. Rimk, H. Tetrahedron Lett 28, 3787-3790 (1987).

14. White, P. in "Peptides, Chemistry and Biohogy" Proc. 12 th American Peptide Symposium feds. Smilth. J. A. \& Rivier. J. E.) 537.538 (ESCOM Leiden, the Netherlands.1992).

15. Carpino, L. A. er al. Tetrahedron Left 34, 7829-7832 (1993).

16. Knorr, R., Trzeciak, A., Banmwath, W. \& Gillesen, D. Tetrahedron Lett 30, 1927-1930 (1989).

17. Riniker, B. Florsheimer, A, Fretz, H., Sieber, P. Kamber, B. Tetrahedron Latt 49. $9307-9320$ (1993).

18. Morris, D. P., Stevens, R. D. Wright, D. J. \& Stafford, D. W. Processive post-translational modification. Vitamin K-dependent carboxylation of a peptide substrate. Wiol Chem 270, 30491-30498 (1995).

19. Stanley, T. B., Jin, D. Y., Lin, P. J. Stafford, D. W. The propeptides of the vitamin K-dependent proteins possess different affinities for the vitamin Ki-dependent carboxylase. J Bior Chem 274, 16940-16944 $(1999)$ 
20. Decottignies-Le Marechal, P., Rikong-Aide, H., Azerad, R. \& Gaudry, M. Vitamin K-dependent carboxylation of synthetic substrates. Nature of the products. Biochem Biophys Res Commun $90,700-707$ (1979).

21. Soute, B. A. M. Ulrich, M. M. \& Vermeer, C. Vitamin K-dependent carboxylase: increased efficiency of the carboxylation reaction. Thromb Haemost 57, 77-81 (1987).

22. Friedman, P. A., Rosenberg, R. D., Hauschka, P. V. \& Fiz-James, A. A spectrum of partially carboxylated prothrombins in the plasmas of coumarin-treated patients. Biochim Biophys Acta 494; 271-276 (1977).

23. Caims, J.R. \& Price, P. A. Direct demonstration that the vitamin K-dependent bone Gla protein is incompletely gamma-carboxylated in humans. $J$ Bone Miner Res $9,1989-1997$ (1994).

24. Knapen, M. H., Hamulyak, K. \& Vermeer, C. The effect of witamin $K$ supplementation or circulating osteocalcin (bone Gla protein) and urinary calcium excretion. Ann-Mntem-Med 111, 100 1-5 issn: 0003-4819 (1989).

25. Szulc. P., Chapuy, M. C. Meunier, P. J. \& Delmas, P. O. Serum undercarboxylated osteocalcin is a marker of the risk of hip fracture in elderly women. $J$ Clim divest $91,1769 \cdots 1774$ (1993).

26. Szulc, P. at al. Senum undercarboxylated osteocalcin correlates with hip bone mineral densily in elderly women. J Bone Miner Res 9, 1591-1595 (1994).

27. Sokoll, L. J., ME, O. B., Camilo, M. E. \& Sadowski, J. A. Undercarboxylated osteocalcin and development of a method to determine vitamin $K$ status. Clin Chem $41,1121-1 / 28$ (1995).

28. Liu, G. \& Peacock, M. Age-related changes in serum undercarboxylated osteocalcin and its relationships with bone density, bone quality, and hip fracture. Calcif Tissue Int 62, 286-289 (1998).

29. Furie, B. Bouchard, B. A. \& Furie, B. C. Vitamin K-Dependent Biosynthesis of gamma-Carboxyghutamic Acid. Blood 93, 1798-1808 (1999).

30. Riatcliffe, J. V., Furie, B. \& Furie, B. C. The importance of specific gamma-carboxyglutamic acid residues in prothrombin. Evaluation by site-specific mutagenesis. J Biol Chem 26i8, 24339-24345 (1993).

31. Furie, B. C. et al. The gamma-carboxylation recognition site is sufficient to direct vitamin K-dependent carboxylation on an adjacent glutamate-rich region of thrombin in a propeptide-thrombin chimera. $J$ Biol Chem 272, 28258-28262 (1997). 
Chapter 7

SUMMARY, CONCLUSIONS AND DISCUSSION 1

SAMENVATTING, CONCLUSIES EN DISCUSSIE 



\section{Summary, conclusions and discussion}

\section{Chapter 1}

During synthesis in wivo, proteins undergo extensive post-translational processing before being able to function appropriately. Some of these modified proteins are secretory proteins such as the Gla-proteins involved in blood coagulation or tissuemineralization processes. Carboxylation of specific glutamate (Glu) residues into $v$ carboxy glutamate (Gla) residues is one of the postranslational processes and is accomplished by the vitamin K-dependent enzyme $\mathrm{Y}$-glutamyl carboxylase. Vitamin Khydroquinone $\left(\mathrm{KH}_{2}\right)$ is the cofactor and an absolute requirement in the carboxylation process. During the conversion of Glu into Gla, $\mathrm{KH}_{2}$ is oxidized to vitamin $\mathrm{K} 2,3$ epoxide $(\mathrm{KO})$ in a 1:1 stoichiometry via an intermediate vitamin $\mathrm{K}$ alkoxide. Subsequently, KO is reduced in two steps; first to $\mathrm{K}$ by the enzyme $\mathrm{KO}$-reductase and then to $\mathrm{KH}_{2}$ by the enzyme K-reductase. Due to this "recycling" mechanism, the daily requirement in humans for vitamin $K$ is relatively low. The conversion of Glu to Gla is necessary for the calcium-binding properties of the Gla-proteins. Only a small number of all the known proteins in man are Gla-proteins. Therefore the Gla-proteins have to be distinguishable from other proteins so they can be recognized by the vitamin $K$-dependent carboxylase. For that aim, the precursor forms of the Gla-proteins possess a domain, a so-called propeptide, which makes them capable of binding to carboxylase with high affinity. The goal of this thesis was to gain insight in the determinants responsible for the recognition of the Glamprecursor molecule and carboxylase. For that purpose we have chosen to use substrates derived from the bone Gla-protein osteocalcin, from the precursor protein of human coagulation factor $\mathbb{X}$, and from the precursor protein of human prothrombin. In this chapter a review on the literature is presented concerning the history and current status of our knowledge regarding carboxylase, its cofactors and substrates. Moreover the function of the various Gla-proteins is discussed.

\section{Chapter 2}

The bone Gla-protein osteocalcin is unique in its ability to bind carboxylase with high 
affinity. To obtain sufficient amounts of this bone protein, several strategies can be applied. The first method is to purify the native protein from (bovine/human) bone. However, this technique has several disadvantages; (i) it is laborious with relatively low yields and in case of isolation from human bones (ii) the source is limited and there is a potential risk of infection. Besides these drawbacks, the protein obtained from bone is carboxylated and thus not usefull as an in vitro substrate for carboxylase. Thermal decarboxylation of native osteocalcin can be applied but may induce unwanted and unpredictable damage to the protein due to the reaction conditions of the procedure. As a second possibility, recombinant DNA techniques can be utilized to produce unlimited amounts of osteocalcin in bacteria (Escherichia coli). The osteocalcin produced in E. coll is not carboxylated and can be used as a substrate for carboxylase. Besides the synthesis in E.coli, chemical synthesis is a third possibility to obtain both carboxylated- $(O C)$ and descarboxy-osteocalcin (d-OC) of high purity. Nevertheless, this technique has its limitations, and the length of the $O C$ molecule (49 amino acids) is approximately the maximum which can be routinely synthesized. In this thesis we have chosen to study the substrate properties of osteocalcin using both organically synthesized $O C$ and d-OC. Once the proper protocol has been selected to produce sufficient amounts of d-OC, carboxylase from various tissue types can be used to study the properties of $d-O C$ and other substrates. Furthermore the isolation of carboxylase in the form of washed microsomes from various types of tissue, and its use in enzyme substrate interactions is described here.

\section{Chapter 3}

One of the high affinity substrates used in carboxylase research is ProlX-59 Q/S. ProlX59 Q/S consists of the propeptide covalently attached to the descarboxy Gla-domain of factor IX, and functions as a good substrate for carboxylase. The interactions of the propeptide and the Gla-domain is studied using purified bovine carboxylase. The importance of the propeptide for the carboxylation of the glutamate residues in the factor IX Gla-domain, the effect of the propeptide on the carboxylation of a non-Gladomain sequence containing $5 \mathrm{Glu}$ residues, and the substrate properties of synthetic 
d-OC for purified bovine carboxylase is described in this chapter. From the results reported in this chapter we can draw several conclusions:(i) the affinity of the carboxylase substrate and processivity is induced by the propeptide without requiring the conserved Gla-domain sequences and (ii) factor $\mathrm{DX}$ and osteocallin may have distinct mechanisms of interaction with the carboxylase.

\section{Chapter 4}

Since the results described in chapter 3 were obtained using purified carboxylase from bovine liver containing at least $2 \mu \mathrm{M}$ propeptide a new protocol for the production of carboxylase was developed. For this aim we have collaborated with the group of Prof. Dr. Stafford (Department of Biology, The University of Norh Carolina at Chapell Hill, U.S.A), who cloned the cDNA sequence of human $\gamma$-glutamyl carboxylase and expressed it in an insect cell line, normally free of carboxylase. The carboxylase purified from these cells was completely free of any interfering propeptide or propeptide containing substrates (endogenous substrate). Therefore the purified recombinant human carboxylase is the system of choice to study enzyme / substrate interactions Where the absence of a propeptide is required (e.g. d-OC).

Although the unique properties of $\mathrm{d}-\mathrm{OC}$ already have been discussed in chapters 2 and 3 , its characteristics are studied more extensively in this chapter. Chapter 4 describes the absence of inhibition by free propeptide of factor $I X\left(P r O^{F}\right)$ on $d-O C$, whereas Pro ${ }^{F x}$ strongly inhibits ProlX-59 Q/S carboxylation. Furthermore d-OC carboxylation is not stimulated by Pro ${ }^{F x}$ in contrast to bEELOMe. Pro ${ }^{F X}$ lowers the $K_{m}$ of short pentapeptide substrates 10 fold. The propeptide of osteocalcin $\left(\mathrm{Pro}^{\circ}\right)$ was incapable of either inhibiting ProlX-59 Q/S and d-OC carboxylation. Moreover Pro ${ }^{\circ}$ could not stimulate bEELOMle carboxylation, nor could it lower the $K_{\mathrm{m}}$ of bEELOMe. Synthetic carboxylated osteocalcin (OC) inhibited both $\mathrm{d}-\mathrm{OC}$ and bEELOMe, whereas it was incapable of inhibiting ProlX-59 Q/S carboxylation. These results implicate that Pro ${ }^{\circ}$ does not contribute to the high affinity carboxylase binding of the osteocalcin precursor molecule and that $\mathrm{d}-\mathrm{OC}$ binds carboxylase at a site distinct from the propeptide binding site. However, it remains unclear whether $\mathrm{d}-\mathrm{OC}$ binds to the active site, or on a distinct 
osteocalcin binding site on carboxylase.

\section{Chapter 5}

In this chapter definite proof is given that $d-O C$ binds carboxylase with high affinity on a specific $d-O C$ binding domain. By using a stereospecific active site inhibitor (S MeTPT) for carboxylase we have shown that bEELOMe is competitively inhibited by $S$ -MeTPT. ProlX-59 Q/S is competitively inhibited by Pro ${ }^{\mathrm{Fix}}$, since ProlX-59 Q/S initially binds the propeptide binding site on carboxylase prior to its carboxylation. Addition of $S$-MeTPT to ProlX-59 Q/S carboxylation resulted in a non-competitive inhibition of ProlX-59 Q/S. This is in agreement with the proposed mechanism by which ProlX-59 Q/S interacts with carboxylase. Since d-OC is inhibited by neither Pro ${ }^{\text {Fix }}$ nor Pro ${ }^{\circ C}$ it was expected that $\mathrm{d}-\mathrm{OC}$ would bind the active site on carboxylase and therefore competitively inhibited by $S$-MeTPT. However, addition of $S$-MeTPT to $d-O C$ carboxylation resulted in a non-competitive inhibition of $d-O C$. Since $d-O C$ lacks a propeptide these results give rise to postulate that carboxylase possesses a specific dOC binding domain, where $d-O C$ can bind with high affinity in a propeptide independent way.

\section{Chapter 6}

Here we describe the domain by which d-OC is capable of binding with high affinity to carboxylase. From other Gla-proteins it is known that the precursor proteins contain a high affinity propeptide at the $\mathrm{N}$-terminus, immediately adjacent to the Gla domain. Matrix Gla protein (MGP) is the only known Gla-protein to contain an internal propeptide which is homologous to the propeptide, but which is not removed from the protein after carboxylation. In the N-terminus of the d-OC molecule no homology can be found with the propeptide of either the other known Gla-proteins, or MGP. Nevertheless, we expected the thigh affinity carboxylase recognition sequence (CRS) of $d-O C$ to be located $\mathrm{N}$-terminally adjacent to the Gla-domain, between residues 1 and 16 . The Gladomain consists of residues 17 to 24 . We therefore generated warious d-OC peptides $d-O C^{1-25}, d-O C^{3-25}, d-O C^{5-25}, d-O C^{7-25}, d-O C^{10-25}$, and $d-O C^{13-25}$, all containing the 
non carboxylated Gla-domain, which may serve as a substrate in the in vitro carboxylase assay. The kinetic parameters of these peptides were compared with the intact $d-O C$ molecule. Due to the different $N$-terminal deletions it became evident that indeed substantial CRS activity is located between residues 1 and 13. Some of the residues proved to be particularly important, since deletion resulted in dramatic increases in the $K_{m}$ of the peptides. However, the $\mathrm{Km}$ of the $\mathrm{d}-\mathrm{OC}{ }^{1-25}$ still differed 10 fold when compared to the intact d-OC molecule. The efficiency of carboxylation was the highest for d-OC ${ }^{4-49}$, GST-rhOC $^{1-49}$ and GST-rhOC ${ }^{1-39}$ when compared to the short d-OC peptides, the propeptide-containing substrates or the short tri- and pentapeptides. Furthermore, a secondary structural component, located between residues 26 and 39 of the $d-O C$ molecule is also involved in the high affinity binding of osteocalcin to carboxylase, since this domain is capable of lowering the $\mathrm{K}_{\mathrm{m}}$ of $\mathrm{d} \sim \mathrm{OC} 10$ fold and increasing the efficiency of carboxylation -12 -fold.

Summarizing, the major findings presented in this thesis are (1) that the vitamin $K$ dependent carboxylase, besides the active site, possesses at least two substrate recognition domains. One recognition site is available for the "coagulation factor-type" Gla-proteins, the other site is essential for "OC-type" substrates. The first site recognizes propeptides, the latter recognizes a sequence present on $O C$ which has not been defined previously.

(II) Closer analysis of the sequence composition revealed that the carboxylase recognition sequence on $\mathrm{d}-\mathrm{OC}$ is composed of two units. The first unit consists of residues $1-13$ (N-terminal of the Gla-domain), and the second unit is composed of residues 26-39 (C-terminal of the Gla-domain). The fact that a carboxylase recognition site exists which is composed of two segments, devided by a Gla-domain, is new.

(III) The efficiency of $d-O C$ carboxylation is the highest when compared to propeptide-containing substrates and short pentapeptides.

(IV) In wivo, the precursor molecule of osteccalcin is synthesized containing a propeptide. Nonetheless, this propeptide has no measurable affinity for carboxylase. Therefore, the function of the osteocalcin propeptide remains unclear. It is possible that 
the osteocalcin propeptide is required for a more efficient utilization of $\mathrm{KH}_{2}$, by lowering its $K_{\mathrm{m}}$.

\section{Discussion}

Recombinant synthesis of descarboxy osteocalcin in $E$. coli, either with or without an attached propeptide has turned out to be more difficult than was expected. A single explanation for the low expression levels we obtained cannot be given. What remains is that only very few groups in the world have succeeded in producing low amounts of bacterially synthesized osteocalcin. The fact that bovine decarboxylated osteocalcin (bd-OC) already displayed unique substrate properties was one of the main reasons to start our line of investigations. Our experimental data from organically synthesized human descarboxy osteocalcin (d-OC) have confirmed and founded the previous results; osteocalcin possesses unique properties as a substrate for carboxylase. Our experimental data have substantiated the previous results obtained with bd-OC in washed microsomes, the interpretation of which was difficult due to the fact both the substrate and the enzyme were from bovine origin and the properties could therefore be distinct from the human proteins. Besides that, the possible damaging of bd-OC by thermal decarboxylation could not be assessed. In the experiments described in this thesis we have used purified human recombinant carboxylase (chapters 4,5 and 6 ) as a source for carboxylase, free of contaminating and interfering propeptides or endogenous substrates, which makes our experimentall results more convincing. The results presented in this thesis have added new insights to the mechanism by which Gla proteins are able to bind carboxylase. What previously was unknown was that carboxylase has at least two high affinity binding sites for the Gla precursor proteins. Whether these two binding sites are the only ones present on carboxylase remains to be awaited, but might have considerable consequences for optimal synthesis of, for instance, recombinant Gla proteins in human eukaryotic cell lines, necessary for the treatment of hemophilia. However, a proper understanding of the structure and interactions between the Gla precursor proteins and carboxylase is required to obtain maximal efficient production and carboxylation. 
The recent discovery of new Gla-proteins like the carboxylase itself, or proteins that are not involved in blood coagulation but in cellular growth (Gas-6), and other yet unknowin processes (the putative PRGP 1 and PRGP 2) indicates that the discovery of other new Gla-proteins is likely ${ }^{12}$. The type of interaction between the yet undiscovered Gla-proteins interact with carboxylase might be, like osteocalcin, in a propeptide independent way. This can be illustrated using a hypothetical calculation; It is expected that the human genome contains 100.000 genes. From these genes, $30 \%$ is known, which results in 30.000 proteins that have been currently discovered. If the known 13 Gla-proteins represent $30 \%$ of the total amount of Gla-proteins, this means that there are still 30 Gla-proteins to be discovered. Of these 30 Gla-proteins, at least 2 proteins will bind carboxylase in a propeptide independent way. Maybe, this could indicate that carboxylase is a much more versatile enzyme as was expected, capable of binding various types of proteins.

The role of Gla as a Ca ${ }^{2 *}$ (or other divalent metal-ions) binding residue remains to be discussed. A large number of other proteins are very well capable of binding $\mathrm{Ca}^{2+}$ without the need for Gla. Osteonectin, a non-Gla basement membrane protein found in bone and platelets contains a glutamic acid-rich $\mathrm{Ca}^{2+}$ binding domain. Gas-6 for instance, functions as a ligand for different protein kinases which are involved in cellular growth regullation. A deletion mutant of Gas-6, lacking the Gla domain, is very well capable of binding to the extracellular domains of two cell adhesion moleculerelated tyrosine kinase receptors, Rse and Axl, and thereby activating phosphorylation ${ }^{*}$. Therefore the question remains what is the the function of the Gla residues within Gas6 or other (yet unknown) Gla-proteins. The vitamin K-dependent carboxylase itself is also a Gla-protein, which possesses 3 Gla residues 4 . The function and the location of these Gla residues is still unknown. Furthermore it is unclear whether carboxylase is capable of functioning without being carboxylated itself. Gla residues also have been discovered already in 1982 in hermatypic corals, but the origin of the Gla remained unclear $^{5}$. Gla-proteins have aliso been discovered in the venom duct of the predatory marine snail, Conus geographus ${ }^{6}$. This was the first invertebrate organism reported to possess the posttranslational carboxylation mechanism, which was thought to be 
restricted to rather specialized mammalian systems. The invertebrate Gla-protein. called conantokin $-G_{\text {i }}$ is a 17 amino acid peptide that inhibits the $N$-methyl-D-aspartate receptor, thereby paralyzing the fish and thus become prey for the fish-hunting snail. Besides conantokin-G there are at least two other conantokins that contain Glaw residues, namely conantokin- $T$ and conantokin- $R^{7,8}$. The conantokin precursor proteins contain a propeptide which binds Conus carboxylase with high affinity, but not the mammalian enzyme. This implies a difference in either the enzyme or the propeptide of the conantokin precursor proteins versus the mammalian propeptides. Whether d-OC is able to bind Conus carboxylase remains to be investigated, but this is very well possible, and might thus form additional evidence for human descent and evolution.

The importance of the newly discovered carboxylase recognition sequence is that it offers a possibility for substrates to be carboxylated at a significant distance from the N-terminus. Normally, in propeptide-containing substrates, carboxylation takes place within the first $40 \mathrm{~N}$-terminal amino acids. The chimeric osteocalcin molecules synthesized by Kâkönen et al. (chapter 6 , this thesis) showed that OC-type recognition can occur at any position within a larger protein. Using this knowledge it may be possible to search for new members of this class of Gla-proteins.

The results presented in this thesis will add to the understanding of the characteristics required in the mechanism of the high affinity association between the various Gla-precursor proteins, osteocalcin in particular, and the vitamin K-dependent v-glutamyl carboxylase:

\section{References}

1. Manfichetti, G. Brancolini, C. Avanzi, G. \& Schneider, C. The protein encoded by a growth arrest-specific gene (gas6) is a new member of the vitamin K-dependent proteins related to protein $S$, a negative coregulator in the blood coagulation cascade. Mol Cell Biol 13, 4976\%4985 (1993).

2. Kulman, J. D. Harris. J. E. Haldeman. B. A. \& Davie. E. W. Primary structure and tissue distribution of two novel proline rich gamma carboxyglutamic acid proteins. Proc Natl Acad Sci USA 94, 9058-9062 (1997).

3. Mark, M. R., Chen, J., Hammonds, R. G., Sadick, M. \& Godowsk, P. J. Characterization of Gas6, a member of the superfamily of G domain- containing proteins, as a ligand for Rse and Axt. J Blol Chem 271, 9725 $9789(1996)$.

4. Berkner. K. L. \& Pudlota; B. N. Vitamin K-dependent carboxylation of the carboxylase Proc Natl Acad Sci 
USA 95, 466-471 (1998).

5. Hamilton, S. E. et al. gamma-Carboxyglutamic acid in iwertebrates: its identification in hermatypic corals. Biochem Biophys Res Commun 108, 610-613 (1982).

6. Mcintosh, J. M., Olivera, B. M., Cruz, L. J. \& Gray, W. R. Gamma-carboxyglutamate in a neuroactive toxin. $\checkmark$ Biol Chem 259, 14343-14346 (1984).

7. Haack, J.A. et al, Conantokin-T. A gamma-carboxyglutarnate containing peptide with N-methyl-d-aspartate antagonist activity. J Biol Chem 265, 6025-6029 (1990).

8. White, H. S. et al. Conantokin-R. Soc Neurosci Abstr 23, 2164 (1997). 


\section{Samenvatting, conclusies en discussie}

\section{Hoodstuk 1}

Tijdens de in wivo synthese van eiwitten ondergaan deze een groot aantal posttranslationele modificaties alvorens ze hun functie goed kunnen uitoefenen. Deze bewerkte eiwitten zijn secretoir, zoals de Gla-eiwitten welke betrokken zijn bij bloedstollings of weefselmineralisatie processen. De carboxylering van specifieke glutaminezuur (Glu) residuen tot $\gamma$-carboxy glutaminezuur (Gla) is een van de posttranslationele modificaties die wordt uitgevoerd door het vitamine K-afhankelijke enzym $\gamma$-glutamyl carboxylase. Dit carboxyleringsproces is alleen mogelijk in de aanwezigheid vande cofactor vitamine $\mathrm{K}$ hydroquinon $\left(\mathrm{KH}_{2}\right)$. Tijdens de omzetting van Glu naar Gla wordt $\mathrm{KH}_{2}$ in een 1:1 verhouding geoxideerd tot vitamine $\mathrm{K} 2,3$ epoxide $(\mathrm{KO})$ via een intermediair vitamine $K$ alkoxide. KO wordt vervolgens in twee opeenvolgende stappen gereduceerd; eerst tot $\mathrm{K}$ door het enzym $\mathrm{KO}$-reductase en vervolgens tot $\mathrm{KH}_{2}$ door het enzym K-reductase. Als gevolg van dit "recycling" proces is de humane dagelijkse behoefte aan vitamine $K$ relatief gezien erg laag. De omzetting van Glu naar Gla is nodig voor de calcium-bindende eigenschappen van de Gla-eiwitten. Silechts een beperkt aantal van alle bekende eiwitten in de mens zijn Gla-eiwitten. Daarom is het noodzakelijk dat deze Gla-eiwitten zich onderscheiden van andere eiwitten zodat ze herkenbaar zijn voor thet vitamine K-afhankelijke carboxylase. Derhalve bezitten de voortoper vormen van de Gla-eiwitten een domein, het zogenaamde propeptide, dat hen in staat stelt met een hoge affiniteit te binden aan het carboxylase. Het doel van dit proefschrift was het verschaffen van inzicht in de determinanten die noodzakelijk zijn voor de herkenning van de Gla-voorloper eiwitten door het carboxylase. Daarvoor is er besloten gebruik te maken van substraten afgeleid van het bot Gla-eiwit osteocalcine, van het voorlopereiwit van de humane bloedstollingsfactor IX, en van thet voorlopereiwit van humaan prothrombine. In dit hoofdstuk wordt een literatuuroverzicht gegeven van de ontdekking van vitamine $K$ in 1935 to het huidige kennisnivo en inzichten over het carboxylase, de cofactoren en substraten. Tevens worden de functies van de verschillende humane Gla-eiwitten besproken. 


\section{Hoofdstuk 2}

Het bot Gla-eiwit osteocalcine bezit een aantal unieke eigenschappen waardoor het in staat is om met een hoge affiniteit aan carboxylase te binden. Om voldoende van het osteocalcine te verkrijgen kunnen er verschillende methodes worden toegepast. De eerste mogelijkheid is om het natieve eiwit op te zuiveren uit (bovine/humane) botten. Aan deze techniek kleven echter een aantal nadelen; (i) het is een arbeidsintensieve methode met een lage opbrengst en in het geval van isolatie uit humane botten (ii) is de bron gelimiteerd en bestaat er een aanzienlijk infectierisico. Bovendien is het osteocalcine dat op deze wijze wordt gezuiverd reeds gecarboxyleerd, waardoor het niet bruikbaar is als in vitro substraat voor carboxylase. Thermische decarboxylering van natief osteocalcine kan worden toegepast maar zou ongewenste en onvoorspelbare schade kunnen induceren in het eiwit als gevolg van de reactieomstandigheden. Recombinant DNA technieken kunnen worden toegepast om ongelimiteerde hoeveelheden osteocalcine te produceren in bacteriën (Escherichia coli). Het door E. coli geproduceerde osteocalcine is niet gecarboxyleerd en kan daardoor worden gebruikt als in vitro substraat voor carboxylase. Naast de synthese van osteocalcine door $E$. coli is het ook mogelijk om zowel gecarboxyleerd osteocalcine (OC) als descarboxy-osteocalcine ( $d-O C$ ) in zuivere vorm te verkrijgen met behulp van chemische synthese. Niettemin heeft ook deze techniek zijn beperkingen en de lengte van het $O C$ molekuul ( 49 aminozuren) is ongeveer de maximum lengte die routinematig kan worden gesynthetiseerd. In dit proefschrift is ervoor gekozen om de substraateigenschappen van osteocalcine te bestuderen aan de hand van zowel organisch gesynthetiseerd $O C$ als d-OC. Indien het juiste protocol is gekozen om voldoende hoeveelheden d-OC te genereren, kan er carboxylase worden gebruikt dat afkomstig is uit verschillende weefseltypen, om zo de eigenschappen van d-OC en andere substraten te bestuderen. Bovendien wordt de isolatie van het carboxylase ult verschillende weefseltypen in de vorm van gewassen microsomen en het gebruik hiervan bij enzym/substraat interacties in dit hoofdstuk beschreven. 


\section{Hoofdstuk 3}

Een van de substraten die wordt gebruikt in het carboxylase onderzoek is ProlX-59 Q/S. Dit is een recombinant eiwit dat is afgeleid van de voorloper van het humane blcedstollingseiwit factor $\mathrm{X}$ dat bestaat uit het propeptide wat covalent gebonden zit aan het descarboxy Gla-domein en hierdoor een hoge affiniteit heeft voor carboxylase. De interacties van het propeptide met carboxylase zijn bestudeerd in gezuiverd bovine carboxylase. Het ontbreken van het propeptide en het effect hiervan op de substraateigenschappen van het descarbaxy Gla-domein van factor $I X$, het effect van het propeptide op de carboxylering van een non-Gla-domein sequentie met 5 Glu residuen en de substraateigenschappen van synthetisch d-OC voor het gezuiverde bovine carboxylase worden beschreven in dit hoofdstuk. Uit de resultaten die hierin zijn besproken kunnen een aantal conclusies worden getrokken: (i) de bindingsaffiniteit van het substraat voor het carboxylase en de processiviteit van deze reactie wordt geïnduceerd door het propeptide zonder de noodzaak van geconserveerde Gla-domein sequenties en (ii) factor $\mathrm{X}$ en osteocalcine hebben mogelijkerwijs verschillende interactiemechanismen met betrekking tot de carboxylasebinding.

\section{Hoofdstuk 4}

Aangezien de resultaten in hoofstuk 3 zijn verkregen met behulp van gezuiverd carboxylase afkomstig uit bowine lever dat minimaal $2 \mu \mathrm{M}$ propeptide bevatte, werd er een nieuw protocol voor de zuivering van carboxylase ontwikkeld. Hiervoor hebben we samengewerkt met de groep van Prof. Dr. Stafford (Department of Biology. The University of North Carolina at Chapel Hill, U.S.A.) die de CDNA sequentie van humaan $\gamma$-glutamyl carboxylase gecloneerd en tot expressie gebracht hebben in een insecten cellijn, die normaliter geen carboxylase bevat. Het carboxylase dat uit deze cellen werd opgezuiverd was volledif vrij van storend propeptide en/of propeptide bevattende substraten (endogeen substraat). Hierdoor vormt het het gezuiverde recombinante humane carboxylase het systeem bij uitstek om enzym/substraat interacties te meten waarbij de afwezigheid van propeptides gewenst is (bijv. d-OC).

Hoewel de unieke substraateigenschappen van d-OC reeds werden aangehaald in de 
hoofdtukken 2 en 3, worden de karakteristieken uitvoeriger besproken in dit hoofdstuk. in hoofdstuk 4 wordt de afwezigheid van remming door het vrije propeptide van factor IX $\left(\right.$ Pro $\left.^{\text {FXX }}\right)$ op d-OC beschreven terwijl Pro ${ }^{F \mid X}$ de carboxylering van ProlX-59 Q/S zeer sterk remt. Tevens wordt aangetoond dat d-OC carboxylering niet gestimuleerd wordt door Pro ${ }^{\mathrm{Fx}}$, dit in tegenstelling tot bEELOMe, dat wel wordt gestimuleerd door Pro ${ }^{\mathrm{Fix}}$. Pro Fix verlaagt de $K_{m}$ van korte penta-peptiden met een factor 10. Het propeptide van osteocalcine (Pro ${ }^{\circ}$ ) was niet in staat om de carboxylering van zowel ProlX-59 Q/S als $d-O C$ te remmen. Bovendien was Pro ${ }^{\circ 0}$ niet in staat om de carboxylering van bEELOMe te stimuleren of de $K_{t m}$ van bEELOMe te verlagen. Synthetisch gecarboxyleerd osteocalcine (OC) inhibeerde zowel de d-OC als de bEELOMe carboxylering, terwijl het niet in staat bleek de ProlX-59 Q/S carboxylering te remmen. Deze resultaten houden in dat $P r{ }^{\circ C}$ niets bijdraagt aan de hoge affiniteit dat het osteocalcine voorlopereiwit heeft voor carboxylase en dat d-OC aan het carboxylase bindt op een plaats die afwijkt van de propeptide bindingsplaats. Uit deze resultaten bijkt echter nog niet of d-OC op het katalytisch domein bindt of op een specifieke osteocalcine bindingsplaats op het carboxylase.

\section{Hoofdstuk 5}

In dit hoofdstuk wordt het definitieve bewijs geleverd dat d-OC het carboxylase bindt met een hoge affiniteit op een specifiek osteocalcine bindend domein. Door gebruik te maken van een specifieke katalytisch domein remmer (S-MeTPT) voor carboxylase hebben we aan kunnen tonen dat bEELOMe competitief wordt geremd door S-MeTPT. ProlX-59 Q/S wordt competitief geremd door Pro ${ }^{\mathrm{FiX}}$, aangezien ProlX-59 Q/S allereerst bindt op de propeptide bindingsplaats op carboxylase om vervolgens te worden gecarboxyleerd. Toevoeging van S-MeTPT aan ProlX-59 Q/S carboxylering resulteerde in een non-competitieve inhibitie van ProlX-59 Q/S. Dit is in overeenstemming met het voorgestelde mechanisme volgens welk ProlX-59 Q/S interageert met carboxylase. Aangezien d-OC carboxylering niet werd geremd door zowel Pro ${ }^{\mathrm{Fx}}$ als $\mathrm{Pro}^{\circ \mathrm{CC}}$ werd verondersteld dat $d-O C$ op het katalytisch domein van carboxylase zou binden en dus competitief geremd zou worden door S-MeTPT. Dit bleek echter niet het geval te zijn. 
Toevoeging van S-MeTPT aan d-OC carboxylering resulteerde in een non-competitieve remming van d-OC. Omdat d-OC géén propeptide bezit mag de stelling geponeerd worden dat carboxylase naast een propeptide bindingsplaats ook over een specifieke osteocalcine bindingsplaats beschikt waar osteocalcine op een propeptideonafhankelijke manier kan binden.

\section{Hoofdstuk 6}

In dit hoofdstuk beschrijven wij het domein waarmee d-OC met hoge affiniteit bindt aan carboxylase. Dankzij andere Gla-eiwitten is het duidelijk geworden dat voorlopereiwitten over een propeptide beschikken dat zich $\mathrm{N}$-terminaal naast thet Gladomein bevindt. Matrix Gla-proteïne (MGP) beschikt als enige Gla-eiwit over een intern propeptide dat homoloog is aan de bekende propeptides, maar wat niet wordt afgesplitst van het eiwit nadat dit is gecarboxyleerd. In de $\mathrm{N}$-terminus van het d-OC molecuul kan géén homologie worden gevonden met de propeptides van de andere Gla-eiwitten noch met het interne propeptide van MGP. Niettemin veronderstelden we dat de herkenningssequentie voor het carboxylase (CRS) zich bevindt in de $\mathrm{N}$-terminus van d-OC, vóór het Gla-domein tussen residuen 1 en 16. Het Gla-domein van osteocalcine bestaat uit residuen 17-24. Daarom zijn er verschillende $d-O C$ peptiden gesynthetiseerd, te weten $d-O C^{1-25}, d-O C^{3-25}, d-O C^{5-25}, d-O C^{7-25}, d-O C^{10-25}$ en $d-O C{ }^{13-25}$, die allemaal het niet gecarboxyleerde Gla-domein bevatten zodat ze als substraat zouden kunnen dienen voor de in vitro carboxylase test. De kinetische parameters van deze peptiden werden vergeleken met het intacte $\mathrm{d}-\mathrm{OC}$ molecuul. Als gevolg van de verschillende $\mathrm{N}$-terminale deleties van de peptiden werd duidelijk dat de CRS zich voor het grootste gedeelte bevindt tussen residuen 1 en 13. Sommige aminozuren in dit domein bleken bijzonder belangrijk, aangezien deletie van een aantal residuen resulteerde in een verhoging van de $K_{m}$ van de peptides. Het verschil in $K_{m}$ tussen $d-O C{ }^{1.25}$ en $d-O C$ bedroeg echter nog altijd een factor 10. De carboxyleringsefficiency was het hoogst bij d-OC ${ }^{1-49}$ "GST-rhOC ${ }^{1.49}$ en GST-rhOC ${ }^{1-39}$ in vergelijking tot de korte d-OC peptiden, de propeptid-bevattende substraten of de korte tri- en penta-peptiden. Bovendien bleek een secundaire structurele component 
die gelegen is tussen residuen 26 en 39 van het intacte d-OC molekuul ook betrokken te zijn bij de hoge affiniteit van het osteocalcine molekuul voor carboxylase. Dit 26-39 domein bleek in staat om de $K_{m}$ van d-OC met een factor 10 te verlagen en de carboxylerimsefficiency met een factor 12 te verhogen.

Concluderend zijn de belangrijkste bevindingen in dit proefschrift (I) dat het vitamine Kafhankelijke carboxylase, naast het catalytisch domein, tenminste twee substraat herkenningsdomeinen bezit. Een herkenningsdomein is beschikbaar voor "stolfactortype" Gla-eiwitten, het andere domein is essentieel voor "OC-type" substraten. Het eerste domein herkent propeptides, het laatste domein herkent een sequentie aanwezig op d-OC, die nog niet eerder beschreven was.

(Ii) Nadere analyse van de sequentiesamenstelling toonde aan dat de carboxylase herkenningssequentie op d-OC uit twee gedeelten bestaat. Het eerste gedeelte bestaat uit de residuen 1-13 ( $\mathrm{N}$-terminaal van het Gla-domein) en het tweede gedeelte bevindt zich tussen de residuen 26-39 (C-terminaal van het Gla-domein). Het feit dat er een carboxylase herkenningssequentie uit twee delen bestaat die worden gescheiden door het Gla-domein is nieuw.

(III) De efficiency waarmee d-OC werd gecarboxyleerd was het hoogst wanneer vergeleken met propeptide-bevattende substraten en korte penta-peptiden.

(IV) In vivo wordt het voorloper molekuul van osteocalcine gesynthetiseerd met een propeptide. Niettemin heeft dit propeptide geen meetbare affiniteit voor carboxylase. Hierdoor blijft de functie van het osteocalcine propeptide onduidelijk. Het is mogelijk dat dit propeptide noodzakelijk is voor een efficienter gebruik van $\mathrm{KH}_{2}$, via een verlaging van de $K_{m}$ van deze cofactor.

\section{Discussie}

Recombinante synthese in $E$. coll van descarboxy osteocalcine al dan niet met een propeptide is moeilijker gebleken dan werd verondersteld. Een enkele verklaring voor het lage expressienivo van osteocalcine dat wij vonden is niet te geven. Een feit is echter dat slechts zéer weinig onderzoeksgroepen in de wereld er in geslaagd zijn 
kleine hoeveelheden bacterieel gesynthetiseerd osteocalcine te produceren. Aangezien gedecarboxyleerd bovine osteocalcine (bd-OC) al unieke substraateigenschappen vertoonde in het verleden was één van de redenen om onze onderzoekslijn te starten. Onze experimentele data, afkomstig van organisch gesynthetiseerd descarboxy osteocalcine $(\mathrm{d}-O C)$ hebben de al bekende resultaten bevestigd en verder gefundeerd: osteocalcine bezit een aantal unieke substraateigenschappen. Verder gefundeerd aangezien interpretatie van resultaten uit het verleden, verkregen met bd-OC in gewassen microsomen moeilijk was aangezien zowel het substraat ats het enzym van bovine oorsprong was, waardoor de eigenschappen zouden kunnen afwijken van de humane eiwitten. Bovendien was het niet mogelijk om beschadigingen aan het bd-OC als gevolg van de thermische decarboxylering vast te stellen. In de experimenten beschreven in dit proefschrift hebben we gebruik gemaakt van gezuiverd humaan recombinant carboxylase (hoofdstukken 4,5 en 6). Dit carboxylase is vrij van contaminerende en belemmerende propeptides of endogene substraten wat onze experimentele resultaten verder versterkt. De resultaten in dit proefschrift hebben nieuwe inzichten verschaft in de wijze waarop Gla-eiwitten in staat zijn aan carboxylase te binden. Wat voorheen onbekend was, is dat carboxylase over tenminste twee hoogaffiniteits bindingsplaatsen voor Gla-voorlopereiwitten beschikt. Of deze twee bindingsplaatsen de enigen zijn op carboxylase is nog onbekend, maar dit kan aanzienlijke consequenties hebben voor de optimale synthese van bijvoorbeeld recombinante Gla-eiwitten in eukaryote cellen, noodzakelijk voor de behandeling van hemofiliepatienten. Echter, een gedegen begrip van de structuur en de interacties van de Glameiwitten met het carboxylase zijn noodzakelijk om maximale en efficiënte synthese en carboxyleringsgraad te verkrijgen.

De recente ontdekking van nieuwe Gla-eiwitten waaronder het carboxylase zelf, of Gla-eiwitten die zijn betrokken celgroei (Gas-6) of bij nog onbekende processen (PRGP-1 en PRGP-2) geeft aan dat de ontdekking van nieuwe Gla-eiwitten niet uit te sluiten is ${ }^{1,2}$. De wijze van interactie tussen deze nog te ontdekken Gla-eiwitten en het carboxylase zou, net als osteocalcine, kunnen plaatsvinden op een propeptide onafhankelijke wijze. Dit kan worden geillustreerd met het volgende hypothetische 
rekenvoorbeeld; Men vermoedt dat het menselijke genoom uit circa 100.000 gegen bestaat. Hiervan is $30 \%$ inmiddeis bekend, wat overeenkomt met 30.000 verschillende eiwitten. Indien de nu 13 bekende Gla-eiwitten $30 \%$ vertegenwoordigen van het totale aantal Gla-eiwitten houd dit in dat er nog 26 Gla-eiwitten kunnen worden ontdekt. Van deze 26 Gla-eiwitten zullen ten minste 2 eiwitten het carboxylase binden zonder de noodzaak van een propeptide. Dit houdt in dat carboxylase een veelzijdig enzym is dat in staat is om verschillende typen eiwitten te binden.

De rol van Gla als $\mathrm{Ca}^{2+}$ (of andere divalente metaal-ionen) bindend aminozuur blijft discutabel. Er bestaan veel eiwitten die zeer goed in staat zijn om $\mathrm{Ca}^{2+4}$ te binden zonder de noodzaak van Gla-residuen. Osteonectine, een non-Gla basaal membraaneiwit afkomstig uit bot en bloedplaatjesbevat een glutaminezuurrijk $\mathrm{Ca}^{2+}$ bindend domein. Gas-6 bijvoorbeeld, fungeert als een ligand voor verscheidene proteine kinasen die betrokken zijn bij cellulaire groeiregulatie. Een deletiemutant van Gas-6, waarvan het volledige Gla-domein ontbreekt, is zeer goed in staat om aan de extracellulaire domeinen van twee celadhesie-molecuul gerelateerde tyrosine kinase receptoren Rse en Axl te binden en zo de fosforylering te activeren ${ }^{3}$ Hierdoor blijft onduidelijk wat de functie van de Gla-residuen in Gas-6 of andere (nog onbekende) Gla-eiwitten is. Het vitamine K-afhankelijke carboxylase zelf is eveneens een Gla-eiwit, met 3 Gla-residuen ${ }^{4}$. De functie en de positie van deze Gla-residuen in het carboxylase molecuul zijn nog niet bekend. Bovendien is het nog niet bekend of carboxylase wel in staat is te functioneren zonder Gla-residuen. Gla residuen zijn ook al in 1982 ontdekt in hermatypische koralen, maar de herkomst van dit Gla bleef onbekend ". Er zijn tevens Gla-eiwitten ontdekt in de gifklieren van de roof-zeeslak Conus geographus ${ }^{6}$. Dit was het eerste en voorlopig enige ongewervelde organisme waarvan bekend werd dat het posttranslationeel carboxyleerde. Tot dan toe werd aangenomen dat carboxylering uitsluitend was voorbehouden aan gespecialiseerde zoogdiersystemen. Het Conus Gla-eiwit, conantokine-G genaamd, is een peptide met een lengte van 17 aminozuren met daarin 5 Gla-residuen. Het conantokine-G remt de N-methyl-Daspartaat receptor "waardoor vissen worden verlamd en zo een gemakkelijke prooi vormen voor de op wis jagende zeeslak. Naast conantokine-G zijn er tenminste 2 
andere Gla-residu bevattende conantokines bekend, namelijk conantokine-T en conantokine- $R{ }^{p, 8}$. De voorlopereiwitten van de conantokines bezitten eveneens een propeptide dat met grote affiniteit bindt aan het Conuscarboxylase, maar niet aan zoogdiercarboxylase. Dit houdt in dat er verschillen bestaan in het enzym of het Conus propeptide versus de zoogdierpropeptiden. Of het $d-O C$ in staat is om met hoge affiniteit te binden aan het Conuscarboxylase dient nog onderzocht te worden, maar zou zeer wel mogelijk kunnen zijn. Dit zou additioneel bewijs kunnen vormen voor de evolutionaire overgang van ongewervelde naar gewervelde dieren en zo een aanvulling kunnen zijn voor de theorieën omtrent de evolutie van de mens.

Het belang van de nieuw ontdekte carboxylase herkenningssequentie is dat het voor substraten de mogelijheid biedt om carboxylering plaats te laten vinden op een significante afstand van de $\mathrm{N}$-terminus. Normaliter windt de carboxylering van propeptide-bevattende substraten plaats binnen de eerste $40 \mathrm{~N}$-terminale aminozuren. Dankzij de door Käkỏnen et al. gesynthetiseerde chimere osteocalcine moleculen is aangetoond dat carboxylering op iedere plaats in een groot eiwit mogelijk is (hoofdstuk 6). Met deze kennis is het wellicht mogelijk om nieuwe leden van deze klasse van Glaeiwitten op te sporen.

De resultaten welke zijn beschreven in dit proefschrift zullen ertoe bijdragen dat de eigenschappen welke noodzakelijk zijn in het mechanisme van de hoge-affiniteits associatie tussen de verschillende Gla-eiwitten, met name osteocalcine, en het vitamine K-afhankelijke $\mathrm{v}$-glutamyl carboxylase beter begrepen worden.

\section{Referenties}

1. Manfiolati, G. Brancolini, C. Avanzi, G. \& Schneider, C. The protein encoded by a growth arrest-specific gene (gas6) is a new member of the vitamin K-dependent proteins related to protein $S$, a negative coregulator in the blood coagulation cascade. Mol Call Biol 13, 4976-4985 (1993).

2. Kulman, u. D. Harris, J. E, Haldeman, B. A. B Davia, E. W. Primary structure and tissue distribution of two novel proline rich gamma carboxyglutamic acid proteins. Proc Nati Acad Sci USA 94, 9058-9062 (1997)

3. Mark, M. R., Chen, J. Hammonds, R. G. Sadick, M. \&. Godowsk, P. J Characterization of Gas6, a member of the superfamily of G domain- containing proteins, as alligand for Rise and Axd. $J$ Biol Chem 271, 9785$9789(1996)$

4.

Berkner, K. L. \& Pudota, B. N. Vitamin K-dependent carboxylation of the carboxylase. Proc Natl Acad Sct 
USA $95,466-471(1998)$.

5. Hamilton، S. E. et al. gamma-Carboxyglutamic acid in invertebrates: its identification in hermatypic corals. Biochem Biophys Res Comumun 108: 610-613 (1982).

6. Mclintosh, J. M., Olivera, B. M., Cruz, L. J. \& Gray, W. R. Gamna-carbaxyglutamate in a neiuroactive toxin. $J$ Biol Chem 259, 14343-14346 (1984).

7. Haack. J. A. et al. Conantokin-T. A gamma-Carboxyglutamate containing peptide with $N$-intethyl-d-aspartate antagonist activity. J Biol Chem 265, 6025-6029 (1990).

8. White, H. S. el al. Conantokin-R. Soc Neurosci Abstr 23, 2164 (1997). 


\section{Curriculum Vitae}

De auteur van dit proefschrift werd op 3 augustus 1968 geboren te Goille. Na een kortstondig verblijf in Tilburg verhuisde hij naar Vught. Hier werd basisschoof "De Baarzen" doorlopen, waarbij het eindrapport van de $6^{6}$ klas aanleiding gaf om in 1980 zijn middelbare schoolcarrière te starten aan het "Maurick College", eveneens gevestigd te Vught. De brugklas bleek toch lastiger dan verwacht, zodat na de nodige taken gedurende de zomervakantie, werd gepoogd het HAVO met goed gevolg af te leggen. in 1986 werd dit diploma behaald, waarna het WWO de volgende uitdaging vormde.

In 1988 werd ook dit met goed gevolg afgelegd, zodat Roger eindelijk in Maastricht kon gaan studeren aan wat toen nog de Rijksuniversiteit Limburg was. Gezondheidswetenschappen bleek bij nader inzien een zeer goed alternatief te vormen voor Geneeskunde, en met name de afstudeerrichting "Biologische Gezondheidkunde" waarbinnen het biomedische wetenschappelijk onderzoek een prominente rol speelde, had zijn warme belangstelling. In december 1992 werd begonnen met de afstudeerstage bij de vakgroep Moleculaire Celbiologie en Genetica, aan de faculteit der Geneeskunde, eveneens in Maastricht. Hier werd door Dr. Guillaume van Eys en Dr. Rob Slobbe getracht Roger te bekwamen in de recombinant DNA-technologie.

In oktober 1993 werd Roger benaderd door Dr. Cees Vermeer en Dr. Berry Soute (vakgroep Biochemie, faculteit der Geneeskunde te Maastricht) om als studentassistent de recombinant DNA-technologie te implementeren binnen de divisie vitamine K. In juli 1994 werd de doctoraalbul Gezondheidswetenschappen behaald, waarna hij in september 1994, gevrijwaard van militaire dienst, assistent in opleiding werd bij de divisie vitamine K (Dr. C. Vermeer,vakgroep Biochemie, faculteit der Geneeskunde to Maastricht). Gedurende deze periode heeft hij in november 1995 twee weken fermentatieonderzoek gedaan bij Dr. Robert Azerad (Laboratoire de Chimie et Biochimie Pharmacologíques et Toxicologiques Université R. Descartes, Paris, France) en heeft hij gedurende de maanden mei en juni 1998 onderzoek gedaan in het laboratorium van Prof. Dr. Darrel W. Stafford, (Department of Biology, The University of North Carolina at Chapel Hill, USA). De resultaten van het vierjarig promotieonderzoek staan beschreven in dit proefschrift.

Roger is getrouwd met Jacqui, woonachtig te Amersfoort en thans werkzaam als medical advisor bij Excerpta Medica Medical Communications te Almere-Stad. 


\section{Bedankt / Thanks / Merci}

Alhoewel de kaft en titelpagina doen vermoeden dat ik al het onderzoek, waarvan de resultatem in dit boekje staan beschreven, helemaal in mijn eentje heb uitgevoerd, is het tegendeel waar. Een proefschrift schrijf je nooit alleen en zeker niet dit exemplaar.

Allereerst wil ik mijn beide promotores Prof. Dr. H.C. Hemker en Prof. Dr. F.C.S. Ramaekers bedanken; beste Coen en Frans, bedankt voor het vertrouwen door jullie in mij gesteld en het verlenen van de nodige vrijheid bij het tot stand komen van dit proefschrift.

Dr. C. Vermeer, beste Kees. Gek eigenlijk om jouw voornaam met een $\mathrm{K}$ te schrijven, ik ben na 5 jaar behoorlijk aan die $C$ gaan wennen. Jij benaderde mij 6 jaar geleden om student assistent bij jullie te worden en me bezig te gaan houden met kloneerwerk. De jonge hond die toen voor je stond, blakend van het zelfvertrouwen en niet gehinderd door enige vorm van zelfonderschatting zou dat klusje bij jou op het lab wel even gaan klaren. Ondanks dat het klusje niet geheel volgens verwachting verliep besloot je toch om mil als A.I.O. in dienst te nemen. Het is uiteindelijk toch nog goed gekomen, maar alleen dankzij jouw inzicht, overzicht, accuratesse, inzet en ideeën. Je bent nu directeur van je eigen BV-tje en dat zat er eigenlijk ook wel altijd in, want je bent ook wel een beetje een zakenmannetje (en op de centen), met al die contracten die je binnensleepte. Dankzij deze contracten konden er een hoop dingen gerealiseerd worden waar ik van profiteerde ondlanks dat de contracten niet voor mijn onderzoek bedoeld waren. Kees, bedankt !

Dr. B.A.M. Soute, beste Berry. Als wij samen over de gang liepen leek het net wat en 1/2-wat, waarbij ik in het midden laat wie weike rol vervulde. Wat heb ik ongelooflijk veel mazzel gehad om jou als begeleider te hebben. Jij hebt me wegwijs gemaakt in de carboxylasewereld, en niet alleen dat. Dankzij jou heb ik ook de juiste mensen binnen de universiteit leren kennen. Jouw voorliefde voor wijn en lamsvlees werkte erg aanstekelijk en ik zal de BBQ's bij jou en Anneke thuis erg missen. Op praktisch gebied weet je (bijna) alles en dankzij jouw hobby heeft bijna iedereen die ik ken een B\&M thuis staan. Door die hobby was het soms wel moeilijk om je te spreken. 
De beide periodes die wij samen in het buitenland hebben doorgebracht heb ik als enorm prettig ervaren, en waren daarom ook nooit vervelend. We hebben vaak discussies gevoerd en dan bleek maar al te vaak dat je niet te snel mensen moet beoordelen op grond van wat anderen over die persoon vertellen. Je eigen indruk is nog altijd de beste. Berry, het ga je goed.

Leon, wij zijn ongeveer tegelijkertijd begonnen en wilden allebei dolgraag onder militaire dienst uit. Jij koos de wel een erg drastische oplossing, je besloot namelijk te trouwen met Romy. Ikzelf probeerde het op onmisbaarheid voor het onderzoek te gooien en ook dat lukte. Jij en Romy hebben inmiddels een dochtertje, dus heb je uiteindelijk de juiste keuze gemaakt. Leon, jij was een hele prettige collega met een aanstekelijke vette lach en een geweldig gevoel voor humor, vooral als je de avond van tevoren voetbaltraining had gehad. Jouw spontane manier van mensen benaderen gecombineerd met inzicht en motivatie zal ervoor zorgen dat we in de toekomst nog veel van je zullen horen.

Paul, het oermens. Gij mee oew brabantse humor, ook al ben je van origine geen brabander. Jij bent door een hele donkere periode gegaan na het overlijden van Yvette. De wijze waarop jij je hebt teruggevochten uit dit dal boezemde bij mij enorm veel ontzag in. Je reist iedere dag vanuit Eindhoven met de trein op en neer, in je vrije tijd mountainbike je, klim je wat en trek je zo af en door de wildernis van Canada. Vooral om dat laatste benijd ik je zeer. Je hebt de zaken goed voor elkaar en bent een keiharde worker al ben je af en toe wel erg eigenwijs. Niet voor niets is er nu een MGPtestkit. Respect Paul, respect.

Lavienja, Fieneke, onze epidemiologe, met al die lastige proefpersonen die af en toe het bloed onder je nagels vandaan halen. Jij hebt je vol overgave gestort op een groot project waarvoor je ook nog de nodige fysische technieken onder de knie moest zien te krijgen. Gelukkig kun je alle problemen die gepaard gaan met patientgebonden research bespreken met Cyril, want die heeft ook besloten om A.I.O. to worden. Waarom nou? Ik heb veel met je kunnen lachen en het verbaasde me telkens weer hoe jii in staat bleek om die enorme hoeveetheden vlaai in dat ranke lichaam van je te proppen. Ik kan met een gerust hart het senior AIO-schap aan jou overlaten. Loat diech neet begöschelle! 
Henry, beste Sprokkel. Na de nodige omwegen via het M.L.O., H.L.O. en Universiteit was jij dan de eerste echte moleculair bioloog die als A.I.O. de vitarmine K divisie kwam versterken. Ondanks je kwaaltje heb je besloten om de consequenties van die keuze te aanvaarden. Dat is een hele moeilijke keuze geweest, maar hel feit dat je toch hebt gedaan zegt genoeg over je doorzettingsvermogen. Je bent echt een hele slimme moleculair bioloog en dankzij jou impulsen is er "poeier in een potje" gekomen. Zorg ervoor dat je een beetje lief blijft tegen Fien, want je kunt af en toe wel erg bot zijn.

Birgit en Marjo, de 2 dames van het lab. Ondanks dat we elkaar in de loop der tijd, door de komst van in totaal 4 kinderen, minder zagen heb ik preftig met jullie samengewerkt. Ik blijf het knap vinden hoe jullie een baan kunnen combineren met het grootbrengen van kinderen (Voordat ik andere moeders tegen de schenen schop; dit geldt natuurlijk voor alle werkende moeders 1$)$.

Hierbij will ik eveneens mijn oud collega's Monique Groenen en Judy Wolf, ondanks dat ze alweer een hele tijd elders werken, bedanken voor de zeer goede en gezellige samerwerking.

Mijn huidige collega AlO's van de vakgroep Biochemie; Dave, Marjan, Joyce, Lico, Irene S, Jacco, Irene $K$, Ra"ed, Ruth, Harold, Cecile wil ik bedanken voor de goede sfeer op het lab en daarbuiten. Beloof me dat jullie als die-hards in Houthalen het licht in de bar uit blijven doen. Die traditie moet in ere worden gehouden!

De inmiddels tot doctor gepromoveerde oud collega AlO's; Asiong, Jacintha . Edgar, Gerry, Dirk, Didier, Rachana, Mark Anton en Arthur wil ik hierbij dank zeggen voor de goede sfeer en het slappe ge......

Verder wil ik Mariet en Trees bedanken voor de secretariële ondersteuning, bemoedering en de gezelligheid.

Alle overige collega"s van de vakgroep Biochemie bedankt "

Guillaume van Eys en Rob Slobbe die bij mij de interesse voor wetenschappelijk onderzoek hebben aangewakkerd wil ik hiervoor bedanken. Beste Guillaume, wi] hebben elkaar de afgelopen 5 jaar veel te weinig gezien en dat geldt nog meer voor Rob. Ik vrees echter dat het er niet beter op wordt, hoe jammer ik dit ook vind. Tevens will ik hierbij alle (oud)collega's van de vakgroep Moleculaire Celbiologie \& Genetica bedanken voor de gezelligheid voor zowel op thab als daarbuiten. 
Bovendien will ik de kerells van de centrale glas- en sterilisatieafdeling bedanken voor het zonder mokken wegwerken van enorme hoeveelheden stinkende bacterieprut en vuil glaswerk, en die bovendien nooit verlegen zaten om een praatje. Gerry, Chris, Michel en Arno, bedaaaaaaaaaaaaaaank.

I would like to use this opportunity to express my thanks to Prof. Dr. D.W. Stafford. Dear Darrel, you and Sheue-Meil are excellent hosts and you made my two months stay in Chapel Hill really enjoyable. Your insect-cell carboxylase is really good stuff! I felt deeply honoured to publish together with you and your co-workers. Many thanks to both of you for accepting the position in the corona. Furthermore I would like to thank all the people at the Staffordlab for their patience and hospitality. Thanks Tom, Vasantha, Dayun, Pen-Jen, Tong, Jack, Jin-Li, Jian-Ping, David, Tao, Shannon and Leigh.

J'aimerai aussie remercier Dr. R. Azerad, pour son aimable invitation à entreprendre un travail de recherche dans son laboratoire. Cher Robert, grâce a vous et votre équipe mon passage à Paris fut un vrai plaisir. De plus, le travail effectué et la synthèse, par vos chercheurs, de l'inhibiteur, fut de première importance dans la suite de nos investigations. Enfin, je n'oublierai pas de sitôt les agreables repas, en votre compagnie, près du boulevard Saint Germain. Merci pour tout....

Dr. Paul Proost (Moleculaire Immunologie, Katholieke Universiteit Leuven) en Dr. Hob Ebberink van Perkin-Elmer B.V. (Nieuwerkerk a/d IJssel, Nederland) wil ik. bedanken voor het respectievelijk synthetiseren en beschikbaar stellen van de astronomische hoeveelheden van zowel gecarboxyleerd-als descarboxy-osteocalcine. Zonder deze peptides was mijn onderzoek nooit zover gevorderd. Bedankt.

Dr. D.T.S. Rijkers, beste Dirk, voor jou geldt dat een verre vriend beter is dan helemaal geen peptides. Il ben je veel dank verschuldigd voor het bepalen van de massas van beide "osteocaline" peptides en het belangeloos synthetiseren van de velle "korte" osteocalcine peptides. 
De leden van de beoordelingscommissie wil ik danken woor het kritisch reviseren van dit proefschrift.

Mijn twee paranimfen Ruben Verheul en Erwin Houben wil ik hierbij bedanken voor hun inzet en morele ondersteuning.

Tot zover de professionele inbreng. Het is echter onmogelik om een proefschrift te realiseren zonder steun en inbreng van de privésector.

Allereerst wil ik mijn ouders bedanken. Dankzij hun ben ik geworden tot wat ik nu ben. Hun steun en vertrouwen zijn onmisbaar gebleken.

Mijn broer Erwin. Mr. Houben, je was stiekum mijn grote voorbeeld. Alleen jij kon zoveel energie steken in je studie. Jij bent het woorbeeld dat niets onmogelijk is, als je maar wilt.

Tenslotte wil ik mijn lief Jacqui bedanken. Lieve Sjakie, normaal staan hier van die zinnen als; will je dan eindelijk met me.... enz. Dat hoeft niet meer, want inmiddels zijn we al weer een poosje getrouwd. Wat gaat de tijd toch snel, om dan toch maar een cliché te gebruiken. Ik wil jou bedanken voor het feit dat je nu al 7 jaar mijn vriendinnetje bent en dat we nog maar lang samen mogen zijn.

Mocht ik, ondanks dit uitvoerige dankwoord, dan toch nog iemand vergeten zijn;

\section{BEDANKT HE !}

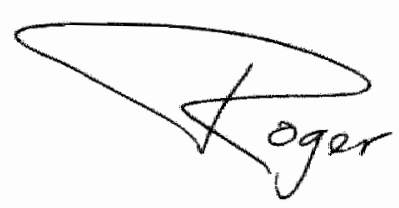

